\title{
The Dalradian rocks of the central Grampian Highlands of Scotland
}

\author{
J.E. Treagus, P.W.G. Tanner, P.R. Thomas, R.A. Scott and D. \\ Stephenson
}

Jack E. Treagus 15 Raynham Avenue, Didsbury, Manchester M20 6BW; formerly Department of Earth Sciences, University of Manchester. P.W. Geoff Tanner Department of Geographical and Earth Sciences, University of Glasgow, Gregory Building, Lilybank Gardens, Glasgow G12 8QQ.

Peter R. Thomas (deceased) formerly Department of Civil Engineering, Paisley College of Technology.

Robert A. Scott Cambridge Arctic Shelf Programme, West Building, 181 a Huntingdon Road, Cambridge CB3 ODH.

* David Stephenson British Geological Survey, Murchison House, West Mains Road, Edinburgh EH9 3LA.

dstabgs.ac.uk

$0131650 \quad 0323$

* Corresponding author

Keywords:

Geological Conservation Review

Central Grampian Highlands

Dalradian Supergroup

Lithostratigraphy

Structural Geology

Metamorphism

\begin{abstract}
The Central Grampian Highlands, as defined here, are bounded to the north-west by the Great Glen Fault, to the south-west by Loch Etive and the Pass of Brander Fault and to the south-east by the main outcrop of the Loch Tay Limestone Formation. The more arbitrary northern boundary runs north-west along the A9 road and westwards to Fort William. The detailed stratigraphy of the Dalradian Supergroup ranges from the uppermost Grampian Group through to the top of the Argyll Group, most notably seen in the two classic areas of Loch Leven-Appin and Schiehallion-Loch Tay; Southern Highland Group strata are preserved only in a small structural inlier south of Glen Lyon.

Major F1 and F2 folds are complicated by co-axial northeasttrending $\mathrm{F} 3$ and F4 folding, as well as by locally important northor NW-trending folds. In the Loch Leven area, nappe-like F1 folds verge to the north-west, whereas to the south-east the major recumbent F1/F2 Tay Nappe verges to the south-east. The trace of the upright Loch Awe Syncline lies between the opposing nappes, but
\end{abstract}


in this region a large mass of late-Caledonian granitic rocks obscures their mutual relationship. Three tectonic 'slides' are identified that are certainly zones of high strain but which in part could be obscuring stratigraphical variations.

The regional metamorphism ranges from greenschist facies on the western seaboard of Argyll to amphibolite facies in most of the remainder of the region. The study of garnets, together with kyanite and staurolite in the schiehallion area, has enabled a detailed history of the metamorphism and structure to be unravelled.

Stratabound mineralization occurs in the Easdale Subgroup, where there is also evidence of changes of sedimentary environment associated with volcanicity and lithospheric stretching. The region is dissected by a series of NE-trending, dominantly leftlateral, faults, subparallel to the Great Glen Fault, whose movement history is illustrated here by that of the Tyndrum Fault. 


\section{INTRODUCTION}

\section{J.E. Treagus}

The Central Grampian Highlands, as defined in this special issue, are bounded to the north-west by the Great Glen Fault between Lismore and Fort William, and to the south-east by the main outcrop of the Loch Tay Limestone Formation between the Tyndrum Fault and Pitlochry (Figure 1). The south-western and north-eastern boundaries are essentially geographical, rather than geological, but they have been chosen to reflect to a certain extent areas studied by a distinct group of workers. The sites in this region have been selected to illustrate both the stratigraphy and the structure of the Dalradian rocks and, to a lesser extent, aspects of their mineralization and metamorphism.

\subsection{Lithostratigraphy and Sedimentary Environments}

Most of the formations of the Appin and Argyll groups are represented, many in their type areas, but only the uppermost of the poorly-correlated Grampian Group formations are represented. Although many of the formations of the Appin and Argyll groups show remarkable similarities in facies across the overall outcrop of the Dalradian, there are significant variations in the lowermost formations of both groups within the Central Grampian Highlands (Figure 2).

The uppermost formations of the Grampian Group are well represented in the GCR site selection, as is the transition up into the Lochaber Subgroup of the Appin Group. Near the north-western section of the boundary with the Northern Grampian Highlands, the contact between the Grampian Group and the Lochaber Subgroup, previously interpreted as the tectonic Fort William slide, has been re-interpreted by Glover (1993) as a local unconformity. Although that area is not represented in the GCR site selection, in the River Leven GCR site, to the east of Loch Leven, this contact can be shown to be a sedimentary transition, contrary to other suggestions (e.g. Lambert, 1975); the passage from the Eilde Flags into the Eilde Quartzite is continuous, both sedimentologically and structurally (Treagus, 1974). The thick sequence of psammites and semipelites of the Lochaber Subgroup in the type area is described in detail in the reports of several GCR sites around the east and north sides of Loch Leven (River Leven, Nathrach, Rubha Cladaidh, Tom Meadhoin and Doire Ban, Stob Ban), which provide abundant evidence from sedimentary structures, especially cross-bedding, for the shallow-water environment. The lens-like bodies of coarse feldspathic metasandstones of the Eilde and Glen coe quartzites, seen in the River Leven and Rudbha Cladaich GCR sites respectively, are entirely local to the Loch Leven area. On the other hand, the clean metasandstones of Binnein-type quartzite, seen in the River Leven, Nathrach, Tom Meadhoin and Doire Ban and Rudbha Cladaich GCR sites, are widespread; they extend both along strike into the South-west Grampian Highlands as the Maol an Fhithich Quartzite of 
Islay and across strike as the thin quartzites seen immediately above the Grampian Group psammites in the River Orchy, Allt Druidhe and Strath Fionan GCR sites. Along strike to the north-east, these quartzites are regarded as members of the more dominanty semipelitic Loch Treig Schist and Quartzite Formation of the Glen Spean area (Key et al., 1997) (see Leslie et al., 2013).

The classic localities of the succeeding Ballachulish Subgroup are described in the St. John's Church, Onich and Ardsheal Peninsula GCR site reports and those of the Blair Atholl Subgroup in the Ardsheal Peninsula and Lismore Island GCR site reports. The type lithologies and sedimentary structures of the shallow-water Appin Group are well illustrated at these GCR sites. Most of these formations can be correlated lithologically with those of the Isle of Islay in the South-western Grampian Highlands (Tanner et al., 2013a), and can be matched virtually formation by formation, with those seen at the Strath Fionan GCR site, in the east of the Central Grampian Highlands, discussed below.

There has been controversy concerning the identity of certain formations within the Appin Group in the Loch Leven area, which has considerable implications for the structural interpretation (e.g. Treagus, 1974; Roberts, 1976; Hickman, 1978). Therefore particular attention has been paid in that area to the nature and 'way-up' evidence at the transitional junctions, in order to test the stratigraphical succession established by Bailey (1960). At the Tom Meadhoin and Doire Ban GCR site, in particular, the description here supports the contention of Roberts (1976) that the quartzite in the core of the Kinlochleven Anticline is the Binnein Quartzite and not the Glen Coe Quartzite as maintained by Bailey (1960) and Hickman (1975). This has considerable implications for the local stratigraphical and structural interpretation.

To the south-west of Loch Leven, in the Benderloch-Loch Creran area, there has also been dispute concerning Bailey's original (1922) stratigraphical attributions (Voll, 1960; Litherland, 1980, 1982). Here the Benderloch Slide, the correlative of the Ballachulish Slide seen within several GCR sites in the Loch Leven area (see below), is seen in the Camas Nathais GCR site (Tanner et al., 2013a); it excises most of the Blair Atholl Subgroup and is now considered to be have had its origins in synsedimentary processes. To the south-east of the slide are formations of the Islay and lower Easdale subgroups of the Argyll Group. According to Litherland (1980), the latter rocks, some of which were attributed to the Appin Group by Bailey (1922) and Voll (1960), as well as those of the Appin Group to their east, show dramatic changes in thickness and lithology in the Loch Creran area. Only limited representatives of these strata occur at the Camas Nathais and Port Selma GCR sites, but the latter includes a spectacular limestone metabreccia, containing microfossils (oncolites, catagraphs and possible bryozoans). This facies, part of a submarine slide deposit, is equivalent to the Scarba Conglomerate in the Easdale Subgroup seen on the Isle of Jura (see Tanner et al., 2013a), but is not seen elsewhere in the Central Grampian Highlands .

To the south-east of the Loch Leven area, the Grampian Group rocks are poorly known and much of the ground is occupied by igneous 
intrusions. In the Dalmally area, the Grampian Group appears to be transitional up into the Appin Group, which is represented only by very abbreviated sequences of part of the Lochaber and Ballachulish subgroups, some of which are seen in the River Orchy GCR site. Here, the Boundary Slide, like the Benderloch slide, brings the abbreviated Ballachulish Subgroup into contact with the pebbly, graphitic facies of the overlying Argyll Group; the Blair Atholl and Islay subgroups are entirely absent. These same relationships extend farther east to the west side of the Schiehallion area (where they are seen in the Allt Druidhe GCR site) and continue north-eastwards, but with the gradual appearance and thickening of the missing formations between the Ballachulish subgroup and the Carn Mairg Quartzite of the Easdale Subgroup (Figure 4a). Thus in the east of the Schiehallion area a complete sequence of the Appin Group is restored, although still abbreviated compared with the type area (Figure 2). The total thickness of the group here is about $1 \mathrm{~km}$ compared with $5 \mathrm{~km}$ at Loch Leven (Treagus, 2000); some of the reduction might be attributed to the higher overall strain in the schiehallion area, although delicate cross-bedding is still preserved in places.

The Schiehallion area provides transitions from the Appin Group, both down into the Grampian Group (at the Strath Fionan GCR site) and upwards (via the Tempar Burn GCR site) into a complete Argyll Group succession. To the north of the Schiehallion area the quartzites and psammites of the Glen Spean Subgroup, at the top of the Grampian Group, are well represented in the A9 and River Garry and Creag nan Caisean-Meall Reamhar GCR sites but correlation with other sequences of the Grampian Group cannot yet be made. The A9 and River Garry GCR site provides an unrivalled wealth of sedimentary structures. The Tempar Burn GCR site contains the classic section for the famous glacigenic Port Askaig Tillite (locally known as the Schiehallion Boulder Bed), here much reduced in thickness compared with the type locality at Port Askaig on the Isle of Islay and the Garvellach Isles GCR site (Tanner et al., 2013a). Immediately to the east of the Strath Fionan GCR site and in the Loch Tummel area, towards the boundary with the North-east Grampian Highlands, the Boundary Slide re-asserts itself. It is not clear to what extent the hiatus attributed to the Boundary slide is due to sedimentological and/or tectonic factors, although the attenuation or absence of sedimentary structures in formations in which they are normally clear and abundant, adjacent to the slide, indicates the importance of high strains.

The remainder of the GCR sites in the central region provide sections through most of the formations of the Argyll Group, many in type localities. From the Ben OSS GCR site near Tyndrum, through the Ben Lawers, Slatich and Strath Fionan GCR sites, eastwards to the Creag an Chanaich to Frenich Burn GCR site near Aberfeldy, all the Argyll Group formations are represented. Although many of the formations can be readily correlated along strike with those in the South-west and North-east Grampian Highlands, significant variations in the stratigraphy occur in the Easdale Subgroup. Facies and thickness variations are particularly noticeable in the turbiditic pebbly sandstones and graphitic mudstones within the Killiecrankie Schist and Carn Mairg Quartzite 
formations. The rare exposures of the Farragon Volcanic Formation, as seen in the Slatich GCR site, provide the earliest evidence of substantial volcanic activity in this sector of the Grampian highland Terrane which, together with the turbidites, heralds a change to a more unstable sedimentary environment.

Two GCR sites have been chosen to illustrate the stratabound mineralization in the Easdale Subgroup, and also provide evidence of changes of sedimentary environment associated with volcanicity and lithospheric stretching. The GCR site at Creag an Chanaich to Frenich Burn contains most of the outcrop of the celebrated 'Aberfeldy' baryte/sulphide mineralization at the upper margin of the Ben Eagach Schist Formation. The GCR site at Auchtertyre, in the Tyndrum district, contains the rare sulphide mineralization that occurs locally at the upper margin of the Ben Lawers Schist Formation.

The Tayvallich Subgroup is represented in the Central Grampian Highlands by the Ben Lawers GCR site. There, it consists dominantly of crystalline metalimestone with only thin amphibolites representing the more substantial volcanic component seen in the type area around Loch Awe in the South-west Grampian Highlands.

\subsection{Structure}

The GCR sites of the Central Grampian Highlands exemplify the classic interpretation of the overall structure of the Grampian Terrane, as described by Stephenson et al. (2013a). The refolded, recumbent NW-facing major folds of the Appin-Loch Leven area are particularly well represented in the Schiehallion-Ben Lawers area. Relationships in the area between these NW-facing folds and the SEfacing Tay Nappe are unclear, not least because of large intrusions of late-Caledonian granitic rocks in the Loch Etive-Moor of Rannoch area. In the South-west Grampian Highlands (Tanner et al., 2013a), the upright Loch Awe Syncline fulfils this central role between the SE-facing Tay Nappe and the NW-facing Islay Anticline; Roberts and Treagus (1977c) have attempted to project this fold into the Central Grampian Highlands. Several GCR sites specifically were chosen to examine three major slides of the region, the Benderloch, Ballachulish and Boundary slides. These slides are of particular interest for the debate as to whether they are, wholly or in part, of sedimentological or tectonic origin.

The structural significance of each of the GCR sites is described below, as far as possible in the context of the two classic areas of Appin-Loch Leven and Schiehallion-Ben Lawers.

In the Appin-Loch Leven area, eight GCR sites illustrate the major folds of the two dominant deformation phases (Figures $3 \mathrm{a}, \mathrm{b}$ ); the descriptions in the text progress essentially from east to west, into areas of decreasing complexity. The descriptions and interpretations in the site reports follow the work of J.L. Roberts and J.E. Treagus, as summarized by Roberts and Treagus (1977a, 1977b, 1977c). This work largely supported the original interpretation of Bailey (1960), but was based primarily on observations of minor structures that were largely ignored by Bailey. These views were challenged in part by Hickman (1978), but Roberts and Treagus (1980) defended their position. 
The three major first-phase folds are the Appin Syncline, the Kinlochleven Anticline and the Ballachulish Syncline (Figure 3b); their D1 age is justified from the evidence of minor structures in the individual GCR site reports. However, the Appin Syncline, as seen at the Ardsheal Peninsula and Onich GCR sites, was interpreted as a D2 structure by Hickman (1978) as was the antiform at the Tom Meadhoin and Doire Ban GCR site and the synform between the Rubha Cladaich and Nathrach GCR sites (the upward- and downward-facing nose of the Kinlochleven Anticline respectively, according to the Roberts and Treagus model preferred here). Hickman also disputed the existence of the Ballachulish Syncline at the Stob Ban GCR site, on stratigraphical grounds. The two major second-phase folds are the Stob Ban Synform and the Kinlochleven Antiform (not to be confused with the F1 Kinlochleven Anticline) (Figure 3b); evidence for their existence and relative age, which has not been disputed, is examined in a number of GCR site reports.

The F1 Appin Syncline, which faces steeply up to the north-west, epitomizes the structural style of the westernmost part of the Central Grampian Highlands. The north-west limb is well represented in the Ardsheal Peninsula GCR site and the core and south-east limb in the Onich GCR sites. Relationships of the F1 minor folds and cleavage to the major fold are exceptionally well seen, as is the growth of chlorite (at Ardsheal) and of biotite (at Onich) in the stretching direction on the S1 cleavage planes. These observations support those of Bailey (1960) and Treagus and Treagus (1971) but contradict both those of Hickman (1978) and those of Bowes and Wright (1967) who suggested that the fold is a product of a third generation of deformation, associated with retrograde metamorphism. These GCR sites also provide evidence of the beginning of the D2 deformation, which increases in intensity eastwards towards the major F2 Stob Ban Synform. The Lismore Island GCR site, at a higher level in the Appin Syncline, although less well known with respect to the D1 history, illustrates the style of D2 particularly well, with large-scale folds that verge in sympathy with the Stob Ban Synform (Hickman, 1978).

The Tom Meadhoin and Doire Ban GCR site gives an unrivalled view of the upward-facing core of the Fl Kinlochleven Anticline, with associated minor structures. In its northern part, it illustrates relatively large-scale F2 folds on the north-west limb of the most significant major fold of that age, the stob Ban Synform, which is fully exposed to the north-east at the stob Ban GCR site. The Rubha Cladaich and Nathrach GCR sites illustrate the downward facing of the D1 structures on the north-west and south-east limbs respectively of the Fl major fold, the Kinlochleven Anticline. Lying on the south-east limb of the Stob Ban Synform, these two sites display D2 minor structures sympathetic to the major fold and syn-D2 growth of garnet is well seen. The south-east limb of the complementary F2 Kinlochleven Antiform, to the east of the Stob Ban Synform, is represented by the River Leven GCR site, although the D1 facing here is not well documented.

The St John's Church GCR site has been chosen to illustrate the Ballachulish Slide, a major dislocation, also seen in the Tom Meadhoin and Doire Ban GCR site, which removes part of the succession on the common limb between the Kinlochleven Anticline 
and the next highest major F1 fold, the Ballachulish Syncline. This structure was originally a low-angle syn-D1 normal fault according to Bailey (1960), but it has been suggested by soper and Anderton (1984) that it had a syn-sedimentation origin. According to Roberts and Treagus (1977a, 1977c), the Ballachulish Syncline is the correlative of the Loch Awe Syncline of the South-west Grampian Highlands. The documented stratigraphical evidence for the existence of the Ballachulish Syncline (Roberts, 1976) is given in the Stob Ban GCR site report; however, this evidence and evidence for the age of the Ballachulish slide at that site clearly need reexamination. The Rubha Cladaich and Nathrach GCR sites also provide evidence for a set of structures that, according to Treagus (1974), are associated with the major post-D2 swing in strike of the earlier structures across Loch Leven (Figure 3a).

In the Schiehallion-Loch Tay area (Figure $4 \mathrm{a}, \mathrm{b})$, the site descriptions and interpretations follow the work of Nell (1984) and Treagus (1987, 2000), but differ substantially from the earlier views of Bailey and McCallien (1937) and of Rast (1958). Three GCR sites (Creag nan Caisean-Meall Reamhar, $A 9$ and River Garry and Strath Fionan,) illustrate aspects of the structure of the Schiehallion district, where major F1 folds on the lower limb of the SE-facing Tay Nappe are folded by major F2 folds. The Allt Druidhe GCR site has been chosen to illustrate the high strains associated with the Boundary slide in this area and that at Meall Dail-chealach demonstrates the style of major late kink folds. To the south of Schiehallion, minor structures at the Slatich GCR site in Glen Lyon can be used to demonstrate the D2 age of a major fold, the Ruskich Antiform, which can be traced laterally to the southwest into the Ben Lui Fold; these F2 folds are major components of the architecture of the Grampian Terrane, at the north-western margin of the Tay Nappe. The Slatich and Ben Lawers GCR sites also exemplify D3 minor structures superimposed on those of the D1 and D2 phases. These sites also provide a structural link between the Schiehallion district and the Flat Belt, part of the inverted limb of the Tay Nappe, which dominates the structure of the southeastern Dalradian. The Ben Lawers GCR site in particular contains the hinge-zone of one of the major post-D2 folds that affect the Flat Belt, the F4 Ben Lawers Synform.

In the Tyndrum area the River Orchy GCR site, in a comparable position and along strike to the south-west of the A9 and River Garry GCR site, contains the hinge-zone of a major SE-facing early fold, the presumed D1 age of which has recently been shown to be D2 (Tanner and Thomas, 2010). The nearby Ben OSS GCR site, uniquely in this special issue, has been chosen to illustrate the history of movement and mineralization on a major fault, the NE-trending Tyndrum Fault, which is one of several that cause major displacements within the Grampian Terrane.

\subsection{Metamorphism}

The selected GCR sites encompass rocks in both the greenschist and amphibolite facies. The greenschist-facies rocks are characteristic of the western seaboard of Argyll and of the Highland Border region; the remainder of the region is occupied by 
amphibolite-facies rocks. The Ardsheal Peninsula and Onich GCR sites exemplify, particularly well, low-grade slaty and phyllitic rocks. Chlorite-muscovite stacks at the former site and biotite crystals, up to $10 \mathrm{~mm}$ long at the latter site, are visibly elongated in the stretching direction on the S1 cleavage surfaces. To the east of these two GCR sites, the rocks pass into the lower amphibolite facies, coincident with the onset of the D2 deformation. Garnet and K-feldspar porphyroblasts are especially prominent in the Binnein Schist at the Rubha Cladaich GCR site; there it can be seen that these porphroblasts are wrapped by the dominant S2 schistosity and include the S1 fabric.

Garnet is prominently displayed in schistose rocks across the central part of the area, and is well seen at the River Orchy, Strath Fionan and Tempar Burn GCR sites, here too with clear wrapping by the dominant S2 fabric; curved helecitic inclusion trails of $\mathrm{Sl}$ can also be seen in the field within the porphyroblasts. Amphibole (syn- to post-D2) is well developed in the Farragon Volcanic Formation at the Slatich and Ben Lawers GCR sites, and in the concordant amphibolites at the Strath Fionan GCR site. The Ben Lawers Schist Formation at the Creag an Chanaich to Frenich Burn GCR site displays coarse crystals of amphibole but within the Ben Lawers Synform (in the Ben Lawers GCR site) the formation is in the greenschist facies. Both staurolite (syn-D2) and kyanite (cross-cutting S2) are seen at the Strath Fionan GCR site.

\section{RIVER LEVEN SECTION} (NN 191 619-NN 205 189)

\section{J.E. Treagus}

\subsection{Introduction}

The River Leven, east of Kinlochleven, provides a virtually continuous section, from the uppermost formation of the Grampian Group (the Eilde Flag Formation) through the three lowest members of the Loch Treig Schist and Quartzite Formation at the base of the Appin Group (the Eilde Quartzite, the Eilde Schists, and the Binnein Quartzite) (Figure 5). Its importance lies in the fact that a sedimentary transition between the Grampian and Appin groups can be clearly demonstrated. In addition, structural information from these rocks, in conjunction with that from other GCR sites around Loch Leven to the west, enables the large-scale tectonic picture of the western Grampian fold-belt to be understood. The exposures in the present-day bed and banks of the river are complemented in the east by those in an old course of the river and in the west by exposures adjacent to a pipeline.

The stratigraphical succession and the broad structural relationships of the Kinlochleven area have been described by Bailey (1960), with detailed structural data relating to the two regional phases of deformation being provided by Treagus (1974). A description of the GCR site was included in a guide to the Loch Leven area by Roberts and Treagus (1977b). A different 
interpretation of the structure was proposed by Hickman (1978), but this was refuted by Roberts and Treagus (1980).

\subsection{Description}

The GCR site extends from the youngest rocks at 1910 6186, just west of the old bridge across the River Leven at Kinlochleven, east to the oldest at 20476088 , some $1.7 \mathrm{~km}$ upstream (Figure 5). At the former location, and for some $400 \mathrm{~m}$ upstream, are excellent exposures of the well-bedded, pure white, Binnein Quartzite with plentiful cross-bedding that youngs consistently to the west in vertical rocks (Figure 6). Characteristic rusty spots, a few millimetres in length are seen elongated parallel to a steep westdipping cleavage in interbedded pelites. The transitional junction with the Eilde Schists is exposed in the river at about 1950 6173; younging in quartzite ribs immediately east of the junction is to the west.

The Eilde Schists are dark-grey pelites and semipelites with ribs of quartzite and feldspathic psammite, particularly near the top and bottom transitional beds, where carbonaceous and calcareous beds are also more common. Much of the accessible outcrop is in the flat limbs of folds, which are knee-shaped and tens of metres in wavelength; these folds verge north-west with an axial-planar, steep NW-dipping, intensely-developed, crenulation cleavage. The junction of the Eilde Schists with the Eilde Quartzite is exposed at about 2006 6150, on the vertical limb (some $50 \mathrm{~m}$ wide and striking $037^{\circ}$ ) of a major fold; to the east a flat limb, some $100 \mathrm{~m}$ wide is exposed at waterfalls, where inverted cross-bedding and slump-folds are excellently displayed in the feldspathic quartzites. The dip then gradually increases to the east across a major fold hinge, to return to vertical at about 2025 6606; some good exposures are seen in the old river course which runs northwest from here. Associated with this major fold are small-scale folds in thin quartzite beds and a steep axial-planar crenulation cleavage in the pelites.

The junction with the Eilde Flags at the top of the Grampian Group is easily identified at the point where an overflow channel from the pipeline to the south joins the river at 2026 6598. Thinribbed psammites and semipelites occur to the east of the reddened quartzites of the Eilde Quartzite, with typical Grampian Group thicker-bedded feldspathic psammites coming in immediately east of a porphyritic microdiorite dyke. Westward-younging cross-beds and slump-folds in the steep east-dipping rocks are well-seen throughout, but one $5 \mathrm{~m}$-wide unit, between two waterfalls on the north bank, displays $10 \mathrm{~cm}$ - to 1 m-thick beds of slump folds particularly well, together with $50 \mathrm{~cm}$-thick beds of unusually pebbly psammites. Pebbles in the latter are strongly elongated, up to a length of $4 \mathrm{~cm}$, in the plane of the dominant, steep westdipping, crenulation cleavage. Cleavage/bedding intersections are sub-horizontal (e.g. $5^{\circ}$ to $\left.062^{\circ}\right)$. 


\subsection{Interpretation}

The section in the River Leven is so unbroken and the way-up indicators are so unambiguous, that there can be no doubt that it provides a continuous stratigraphical section from the Eilde Flags (oldest), at the top of the Grampian Group, through the Eilde Quartzite and the Eilde Schists into the Binnein Quartzite, the lowest members of the Loch Treig Schist and Quartzite Formation at the base of the Lochaber Subgroup in the Appin Group. Most importantly, the attitude and style of the minor structures is consistent throughout the section and there is no evidence for a tectonic or metamorphic break at the junction between the Grampian and Appin group rocks. This observation became important with the assertion by Piasecki and van Breeman (1983) that rocks near Aviemore, which they assigned to the lower part of the Grampian Group, share a structural and tectonic event, then dated at $750 \mathrm{Ma}$, with underlying migmatitic rocks. Since there is no evidence in the Appin Group of events of this age, it appeared at that time that there must be a tectonic and/or metamorphic break within, or at the top of, the Grampian Group. However, since all of the rocks with evidence of a 750 Ma or older event (the date has subsequently been revised to c. $800 \mathrm{Ma}$ ) are now regarded as part of the preGrampian Group Badenoch Group (see Leslie et al., 2013), such an interpretation is no longer necessary.

The Grampian-Appin group junction exposed in the River Leven had been proposed as a possible site of a major tectonic boundary on the basis of the change in sedimentary environment (Lambert, 1975). However, the change in the nature of the metasedimentary lithologies at this junction does not mark a dramatic alteration in the original sedimentary environment. The major change is from the more-feldspathic (K-feldspar rich in thin section) Eilde Flags and their unusually coarse pebble beds into the cleaner Eilde Quartzite (plagioclase rich in thin section); however, psammites with mixtures of both feldspars occur in both the Eilde Quartzite and Eilde Schists, as well as in the Glen coe Quartzite to the west of the GCR site, and the 'background' semipelite and pelite in all units remains of a consistent nature. The scale and nature of the cross-bedding and slump-folds also remains consistent across the junction.

Throughout the section, the minor- and intermediate-scale folds, with their associated cleavage, consistently verge north-west in a series of step-like folds. The cleavage in the pelites is very intensely developed and might be mistaken for a first cleavage, but in thin section it is clearly a crenulation of an earlier penetrative cleavage (Treagus, 1974). In fact in some locations it is possible to see an angle between bedding and this earlier penetrative cleavage, but the plunge of their apparent intersection and their vergence relationship is so variable as to render these observations of no use in the determination of facing of the first structures. The folds and dominant cleavage belong to the regional D2 phase of Treagus (1974); the intermediate-scale folds are on the eastern limb of the major F2 Kinlochleven Anitiform (which can be seen clearly from the western part of the GCR site in the hills to 
the north of Kinlochleven). Minor F2 folds and cleavage on the western limb of this fold are seen in the Nathrach GCR site. At Nathrach, D1 structures face downwards and, according to the regional structural interpretation of Treagus (1974), the Kinlochleven Antiform would be responsible for a change in the facing of D1 structures to steeply upward-facing on its eastern limb; this facing has not been confirmed in the rocks exposed in the River Leven GCR site, but should be a subject of future research. Bailey (1960), by contrast, considered that the rocks of this GCR site lie in the hinge area of a major recumbent F1 syncline, facing towards the west, a view that was shared by Hickman (1978). In the latter view, minor Fl folds and their axial planar cleavage would be recumbent, but the minor structure evidence presented here does not conform with that interpretation.

\subsection{Conclusions}

The River Leven Section GCR site is of national importance in demonstrating the continuity of sedimentation and the similarity of structural features across the boundary between the Grampian and Appin groups of the Dalradian succession. It is therefore not a candidate for the location of a major break in the history of geological events in the Scottish Highlands, as had once been suggested. The site provides a unique continuous section across the topmost formation of the Grampian Group into the loweest formation of the Appin Group and is rich in structures that provide evidence both for the sedimentary environment of these rocks and for their deformation history. The small-scale deformational structures (folds and cleavages) are important in the reconstruction of the largest-scale folds, many kilometres in length, that make up this western part of the Grampian Mountain Belt; the site will be important for further research in this respect.

\section{NATHRACH (NN 164 624)}

\section{J.E. Treagus}

\subsection{Introduction}

The Nathrach GCR site, which is on a well-exposed hillside above the main road on the north side of Loch Leven west of Kinlochleven, has both stratigraphical and structural importance. Firstly, it contains fine exposures of the Binnein Schist and Binnein Quartzite members of the Loch Treig Schist and Quartzite Formation (Lochaber Subgroup) and of their transitional junction (Figure 7). The exposures of quartzite are rich in sedimentary structures. Secondly, the interbedded thin quartzites and pelites of the transitional beds contain minor structures, unrivalled for their clarity (Figure 8), which give important information on both the geometry and position of major folds of two deformation phases. The locality is therefore critical, together with other GCR sites 
(River Leven, Rubha Cladaich, St John's Church, Tom Meadhoin and Doire Ban and Stob Ban) to the interpretation of the large-scale recumbent refolded folds which characterize the Loch LevenBallachulish area.

The stratigraphy and the structure of the GCR site have been described by Bailey (1960) and Treagus (1974). A description of the site is also included in a geological field guide to the Loch Leven area by Roberts and Treagus (1977b).

\subsection{Description}

There are three areas of interest in this GCR site. The principal interest is in the structure of the Binnein Schists, as displayed in a series of prominent NW-facing exposures about $50 \mathrm{~m}$ long at around 16566235 (Figure 7, locality A). The member here comprises finely bedded pelite and semipelite with some interbedded centimetre- to 0.5 metre-thick white quartzite beds. Cross-bedding in these pure quartzites, which are of a similar facies to the Binnein Quartzite, youngs to the north-west in the near-vertical NE-striking beds. The exposures provide numerous examples of tight folds (F2 in the interpretation below) with centimetre- to metrescale amplitude and wavelength (Figure 8). At the south-western end of the crags, the plunge of these folds is at steep angles (70$80^{\circ}$ ) to the south-west, but towards the north-eastern end they plunge steeply to the north-east. The penetrative fabric of the pelite, which is subparallel to the bedding, has been affected by a tight crenulation cleavage (S2), which is near vertical, NEstriking and axial planar to the folds; the penetrative fabric in the semipelite is tightly folded together with the bedding. The vergence geometry of the folds and of the bedding in relation to the crenulation cleavage is of an 'S' type (assuming an average vertical plunge). In certain exposures it is possible to see that earlier folds (F1) are deformed by this main set; neither the vergence nor the plunge of these early folds is easily measured, but the nature of the interference patterns shows that they are not precisely co-axial with the later set. The earlier folds have the penetrative cleavage (S1) in the semipelite parallel to their axial surfaces. A weaker, NNE-trending, crenulation cleavage associated with more-open folds is developed locally; this is the third set of structures more fully described at locality $\mathrm{C}$, below.

The second area of interest is the structure of the Binnein Quartzite, best seen in prominent crags centred about 16406237 , some 10-50 m west of a sharp change of slope which marks the Binnein Quartzite-Binnein Schist junction (Figure 7, locality B). Here, the member consists of white quartzite, well bedded (10-90 cm-thick beds) with rare semipelite and pelite units. Crossbedding, not easily seen near the junction with the Binnein Schists, is seen to young consistently to the south-east in the near-vertical NE-striking beds. Of particular interest are thin $(10 \mathrm{~cm})$ beds of quartzite, interbedded with the pelite and semipelite, which commonly display well-developed tight folds. These asymmetric folds, with a short limb length of some $10-20 \mathrm{~cm}$, plunge at $30-50^{\circ}$ to $070^{\circ}$, have a ' $Z$ ' geometry and have a penetrative schistosity in the semipelite parallel to their axial-surfaces, as 
noted in the F1 folds at locality A (Figure 9). In the adjacent pelites, a crenulation cleavage (of the type noted above related to the later F2 folds) is developed, which transects the F1 folds; folds related to this cleavage are not developed here, although they are seen, with the characteristic ' $S$ ' geometry, in more schistose lithologies nearer to the junction with the Binnein Schists. Similar relationships can be observed elsewhere near this junction (Eigure 7).

The third area is a series of crags at the top of a small hill near the road at 16306205 (Figure 7, locality C), which exposes Binnein Schists of the type described at locality $A$, and in a similar structural position. Metre-thick quartzites, north striking and near vertical, display excellent cross-sets younging to the west. The quartzites are affected by open folds, and the interbedded pelites display the development of an axial-planar, wide-spaced $(1 \mathrm{~cm})$, crenulation affecting the two earlier cleavages described above. The axial surfaces of these crenulations strike east-north-east and are near vertical; the plunge of this third set of folds is approximately vertical.

\subsection{Interpretation}

The Nathrach GCR site is located across the transitional junction between the Binnein Quartzite and the Binnein Schists and, although a totally continuous section is not exposed, the abundant easterlyyounging cross-bedding in the quartzites at locality $B$ leaves no doubt that the schists are the younger member. In a regional context, this junction is on the western, sub-vertical, limb of a tight, upright, antiform which closes to the north-east on sgor an Fharain (180 640) (Figure 3a). The same transitional junction on the eastern limb of the fold can be examined east of the Nathrach Burn around 170627 where cross-bedding youngs to the west (Figure 7). Bailey (1960), from stratigraphical considerations, proposed that this fold (named the Mamore Syncline by Treagus, 1974) is a downward-facing D1 structure, a major subsidary fold on the eastern limb of the regional Kinlochleven Anticline. This proposal is consistent with the minor structures observed in the western area of the GCR site at locality $B$, which show that the rocks face downwards on the first penetrative cleavage, related to minor folds that must lie on the western limb of a major syncline (see also Treagus, 1974). These observations are complemented by those at the Rubha Cladaich GCR site, which lie on the western limb of the downward-facing Fl Kinlochleven Anticline.

To the east of the junction of the Binnein Quartzite and Binnein Schists, at locality $A$, interbedded quartzites within the Binnein Schists young towards the west. Since the crenulation cleavage and related minor folds (D2 of the regional structure) have the same vergence here as in locality $B$, the fold between the two localities must either be a subsidiary Fl fold related to the Mamore Syncline or the major fold itself. The importance of these observations is to show that the major reversals of younging in the area are the product of the downward-facing D1 folding and not of the D2 phase. Similarly, the consistent vergence of the D2 structures here and in the Rubha Cladaich GCR site, on the opposing limb of the 
Kinlochleven Anticline, can be used to demonstrate the D1 age of that fold.

Locality $C$ exhibits examples of a third generation of minor folds (F3), and a related E-W-trending crenulation cleavage (S3). Both are geometrically associated with the major swing in strike, to a south-east direction, of all earlier structures across Loch Leven (Figure 3,3a). Treagus (1974) suggested that this change in strike (the Loch Leven Fold) on the south side of the loch might be the result of the intrusions of the Glen Coe Caldera-volcano Complex of late-Silurian age. The re-interpretation of this volcanism in a NW-orientated graben, resulting from regional NE-directed tension or from a transtensional scenario (Moore and Kokelaar, 1997), might account for such a deflection in the adjacent Dalradian rocks.

\subsection{Conclusions}

The importance of the Nathrach GCR site lies in its wealth of sedimentary structures across the junction between two members of the Loch Treig Schist and Quartzite Formation (Lochaber Subgroup) and in its abundant minor tectonic structures (folds and cleavages) of unrivalled clarity. Taken together, these structures demonstrate that the earliest major folds, of many kilometres amplitude and originally probably flat-lying, have been bent by later forces to assume remarkable, totally downward-facing (i.e. upside-down) attitudes. Even later forces have twisted the earlier folds yet again through $90^{\circ}$ to change the whole grain of the country rock for several tens of kilometres, which may be related to the tensional opening of the crust associated with development of the Glen Coe Caldera-volcano to the south.

\section{RUBHA CLADAICH (NN 120 610-NN 133 613)}

\section{J.E. Treagus}

\subsection{Introduction}

The Rubha Cladaich GCR site, adjacent to the main road on the north shore of Loch Leven, provides important sedimentological and structural information in a section across three members of the Loch Treig Schist and Quartzite Formation in the Ballachulish Subgroup of the Appin Group. The sedimentary make-up of the three members (Glen Coe Quartzite, Binnein Schist and Binnein Quarzite), their transitional facies and their sedimentary structures can be seen clearly on clean glaciated surfaces. In addition, the evidence from minor structures supports the relative ages and geometry of the three principal phases of deformation in the region. Together with complementary information from the Nathrach GCR site, these structures can be used to demonstrate the D1 age of the dominant major fold in the area, the Kinlochleven Anticline. The rocks at this site are exceptionally rich in porphyroblasts both of garnet and of plagioclase, which can be related to the structural history. 
The principal features of the GCR site have been described by Bailey (1960), Treagus (1974), and in a field guide to the Loch Leven area by Roberts and Treagus (1977b) .

\subsection{Description}

This GCR site provides both sedimentological and structural information from the base of the Glen coe Quartzite, down through the Binnein Schists into the top of the Binnein Quartzite in a series of shoreline exposures, complemented by road-cuttings (Figure 10). At the western margin of these exposures (NN 1216 6098 to 1228 6098), the peninsula of Rubha Cladaich exposes glaciated surfaces of the thick-bedded $(0.5-2 \mathrm{~m})$ feldspathic Glen Coe Quartzite. The western edge of the exposure is part of a steep $\mathrm{N}$-dipping 'short' limb of a major steeply-plunging fold, the long limb of which, dipping at $48-72^{\circ}$ to the west-north-west, occupies the remainder of the exposure to the east. Cross-bedding, in 30 cm-thick sets younging to the south, is particularly well seen on the short limb, by the mouth of a small burn. Other sedimentary features that are seen in the quartzites on both limbs include ripple cross-lamination, slump folds and mud-flakes that are associated with thin pelitic beds (centimetres thick). The latter contain thin string-like concentrations of feldspar clasts up to 2 $\mathrm{cm}$ long.

The hinge area of the major fold, which is exposed on the main promontory to the east of the burn, has a vertical penetrative axial plane schistosity that strikes $072^{\circ}$. Calculated plunges of minor folds within the hinge are variable from steep (e.g. $80^{\circ}$ to the south-west), through vertical, to $44^{\circ}$ to $020^{\circ}$; the latter are presumed to be more typical of the regional plunge of the major folds (Treagus, 1976). The NNE-striking long limb of the fold is corrugated by metre-wavelength, open folds with axial-surfaces trending east-north-east that are locally associated with a widely spaced crenulation cleavage.

To the east of the main promontory the next exposures, around 1233 6098, contain the Glen Coe Quartzite-Binnein Schist junction, showing a transition from metre-thick quartzites in semipelite into garnetiferous pelites with only thin $(10 \mathrm{~cm})$ beds of quartzite. The latter quartzites exhibit cross-bedding and channel structures that indicate younging to the west. In the Binnein Schists, porphyroblasts both of plagioclase feldspar and of garnet are common in the pelites. Both are wrapped by a dominant, nearvertical, crenulation cleavage (e.g. $\left.070^{\circ} / 86^{\circ} \mathrm{NW}\right)$ that crosses the bedding (e.g. $020^{\circ} / 70^{\circ} \mathrm{W}$ ) in a clockwise sense; minor folds related to the cleavage show consistent ' $S$ ' vergence and plunge to the south-west $\left(\mathrm{e} . \mathrm{g} .40^{\circ}\right.$ to $\left.335^{\circ}\right)$. Of particular importance, seen in the middle of this exposure, are several 10-20 cm-wavelength isoclinal folds (FI in the interpretation below) that are clearly folded or are cross-cut by the dominant crenulation cleavage (S2) and its associated minor folds (F2) (Figure 11). These earlier folds, which have a penetrative schistosity (S1) parallel to their axial-surfaces, plunge steeply to the north-east and have an ' $S$ ' vergence. Particularly clear patterns produced by the interference of the two sets of folds are seen at the extreme edge of this 
exposure at about NN 1249 6101. Similar relationships can be seen on a steep glaciated surface farther east at NN 12626004 . Locally, open folds (F3) with E-W-trending axial surfaces and a coarse crenulation cleavage, deform the earlier cleavages.

The junction of the Binnein Schists with the Binnein Quartzite is exposed in a road-cutting at NN 1267 6017, where there is a transition over a distance of a metre from the typical Binnein Schist lithology, described above, into thinly-bedded (centimetrethick) pure quartzite. The quartzite, which dips at about $50^{\circ}$ to the west, becomes thicker-bedded eastwards, with $30 \mathrm{~cm}$-thick units and clear cross-sets younging to the west that are best displayed near the end of the roadcut (NN 1284 6027), but also seen on the foreshore at NN 1279 6020. Also seen are folds of a metre wavelength, with a similar geometry to the dominant $F 2$ set in the previous exposures, which plunge moderately to steeply to the south-west with an ' $S$ ' vergence.

\subsection{Interpretation}

The almost continuous exposure across the two boundaries between the three members gives an exceptionally compact section in which the nature of this sedimentary succession, the detail of its sedimentary structures and its way-up can be studied.

Structurally, the importance of the site lies in the clear superimposition of the three regional phases of deformation. The folds and cleavage in the Glen Coe Quartzite are identifed as D1, as no earlier structure can be observed; their plunge and vergence are compatible with their position on the upper limb of the major downward-facing F1 Kinlochleven Anticline, which lies in the outcrops of Eilde Quartzite and Eilde Schist between here and the Nathrach GCR site to the east. In the adjacent Binnein Schists, the S1 schistosity is intensely crenulated by the dominant S2 cleavage, but clear examples of F1 folds are also preserved (Figure 11). The D2 minor folds complement those seen at the same stratigraphical boundary in the Nathrach GCR site. Their plunge and vergence demonstrate that the Kinlochleven Anticline is crosscut by the D2 structures and also support the interpretation of the geometry and position of the major F2 stob Ban Synform to the west (see also the Stob Ban and Tom Meadhoin and Doire Ban GCR site reports). The growth of the garnet and plagioclase porphyroblasts can be seen to be associated with the development of the S2 cleavage that wraps them, both in thin section and in hand specimen (Treagus, 1974).

The third generation of minor structures is seen in the open folds of the Glen Coe Quartzite exposures and as the coarse ENE-striking crenulation cleavage in the Binnein Schists. These structures are related to the regional F3 Loch Leven Antiform, which is responsible for the deflection of the regional north-east strike into the south-east strike on the $\mathrm{S}$ side of Loch Leven (Treagus, 1974; Figure 3a; see also the Nathrach GCR site report).

The interpretation of the D1 and D3 major structures given here agrees with the interpretation of Bailey (1960), which was supported by the minor structural data given by Treagus (1974). The latter author used the minor structures to propose the present 
three-phase history. However, Hickman (1976) refuted that the downward-closing fold between the present site and that at Nathrach is the closure of the F1 Kinlochleven Anticline, attributing it to a secondary phase, although he did not present any specific data to support this interpretation. His main argument, from the NWstriking exposures on the south side of Loch Leven, appeared to be that minor Fl folds plunge to the south-east on the south-west limb and to the north-west on the north-east limb and thus must be folded around the major closure. However, the data presented here and in the Nathrach GCR site report show that F1 minor folds exhibit a considerable variation in plunge from steep to the southwest, through vertical to gentle NE-plunging attitudes. Allowing for the late swing of strike across Loch Leven, this variation in fold geometry is similar to that recorded by Hickman, but here it can be seen within a single Fl major fold limb. Furthermore, there is no evidence from post-D1 minor structures to support the existence of a major secondary synform to the east of the Rubha Cladaich GCR site.

\subsection{Conclusions}

The Rubha Cladaich GCR site provides both essential sedimentological and structural information for the interpretation of the Dalradian of the western side of the Grampian mountain belt. Firstly, it allows the establishment of the stratigraphical succession of the lower part of the Appin Group (the Glen Coe Quartzite, Binnein Schist and Binnein Quartzite members of the Loch Treig Schist and Quartzite Formation) in an unusually compact and continuous shore section. Sedimentary structures, which give information concerning the conditions of sedimentation, as well as the way-up of the succession, are particularly well preserved on clean glaciated surfaces. Similarly, these surfaces provide clear evidence of minor tectonic structures (folds and cleavages) of three generations. Study of these structures, particularly in the context of adjacent GCR sites allows the geometry and relative age of major folds of the three generations to be understood.

This site complements the Nathrach GCR site in demonstrating the dramatic large-scale closure of the Kinlochleven Anticline, the most important of the early regional folds in the area, which is here totally inverted by the second phase of deformation. It also exhibits still later folds, with their associated cleavage, which are essential to the understanding of the regional swing in the trend of the beds and earlier structures through $90^{\circ}$ across the eastern end of Loch Leven. 


\section{TOM MHEADHOIN AND DOIRE BAN \\ (NN 071 610-NN 091631 AND NN 097 634-NN 089 645)}

\section{J.E. Treagus}

\subsection{Introduction}

The GCR site at Tom Meadhoin and Doire Ban occupies a summit ridge between Loch Leven and Gleann Righ to the north (Figure 12). It is important for the placing of major folds into the regional deformational picture, establishing in particular the Tom Meadhoin Antiform as the closure of the major Fl Kinlochleven Anticline, which is here upward facing as a result of refolding by D2 structures. Information from this site has also allowed a revision of the stratigraphical identity of lithological units on the north side of Loch Leven, which in turn has lead to a refinement of the structural interpretation. One of the major dislocations of the area, the Ballachulish Slide, which separates the Kinlochleven Anticline from the structurally overlying Ballachulish Syncline, is also exposed.

The rocks were described in some detail by Bailey (1960), who identified the Tom Meadhoin Antiform as an 'early' structure, but a stratigraphical revision was made by Roberts (1976) who also provided the structural detail reported here.

\subsection{Description}

The stratigraphical succession of this site (Figure 12) is in the Appin Group. It progresses from the Binnein Quartzite (oldest) through the Binnein Schists and the Glen coe Quartzite into the Leven Schists (all Lochaber Subgroup) and then across the Ballachulish Slide into the abbreviated Ballachulish Limestone and Ballachulish Slates of the Ballachulish Subgroup. The Binnein Quartzite is the best-seen unit, being prominently exposed on the crags of Tom Mheadhoin, where it forms the core of a doublyplunging antiform, the Tom Meadhoin Antifform (Bailey, 1960) The rock is a well-bedded, pure-white quartzite in which the dip can be readily measured to demonstrate the north-easterly and southwesterly plunges at its north-eastern and south-western ends respectively. The craggy outcrops between NN 099629 and NN 084 620 exhibit many examples of cross-bedding, unambiguously younging up towards the boundary with the surrounding schists.

The transitional facies from the Binnein Quartzite to the Binnein Schists consists of impure quartzites (commonly cross-bedded) and dark pelite and semipelite (commonly graded), as seen in the Rubha Cladaich GCR site. These lithologies are well seen at the northeastern end of the antiform (NN 095 637), and on both limbs of its south-western closure at NN 620088 and NN 083 620. At these three exposures the angular relations between the steep NW-dipping penetrative cleavage and the shallower dipping bedding clearly shows that the cleavage is axial-planar to the major fold. The cleavage/bedding intersections plunge at about $35^{\circ}$ to the north-east 
at the north-eastern closure of the antiform and at less than $20^{\circ}$ to the south-west at its south-western end.

A thin feldspathic quartzite can be traced from the shore at Loch Leven, north-eastwards along the south-east side of the outcrop of the Binnein Quartzite and Binnein Schists on Tom Mheadhoin (Figure 12). This outcrop of the Glen Coe Quartzite is also well exposed to the south-east of Doire Ban, from about NN 097636 to NN 092 641, where it defines a synform and an antiform. These folds plunge to the north-east, as is seen from the changing dip of bedding and the plunge of the intersection of a crenulation cleavage with the bedding. The crenulation cleavage is axialplanar to the major fold-pair.

The Leven Schists and younger formations to the east and north of the succession described above are not well exposed in the area of this GCR site. However, the Ballachulish Slide, which brings the younger formations (the Ballachulish Limestone, the Ballachulish Slates and the Appin Quartzite) against the Leven Schists can be located within the area. In a gully of a burn draining east from Doire Ban, about NN 096 645, the Leven Schists are in contact with the Ballachulish Slates, with an intervening thin remnant of Ballachulish Limestone in places. The location of the slide can be followed south-west around the antiform/synform pair discussed above. To the north-east of Tom Meadhoin the slide can also be located at the head of a burn at NN 091 625, where the Ballachulish Limestone is missing and the Ballachulish slates are brought against the Leven Schists. The flagginess of the rocks at these exposures of the Ballachulish Slide appears to be parallel to the penetrative cleavage in the adjacent rocks.

\subsection{Interpretation}

Perhaps the most important aspects of this GCR site are the reinterpretation of the quartzite of Tom Meadhoin as the Binnein Quartzite, surrounded by the Binnein Schists, and the identification of the dominant structure as an F1 fold core by Roberts (1976). Bailey (1960) had interpreted both this outcrop of quartzite and the quartzite outcrop to its south-east as the Glen coe Quartzite, occupying two antiformal cores, with a synform in the intervening schists (his Leven Schists). He interpreted the three folds as comprising the upward-facing hinge of the Kinlochleven Anticline, one of the major early recumbent nappes folded into an upright position by the secondary stob Ban Synform (see the stob Ban GCR site report). The relations of the S1 penetrative cleavage to bedding seen at this GCR site confirm that the Tom Meadhoin Antiform is indeed a D1 structure and a true anticline (Roberts, 1976). However, the quartzite in the fold core on Tom Meadhoin is undoubtedly the Binnein Quartzite, from its clean, white, well-bedded character and its characteristic transition to the Binnein Schists. This revision of the stratigraphy removes the need for the two folds to the south-east of Tom Meadhoin. It also confirms the progressive thinning of the Glen Coe Quartzite from $2 \mathrm{~km}$ at its type locality on the south side of Loch Leven, to a few hundred metres north of Mam Gualainn (118 638) (Figure 12), as described by Treagus (1974), to a few tens of 
metres at Doire Ban. Furthermore, to the north-west of this GCR site, the expanse of pelite identified as Leven Schists by Bailey (1960) must represent a direct passage from the Binnein Schists into the Leven Schists, in which the Glen Coe Quartzite is not represented at all.

A second important structural observation is that the two NEplunging folds of the outcrop of the Glen Coe Quartzite on Doire Ban are associated with a crenulation cleavage and are therefore of D2 age in the regional deformation sequence. These folds are subsidary folds to the regional sw-plunging F2 Stob Ban Synform, which crops out to the south-east (see Figure 12 and the Stob Ban GCR site report). This $F 2$ fold is responsible for the folding of the once-recumbent Kinlochleven Anticline to its upward-facing position at Tom Meadhoin and its downward-facing attitude farther east (see the Rubha Cladaich and Nathrach GCR site reports).

As Bailey (1960) pointed out, the Ballachulish Slide appears to be contemporary with the early (D1) deformation in this area, which is confirmed by the observations at this GCR site. However, as Bailey also pointed out, the slide must be an original low-angle normal fault rather than a thrust, as it thins the upper limb of a major anticline, the Kinlochleven Anticline. Soper and Anderton (1984) have suggested that such movements may have taken place during sedimentation. Further research at the site might help to shed more light on this problem.

\subsection{Conclusions}

The Tom Meadhoin and Doire Ban GCR site is of critical importance for the light that it sheds on both stratigraphical and structural arguments in the Dalradian on the west side of the Grampian foldbelt. As well as clarifying the local stratigraphical succession, it enables the dramatic thinning of one formation, the Glen coe Quartzite, to be reconstructed. It also provides an unusually complete view of the hinge area of one of the major folds of the region, the Fl Kinlochleven Anticline. This fold, which was originally flat-lying, extends over a distance of at least $15 \mathrm{~km}$ from Tom Meadhoin eastwards to the River Leven GCR site. A further period of deformation was responsible for the bending of this fold from its original flat-lying attitude into its present upright position and the superimposed structures associated with this D2 event can be well demonstrated. One of the major structural dislocations of the region, the Ballachulish slide, is contemporary with the earlier folding and is also well seen. This GCR site promises to be important for future investigations of the structure of the region. 


\section{STOB BAN \\ (NN 138 658-NN 149 668)}

\section{J.E. Treagus}

\subsection{Introduction}

This GCR site, on the northern side of Stob Ban, one of the highest mountains in the Mamore range, contains the magnificently exposed core of one of the major F2 folds of the Loch Leven area, the stob Ban Synform. This upright, sw-plunging fold is responsible for the change from the downward-facing D1 structures of the Nathrach and Rubha Cladaich GCR sites, to the south-east of this site, to the upward-facing D1 structures of the Tom Meadhoin and Doire Ban and Onich GCR sites to the south-west. At the stob Ban GCR site, the Stob Ban Synform refolds the Ballachulish Syncline, which, along with the underlying Kinlochleven Anticline (seen in the Tom Meadhoin and Doire Ban GCR site) is one of the major, originally flat-lying, F1 nappe structures of the western part of the Grampian fold-belt. The interpretation of the structure is dependant upon Bailey's (1960) interpretation of the stratigraphical succession, which in this area is very abbreviated and is also hornfelsed by a granitic pluton. This interpretation was supported by Roberts (1976) but doubted by Hickman (1978). It is clear from Bailey's description (in Bailey, 1960) that the realization of the existence of this refolding was central to his interpretation of the whole regional structure.

\subsection{Description}

This remote and poorly known GCR site extends from Coire an Lochain, the north-western coire of Stob Ban, across the mountain's north ridge and down the eastern flank into Coire a' Mhusgain. According to Bailey (1960, pp. 47-49), and as recorded by him on the Geological Survey's 1" Sheet 53 (1948), the GCR site contains the isoclinal core of the recumbent Ballachulish syncline, folded by the upright secondary Callert Synform (now known as the Stob Ban Synform). As Figure 13 shows, the right-way-up sequence of thick Leven Schists and $30 \mathrm{~m}$ of Ballachulish Limestone on the lower limb of the syncline (equivalent to the upper limb of the Tom Meadhoin Anticline, as seen in the Tom Meadhoin and Doire Ban GCR site) is followed upwards by $30 \mathrm{~m}$ of the Ballachulish Slates in the core and then the reverse sequence of Ballachulish Limestone-Leven Schists on the upper limb. The two limbs of this once-recumbent F1 fold have subsequently been folded into the tight upright SW-plunging F2 Stob Ban Synform. All of the lithologies have been hornfelsed by the granitic Mullach nan Coirean Pluton.

Further details have been given by J.L. Roberts (1976 and in Roberts and Treagus, 1977b). The first penetrative cleavage (S1) is everywhere parallel to bedding; it has steep south-east dips of $75^{\circ}$ to the south-east on the north-west limb of the stob Ban Synform and near vertical dips on the south-east limb. The closure of the F2 synform is well exposed on the steep eastern slopes of the north 
ridge of Stob Ban (at about NN 146 666). The outcrop of the Leven Schists in the core terminates some $20 \mathrm{~m}$ below the crest of the ridge and the underlying thin Ballachulish Limestone can be traced around the hinge. Below this, the Ballachulish slates in the core of the early Fl syncline and the lower, repeated Ballachulish Limestone and Leven Schist sequence, now right-way-up, can be traced from the hinge both to the north-west and south-east along the ridge (between about NN 147663 and NN 144 668). Minor F2 folds are symmetrical in the hinge-zone and become increasingly northwest vergent to the north-west and increasingly south-east vergent to the south-east, thus demonstrating the D2 age of the major fold.

Another well-exposed section is along the Allt Coire an Lochain which drains north-west from the lochan at NN 141662 just southeast of the synformal fold core. The two outcrops of Ballachulish Limestone (now calcsilicate hornfels) and the intervening Ballachulish Slates are well seen in the gorge (at about NN 140 663), with the upper part of the Leven Schists (now pelitic hornfels) seen at the lip of the corrie (NN 1407 6624). Throughout this section F2 folds, with steeply dipping axial planes, are seen plunging to the south-west and verging to the north-west on the north-west limb of the major F2 synform. The Ballachulish Limestone can be seen on the south-east limb of the synform midway along the north-east shore of the lochan, followed uphill to the east (to about NN 143 661) by the Ballachulish Slate-Ballachulish Limestone-Leven Schist sequence, in which the minor folds verge south-east on the south-east limb of the major F2 synform.

\subsection{Interpretation}

The existence and identity of the Ballachulish Syncline was deduced by Bailey (1960) from the apparent repetition of the Leven Schists and Ballachulish Limestone about the core of Ballachulish Slates. The identities of these formations is made difficult both by their great abbreviation from their thicknesses at their type localities and from their severe hornfelsing by the adjacent granite. Roberts (1976) confirmed the folding of the regional S1 cleavage, parallel to bedding, around the major F2 synform, but he regarded Bailey's interpretation of the stratigraphy and D1 structure to be a working hypothesis, being unable to provide any way-up evidence or D1 minor structure evidence to add to Bailey's observations. Hickman (1978) suggested that the supposed Leven Schist and Ballachulish Limestone sequences are local facies variations within the Ballachulish Slates, although such variations have not been reported elsewhere. In fact, the reality of the stratigraphy of the inverted limb of the major F1 syncline is better demonstrated to the south of the Stob Ban GCR site, between Tom Meadhoin and Callert House (Figure 12), where the Ballachulish Slates are succeeded upwards by a large expanse of Ballachulish Limestone and Appin Quartzite occurs in the fold core.

The sympathetic relations of the S2 crenulation cleavage and F2 minor folds to the major Stob Ban Synform in the area of the GCR site, as reported by Roberts (1976), support Bailey's (1960) identification of that structure as a major component of the secondary deformation in the Loch Leven area. 


\subsection{Conclusions}

The Stob Ban GCR site not only provides sections across one of the major early folds seen in the western Grampian fold-belt (the F1 Ballachulish Syncline), but also contains the hinge of one of the major later folds (the F2 Stob Ban Synform). Later folds such as this are responsible for major variations in attitude of the early folds throughout the Loch Leven area. Despite considerable reductions in thickness of some of the lithological units, relative to their type areas and despite contact metamorphism in the aureole of an adjacent granite, the stratigraphy within the GCR site is clear enough for the repetition of formations on the two limbs of the early fold to be unusually well seen. Moreover, the striking manner of the changing geometry of minor folds across the site can be used to demonstrate perfectly the existence and age of the later, F2 fold. The detailed structural relationships at this GCR site are only poorly known and there is considerable scope for further study.

\section{ST JOHN'S CHURCH, LOCH LEVEN (NN 065 587)}

\section{J.E. Treagus}

\subsection{Introduction}

The St John's Church GCR site, on the south shore of Loch Leven 1.5 $\mathrm{km}$ south-east of the Ballachulish Bridge, provides a rare section across one of the 'slides' (synmetamorphic low-angled faults) that are a major feature of the Dalradian in the western part of the Central Grampian Highlands. An Appin Group succession from the lower part of the Leven Schists up to the base of the Appin Quartzite, is exposed across the core of one of the major recumbent nappes of the area, the Ballachulish Syncline; the Ballachulish Slide occurs on the lower limb of this fold. Here the fold core and the slide are turned into a steeply dipping attitude as a result of later folding.

The exposures were described and the structure was illustrated by Bailey (1960, pp. 58-59, figure 7G); Roberts (1976) and Roberts and Treagus (1977b) have described the general context.

\subsection{Description}

The exposures on the eastern side of the GCR site provide a section from the Ballachulish Slates through transitional beds (the Appin Transition Formation) at the base of the Appin Quartzite, which lies on what was originally the upper limb of the Ballachulish syncline. To the west, two tectonic junctions bring in respectively, a thin slice of Ballachulish Limestone and the basal facies of the Leven Schists (Figure 15). The former lies in the core of the syncline; the latter lies on the original lower limb. The bedding and a penetrative schistosity dominantly dip steeply to the north-west, an attitude acquired during later folding. The 
section is described from south-east to north-west from the shore opposite St John's church.

A group of exposures on the first peninsula on the south-east side of the GCR site (Figure 15, locality A; NN 0669 5869) expose phyllitic graphitic pelites with thin semipelite beds, which are attributed to the upper part of the Ballachulish Slate Formation. Thin beds of gritty quartzite, typical of the transition into the Appin Quartzite Formation, occur at the north-western end of this peninsula. Strongly deformed ripple-drift lamination can be discerned, but way-up is not easily determined. The bedding, together with the penetrative schistosity, strike north-east and dip steeply north-westwards at $80-85^{\circ}$; rarely, the two planar surfaces can be seen at a narrow angle to one another and to be axial planar to tight folds plunging steeply to the south-west. A strongly developed stretching lineation (pyrite blebs and mica) and possibly the intersection lineation pitch down the dip of the schistosity. The schistosity is folded by minor tight folds, which plunge subvertically and dominantly have $a$ ' $Z$ ' geometry and an axial-planar crenulation cleavage.

After a gap of some $50 \mathrm{~m}$, the rocks at the south-eastern end of the second peninsula (Figure 15, locality B; NN 0665 5875) are black phyllitic pelites, with a more variable strike than in the previously described exposures. They become more-dominated by beds of gritty quartzite, up to $70 \mathrm{~cm}$ thick, towards the north-west. Here too, the penetrative schistosity is very close to the bedding and their cross-cutting relationships and the direction of their intersection are difficult to determine. The outcrop of these transitional beds ends at a NE-trending, 4 m-thick microdiorite dyke. Between this dyke and a second 5 m-thick dyke, occurs a 10 m-thick unit of yellow-weathered, grey metacarbonate rock, which is interbanded with millimetre- to centimetre-thick beds of dark semipelite, a lithological association typical of the Ballachulish Limestone Formation. These NE-striking beds are locally strongly folded by steeply plunging minor folds exhibiting both ' $S$ ' and ' $Z$ ' geometries. A critical locality (NN 0663 5882) occurs at the junction of the metalimestone with the western dyke where, over a distance of about one metre, a few centimetres of platy quartzose schist are seen (Figure 16). This schist is interpreted as a slither of the basal facies of the Leven schists, which crop out over the remainder of the peninsula to the west of the dyke. The Leven Schists here consist of quartz-rich psammite interbedded on a centimetre scale with ribs of semipelite; no way-up criteria have been established. One well-exposed minor fold has a plunge of $40^{\circ}$ to the north-east and an 'S' geometry, but otherwise there are no well-developed minor structures.

\subsection{Interpretation}

According to Bailey (1960, pp.55-59) the succession of Ballachulish Slates and the Appin Transition Formation, described above, is corrugated by intermediate-scale folds subsidiary to the Ballachulish Syncline (an Fl fold in modern nomenclature). The core of this syncline lies close to the junction of the transitional beds with the Ballachulish Limestone; the Ballachulish Limestone 
and Leven Schist exposures to the west belong to the lower limb. The minor folds and cleavage/bedding relationships, seen in the section of Ballachulish slates and transitional beds, certainly show varying vergence directions, suggesting such intermediatescale folds of perhaps several tens of metres wavelength. S0/S1 intersections appear to be parallel to the steeply pitching stretching lineation. However, the D1 age of these structures has not been confirmed in thin section in any of the more-recent studies. In fact the existence of the syncline has not been confirmed in current studies, either from minor folds and cleavage/bedding relationships, or from sedimentary way-up structures, (although the synformal structure is clear from the regional stratigraphical context (Figure 15).

According to Bailey (1960) the Ballachulish syncline, which was originally recumbent, has been rotated into its present steep, NWdipping, upward- and SE-facing, attitude by the secondary folding of the region. Some of the folds seen in the section described above are associated with a crenulation cleavage, and their southwesterly plunge and ' $Z$ ' geometry agree with them being $F 2$ folds on the western limb of the major F2 Stob Ban Synform, similar to those described in the Tom Meadhoin and Doire Ban GCR site to the northeast.

Although the junction between the Appin Transition Formation and the Ballachulish Limestone to its west is obscured by a microdiorite dyke, the increase in quartzite content towards the junction certainly supports the concept that this junction is a 'slide' (the regional Sgorr a'Choise slide, a minor branch of the Ballachulish Slide according to Bailey (1960). The axial trace of the Ballachulish Syncline, according to Bailey, lies within the outcrop of the Ballachulish Limestone. Minor folds in this outcrop show reversals of vergence that would be expected in D1 structures.

The junction to the west between the limestone and the few centimetres of quartzitic Leven Schists, does not exhibit the usual transition from metalimestone into the pelitic top of the Leven Schists and according to Bailey represents the Ballachulish slide on the western limb of the syncline. The exposure of the 'slide', although only one metre in length, shows a slight discordance of bedding orientation across it, between the limestone and the flaggy schist (Figure 16). There is no evidence that it is a much later dislocation that post-dates all the folding, but thin sections would be needed to establish the exact age of movements. On the west side of the western dyke, which obscures the remainder of the outcrop of the 'slide', schistose psammites are typical of the basal part of the Leven Schists; no 'way-up' evidence has been found. Thin-section investigation of the folds and cleavage here would be particularly useful in the delineation of the structural relationships.

Since the Ballachulish Slide occurs on the lower limb of a once recumbent syncline and involves no repetition of strata, Bailey (1960) noted that it would have to have originated as a low-angle normal fault (i.e. a lag) and not as a thrust as would have been associated traditionally with nappe structures. This is a common occurrence in the nappes of the Central Grampian Highlands and led Soper and Anderton (1984) to suggest that such 'slides' might have 
originated as synsedimentary extensional faults. Further research at this locality might help to resolve this debate.

\subsection{Conclusions}

The St John's Church, Loch Leven GCR site contains one of the few exposures across a major dislocation (the Ballachulish slide) of the type that has disrupted many of the major early folds of the Grampian Fold-belt. These 'slides' are of great interest since the faults might have been initiated at the time of sedimentation and developed further during the onset of folding, when they translated the rocks above for many kilometres. The section is well exposed in coastal outcrops that are much visited by student and professional geologists and would benefit from further research.

\section{ONICH DRY RIVER GORGE AND ONICH SHORE SECTION (NN $025 \quad 617-\mathrm{NN} 031 \quad 626$ AND NN 030 614-NN 052 612)}

\section{J.E. Treagus}

\subsection{Introduction}

The two adjacent GCR sites at Onich (Figure 17), especially the almost continuously exposed section on the north shore of Loch Leven, are important for two reasons. Firstly, the sites expose four formations of the Ballachulish Subgroup (Appin Group) in unrivalled sedimentary detail; exposures along the hill to the west of Dubh ghlac, a glacial meltwater channel north-west of onich village, exhibit particularly striking sedimentary structures in the Appin Quartzite. Secondly, clear minor structure observations can be made across a major syncline that has not been complicated by later deformation. The syncline is the regionally important Appin syncline, which can be traced for $50 \mathrm{~km}$ down the west coast of Argyll and within which the Ardsheal Peninsula and Lismore Island GCR sites also lie.

The shore section has been described in detail by Bailey (1960), Roberts (1976), Roberts and Treagus (1977b) and Treagus (1991). It is possibly the most visited section in the whole of the Grampian Terrane, attracting professional geologists, student parties and interested amateurs. It provides an example of a key part of the Dalradian succession, and is used as a mapping exercise and for demonstrating the use of minor structures to deduce the geometry of major structures.

\subsection{Description}

The Onich shore section provides excellent sections across all formations of the Ballachulish Subgroup, except for the Ballachulish Limestone. It is described here from east to west. The oldest formation, the Ballachulish Slates, is well seen in the steep, SE-dipping beds of a small quarry at NN 04946109 to the north of the main road, as well as in shore exposures between NN 04956102 and NN 0465 6103. This formation is typically a 
pyritiferous black slaty pelite with thin semipelite beds that exhibit small-scale graded bedding and cross-lamination indicating younging both to the south-east and to the north-west (for explanation, see structural detail below). Cubes of pyrite, up to $1 \mathrm{~cm}$ across, make the slate very distinctive and roofing slates from here, but mainly from the quarries at South Ballachulish, can be seen throughout Britain. In the Onich area, most of the pyrite has been altered to red-brown pyrrhotite, due to contact metamorphism by the Ballachulish granitic pluton, which crops out $1.5 \mathrm{~km}$ to the south.

The Appin Quartzite is particularly well exposed on the foreshore at NN 0437 6105, where steep, overturned, SE-dipping beds show many examples of trough cross-bedding younging to the north-west (Figure 19). Unfortunately, the junction with the Ballachulish Slates to the east is not exposed and the Appin Transition Formation is not represented. Here the Appin Quartzite is white and gritty, containing pebbles of pink feldspar and creamy quartz in various concentrations. Individual clasts, only slightly deformed, are up to $2 \mathrm{~cm}$ in longest dimension. The shore exposures, on the east limb of the Appin Syncline, are complemented by those on the west limb in the Onich Dry River Gorge GCR site. The latter occur along the track in the valley bottom (Dubh ghlac) and on the hill to its north-west (Druim nan Sleibhean), from NN 02426178 to NN 0314 6254. Numerous small exposures occur, particularly in a drainage ditch to the north-west of the track, exhibiting ripple marks of various dimensions and orientations on NE-striking bedding surfaces that dip at $50-75^{\circ}$ to the south-east. The ripple marks commonly have a wavelength of some $30 \mathrm{~cm}$ but smaller $(2-3 \mathrm{~cm}$ scale $)$ structures are also seen. Most ripples have a sub-horizontal orientation, but others with a down-dip orientation or a steep pitch to the south-west or north-east can be observed locally and produce interference patterns with the former set. Most importantly, 20-30 cm-high cross-sets can be seen (e.g. by the track at NN 02506180 and on the hill at NN 0265 6200), which clearly demonstrate that the beds are right-way-up and young to the south-east. The overall width of the quartzite outcrop suggests that an intermediate-scale fold must occur in the unexposed ground to the east of the track, as shown in Figure 18.

The Appin Limestone, which occupies most of the shore section from its faulted junction with the Appin Quartzite to NN 03906126 (below the school), is a very varied member, which in this area comprises the lower part of the Appin Phyllite and Limestone Formation. For the first $150 \mathrm{~m}$ west of the Appin Quartite it contains much platy pink quartzite, probably repeated in folds, but typically it consists of thin beds of cream-coloured metadolostone (tens of centimetres thick) and lesser white metalimestone with local interbeds of phyllitic semipelite, pink quartzite and psammite. Small-scale graded bedding and cross-lamination in the steep SE-dipping beds are well seen near the faulted junction with the Appin Quartzite and in psammite interbeds $150 \mathrm{~m}$ to the west. These sedimentary structures mostly indicate younging to the southeast, so that the beds are right-way-up (for explanation, see structural detail below). A pink microdiorite dyke at NN 03956125 
marks the core of an anticline in metalimestone, exhibiting southeast younging on its south-east limb.

For a further $200 \mathrm{~m}$, on the north-west limb of the anticline, thin metalimestones are seen in gradational contact with the upper part of the Appin Phyllite and Limestone Formation, here called the Appin Phyllite. The latter consists of grey, phyllitic semipelites containing numerous intercalations of schistose calcsilicate rock and purer metalimestone as well as flaggy quartzite. The Appin Phyllite to the west is exposed continuously between NN 03716127 and NN 03186129 (below the Onich Hotel). Centimetre-scale graded bedding and cross-laminations are common and these structures show consistent younging to the north-west in the overturned, steeply SE-dipping beds. SE-verging minor folds of thin metalimestones are seen from NN 03716127 to the centre of the main synclinal fold, which is marked by some $50 \mathrm{~m}$ of younger dolomitic metalimestone at NN 03426131 (Figures 17, 18). The excellent exposures at the far west end of the section, below the hotel, show the same sedimentary structures, including slump-folds, younging to the east in shallower SE-dipping beds on the west limb of the syncline. Isolated exposures of Appin Phyllite, Appin Limestone and Appin Quartzite are seen on the west limb, at NN 03026140 (south of the road), NN 02596146 and NN 02416153 (north of the road), respectively.

As demonstrated above, the gross stratigraphical repetition across the site, together with change in the dip of bedding and the abundant sedimentary way-up indicators, clearly reveals the presence of a major tight syncline, with an overturned south-east limb. This is interrupted by one conspicuous intermediate-scale anticline at NN 03936125 and a faulted-out syncline as described above. In addition, the shore section presents an unusual wealth of first phase (D1) minor structures (folds and cleavage/bedding relationships) that can be used to demonstrate the presence and geometry of the major syncline, the anticline and several other smaller-scale folds, which are described below from east to west (Figures 17, 18).

The outcrops of the Ballachulish Slates at the east end of the shore section are too isolated to be useful in the interpretation of the major first fold geometry. However, these outcrops, do contain reversals of younging and of cleavage/bedding relationships that demonstrate the presence of intermediate-scale Fl folds. The exposures also contain a later crenulation cleavage and minor folds, which indicate that a major synform is to be expected to the east of the GCR site.

Proceeding westwards, the Appin Quartzite outcrop at the eastern end of the shore section is isolated by a fault or slide along its western margin with the Appin Limestone, marked by a few centimetres of platy schists with lens-shaped quartz-veins. The dolomitic metalimestone a few metres west of the fault contains both E- and W-verging, vertically-plunging, isoclinal folds; Wverging minor structures in the E-younging rocks for $150 \mathrm{~m}$ to the west show that a major- or intermediate-scale syncline must be replaced by the fault, as illustrated in the cross-section of Figure 18 . 
On the hill to the north-east of the shore section, at NN 4096 6175, a 10 m-thick psammitic bed within the Appin Limestone closes in the probable core of this syncline (J.L. Roberts, personal communication, 1977). The intermediate-scale anticline at NN 0393 6125 can be identified both from exposure of its hinge and from changes in minor fold and cleavage vergence in the Appin Limestone for $100 \mathrm{~m}$ around the hinge area. To the west, at NN 0375 6128, another fold-pair with a $20 \mathrm{~m}$ wavelength can be identified from vergence reversals in beds transitional into the Appin Phyllite.

On the foreshore, from NN 037613 westwards, well-developed minor structures in the Appin Phyllite consistently verge to the east, indicating that a major syncline lies to the west (Figure 18); the hinge of this fold can be identified in metalimestones at NN 0338 6130. Excellent minor structures can then be seen, verging west, away from the hinge, in the remaining $150 \mathrm{~m}$ of exposure. Minor folds throughout the shore section plunge on average at $10-30^{\circ}$ to the south-west, although locally they plunge at up to $50^{\circ}$ to the south-west and at low angles to the north-east. A penetrative phyllitic cleavage, axial planar to the minor folds, dips at $60-80^{\circ}$ to the south-east. A down-dip stretching lineation is well seen on the cleavage planes in the phyllitic rocks, emphasized by the orientation of millimetre-long biotite crystals.

\subsection{Interpretation}

The Onich GCR sites provide good type examples of the lithologies and of sedimentary structures within the Ballachulish slate and Appin Quartzite formations. The exposures of the Appin Limestone and the Appin Phyllite and their transitional junction are also unrivalled for their clarity and detail. In contrast to exposures of these two stratigraphical units farther to the south-west (e.g. at the Arsheal Peninsula GCR site), at Onich they exhibit considerable interleaving of phyllitic rocks, metadolostone and grey metacarbonate rock as well as of local psammites. Some of this interleaving can be attributed to tight interfolding (see below) but it did lead Bailey (1960, pp. 37-38) to abandon the distinction of the two units and in most areas they are now combined formally as the Appin Phyllite and Limestone Formation. A separate Appin Limestone Member is recognized only where it can be clearly distinguished.

Structurally, there can be no doubt that the minor folds and cleavage are of the first regional generation (D1) and they clearly demonstrate that the major syncline, the Appin Syncline of Bailey (1960) is of this age. Although strictly this D1 age can only be demonstrated from thin section examination (Roberts, 1974; Treagus, 1991) the cleavage as viewed in the field is penetrative and the folds do not refold any earlier cleavages, lineations or folds.

It should be noted that Hickman (1978) regarded the Appin Syncline as a D2 structure, partly on regional considerations and partly from comparisons with observations on the structure farther to the south-west (see the Ardsheal Peninsula and Lismore Island GCR site reports). His explanation for the penetrative nature of his 'S2' slaty cleavage was that the regional first cleavage, seen in the 
schists to the east (see the Rubha Cladaich and Nathrach GCR site reports) has been overprinted to become unrecognizable at Onich.

\subsection{Conclusions}

The two GCR sites at Onich are important for two reasons. Firstly, they contain unrivalled sections of four stratigraphical units of the Ballachulish Subgroup-the Ballachulish Slates, the Appin Quartzite, the Appin Limestone and the Appin Phyllite. These are rich in detail revealing the nature of the original sediments, particularly structures showing the original order of deposition. Secondly, they contain a wealth of minor structures (folds and cleavages) resulting from the deformation of the sedimentary rocks. The latter structures can be used to demonstrate the D1 relative age, position and shape of a major fold having an outcrop width of several kilometres. This Appin syncline is a key component of the overall structure of the Grampian mountain belt.

\section{ARDSHEAL PENINSULA}

\section{(NM 961 555-NN 007 579)}

\section{J.E. Treagus}

\subsection{Introduction}

The Ardsheal Peninsula GCR site, on the south-east side of Loch Linnhe, gives a superbly-exposed section across five stratigraphical units in the Appin Group, from the Appin Transition Formation of the Ballachulish Subgroup, up into the Cuil Bay Slates of the Blair Atholl Subgroup. Although the whole outcrop width of the F1 Appin Syncline is represented on the peninsula, the almost continuous clean coast section described here is the on the northwest limb. Minor structures related to the major F1 fold are exceptionally well exposed, and minor structures belonging to the regional D2 phase are superimposed on the early structures in the eastern part of the GCR site.

The area of the GCR site was described in general by Bailey (1960), who was the first to recognize the major structure as an upward-, NW-facing primary syncline. It was subsequently described in detail by Treagus and Treagus (1971), after Bowes and Wright (1967) had given a very different account of the structure in their examination of the setting of the igneous rocks of the area. The latter are discussed in site reports in the Caledonian igneous rocks of Great Britain GCR volume (Stephenson et al., 1999).

\subsection{Description}

The five most instructive areas of exposed Dalradian rocks in this GCR site are situated along the south-west and north-west coasts of the peninsula (Figure 20, localities 1-5). The youngest formation, the Cuil Bay Slates, is exposed at locality 1, the type locality for this formation on the north-west side of Cuil Bay, between NM 97635539 and NM 9724 5544. At the east end of these exposures, on 
a small peninsula below a fishing croft, centimetre-thick graded beds of grey silt to black mud (now slaty semipelite and pelite) are particularly well seen. These beds are folded into $3 \mathrm{~m}-$ wavelength, tight to open, upright folds, which plunge to the south-west, face upwards and verge to the north-west (Figure 21b). They have an axial-planar slaty cleavage dipping at 50-60 to the south-east and a stretching lineation of elongate chloritemuscovite stacks, which pitches steeply to the north-east on the cleavage. Elsewhere, the slaty cleavage is strongly affected by a second generation of open folds, particularly well seen on the south-east side of this small peninsula, Rubha Beag. These folds also plunge to the south-west and have a north-west vergence, but they are related to a crenulation cleavage, which dips at $60-70^{\circ}$ to the north-west and cross-cuts the earlier folds. The effect of this folding is to rotate the earlier slaty cleavage into flatlying attitudes and, locally, to refold the earlier fold-set. The first cleavage surfaces are strongly crenulated and kinked; some kinks are due to original refraction through the semipelite and pelite beds, others result from the second deformation and yet others are related to later deformation associated with the intrusion of dykes.

The junction with the next oldest stratigraphical unit, the Appin Phyllite, is not exposed; but this unit occupies the whole of the next small peninsula to the west, Rubha Meadhonach (locality 2). Bedding, which is less easy to see in these rather uniform grey phyllitic semipelites, dips steeply to the south-east and locally exhibits upward-younging graded units and ripple-drift crossbedding, particularly on the north-west side of the outcrop. The first cleavage dips steeper to the south-east than the bedding, and intersections plunge gently to the south-west. The second cleavage and folds are not strongly developed, but the intersection of the second cleavage with the first plunges at varying angles to the north-east. Kink bands, commonly conjugate, are well developed.

The westernmost subsidiary peninsula of the GCR site, Rubha Mor, exposes a further three stratigraphical units, the Appin Limestone and the Appin Quartzite, as well as the distinctive transitional beds to the Ballachulish Slates (the Appin Transition Formation). The Appin Limestone and its steep SE-dipping junction with the Appin Quartzite are exceptionally well displayed on the south-east coast of Rubha Mor between NM 966557 and NM 963556 (locality 3). The youngest beds, on the seaward side, are mixed metacarbonate rocks, quartzites, phyllitic semipelites and psammites (Figure 21b), followed downwards by a clear sequence of white quartzite, grey metacarbonate rock, cream dolomitic metalimestone and phyllitic semipelite, each a metre or two thick, before the wellexposed junction with the Appin Quartzite is reached high on the cliff. These latter beds are seen in a spectacular fold-pair in a 15 m-long section at the south-west end of their outcrop. Here, disharmonic minor folds and refracting penetrative axial-planar cleavage are beautifully displayed; the vergence of minor folds and cleavage/bedding is to the north-west and the plunge is $20-40^{\circ}$ to the south-west (Figure 21b).

The Appin Quartzite consists of thick-bedded (up to $2 \mathrm{~m}$ ) white quartzite with quartz and feldspar pebbles up to $20 \mathrm{~mm}$ across in a 
gritty matrix; the clasts are only weakly elongated in a poorly developed cleavage in the finer grained beds. The quartzite commonly displays cross-beds younging to the south-east, which are especially well-seen near the top of the formation at NM 96405565 (locality 3) and near the base on the north-west side of the promontory at about NM 968557 (locality 4). The Appin Transition Formation is seen on the shore of Loch Linnhe from about NM 963558 to NM 971565 (locality 5). These steeply SE-dipping beds of striped psammites, semipelites and graphitic pelites display a variety of SE-younging sedimentary structures including small-scale grading, ripple-drift cross-bedding, load structures, slump-folds and sedimentary dykes. Cleavage in the pelitic beds is penetrative. The vergence of minor folds and cleavage/bedding intersection is to the north-west and the plunge is $10-30^{\circ}$ to the south-west.

\subsection{Interpretation}

All of the stratigraphical units that crop out at localities 1-5 exhibit the same north-west vergence of both the earliest folds of bedding and of the cleavage/bedding intersection related to those folds. According to Bailey (1960), Voll (1964) and Treagus and Treagus (1971), they lie on the north-west limb of the regional fold, the Appin Syncline, which all these authors agree is one of the early (D1) fold-set. The hinge-zone and south-east limb of this fold, affecting the Appin Phyllite and Limestone Formation, is best seen, up plunge to the north-east, in the Onich GCR sites. A generalized structural profile of the fold as it affects the rocks of the Ardsheal and Onich GCR sites is illustrated in Figure 18, which shows the five locations discussed above. The later folds and associated crenulation cleavage, which are seen at Ardsheal on the north-west limb of the Appin Syncline, but also on its southeast limb at Onich, show a consistent north-west vergence on both limbs. These folds belong to the regional D2 phase of Treagus and Treagus (1971) and are subsidiary to the major Stob Ban Synform, seen to the east (see the Tom Meadhoin and Doire Ban and Stob Ban GCR site reports).

The paper by Treagus and Treagus (1971) contradicted the earlier view of Bowes and Wright (1967) that the syncline is a third-phase structure associated with the retrograde metamorphism in the area. Bowes and Wright proposed that 'elongate compositional blebs' and small isoclinal fold noses in semipelites within the Appin Phyllite are evidence of an earlier D1 phase. Mica flakes that cut across these earlier features were said to be attributable to a D2 phase. The lineation resulting from the mica flakes was said to be folded around the Appin Synform, which was therefore interpreted as a D3 phase. No locations nor detailed measurements of these structures were given and no evidence was found by Treagus and Treagus (1971), or has been found since, to support these views. Importantly, thin-section examination of the pelites from the Ardsheal Peninsula GCR site has shown that the penetrative cleavage that is axial planar to the dominant minor folds and to the major syncline was developed as part of the regional, progressive, chlorite-muscovite metamorphism. 


\subsection{Conclusions}

At the Ardsheal Peninsula GCR site it can be demonstrated that the Appin syncline, one of the major folds in the western part of the Grampian Fold-belt, was produced as part of the earliest deformation of these rocks. The site provides superlative examples of the minor folds produced by this deformation as well as evidence of the effects of a later period of deformation, superimposed on the earlier one. The site also provides excellent clean exposures of five stratigraphical units in the upper part of the Appin Group with clear evidence of the nature of the original sediments; it contains the type locality of one of them-the cuil Bay slates. The site is a necessary complement to the GCR sites at Onich to give a complete cross-section of the Appin syncline. The site is of exceptional importance educationally and is used extensively by undergraduate parties and students undertaking mapping projects.

\section{SOUTH COAST, LISMORE ISLAND \\ (NM $798 \quad 386-\mathrm{NM} 784 \quad 366-\mathrm{NM} 813 \quad 383$ )}

\section{J.E. Treagus}

\subsection{Introduction}

The South Coast, Lismore Island GCR site comprises the coastal exposures and much of the inland outcrop at the south-western end of the elongate island of Lismore to the north of Oban (Figure 22). It is important primarily for its unique exposures of the Lismore Limestone, one of the formations of the Blair Atholl Subgroup of the Appin Group. The substantial middle and upper divisions of the formation are represented; these comprise dominant metalimestone with lesser slaty pelite and transitional facies. Structurally, the site lies in the core of the F1 Appin Syncline, a major structural feature of the western side of the Grampian Fold-belt, which is also the focus of interest of the Ardsheal Peninsula and Onich GCR sites, at progressively lower structural levels. On Lismore, the D1 structure is strongly modified by D2 structures.

The geology of the island was described briefly in the Geological Survey memoir by Lee and Bailey (1925) and both the stratigraphical and structural features have been described subsequently in great detail by Hickman $(1975,1978)$. The following descriptions are largely based upon the work of Hickman, with additional observations by the author.

\subsection{Description}

The Lismore Limestone Formation is estimated to be about $1 \mathrm{~km}$ thick and the sequence of blue-grey metalimestone and minor black slaty pelite has been divided into fifteen members by Hickman (1975). These members can be grouped into three distinct lithological 'units'. Of these only the middle and upper units are exposed within the area of the GCR site (Figure 22). The middle unit (about $450 \mathrm{~m}$ thick) comprises three metalimestone-pelite cycles, each containing 
a lower metalimestone member (50-200 m thick), a transitional banded argillaceous metalimestone member (20 m thick) and an upper pelite member (10-20 $\mathrm{m}$ thick). The metalimestone is blue-grey, recrystallized and to varying degrees graphitic and pyritiferous, with partings at $5-20 \mathrm{~cm}$ intervals. The transitional beds have individual beds, typically $3-10 \mathrm{~cm}$ thick, which are graded. The pelite members are grey, highly carbonaceous and pyritiferous with a low carbonate content. The upper unit has a lower metalimestone member $(300 \mathrm{~m})$ and an upper banded argillaceous metalimestone member $(50 \mathrm{~m})$, which rarely preserves festoon structures and load casts. Cross-stratification is rarely preserved in the metalimestones and isoclinal folds in the pelites and argillaceous metalimestones might be slump structures.

The whole sequence across the upper unit and the upper two cycles of the middle unit may be seen within the GCR site in a traverse of the craggy inland outcrops from Bagh Clach an Dobhrain (NM 799 377) to Miller's Port (NM 812 372). Excellent clean exposures of metalimestone are seen all around the coast on the wave-cut platforms, those of the upper unit on the north-west side of the island (e.g. at NM 789 364) and those of the middle unit on the south-east side (e.g. south-west of Miller's Port at NM 812 372). The banded argillaceous metalimestone of the upper unit is well seen at Bagh Clach an Dobhrain (at NM 799 375) and argillaceous metalimestones and pelites of the middle unit are seen inland on the ridge of Druim na Curra, near Fiart Farm (at NM 802369 and NM 803370 respectively). The continuous 'slate belt' that passes through the Loch Fiart area, identified on both the original (1923) and the more-recent (1992) Geological Survey maps, was originally regarded as the eroded crest of an anticline, with the pelite underlying metalimestone everywhere on the island (Lee and Bailey, 1925). However, Hickman (1978) demonstrated that the pelite is an interbedded part of the stratigraphical succession.

The structure of the metalimestones within the GCR site is dominated by upright asymmetric tight to open folds with a wavelength of $0.5-20 \mathrm{~m}$ (Figure 23). The folds typically plunge at 20-50 to the south-west and have a strongly developed, steeply dipping, axial-planar crenulation cleavage in the slightly argillaceous metalimestone beds. Stretched pyrite blebs pitch steeply north-east on the cleavage. This cleavage is axial planar to folds of a bedding-parallel phyllitic cleavage. Hickman (1978) mapped a major antiform-synform fold-pair ( $A$ and $B$ on Figure 22) related to a change in vergence of minor folds associated with the dominant later deformation. Hickman (1978) also drew the trace of a tight syncline through the site area (fold C on Figure 22), related to the earlier deformation. The evidence for the early syncline lies in a closure of the stratigraphical units in the area to the north-east of the GCR site, where it is cross-cut by the later folds and cleavage (see below).

\subsection{Interpretation}

The detailed stratigraphical succession within the Lismore Limestone Formation contains variations between pure metalimestone and pelite very similar to those of the Blair Atholl Dark Limestone 
and Dark Schist Formation of the Strath Fionan GCR site, with which it can be correlated confidently (Lee and Bailey, 1925). The obvious differences between the two GCR sites are the stronger representation of transitional facies between pure metalimestone and pelite in the former and of thicker pelite members in the latter. Unsurprisingly, the Lismore GCR site, with its lower grade of metamorphism, reveals more sedimentary structures, such as festoon bedding, cross-bedding and load casts. The common graded bedding however, which might be expected to survive the higher grade metamorphism, has not been recorded in the Schiehallion area.

The main feature of structural interest on Lismore is the NEtrending syncline that crops out through the centre of the GCR site and the Loch Fiart area (Figure 22, fold C). This fold was assigned to D1 by Hickman (1978) on the basis that the dominant D2 minor structures are superimposed across the stratigraphical repetition that marks the position of the Dl fold. Hickman did not provide vergence data to support the position or age of the syncline within the GCR site area. However, in the area that lies on the south-east limb of this fold, the phyllitic cleavage is seen (though rarely) at a small angle to bedding and axial-planar to small, 10 cm-amplitude isoclines (e.g. at Miller's Port, 812372). The paucity of vergence information on these folds and cleavage across the trace of the syncline does not allow confirmation of the position or age of the syncline. However, the vergence of the later folds is consistently towards the north-west across the trace of the fold (see the cross-section on Figure 22) and the steeply SE-dipping rocks on its south-east limb are consistently inverted and face down on the steeper dipping later cleavage.

The trace of syncline $C$ in the north of the island, as drawn by Hickman (1978), can be extrapolated to the north-east, through the Island of Shuna directly into that of the F1 Appin Syncline at Cuil Bay and Onich (see the Ardsheal Peninsula and Onich GCR site reports). The vergence and plunge of the D2 structures is consistent with observations of their relations to the Appin Syncline at the above sites, and to the major F2 Stob Ban Synform to the east (see also the Tom Meadhoin and Doire Ban and Rubha Cladaich GCR site reports). Hickman (1978), however, considered that the Appin Syncline, which he regarded as a D2 structure, should be correlated with the major F2 synform A on Figure 22. However, the trace of this fold, as shown by Hickman (1975) in the north of Lismore, does not extrapolate well with the projected trace of the Appin Syncline from Ardsheal through the island of Shuna.

\subsection{Conclusions}

The South coast, Lismore Island GCR site is the type locality for the Lismore Limestone Formation of the Blair Atholl Subgroup, which can be examined in detail in superb coastal and inland exposures. The information gained from the cycles of limy and muddy sedimentation that made up the formation is essential to the understanding of the development of the shallow shelf on which the early Dalradian sequence was deposited, particularly in comparison with other sites in the area and elsewhere in the Central Grampian 
Highlands. The site also provides, from its two sets of minor structures, valuable evidence for the location, identity and geometry of major $\mathrm{F} 1$ and $\mathrm{F} 2$ folds in the region, which play a fundamental role in the development of the Grampian Mountain-belt.

The Appin Syncline, the most important major F1 fold on the northwest side of the mountain-belt, can be traced through this GCR site and its geometry can be established. The later D2 folds and cleavage are particularly well displayed and demonstrate a consistent geometry down this side of the mountain-belt from the GCR sites at Onich and the Ardsheal peninsula into the Lismore Island GCR site. The site has great potential for future stratigraphical as well as structural research.

\section{CAMAS NATHAIS (NM $874 \quad 370-N M \quad 875 \quad 382$ )}

\section{P.W.G. Tanner}

\subsection{Introduction}

This GCR site lies $7 \mathrm{~km}$ north of Oban in the Benderloch area and is located on the raised beach platform around the head and south-east side of a narrow inlet of the sea, Camas Nathais. Well-scoured rock exposures display an excellent example of a ductile fault, the Benderloch slide (Litherland, 1980). The slide contact, which is the main feature of interest at this locality, is well exposed for a strike distance of over $100 \mathrm{~m}$ and both the plane of movement, and the structures in the rocks on either side of it, can be examined in three dimensions. Such contacts are rarely seen in the Highlands, and this example is exceptional for its clarity, and for the quality of the rock exposure.

For many years the geology of this area was the focus for a fundamental geological debate between the followers of E.B. Bailey (1922, 1953), who interpreted the abrupt east-west changes in rock type seen on a regional scale in terms of nappe tectonics, and those who supported G. Voll (1964), who invoked extreme local facies changes. Bailey considered that radically different stratigraphical successions had been brought together by syntectonic faults called slides, the slide at Camas Nathais being correleated with a major tectonostratigraphical dislocation in the south-west and Central Grampian Highlands, later named the 'Iltay Boundary Slide' (Stephenson et al., 2013a). On the other hand, Voll concluded that the lithological differences seen across the area are of sedimentary origin, and that the rocks constitute a single, unbroken succession. The situation was resolved by Litherland (1980, 1982) who, by means of detailed field mapping, demonstrated that the so-called 'Banded Leven Schists' of Bailey (1922) could be subdivided into the 'true' Leven Schists of the lower Appin Group to the west, and rocks belonging to the lower part of the Argyll Group to the east. However, he confirmed that these two parts of the Dalradian succession had been brought together by a major tectonic break, which he named the Benderloch Slide. 
At the head of Camas Nathais, the Benderloch Slide appears to place part of the Ballachulish Limestone (Appin Group) against the base of the Argyll Group, so excising a significant part of the Appin sequence. The plane of movement is marked both by a strong lithological contrast between black graphitic slaty pelites on one side and orange-yellow metadolostone and pale grey quartzite on the other, and by a zone many metres thick of sheared rocks that display a pronounced stretching lineation. The tectonic break is inferred to have developed early in the tectonic history of the area, with both the fault plane and the adjacent rocks having been subjected to several phases of later movement. The Benderloch Slide is no longer regarded as part of an intraregional 'Boundary Slide', but it can be correlated with the Ballachulish Slide found farther north (Rast and Litherland, 1970). The GCR site reports for St John's Church and for Tom Meadhoin and Doire Ban also discuss the possibility that the slide might be of synsedimentary origin and was only re-activated during later 'tectonic' events.

\subsection{Description}

The geological setting of this site is shown on Figure 24, with the Benderloch Slide being strikingly exposed at (NM 87626 37938), near the head of the bay (Figure 25). The structural break was first recognized by Bailey, who stated that '...on the western side of Garbh Ard the margin of the quartzite, where exposed upon the foreshore, is separated from the Appin Limestone by a few feet of black slates and limestone but, unfortunately, there are signs of considerable movement having taken place near the junction line' (in Kynaston and Hill, 1908, p.36). Bailey later re-assigned the rocks described above as 'Appin Limestone', to the Ballachulish Limestone.

The slide plane dips at $42-46^{\circ}$ to the north-west and lies within a sequence of rocks that all dip steeply $\left(50-75^{\circ}\right.$ ) in a north-westerly direction. The junction between a 0.5-1.0 m-thick band of boudinaged, discontinuous orange-weathering metadolostone below, and a black pelite-metalimestone unit above, marks the actual dislocation (Figure 26). When the slide plane is viewed at beach level from the north-west, flat surfaces of intensely lineated quartzite are seen in erosional windows carved out of this metadolostone sheet.

On the Fionn Ard peninsula, north-west of Camas Nathais, there is a wide outcrop of dark, finely banded semipelitic and pelitic rocks belonging to the Leven Schists. At the head of the bay, units of grey-green phyllitic semipelite and cream-coloured, finely laminated metadolostone structurally underlie these rocks, but the contact is not exposed (Figure 24). The metadolostone weathers orange-brown and forms thick units, one of which was formerly quarried at the site, but also occurs interbedded on a metre-scale with semipelite. The lowermost $10 \mathrm{~m}$ or so of rock above the slide consists of dark grey to black phyllitic rocks, which contain a band of black metalimestone less than a metre thick (L on Figure 25). The metadolostone-'phyllite' sequence, and the dark 'phyllite' and metalimestone, have been correlated, respectively, with the lower and upper parts of the Ballachulish Limestone Formation (Bailey, 1922; Litherland, 1980), but Litherland (1982) 
subsequently correlated the dark phyllitic unit with the much younger Lismore Limestone.

The rocks below and south-east of the slide plane consist largely of quartzite and were subdivided into the Baravullin Quartzite, Castle Dolomitic Flags, and Tralee Bay Quartzite by Litherland (1980). The Baravullin Quartzite is pale grey to white in colour and occurs in the footwall immediately below the slide. It has been intensely brecciated, but evidence of crudely defined bedding planes can still be detected, defining units up to $40 \mathrm{~cm}$ thick separated by thin phyllitic layers or films. The quartzite is underlain structurally by the Castle Dolomitic Flags, which form the spine of the Garbh Ard peninsula and consist of a banded alternation of buff-coloured quartzite ribs with dolomitic semipelite and greenish phyllitic rock.

A stretching lineation is strongly developed in rocks adjacent to the slide contact (inset to Figure 26), and dominates the fabric for a distance of some $10 \mathrm{~m}$ into the hanging-wall semipelites and pelites. It has a consistent orientation and plunges at an average of $34^{\circ}$ to $352^{\circ}$. The orange-weathering metadolostone that lies immediately below the slide plane has been boudinaged, with boudin necks aligned normal to the stretching lineation. This lineation is deformed by a crenulation cleavage that affects rocks on both sides of the slide. Evidence for later movement on the fault plane is given by a veneer of silicified fault breccia, up to $15 \mathrm{~cm}$ thick, found in contact with the metadolostone (Litherland, 1982). It contains fragments of randomly orientated, crenulated slaty rocks similar to those found adjacent to the slide.

In the immediate footwall to the slide, beneath the metadolostone bed, there is a 1 m-thick zone of highly fractured quartzite, with numerous quartz veins, underlain by a considerable thickness of pervasively fractured rock. Throughout this fractured zone the quartzite consists of interlocking fragments 1 to $2 \mathrm{~cm}$ across, separated by deeply weathered seams and fissures, which are of possible pressure-solution origin. In some beds the fragments are equidimensional, but in general they are crudely aligned at a moderate angle to bedding. In three dimensions they have extremely flattened and elongated pancake shapes, and have a veneer of white mica on their surfaces. Where minor folds are developed in these rocks, the fragments are aligned roughly parallel to the axial planes of the folds and to the penetrative cleavage in the moremicaceous bands, so that they appear to define a rough cleavage. This relationship is seen to within $2 \mathrm{~m}$ of the slide plane.

Deeper into the footwall, bedding in the Baravullin Quartzite and Castle Dolomitic Flags is cut by a less-steep penetrative main cleavage dipping to the south-west, which is in turn cut and reworked by a crenulation cleavage that dips at $20-35^{\circ}$ to the north-west, and is associated with minor folds up to a few tens of metres in wavelength.

In the hanging wall, metre-scale upright folds are associated with a penetrative axial planar cleavage in the more-micaceous bands, which dips steeply to the north-west. In places there is clear evidence that a generation of minor folds, with an axial-planar penetrative cleavage, pre-dates the main cleavage. These early folds are clearly seen in the laminated metacarbonate rocks, which 
develop thin axial-planar quartz veins. As in the footwall rocks, the main cleavage is cut by a spaced crenulation cleavage, which dips at a low angle $\left(30-40^{\circ}\right)$ in the same direction and is accompanied by minor folds plunging to the south-west. Calcareous bands in the phyllitic rocks preserve the main cleavage but are commonly reduced to a series of sigmoidally shaped lenses by the development of a cross-cutting, later, spaced pressure-solution cleavage having the same geometry as the crenulation cleavage in the phyllitic rocks.

\subsection{Interpretation}

The pelites, semipelites, psammites and dolomitic rocks in the hanging wall to the slide at Camas Nathais (units C to F, Figure 25) have been correlated with the lower part of the Ballachulish Limestone by previous workers, and the dark phyllitic pelite and black metalimestone beneath them (unit D, Figure 25) with either the upper part of the Ballachulish Limestone (Bailey, 1922; Litherland, 1980), or with the Lismore Limestone (Litherland, 1982).

South-east of the Benderloch Slide, the Barravullin Quartzite, Castle Dolomitic Flags and Tralee Bay Quartzite can be correlated with elements of the Islay Subgroup on Islay and Jura. Farther to the north-east, the Tralee Bay Quartzite is overlain by the Selma Black Slates and the Selma Breccia (Figure 24), rocks equated respectively with the Jura Slate (see the Kilnaughton Bay GCR site report) and Scarba Conglomerate (see the Lussa Bay GCR site report). Crucial to this assignment of rocks south-east of the slide to the Argyll Group is the correlation of the Baravullin Boulder Bed with the Port Askaig Tillite (see the Garvellach Isles GCR site report). The Baravullin Boulder Bed is not exposed at Camas Nathais but, according to Litherland (1980), it crops out inland $3 \mathrm{~km}$ to the north-east of the GCR site, and on the southeast side of the projected line of the slide (Figure 24). A thin sliver of the Islay Limestone (locally called the Baravullin Dolomite) was also reported from this locality. These stratigraphical correlations suggest that (1) the Benderloch Slide lies at, or close to, the base of the Argyll Group, and (2) following Litherland (1980), most of the Ballachulish Subgroup, and all of the Blair Atholl Subgroup, are cut out at the line of the slide.

Evidence from the area around Loch Creran, well to the north of Camas Nathais, shows that the main movement on the Benderloch slide occurred before the first deformation. The latter affected both the footwall and hangingwall, and was responsible for the formation of the early penetrative cleavage. In the Loch Creran area the S1 slaty cleavage cuts across the plane of the slide (Voll, 1964) and the slide is locally folded by map-scale Fl folds (Litherland, 1982).

The Dalradian sediments preserved in this area were laid down in an unstable environment at the margin of a large basin and the slide could represent mass movement of part of the bedded sequence down the submarine slope, into the developing basin. Evidence for basin-margin instability and slumping of material at a slightly 
later time is clearly preserved in the form of the Selma Breccia described in the Port Selma GCR site report. The evidence that brecciation of the quartzite in the footwall to the slide at Camas Nathais occurred before an early phase of deformation is compatible with these conclusions, although the relationship of the earliest penetrative cleavage to the slide cannot be demonstrated directly. However, the stretching lineations associated with the slide movement are deformed by the low-angle, NW-dipping crenulation cleavage that affects both the footwall and hangingwall rocks at this site, so placing a minimum age on the main slide movement. Some rejuvenation of the faulting then occurred after the crenulation event, as is witnessed by disorientated fragments of already crenulated phyllitic pelite and semipelite in the late fault breccia.

New fieldwork carried out to date suggests that the rocks on both sides of the Benderloch Slide have been affected by the same sequence of structural events. Correlation of the early penetrative cleavage and the crenulation cleavage between footwall and hanging wall, and with the D1-D4 deformation phases documented in the wider area by Litherland (1982) is premature. It needs confirmation by a more-complete study of the geometry of the structures, and of the tectonic fabrics in thin section. The stratigraphical correlation of the hanging wall sequence with the known Dalradian succession in the area, the nature of the fault rocks, and the shear sense on the slide plane, also remain to be determined.

\subsection{Conclusions}

At Camas Nathais a large fault, termed the Benderloch Slide, has juxtaposed two different parts of the Dalradian sequence. As the rocks within such fault-zones are generally physically weaker than the country rocks, they are easily removed by erosion when they become exposed at the Earth's surface. In this way, crucial evidence is destroyed that could have been used to determine the nature and amount of movement that had taken place on the fault, and the relative timing of the event. Hence, it is only in exceptional cases, such as are seen at this GCR site, that the zone of crushed and distorted rocks that forms at the contact between the two fault blocks is preserved. This site is also of historical importance as there has been a dispute over the nature and significance of the junction between the two groups of rocks at this locality, since E.B. Bailey first identified it in 1908.

It is important to know whether the fault movement occurred early in the history of deformation, when the fault would be subjected to later folding and overprinted by the main cleavage, or later, when it would cut and displace the fold structures themselves. Field evidence from outwith the GCR site, as summarised above, indicates that the first movement on the fault took place before the main deformation had begun, probably at about the time that the sediments were being laid down. This plane of weakness could have provided a focus for later, repeated movement, as found at Camas Nathais, and its origin is in stark contrast to that of the selma Breccia, described in the Port Selma GCR site report. 
This site has considerable potential for further research. The fault rocks are well preserved, despite later folding and metamorphism, and by studying the structural fabrics under the microscope it should be possible to determine the relative direction of movement of the two blocks. Many outstanding questions still remain to be resolved before we have a clear idea of the geometry, timing, and causes, of the displacements on this major slide.

\section{PORT SELMA, ARDMUCKNISH (NM 902 381)}

\section{P.W.G. Tanner}

\subsection{Introduction}

The Port Selma GCR site consists of a small rocky headland, and the ridge inland from it, crowned by the ancient vitrified hill fort of Dun MacSniachan. It lies south of Port Selma, near Benderloch (Figure 27), and is well known for its excellent coastal exposures of the Selma Breccia. Port Selma is one of a handful of localities in the Dalradian Supergroup from which possible microfossils have been reported.

The Selma Breccia belongs to the Easdale Subgroup and has been correlated with the Scarba Conglomerate on Jura (see the Lussa Bay and Kinuachdrach GCR site reports). It consists of five metabreccia units, the uppermost of which contains numerous blocks of limestone of a type that is exotic to the local area. It was from this unit, and the interbreccia bed beneath it, that Litherland (1975) recorded the presence of the fossil remains for which the locality is best known. These microfossils, called oncolites and catagraphs, are of uncertain origin but could be fossil algae or bacteria.

This GCR site provides an important insight into the nature of the depositional environment found at the margin of the Dalradian basin during early Argyll Group times, shortly after a major late Neoproterozoic (Port Askaig) glacial episode. It also serves as an excellent case study for establishing the criteria that may be used for distinguishing between breccias of sedimentary and tectonic origin, a topic of considerable debate wherever such rocks occur worldwide. The present case is of particular significance and interest because the breccia has been deformed and metamorphosed subsequently during an orogenic event, so obscuring some of its original sedimentary features, and making diagnosis more difficult. It was first described by Flett (in Kynaston and Hill, 1908) who interpreted it as a 'crush breccia', a rock formed by the in-situ brecciation of originally intact rock layers. A detailed field and microscopic study of the formation was made subsequently by Litherland (1970, 1975) who concluded that it had formed by submarine slumping of sediment. 


\subsection{Description}

The rocks at this GCR site consist of the Selma Black Slates overlain by the stratigraphically younger Selma Breccia (Litherland 1970, 1975); the regional geological setting is shown on Figure 24. The rocks are affected by several upright folds of bedding, but overall the succession dips and youngs to the south-east.

The Selma Black Slates, make up the northern part of the site (Figure 27), and consist largely of slaty pelites that contain thin layers and lenses of metamorphosed siltstone, sandstone, calcareous gritty sandstone and limestone, with some of the carbonate lenses being of possible diagenetic origin. The bedded metasediments commonly show the effects of slump folding, with folds reaching over a metre in amplitude; in places such movements culminated in the formation of 'balled-up' masses. The synsedimentary origin of these structures is, in some cases, confirmed by the observation that the base of an overlying bed cuts across the eroded tops of the slump structures. In addition, their pretectonic nature is revealed by the fact that both limbs of such folds are seen in thin section to be transected by the early (S1) cleavage.

A package of gently dipping gritty metasandstone beds, each up to $30 \mathrm{~cm}$ thick and showing clear, right-way-up graded bedding is found at NM 902 381. The dark slaty metamudstones making up the lower part of this member pass up into a thick unit of pebbly metamudstone (Figure 27). The metamudstone contains fine, barely visible, silty laminations and some lenses of gritty metasandstone, as well as isolated boulders up to $24 \mathrm{~cm}$ across.

The succeeding Selma Breccia was subdivided by Litherland (1970, 1975) into 5 metabreccia units separated by 4 interbreccia units, which have a total thickness of up to $100 \mathrm{~m}$. They are right way up, and dip to the south-east at 33-64 (Figure 27, units 1-5). The lowest metabreccia has a conformable contact with the underlying pebbly metamudstone. The clasts in the three metabreccia beds are angular to rounded in shape, and vary from microscopic in size to over $3 \mathrm{~m}$ across (Figure 28). They range in original composition from homogeneous or laminated slaty mudstone, some with sandy layers, to finely banded siltstone, sandstone, quartzite, and homogeneous pale- to dark-grey limestone. The relative proportions of the different clast types varies upwards in the sequence from $60 \%$ of fine-grained quartzite clasts and 3\% limestone in the lowest metabreccia, to 15\% of fine-grained quartzite clasts and 60\% limestone in the highest metabreccia; the other constituents making up the remaining 25-37\% of the population are relatively constant in amount (Litherland, 1970). Thus the proportion of limestone clasts increases markedly up-sequence as the quartzite clasts diminish in number. Many of the clast types may be matched lithologically with underlying units such as the Selma Black Slates and Selma Quartzite, and the clasts of pale-grey limestone resemble metalimestones from the Appin Group, which crop out on Islay and on the Appin Peninsula. No exotic clasts of igneous or high-grade metamorphic origin have been identified.

The problematical microfossils occur in angular dark-grey limestone clasts (to $60 \mathrm{~cm}$ across) in the topmost metabreccia (B5 of Figure 27), and in the underlying interbreccia unit, IB4, 
exposed inland. Oncolites are seen in hand specimen as rustyweathering spots 1-4 $\mathrm{mm}$ across, and are found in thin section to have a concentric internal structure; their morphology has been described in detail by Litherland (1975). The acccompanying catagraphs are up to $7 \mathrm{~mm}$ across and have a more disordered internal structure. Bryozoan-like fossils were also reported by Litherland. Of particular interest are 0.05-0.2 mm-diameter tubes that penetrate the clasts and, although they are now filled with sparry calcite, could represent burrows formed by parasitic algae (Litherland, 1975).

Bedding in these rocks has a north-easterly strike and the Selma Black Slates have been affected by a series of upright folds with axes plunging gently to either the north-east or the south-west. These folds are associated with the development of a steeply dipping to vertical slaty cleavage that trends north-east, dips to the south-east, and is accompanied by a gently curvilinear beddingcleavage intersection lineation. This cleavage also affects the matrix, together with the more-argillaceous clasts in the selma Breccia. The slaty cleavage in the Selma Black Slates and locally in the metabreccia is cut, and in places strongly overprinted by, a spaced crenulation cleavage, which dips to the north-west at a low angle.

The slaty cleavage is evident in the argillaceous matrix of the metabreccia beds, and the clasts have been tectonically deformed to varying degrees depending upon their lithology. Slaty fragments and mud wisps have been moderately flattened in the cleavage, with quartzite clasts being least deformed, as would be expected. The slaty cleavage is refracted around some of the more-competent boulders and pebbles, and in some cases faint 'strain shadows' are developed. Minor folds and corrugations of the internal bedding laminations are noted in a number of clasts. Where seen on the flat, clean exposures of the metabreccia in the intertidal zone, these folds have axial traces that are parallel to the 055-065 trend of the penetrative cleavage that affects the enclosing matrix (Figure 28), and also to the crude alignment shown by the longest dimensions of the clasts. Contractional deformation has resulted in the formation of internal folds in thosee clasts in which the lithological layering was initially at a high angle to the trace of the slaty cleavage. However, where such bedding laminations were originally at a small angle to, or parallel with, the orientation of the slaty cleavage, the laminations are stretched, disrupted and boudinaged but never folded. These relationships are a demonstration of the fact that the folds preserved in the clasts developed after the breccia was deposited. An analogous situation holds for the folds in the country rock xenoliths enclosed in the Ben Vuirich Granite (see the Ben Vuirich GCR site report in Stephenson et al., 2013b).

A major NE-trending fault cuts the Selma Black Slates and causes a displacement of the metabreccia outcrops (Figure 27).

\subsection{Interpretation}

Minor sedimentary structures show clearly that the Selma Black Slates and Selma Breccia form a single, conformable sequence. 
These units are part of the Easdale Subgroup and are correlated with the Jura Slate Member (see the Kilnaughton Bay GCR site report) and the Scarba Conglomerate Formation (see the Lussa Bay and Kinuachdrach GCR site reports), respectively. There is evidence throughout this succession for increasing instability of the basin margin, as witnessed by the occurrence of slump folds, large isolated clasts and rafts of disorientated sedimentary rock enclosed in mudrock. Coarse-grained, graded beds are found in the Selma Black Slates and breccia units up to $6 \mathrm{~m}$ thick occur in the overlying Selma Breccia.

Early workers identified the Selma Breccia and interpreted it as a 'crush conglomerate' (Flett in Kynaston and Hill, 1908), but subsequent workers are agreed that it is of sedimentary origin (Kilburn et al., 1965). Litherland (1970, 1975) referred to it as a 'sedimentary slide tilloid' but did not discuss the reasons for this interpretation.

The critical evidence for the origin of the Selma Breccia may be summarized as follows:

(i) The underlying sequence shows evidence of soft-sediment deformation and mass-flow deposits, forerunners of the moreextensive and distinctive breccias above.

(ii) The metabreccias form a bedded sequence consisting of 9 separate units, which are laterally continuous. The interbreccia units contain large isolated boulders of original sedimentary rock.

(iii) The first metabreccia unit shows a normal sedimentary contact with the underlying bed, with large boulders at the base preserved in the act of sinking into the underlying mudrock.

(iv) The metabreccia beds consist of a varied assemblage of angular original sedimentary clasts set in an originally muddy to sandy matrix. The clasts appear to have been lithified, and in the case of some of the limestone blocks, bored by organisms, before being transported to their final resting place.

(v) Although there is a random admixture of clast types in all of the metabreccia units, blocks of limestone only appear in the upper beds and are dominant in the top metabreccia unit. Some blocks consist of breccia, suggesting that earlier brecciated material has been reworked in the flows.

(vi) There is evidence of local fracturing and brecciation of clasts in situ.

(vii) All of the clasts are deformed in the S1 slaty cleavage but there is no evidence that the bedding in the source rocks was folded prior to their disruption, and incorporation into, the Selma Breccia.

(viii) There is a lack of cataclastic or mylonitic rocks, or evidence for intense shearing, within or between the metabreccia units.

From the above features it is clear that the deposit originated as a synsedimentary slump deposit, and did not form by the in-situ brecciation, shearing or cataclasis of lithified, bedded strata. Bedding in the clasts was not folded at the time of deposition. Another important conclusion that can be drawn from this study is 
that there is no evidence for either a major stratigraphical or structural break at this level in the Dalradian succession.

Although possible microfossils such as oncolites and catagraphs found in the metabreccias resemble forms that have been reported by Russian workers from the Ediacaran-age strata of Spitzbergen (Litherland, 1975), none of these forms provide reliable evidence for the stratigraphical age of the rocks. However, the tube-like structures that penetrate the oncolites and their binding matrix, were interpreted by Litherland as the burrows of parasitic algae. If this is correct then it indicates that the limestone clasts were lithified and colonized by algae whilst they were accumulating on the basin margin, prior to their transportation into the sedimentary basin by slumping. Litherland (1975) speculated that the source for these exotic limestone clasts might be the CambroOrdovician Durness Group on the North-west foreland of Scotland, but more-recent work (see Rushton et al., 2000) on the age of the Durness Group shows that it is much too young to have provided sediment to the Dalradian basin.

\subsection{Conclusions}

The Selma Breccia, which is magnificently exposed at this site, is a classic example of a rock formed by the large-scale slumping of poorly sorted and very coarse-grained sediment into a marine basin. Sedimentary units formed in this way are not easy to identify with certainty, and their interpretation is commonly controversial. This is especially so where the deposit has been deformed and folded subsequently. The low grade of metamorphism and relatively low strain at Port selma make this an exceptional locality for studying and interpreting such a metasedimentary deposit, and for this reason alone it warrants consideration as a site of national importance.

The metabreccias consist of angular blocks of rock, ranging in size from pebbles to boulders up to $3 \mathrm{~m}$ across, enclosed in what was originally a muddy or sandy matrix. A variety of different rock types are seen in the metabreccia, some of which can be matched in the local, or neighbouring, Dalradian sequences of slightly older age.

Port Selma is also well known for the minute fossil remains, a few millimetres across, which are found in the limestone blocks at the top of the sequence. Unfortunately these fossils are not sufficiently diagnostic to tell us the age of the rock that provided much of the material for the original sedimentary slide breccia, and hence place a maximum age on the metabreccia itself, but they do provide some potential clues as to the likely source area. 


\section{P.W.G. Tanner}

\subsection{Introduction}

This GCR site is located in the wooded valley of the River orchy, $10 \mathrm{~km}$ north-east of Dalmally. It is notable for the wealth of minor structural features that it displays, most of which can be related to the closure of an early major fold, the F2 Beinn Udlaidh syncline. This structure folds the important sedimentary transition between the Grampian Group and the younger Appin Group (Figure 29). The Grampian Group is represented by psammites and semipelites, which can be shown to be overlain stratigraphically by the Beinn Udlaidh Quartzite and the Leven Schists, both of which belong to the lowest part of the Appin Group.

A major feature that makes this section invaluable for teaching and demonstration purposes is that most of the minor structures that can be examined in the field formed during the same phase of deformation, and can be related to a single large F2 fold (Figures 30, 31). The structures are particularly well seen, when water levels are low, on the well-scoured rock surfaces in the banks and bed of this spate river. The best localities are in the vicinity of the dramatic waterfall and rocky gorge at Eas Urchaidh (the 'Falls of Orchy', Figure 29), and along its tributary, the Allt Broileachan. This site is excellent for examining the threedimensional form of plunging minor folds on the metre scale, and for demonstrating their relationship to the cleavages, lineations, and quartz veins found in the different rock types. Minor folds are best seen in relief in the quartzite, and in potholes in the pelite north-north-east of the Iron Bridge at 243 321; they clearly change in vergence northwards as the river section passes from the upper limb of the major fold, through the hinge-zone, to the lower limb. The curvilinear nature of the major syncline axis is revealed by the progressive change in the trend of the minor fold hinges by over $90^{\circ}$ in less than a kilometre (Figure 29).

The general geology of Glen Orchy was established during the primary mapping by the Geological Survey for sheets 45 and 46 (Kynaston and Hill, 1908). However, it was Bailey and Macgregor (1912) who, recognizing the importance of the area, made the first comprehensive structural and stratigraphical interpretation. They recognized that the distribution of the three main rock types is controlled by a flat-lying, isoclinal nappe, the Beinn Udlaidh fold. These workers also found that this fold, which they considered to be as well exposed as any of the small-scale nappes in the European Alps, had been bent around a later upright fold, the Glen Orchy 'Anticline' (now referred to as an 'antiform' or 'dome'). Cummins and Shackleton (1955, figure 7) first identified way-up structures in Glen Orchy, some tens of metres above the waterfall Eas à Chataidh at 248 331, and confirmed the order of succession established by Bailey and Macgregor (1912). Thomas and 
Treagus (1968) studied two areas adjacent to Glen Orchy on Beinn Udlaidh in more detail and published a map of the closure of the Beinn Udlaidh Syncline. The wider area around Beinn Udlaidh, including the crucial section that constitutes the River Orchy GCR site, has recently been the subject of an extremely detailed field and petrographic study of the stratigraphy, structure, metamorphism and minor intrusions by Tanner and Thomas (2010).

The pelitic rocks at this site contain abundant millimetre-sized, partly or wholly chloritized porphyroblasts of garnet, and randomly orientated crystals of biotite, and the entire sequence has been affected by amphibolite-facies regional metamorphism.

\subsection{Description}

\subsubsection{Stratigraphy}

In the River Orchy section at NN 242 318, rocks belonging to the Grampian Group are mainly of finely banded psammite and semipelite, with some pelitic beds a few centimetres thick that contain chloritized garnets. Thin grey quartzite beds, and thin calcareous seams are also present. The latter occur in a distinctive sedimentary association in which the dark brown-weathering calcareous bands, a few centimetres thick, are separated from the pelitic background lithology by a narrow zone of siliceous psammite. These zoned calcareous units generally have an extremely elongated pod-like geometry overall, and die out laterally within a metre or two.

The Beinn Udlaidh Quartzite is commonly coarse grained and feldspathic where it is least deformed, as in the hinge-zone of the major fold at NN 248 332, and locally contains gritty and pebbly layers. It varies from pale grey to white or even pink in colour. Excellent examples of festoon cross-bedding (at NN 248 331), as well as at other localities in the quartzite on the hillside to the north-east of this GCR site, show clearly that the unit is younger than the Grampian Group. Where the boundary between the two units is least affected by later deformation, it is generally transitional over several tens of metres, with interbedding of psammite, semipelite, and quartzite ribs (Thomas and Treagus, 1968, p. 127). The northern contact is not exposed in the River Orchy section, the first exposures north of the quartzite, seen immediately above the waterfall at NN 248 332, being of psammite with thin quartzite beds. At the south end of the section, the entire quartzite unit is thinned tectonically, and the contact can be located to within a metre or so below the dam at NN 242319 , although Thomas and Treagus (1968) considered that the topmost $33 \mathrm{~m}$ of the Grampian Group at this locality constitute a 'passage group'. A dyke and a sill-like apophyse of appinitic rock are intruded close to the stratigraphical base of the quartzite and somewhat obscure its relationship to the psammitic rocks farther downstream.

The overlying Leven Schists have a very uniform lithology and consist of finely banded, dark-grey, schistose biotite-muscovitegarnet-graphite pelites with thin layers of psamite and 
semipelite. The pelites are characterized by a strong beddingparallel schistosity. They contain porphyroblasts of garnet, reaching several millimetres across in places, commonly accompanied by millimetre-sized randomly orientated flakes of biotite. Most of the garnets in the pelitic rocks have been altered to chlorite, fresh garnets being most common in the thin siliceous bands. Significantly, in the exceptionally clean exposures in the area of the gorge above the Iron Bridge, and where the river runs close to the road farther north at NN 243 323, small-scale zoned calcareous units are found, which are identical to those seen in the Grampian Group and are also accompanied by thin beds of steel-grey quartzite.

The boundary between the Leven Schists and the underlying Beinn Udlaidh Quartzite is transitional, as is shown by the presence of thin quartzite beds within the pelite for a distance of a few metres above the main quartzite. This relationship is clearly seen at several places near to the confluence of the River orchy and the Allt Broighleachan (Thomas and Treagus, 1968, p. 127) (Figure 29).

\subsubsection{Structure}

The Beinn Udlaidh Syncline is a sideways-closing and upward-facing syncline whose gently plunging axis changes trend from approximately east-west to north-south as it is traced southwards along the river section. This major change can be monitored by the progressive change in orientation of the hinges of the congruous minor folds (Figure 29, stereoplot b). It consists of an upper limb (with inverted Grampian Group rocks lying above the Appin Group in the south of the area), and a lower limb to the north in which the Leven Schists lie above the Beinn Udlaidh Quartzite (Figure 29). The axial trace of the major hinge-zone passes through afforested ground to the west of the river. The marked curvature of the axial trace, as seen in Figure 29, is due to the intersection of the gently dipping axial surface of the fold with the irregular topography, and is unrelated to the fold axis curvature described above.

When viewed down-plunge to between south and west, the minor folds on the upper limb are seen to have a Z-shaped vergence (Figure 30), which changes first to a neutral vergence in the vicinity of a poorly defined major hinge-zone at about the Iron Bridge, and then to a consistent S-shaped vergence on the lower limb. These minor folds are best seen in the quartzite and the banded Leven Schists, and have wavelengths that vary from tens of centimetres to over a metre (Figure 31). The axial planes of the minor folds, together with the related penetrative cleavage in the pelitic rocks, dip consistently at less than $20^{\circ}$ (Figure 29, stereoplot a). Throughout the section, a stretching lineation, seen sporadically on the bedding or foliation planes, maintains a constant trend of 190-180 and plunges at a gentle angle to either north or south. Evidence that this lineation is a stretching lineation and not a beddingcleavage intersection lineation is seen in the gritty and pebbly quartzite beds in the hinge-zone of the major fold around NN 248 332, where clastic grains are clearly elongated and define a stretching lineation, which lies at right angles to the local 
intersection lineation and to minor fold hinges (Tanner and Thomas, 2010).

Evidence of later ductile deformation superimposed upon the major synclinal structure is restricted to the development of a crenulation cleavage, which is associated with minor folds of $\mathrm{S}-$ vergence in the Grampian Group rocks on the upper limb of the fold, and cross-cuts the earlier $\mathrm{Z}$-folds and penetrative fabric. A weak development of a similar crenulation cleavage and lineation is also seen in the pelitic rocks on the lower limb of the Beinn Udlaidh syncline.

The structural pattern in these rocks is beguilingly simple, and only rarely, even on the cleanest rock surfaces, are isoclinal minor folds of $\mathrm{Fl}$ age seen to be refolded around minor folds congruous to the major syncline (Tanner and Thomas, 2010). Care has to be taken, as some suspected refolded folds have been proved on closer examination, followed by slabbing and sectioning in the laboratory, to be of sedimentary origin In addition, examination of the garnets with a hand-lens reveals that they contain helicitic inclusion trails, which are strongly oblique to an external cleavage, which is axial planar to the F2 minor folds. Thin sections of these rocks show that (i) there is an earlier penetrative cleavage (S1), which pre-dates the formation of the S2 fabric associated with the Beinn Udlaidh Syncline, and (ii) the garnets also grew in the interval between these two deformation events (Tanner and Thomas, 2010).

\subsection{Interpretation}

The field relationships seen at this GCR site, supported by younging evidence from cross-bedding, show that there is a coherent stratigraphical sequence from the upper part of the Grampian Group into the lower part of the Appin Group, with no evidence of a major stratigraphical or structural discordance between the two groups (Tanner and Thomas, 2010). Of particular importance is the recognition of minor sedimentary rhythms, of unusual character, in rocks belonging to both groups. At the contact between the two groups there is evidence of sedimentary interfingering of beds, rather than tectonic interleaving. This observation is in agreement with the relationships seen at the River Leven and Strath Fionan GCR sites. This is an important conclusion as the boundary marks a major lithological change in the sedimentary record, and indeed was formerly taken to be the Moine-Dalradian boundary.

The sedimentary sequence is folded into a major syncline, the Beinn Udlaidh Syncline, which faces up to the east, and has a strongly curved axis. Previous authors have regarded this syncline and the complementary Glen Lochy Anticline as F1 structures (Cummins and Shackleton, 1955; Thomas and Treagus, 1968; Roberts and Treagus, 1975) but Tanner and Thomas (2010) have shown that it post-dates an earlier fabric (see below) and hence can be confidently assigned to the D2 regional deformation. However, only a small amount of deformation, and a gentle warping of the axial surface followed this main deformation event. This suggests that the curvature was a primary feature of the D2 deformation, and not a later effect due to refolding. Analysis of the geometrical 
results from this GCR site, together with those from the adjoining Beinn Udlaidh massif in which the fold is extensively dissected, indicates that this curvilinearity has resulted from the rotation of the original east-west fold axis, as seen in the least deformed rocks, towards the orientation of the north-south stretching lineation (the $\mathrm{x}$-direction of the strain ellipsoid), with increasing deformation (Figure 29, stereoplot b) (Tanner and Thomas, 2010). The upper limb of the fold has been most affected by this increase in strain, and the Beinn Udlaidh Quartzite found there has a platy foliation, lacks sedimentary structures, and is considerably thinner than it is on the lower, less deformed, limb. It also carries a strong stretching lineation.

A petrographical study of the garnet-bearing assemblages shows that the major F2 fold and its associated family of minor folds, cleavage, and lineations, formed after a deformation event which had given rise to a penetrative cleavage and was accompanied by amphibolite-facies metamorphism. Evidence of this early, SI cleavage has been all but destroyed by later recrystallization and mineral growth in the overwhelming majority of rocks, and it is best preserved as a helicitic fabric in the garnet porphyroblasts (Tanner and Thomas, 2010). There is no evidence from this GCR site or from the adjoining area to suggest that either minor or major folding accompanied this early tectonothermal event, and its significance is still being assessed. Tanner and Thomas (2010) concluded that the rocks belonging to the Grampian Group have been affected by the same number and sequence of events as those of the Appin Group, and that there is no evidence for additional deformation phases in the older rocks. These findings support the conclusion that the Grampian-Appin group boundary is not marked by a significant structural break.

\section{4 Conclusions}

The River Orchy GCR site provides an invaluable section through the upper part of the Grampian Group and its continuation upwards into the Appin Group (Lochaber Subgroup). Transitional contacts between the major rock units, coupled with sedimentary repetition of distinctive lithologies, precludes the presence of a major, orogenic, unconformity at this stratigraphical level. This finding is supported by a microscope study of rocks from this GCR site, which has confirmed the field-based conclusion that both groups have been affected by the same number of structural events, having the same intensity of development, and geometry. Thus a boundary that was formerly taken to be the contact between the Moine and Dalradian supergroups can now be confidently recognized as a normal stratigraphical contact between the two lowest groups of the Dalradian succession. This conclusion is supported by observations at the River Leven and Strath Fionan GCR sites.

The rocks at this site are folded over into a large downwardclosing F2 fold, the Beinn Udlaidh Syncline, which lies on its side and has been deeply incised by the River orchy, to reveal its internal geometry. The gorges and rocky bed of the river expose a superlative section which is invaluable as a natural laboratory in which to study the intricate three-dimensional shape of this fold 
and its associated minor structures, and to enable its mode of development and complex history to be further unravelled. One aspect of the work of special interest, is that it is the first locality in the western Grampian Highlands where it can be demonstrated that the so-called 'early' nappe-like folds formed after an even earlier major deformational and metamorphic event.

\section{A9 ROAD CUTTINGS AND RIVER GARRY GORGE (NN $686 \quad 717-\mathrm{NN} 804 \quad 656$ )}

\section{P.R. Thomas}

\subsection{Introduction}

The rock exposures in the $20 \mathrm{~km}$-long section of Glen Garry between the Drumochter Pass and Blair Atholl are of national, if not international, importance since they form an almost continuous section through the Grampian Group rocks in the Central Grampian Highlands. Not only does the bed of the River Garry itself have 75\% exposure, most of it above water level for much of the year, but the parallel A9 road also provides a series of long clean rock cuts. Hence, the exposures are frequently visited by student parties and professional geologists. The GCR site is noteworthy for its wealth of minor folds and sedimentary structures, which can be used to demonstrate the position and geometry of some of the major folds that make up the central part of the Grampian fold belt.

The site lies on the inverted limb of the recumbent, SE-facing Tay Nappe and provides a unique section through D1 and D2 minor and major folds, related to that regionally important structure. It also provides an essential link between two later major upright folds, the Drumochter Dome to the north-west (see Figure 32) and the Ben Lawers Synform to the south-east (see the Ben Lawers GCR site report); those are the folds that control the outcrop pattern of the Dalradian in much of the Central Grampian Highlands, as illustrated and discussed by Treagus (1987, figure 1b and p.12).

The rocks of Glen Garry were originally described by Barrow (1904) as Moine 'granulites' (an obsolete term for high-grade psammitic metasedimentary rocks). The paper mentions 'water-pipe' structures at clunes and some overturned folds, but provides little other specific data. Apart from a brief description of a fold in a quarry on the A9 road by McIntyre (1950), the main work, which forms the basis for this account, is that of Thomas (1965, 1979, 1980, 1988). Further useful comments were made on the sedimentology by Glover and Winchester (1989) and Banks (2007), and on the structure by Lindsay et al (1989).

\subsection{Description}

The following numbered descriptions of key localities start in the north-west, near the summit of Drumochter Pass, and follow the road and river down towards Blair Atholl (Figure 32). All of the exposures are within psammitic rocks of the Grampian Group. The 
dominant fold-set is named $F 2$ and its axial plane schistosity $\mathrm{S} 2$. Rarely observed folds which clearly pre-date F2 or S2 are designated F1, although $\mathrm{S} 1$ is generally parallel to bedding.

\subsubsection{Stalcair Cut (NN 686 717)}

At the third lay-by on the southbound section of the A9 dual carriageway descending from the Drumochter Pass, gently dipping inverted beds face down to the south-east on the $\mathrm{S} 2$ axial-plane schistosity and lenses of calcsilicate rock in the schistose psammites are well seen. Roadside exposures $200 \mathrm{~m}$ to the east, by a pylon buttress, display schistose laminated psammites with superb trough ripple-laminations and larger dune beds as well as sediment slump structures (Banks, 2007; Figure 33). Overturned, NW-vergent, F2 folds in the cut face plunge gently towards $070^{\circ}$ and are clearly downward facing. A strong S2 axial-plane cleavage cuts S1, which is parallel to bedding, and dips at $30^{\circ}$ towards $160^{\circ}$ at this locality. The exposures are on the north-west, inverted, limb of the F2 Garry Synform, the hinge-zone of which is seen at locality 2 .

\subsubsection{Wade Stone Cut. (NN 694 716-NN 699 71) and River Garry (NN 697 714-NN 714 706)}

At the fourth lay-by on the southbound dual carriageway, a high rock face, on the curve of the road, cuts obliquely across the hinge-zone of a major F2 fold, the Garry Synform. The section east of the lay-by is in the gently dipping inverted limb of the synform, with NW-verging minor folds, but east from the retaining wall F2 minor folds become more neutral in vergence as the hinge is reached. The folds, plunging at $20^{\circ}$ to $070^{\circ}$ with an axial-plane dip of $40^{\circ}$ to the south-east, are downward facing. Evidence is based on the many fine examples of ripple-laminated and dune-bedded schistose psammites. Lenses of calcsilicate rock are deformed by S2, but post-D2 microcline porphyroblasts in the schistose psammites could be evidence of later metasomatism.

There are both early quartz veins, which are folded, and later cross-cutting veins. NE-trending microdiorite dykes and faults can also be traced in the rock-face. The major Allt an stalcair faultzone, seen in the Allt Stalcair at NN 693717 to the west, is mineralized with calcite and haematite.

The northbound lay-by, nearer to the River Garry, enables both road and river sections to be seen. Good way-up evidence is found in the river beneath the railway bridge (NN 6995 7131), and immediately upstream is the hinge of the Garry Synform. One kilometre downstream from the railway bridge, the hinge of the major F2 Creag a' Mhadaidh Antiform can be traced (NN 7090 7075), plunging at $10-14^{\circ}$ to $070-080^{\circ}$ with fine examples of overturned folds containing trough cross-laminations on steep limbs and an S2 crenulation schistosity dipping at 20-30 to the south. Exposures around the footbridge at NN 71207065 have considerably tightened and overturned minor folds involving some refolding of F1 folds. These continue downstream to a point where very regular low dips mark the commencement of the 'Dalnacardoch Banded Zone' (see 
locality 3b), about $200 \mathrm{~m}$ upstream from the confluence with the Edendon Water.

\subsection{3a Edendon Cut (NN 7108 7084-NN 7140 7075)}

The next lay-by on the A9 southbound is east of the major F2 closure of the Creag a' Mhadaidh Antiform. At the west end of the rock cut (NN 7114 7083), very tight F1 folds verge north-west and appear to face downwards to the south-east as indicated by deformed current-ripple laminations. At the burn (NN 712 708) a strike-slip fault trending $024^{\circ}$ brings in a more-psammitic lithology and overturned, NW-vergent, F2 folds plunging at $16^{\circ}$ to $075^{\circ}$. At the east end of the lay-by, above a low-dipping ductile thrust, slightly more-open $F 2$ folds plunging at $20^{\circ}$ to $082^{\circ}$ with an axialplane schistosity dipping at $35^{\circ}$ to the south, fold thin quartz veins and are cut by a microdiorite dyke.

\subsection{3b Dalnacardoch Cut (NN 719 705)}

Half a kilometre south-east of the last locality, in the deep southbound road cut, an apparently regular sequence of flaggy to schistose psammites dipping at between $25^{\circ}$ and $30^{\circ}$ is far more complex when closely inspected. This is the "Dalnacardoch Banded Zone', which envelopes very tight F1 and F2 folds as well as a later generation of reclined folds on both major and minor scales. At the north-west end of the highest section (NN 7183 7055), very tightly refolded isoclines occur, whereas farther into the cutting isoclinal folds lie within an apparently simple banding (NN 7198 7046). The cutting also contains bands of mixed gneissose lithologies, in which post-D2 boudins are quite common. Late rotational shears in the form of large kink bands also occur at the eastern end of the cut.

In the River Garry, the Dalnacardoch Banded Zone is at least $4 \mathrm{~km}$ wide from NN 716706 to NN $748 \quad 694$ and contains both F1 and F2 folds, as well as folds of a later deformation. The latter are associated with the north-west limb of the major post-D2 Errochty Synform, which is thought to pass through the River Garry near Dailnafraoich (NN 7375 6983); here, exposures of F1 and F2 isoclines are refolded about reclined folds of the later generation, which plunge at $10-30^{\circ}$ to $140-170^{\circ}$. The river also exposes a number of interesting crush-zones parallel to banding in which angular schistose clasts are preserved in narrow breccia bands less than a metre in thickness.

\subsubsection{Allt Crom Cut (NN 769 690)}

Just to the west of the Allt Crom bridge on the A9 road, a cutting at NN 76886896 exposes the hinge of a major antiformal fold in three dimensions (Figure 34). Plunges of both major and minor folds here are in the range $16-25^{\circ}$ towards $150-170^{\circ}$, but strong axial cleavage planes appear to be restricted to the hinge-zone, where they dip at $40^{\circ}$ to $080^{\circ}$. The western limb dips at $35-45^{\circ}$ towards $080^{\circ}$ and the less-steep eastern limb dips at $20-30^{\circ}$ towards $135^{\circ}$; the interlimb angle from here northwards remains at less than $40^{\circ}$. This 
undoubted major hinge can be traced for $1 \mathrm{~km}$ north in surface exposures and also in the Allt a' Chireachain, $3 \mathrm{~km}$ to the north, at NN 77527194 , where the plunge is $20^{\circ}$ to $140^{\circ}$. In the Garry Gorge immediately to the south, it is difficult to follow the precise trace of the antiform; it is seen towards Glen Errochty, though in a much more-open reclined style at this higher structural level. This fold is equated with the Bohespic Antiform, the major post-D2 fold complementary to the Errochty Synform (see below).

\subsubsection{Black Tank Cut (NN 773 680)}

This wide cutting is dominated by a major, tight, overturned F2 antiform, the hinge of which can be detected opposite the northbound lay-by in schistose psammites dipping at $38^{\circ}$ to $116^{\circ}$. The plunge is unusual for the area at $8^{\circ}$ to $218^{\circ}$ with a cleavage dip of $30^{\circ}$ to $136^{\circ}$. The high rock face is controlled by regularly

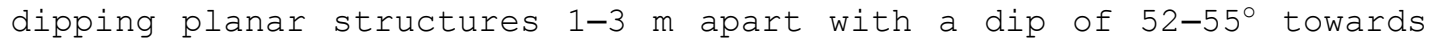
270-290. Some joint faces are mineralized with quartz and pyrite whilst other fault planes display slickensides, some with dip-slip and others involving strike-slip final movements. Several of these discontinuities caused wedge failures of the face during construction. At the south-east end of the cut a large red microdioritic sill, dipping to the east at $26^{\circ}$ in very regular layers of schistose psammite, is downfaulted to the north-west.

\subsubsection{Clunes Gorge (NN 782 671-NN 789 667) and Clunes Cut (NN 785 670-NN 789 668)}

This superb river locality has now been rivalled by the new road cut only $150 \mathrm{~m}$ to the north (Figure 35). Both localities demonstrate the presence of the Clunes Antiform, a major F2 structure, folding cross-bedded and ripple-laminated psammites, quartzites and semipelites, stratigraphically located near the transition between the Bruar Psammite Formation and the Tummel Quartzite and Psammite formations. Linear features seen in the river section, such as the famous 'water-pipe' mullions (NN 784 667) (Barrow et al., 1905, p. 68), plunge consistently parallel to the axes of the $\mathrm{F} 2$ minor folds. Minor folds, abundantly displayed in the road cut (Figure 35), plunge consistently at about $10^{\circ}$ to $045^{\circ}$, with a strong S2 axial-planar cleavage dipping at $20-30^{\circ}$ to $120^{\circ}$. At both localities the SE-vergent, overturned, folds can be seen climbing towards the hinge of the major antiform, which lies near the south-east end of the cut and some distance down the clunes gorge (NN 787 667). The sedimentary structures consistently show that the section is inverted overall and that the F2 folds face downwards to the south-east.

Several vertical and inclined microdiorite dykes cut both the river and the road sections. The widest of these is not only porphyritic but also contains xenoliths made up from a variety of metamorphic rocks, some of which are quite distinct from normal Grampian Group lithologies. Immediately west of one of the dykes, at the north-west end of the road cut, early, presumed F1, isoclinal folds can be seen to be refolded by the F2 minor folds. 
Downstream around NN 790 664, major faults cut the river section and start to bring in lithologies that can be assigned more-readily to the Bruar Psammite Formation.

\subsubsection{Struan Exposures (NN $802 \quad 657-N N 808$ 655)}

Inverted, regularly SE-dipping, flaggy psammites and quartzites form the bed of the River Garry for $1 \mathrm{~km}$ below the junction with the Allt a' Chrombaidh (NN 790 664), but from $200 \mathrm{~m}$ above the twin bridges at Calvine (NN 802 657) and downstream almost as far as Struan church (NN 808 655), numerous overturned F2 folds have been entrenched by the river. These NW-vergent folds have consistent plunges of $20-30^{\circ}$ to $060^{\circ}$, and amplitudes of $5-20 \mathrm{~m}$.

At the 'Salmon Leap' (NN 8037 6565), sedimentary structures are best preserved on the steep limbs of the folds, in laminated schistose psammites with interbedded semipelitic layers. The proof that the layering is true bedding lies in the presence of a number of well-preserved sedimentary dykes, washouts and slump structures (Figure 36), all of which consistently young to the south-east on steep limbs of folds, which thus face down to the south-east as at clunes (locality 6). The rocks here are assigned to the topmost part of the Bruar Psammite Formation.

\subsection{Interpretation}

In essence, the sections at localities 1 and 2 and 4 to 7 are dominated by minor and major folds of the second generation, which fold all earlier planar structures (SO and S1). In the morepelitic lithologies, a strong crenulation cleavage is developed, axial-planar to the folds. Both the folds and the cleavage can be correlated, in style and geometry, with the regional D2 structures. The three-dimensional structure of the area is made more complex by the presence of a third deformation phase, described by Thomas (1980) as D3 but which is thought by others to pre-date the ENEtrending upright folds described as F3 by Treagus (1999, 2000) in the Appin and Argyll group rocks south of the Rannoch-Tummel area. Treagus (2000) gave these late structures a local designation of De, being unable to state categorically whether they pre- or postdate the regional D3 phase.

This late phase is associated with the major N-S-trending Errochty Synform and the Bohespic Antiform, described by Rast (1958) from the boundary of the Grampian Group with the Appin and Argyll groups to the south (see the Meall Dail Chealaich GCR site report). Minor structures associated with this phase become remarkably intense in the mid-part of the Glen Garry section, where the Errochty Synform produces the tight reclined structures at locality 3. This gives rise to the Dalnacardoch Banded Zone, which destroys most of the stratigraphical continuity and causes the re-orientation of all earlier folds around its hinge. Since no sedimentary structures are preserved in this high-strain zone, it is possible that bedding has been transposed and the schistosity might be composite. The presence of well-preserved sedimentary structures outside the banded zone introduces the possibility of some stratigraphical 
subdivision but the psammitic nature of most of the lithologies reduces the confidence of correlations north and west of the Dalnacardoch area.

In spite of the refolding by this later fold-pair, the major F2 folds described above, and the majority of the minor folds on their long limbs, are consistently overturned and vergent to the northwest, whilst being downward facing to the south-east on the second cleavage (Figure 32). The Garry Synform and the complementary Craig a' Mhadaidh Antiform demonstrate this relationship particularly well on the north-west limb of the Errochty Synform. In the core of the Errochty Synform and on its common limb with the Bohespic Antiform, between localities 2 and 4, the facing of the D2 structures is not clear. However, on the south-east limb of the Bohespic Antiform the north-west vergence and south-east facing of the D2 structures is very clear from the exposures of the Clunes Antiform, seen in conjunction with the Meall Reamhar Synform (see the Creag nan Caisean-Meall Reamhar GCR site report). It is likely that the Clunes Antiform is the lateral equivalent of the Creag a' Mhadhaidh Antiform.

The geometry, north-west vergence and south-east facing of the D2 structures is consistent with that observed in the Appin and Argyll groups to the south (see, for example, the Strath Fionan, Slatich and Craig an Chanaich to Frenich Burn GCR site reports). This is consistent with their origin on the lower limb of the Tay Nappe, in its development during top-to-the-SE D2 simple shear of originally upright F1 folds (Treagus, 1987). This concept is supported by the observation, in the clunes locality particularly, that the sedimentary structures are best preserved in the steeply dipping, short limbs of the F2 folds, where they have suffered the least rotation and deformation. The rarely observed minor first generation folds also appear to be facing down to the south-east, on the long limbs of second folds. This suggests that, on the removal of the second deformation, these folds would have been part of an upward-facing fold train (see 1.1 Introduction), originally on the south-east limb of a major F1 anticline.

\subsection{Conclusions}

Glen Garry, from Drumochter to Calvine, is traversed by two parallel, excellently exposed ribbons of rock, one natural (the River Garry) and one man made (the A9 road). Both have been instrumental in providing vital evidence to help our understanding of the complex geological structure of the Grampian Group and without them very little three-dimensional interpretation of the structure would have been possible. Both minor and major folds, as well as sedimentary structures, are clearly and spectacularly displayed in exceptional clean and continuous exposures of rocks that are poorly exposed elsewhere. Most of the folds belong to the regional D2 phase of deformation, are north-west verging and face downwards to the south-east on the inverted lower limb of the F1 Tay Nappe. However, this site also exposes the hinges of an important pair of later folds, the Bohespic Antiform and the Errochty Synform, which exert a major influence on the overall outcrop pattern in the Schiehallion area to the south. 


\section{CREAG NAN CAISEAN-MEALL REAMHAR (NN 771 6017-NN 783 622)}

\section{P.R. Thomas}

\subsection{Introduction}

The two peaks of Meall Reamhar (493 m O.D.; NN 784 618) and Creag nan Caisean (477 m O.D.; NN 778 607) form part of a NNE-trending gentle rocky ridge surrounded by plantations, north of Tummel Bridge (Figure 37). Exposures within the GCR site provide evidence for the downward-facing Meall Reamhar Synform, formerly interpreted as the primary Fl closure of the Atholl Nappe, structurally beneath the Tay Nappe (Thomas, 1979, 1980), but now regarded as one of the major F2 folds that affect the inverted lower limb of the F1 Tay Nappe (Treagus, 2000).

The site also has stratigraphical significance and contains outcrops of two major formations of the Grampian Group, the Bruar Formation and the Tummel Quartzite Formation. On the particularly well-exposed south-east flank of Creag nan Caisean, consistent younging evidence has played a vital role in establishing the stratigraphy on the upper limb of the major fold. This is the type area for the Tummel Quartzite Formation, which here contains a number of distinctive quartzite units separated by laminated schistose psammites. .

\subsection{Description}

The southern boundary of the GCR site coincides with a forestry road, which is accessible either from Easter Bohespic (NN 756 603) in the west or Grenich (NN 804 603) in the east.

The Bruar Formation is exposed on the forestry road to the west of the surge shaft of the Dalcroy Power station (notably at NN 767 603), and on Meall Reamhar. Laminated schistose psammites with way-up evidence are dominant, but there are fewer quartzites and more schistose pelites and semipelites than in the overlying formation. On the summit of Meall Reamhar (NN 784 618) the formation contains more interbedded layers of schistose pelite and is intruded by late-Caledonian NE-trending dykes in the hinge-zone of the Meall Reamhar Synform.

Some $200 \mathrm{~m}$ to the east of the surge shaft, the lowest of the quartzite units at the base of the Tummel Quartzite Formation is well exposed. This is the first of numerous individual 5-30 mthick beds of feldspathic quartzite, which are characteristic of the Tummel Quartzite in this area and extend north-eastwards for 9 $\mathrm{km}$ towards Glen Garry. In general they dip steeply to the southeast. Interbedded with the quartzites are schistose psammites, which display laminations with abundant examples of ripple drift, dunes, convolutions and, more rarely, sedimentary dykes, all younging consistently to the south-east, towards the upper boundary with the Tummel Psammite Formation.

Small-scale minor folds are common, especially within the quartzites. The polyphase nature of the deformation means that 
styles and plunges vary greatly throughout the formation. Two penetrative schistosites are related to two sets of early minor folds, which are commonly difficult to distinguish one from the other. However the dominant vergence of the later of the two sets is to the south-east, and they are associated with an axial planar cleavage dipping steeper than the bedding. Two further sets of crenulation cleavages cross-cut the early sets.

Immediately to the north-west of the summit of Meall Reamhar, the dip of the bedding and the subparallel schistosity become less steep $\left(25-40^{\circ}\right)$ and the second, dominant, penetrative schistosity is steeper $\left(40-60^{\circ}\right)$, indicating that the axial trace of the major Meall Reamhar Synform has been crossed. This is confirmed by the occurrence of inverted cross-bedding in the laminated schistose psammites on the southern slopes of Glen Errochty, to the north of the GCR site. The axial trace of the synform trends north-east below the summit ridge, where there is an antiformal plunge culmination; from here the hinge plunges at low angles to the south-west and north-east.

\subsection{Interpretation}

The excellent exposures in this GCR site provide critical evidence for the key, upward-younging, stratigraphical succession of the Grampian Group from the Bruar Formation through the Tummel Quartzite into the Tummel Psammite above.

The main structural debate concerns the age of the major Meall Reamhar Synform. The presence of small-scale interference structures involving both of the primary deformation phases (D1 and D2), as well as the two later cross-fold phases, indicates the structural complexity of the area, but it is considered that the primary deformation has dominated the large-scale structure. The major closure was initially interpreted by Thomas (1965, 1980) as an F1 closure. Two hundred and fifty metres to the west of the surge shaft at NN 771 601, near the forestry road, there is evidence suggesting that some folding may be earlier than that associated with the Meall Reamhar Synform. Here, very steeply dipping schistose psammites with cross-bedded laminae are cut at right angles by a single (or composite) penetrative schistosity, with no sign of any bedding-parallel schistosity. (Figure 38) This was interpreted by Thomas as being representative of the downward-facing (F1) closure of the major Meall Reamhar Synform. However, it is now thought that this might be an early minor $\mathrm{F} 1$ fold hinge facing south-east, which is not related to the Meall Reamhar closure and certainly does not affect the general upward younging on the steep limb of that fold.

The Meall Reamhar Synform has been recently re-interpreted to be of D2 age, complementary to the Balliemore Antiform and other NWverging major folds within the Appin and Argyll groups to the south (Treagus, 2000). The evidence for this, as well as that in this GCR site, comes from the consistent south-east vergence of F2 minor folds in Grampian Group formations to the south-east (e.g. in the Kynachan Quartzite Formation on Creag Kynachan at NN760 576) and the north-west vergence of the $F 2$ folds to the north-west (as is also described at Clunes-locality 6 of the $A 9$ and River Garry GCR 
site report). These folds are associated with a penetrative S2 schistosity in semipelites, on which the folds face down to the south-east.

\subsection{Conclusions}

The Creag nan Caisean-Meall Reamhar GCR site provides important evidence that helps to establish a succession in the Grampian Group, through its excellent younging evidence and distinctive quartzite lithologies. The Bruar Formation and Tummel Quartzite Formation are both well represented. Creag nan Caisean is one of the best areas in the Central Grampian Highlands to see interference structures in minor fold outcrops, which reflect the regional polyphase fold pattern. The site also provides dramatic evidence, from minor tectonic structures, for the presence of the two limbs of the F2 Meall Reamhar Synform, a downward- and SEfacing anticline that is an important component of the major folds that affect the lower, inverted, limb of the Tay Nappe. This fold is complementary to the Balliemore Antiform described in the Strath Fionan GCR site report.

\section{MEALL DAIL CHEALACH (NN $703 \quad 676-\mathrm{NN} 716$ 675)}

\section{P.R. Thomas}

\subsection{Introduction}

The NW-elongated ridge of Meall Dail-Chealach $(510 \mathrm{~m}$ O.D.) rises above open moorland, $2 \mathrm{~km}$ north of the Errochty Dam. Exposed at this GCR site is one of the best examples to be seen in the Central Grampian Highlands of a late, post-metamorphic, major kink fold, the Trinafour Monoform. This fold refolds the sharp closure of the Errochty Synform and is responsible for its final orientation.

The steep middle limb of the monoform is marked by a narrow line of steep dips that was first recorded by the Geological survey on Sheet 55 (1902) and was described as 'a line of disturbance' in the subsequent memoir (Barrow et al., 1905). It was not however noted by subsequent workers in the area, Anderson (1923), Bailey and McCallien (1937) or Rast (1958). Its significance was realized by Thomas (1965, 1980), who interpreted it as the steep limb of one of a number of major post-metamorphic angular kink folds in this area and named it the Trinafour Monoform (Ft on Figure 39a, following the nomenclature of Treagus, 2000).

\subsection{Description}

Exposures on the ridge of Meall Dail-Chealach from NN 708671 as far north-west as the mid-slopes of Meall Breac (NN 686 697) (Figure 39a) are composed of Grampian Group metasedimentary rocks. The rocks are thinly layered schistose psammites and quartzites containing isoclinal folds of earlier generation structures (D1/D2). These rocks are affected by their proximity to the major 
ductile thrust, the Boundary Slide, which separates them from rocks of the Appin and Argyll groups. All of these rocks are affected by the post-D2 Errochty Synform, which is locally associated with minor folds and a schistosity ( $\mathrm{Fe}$ and $\mathrm{Se}$ on Figure 39a, following the nomenclature of Treagus, 2000). The ridge follows the outcrop of the steep limb of the Ft Trinafour Monoform.

The bedding and subparallel S1 and S2 schistosities on the steep limb of the Trinafour Monoform range in dip from $65^{\circ}$ north-east up to vertical, with a strike of $155^{\circ}$, which is oblique to the main north-west trend of the steep belt. Some of the exposures display minor open folds (Ft on Figure 39a), plunging at 20-30 towards 140$150^{\circ}$ with axial planes dipping gently to the south-west (Figure 39b). Near the base of the crag on the north-east side of the hill, the layering is seen to curve away towards Dubh Lochan (NN 711 674), beyond which the laminated gneissose psammites dip at 30$40^{\circ}$ towards $210^{\circ}$ on the north-eastern gentle limb that marks the north-east margin of the monoformal structure. The south-west closure of the monoform in the Grampian Group rocks is seen $2.5 \mathrm{~km}$ to the north-west (at NN 687 695) and also more clearly in the Appin and Argyll group rocks downstream from the Errochty Dam (at NN 718 653) (Figure 39a). The plunge of the major fold varies from $10^{\circ}$ to $25^{\circ}$ to the south-east and both the amplitude and the wavelength of the fold decrease downwards, so that the fold dies out up plunge on the slopes of Meall Breac (NN 685 698). Down plunge, the monoform broadens to an open structure south-west of Trinafour, where it is accompanied by the open upright Allt Culaibh Antiform and the asymmetrical Croftnagowan Synform to the northeast and south-west respectively (Figure 39).

\subsection{Interpretation}

It is clear that this major line of disturbance refolds all earlier structures, including the Boundary Slide and associated D1 and D2 minor folds and schistosities, and especially the axial trace of the post-D2 Errochty Synform and its associated minor folds and schistosity (the De phase of Treagus, 2000). The Trinafour Monoform is related to distinctive brittle-style minor kink folds with a low plunge to the south-east (Figure 39b). The occurrence of major and minor open and kink folds with gentle south-east plunges is rare in the Central Grampian Highlands, but they appear to be particularly well developed in the flaggy rocks on the gently dipping north-west limb of the Errochty Synform, where they are referred to as the Dt phase by Treagus (2000). The north-east vergence of the Trinafour Monoform is reflected by the minor folds, which also occur in conjugate and oblique sets, exemplified by the Sron Chon folds to the south-west. Late folds of presumably the same generation as the monoform that occur to the west and east (the Allt Sleibh Antiform, Meall na Leitreach Synform and Allt Culaibh Antiform) have progressively steeper axial surfaces with depth (Figure 39b).

The age relationship of the Trinafour Monoform, and the related Ft folds mentioned above, to the other deformation events late in the history of the Grampian orogenic belt is not clear. Their brittle style would suggest that they post-date the ENE-trending folds of 
the D4 phase, such as the Ben Lawers Synform, described in the Ben Lawers GCR site report. The Dt folds must be the consequence of a $\mathrm{NE}$-directed shortening along the length of the orogenic belt. This is in contrast to the supposed transtensional deformation in that direction that is responsible for the NE-trending, late-Silurian, fault set (Treagus et al., 1999) discussed in the Ben Oss GCR site; the age relationship of the Dt folds to these faults is not known.

\subsection{Conclusions}

The Meal Dail Chealach GCR site is of national importance since it is representative of a number of spectacular NW-trending folds, the most impressive of which is the Trinafour Monoform, that formed late in the Caledonian deformation process. In this part of the Central Grampian Highlands these semibrittle-style, monoformal kink folds, which are the latest set of folds that can be identified, appear to be restricted in development to the area between Craiganour Forest and Glen Garry, and have formed in the gently dipping, flaggy, Grampian Group rocks. Around the Errochty Dam area they have also deformed the younger Appin Group rocks above the Boundary slide. The site lies only a few kilometres west of the Trinafour to $A 9$ road and is frequently visited by student parties.

\section{STRATH FIONAN (NN 720 580-NN 745 560)}

\section{J.E. Treagus}

\subsection{Introduction}

This GCR site is located on the slopes of Strath Fionan, immediately adjacent to the minor road which runs around the north side of the isolated mountain, Schiehallion (Figure 41). It provides the only continuous section in the Central Grampian Highlands, from the top of the Grampian Group through the Lochaber and Ballachulish subgroups of the Appin Group (Table 1). Each of the formations has observable sedimentary boundaries with its neighbours and sedimentary structures can be used to establish the continuity and the way up of the succession. Additional attractions include minor folds, a great variety of metamorphic minerals and microdiorite dykes and the area is popular for student field parties and mapping projects.

The uniformly south-dipping sequence was originally interpreted by Bailey and McCallien (1937) as the folded and faulted repetition of the Blair Atholl 'Series' (now the Blair Atholl Subgroup) and of the Schiehallion Quartzite and Killiecrankie Schist, which occur to the south of the GCR site. The junction at the base of the Blair Atholl 'Series' with the 'Moines' (now the Grampian Group) was interpreted as a major synmetamorphic dislocation, since the interpretation required considerable excision of the stratigraphical succession. This tectonic junction, named the Boundary Slide, the equivalent of the Iltay Boundary slide in the 
south-west Grampian Highlands (MacGregor, 1948; Rast, 1963), plays a major role in Dalradian tectonics. This interpretation was supported subsequently by Rast (1958), who interpreted a persistent outcrop of schist immediately above the slide, the Beoil schist, not as a stratigraphical formation but as a product of localized ductile deformation.

The present interpretation is that of Treagus and King (1978) and Treagus (1987) who maintained that the sequence may be directly correlated with the type Appin Group sequence below the Blair Atholl Subgroup and that it is a continuous south-younging sequence, uninterrupted by major folds or dislocations. The zone of Appin Group formations, including the Beoil Schist, immediately above the Grampian Group, although the locus of high strain, was not considered to contain a major dislocation.

The geometry of the dominant set of minor folds, seen in most of the lithologies, shows that the succession lies on the short, overturned limb of a fold (the Balliemore Antiform of Bailey and McCallien, 1937), which is one of the major F2 folds in the region according to Treagus (1987). The stratigraphy and structure of the Strath Fionan area has been described more fully in the Geological Survey memoir for Sheet 55W (Treagus, 2000).

\subsection{Description}

The principal lithologies of the GCR site may be conveniently examined in transects $A-A^{\prime}, B-B^{\prime}$ and $C-C^{\prime}$ (Figure 41).

\subsubsection{Lochaber Subgroup}

Good exposures of the uppermost Grampian Group and of the lowest four formations of the Appin Group can be seen on or close to the line of transect $A-A^{\prime}$ (NN 723 577-721 576). The transect provides the type section for the lowest two formations of the Lochaber Subgroup, the Dunalastair Quartzite and Dunalastair Semipelite.

The Grampian Group psammites (the Kynachan Psammite Formation of the Glen Spean Subgroup) are in sharp contact with the Dunalastair Quartzite and exhibit clear south-younging cross-beds a few metres from the boundary; there is no evidence of unusually high strain or of structural discordance at the contact. The typically rather pink-weathering quartzites and quartzose psammites of the Dunalastair Quartzite, in well-bedded 100-300 mm-thick units, exhibit slight variations in feldspar content, but are rarely as feldspathic as the adjacent Grampian Group psammites. Crossbedding is evident from feldspar and heavy mineral concentrations, and truncated foresets may be observed within a few metres of the Grampian Group, confirming the age relationships.

Good exposures of the Dunalastair Semipelite within the area of Figure 41 can be seen along the ridge crossed by the transect $A-A^{\prime}$, on Speirean Ruadh (NN 735 570) and south-west of Lochan Beoil. Although the dominant lithology in this formation is a biotitemuscovite-garnet semipelite, its characteristic feature is a ribbed appearance on a variety of scales, owing to the presence of psammitic laminae, which are dominant close to the lower boundary. cross-bedding is apparent in the thicker psammites, which are 
similar in character to those of the Grampian Group; no way up has been determined near the line of transect but evidence of the southward younging has been found near Lochan Beoil.

The Beoil Quartzite and Beoil Schist are well exposed to the south-west of the above formations in transect $A-A^{\prime}$, but the type section of these formations occurs to the north of transect $B-B^{\prime}$, on the steep south-facing scarp west of Lochan Beoil. Generally within the area of Figure 41, the Beoil Quartzite can be traced as discontinuous 100-300 mm-thick ribs of pure white quartzite separated by layers of semipelite $10-500 \mathrm{~mm}$ thick. Thin beds (100$300 \mathrm{~mm}$ ) of pelite of Beoil Schist aspect and of quartz-feldspar psammites similar to those in the Dunalastair Semipelite also occur within the formation. The ribs of quartzite are commonly seen to be affected by tight folds with wavelengths of several metres (F1 and F2 of Figure 42, see Interpretation below) and it is clear that this results in considerable duplication. No certain sedimentary structures have been detected in these strongly deformed rocks. The Beoil Schist is well exposed within the area of Figure 41, forming a prominent topographical feature. The schist is characterized by an unusual concentration of muscovite and the presence of pods of vein quartz. The stratigraphically lower half, apart from these characteristics, is very similar to the Dunalastair Semipelite described above. It is a biotite-muscovitegarnet pelite or semipelite with thin ribs of quartzofeldspathic psammite and some quartzite ribs towards the lower, well-exposed, gradational boundary. The upper half has striking muscovite-rich schistosity surfaces studded with 1-8 mm garnets and streaked with quartz veins and pods; it is noticeably less biotitic than the lower part and bedding is not as obvious. No certain sedimentary structures have been detected in these strongly deformed rocks. Boudins of garnetiferous amphibolite are present.

A pronounced topographical hollow separates the Beoil Schist from exposures of the Meall Dubh Striped Pelite and the junction is nowhere well exposed. It is best seen north of the transect B-B' in an area where the stratigraphy is repeated by several F2 isoclinal folds. The type section of the Meall Dubh Striped Pelite Formation is at the northern end of transect $\mathrm{B}^{-\mathrm{B}^{\prime}}$, in a $20 \mathrm{~m}$-long ridge at NN 7386 5661. Here, the delicately striped alternations of fine-grained psammite and schistose muscovite-biotite pelite are well displayed in a 5 m-wide section. Garnet and feldspar porphyroblasts seen here are characteristic of this lithology, as is grading in the 10-30 $\mathrm{mm}$ stripes of fine-grained psammite. Although the junction with the Meall Dubh Limestone is not well displayed, the youngest beds in this section are calcareous; carbonate-rich rocks are seen a few metres to the south, suggesting a transitional boundary. This junction marks the Boundary slide of Bailey and McCallien (1937).

\subsubsection{Ballachulish Subgroup}

The exposures along the line of traverse B-B' (NN 7386 5661-7432 5630) give the opportunity to examine the constituent formations of the Ballachulish Subgroup in reasonable proximity, although some of the type sections detailed below occur elsewhere in Strath Fionan. 
Yellow-weathering, 'grey-hearted' carbonate rock, calcareous schist and tremolitic amphibole schist are all represented in the thin, poorly exposed, Meall Dubh Limestone Formation. Biotite or phlogopite porphyroblasts are usually conspicuous in the latter two lithologies; colourless tremolite and green actinolite occur locally as rosettes. No sedimentary structures have been observed.

The Meall Dubh Graphitic Schist Formation is particularly well displayed on the ridge to the east and west of the line of transect B-B'. The type section is a prominent crag at NN 7409 5645, where the graphitic schist displays $30-100 \mathrm{~mm}$ crystals of kyanite (black, as a result of graphite inclusions) as well as common biotite and garnet and rarer staurolite and feldspar porphyroblasts. Bedding is seen as non-graphitic semipelite ribs at 100-200 mm intervals. Concordant garnetiferous amphibolites are a feature of this formation. The boundary with the Meall Dubh Limestone is not well exposed, although isolated occurrences with admixtures of graphitic schist and calcareous schist show that it is gradational. The upper boundary is seen along strike to the east at NN 7422 5640, on the north side of the ridge of Meall Dubh Quartzite. Here graphitic kyanite-bearing semipelite and pelite merge into a metre of transitional muscovitic, rusty quartzite containing graphitic seams. At the eastern edge of the quartzite outcrop on Meall Dubh (NN 727 567), 2-3 m of a very characteristic transitional facies of the graphitic schist is developed. This consists of finely bedded, fine-grained quartzite with black graphitic laminae, which exhibits cross-lamination in some exposures. Some of the $20 \mathrm{~mm}$-thick semipelitic beds exhibit grading of their graphite content. The younging is consistently towards the overlying quartzite, allowing for the presence of major and minor folds that affect this boundary .

On transect $B-B^{\prime}$ the upper $20 \mathrm{~m}$ of the Meall Dubh Quartzite Formation may be examined on the south bank of the Allt Strath Fionan at NN 7424 5634, where 200-500 mm-thick beds display a characteristic strong pebble lineation and feldspar-rich and heavy mineral laminae. Cross-bedding in $100 \mathrm{~mm}$ beds youngs south towards the Strath Fionan Banded Semipelite, some 20 metres distant. The junction between the two formations is not exposed here, but may be identified farther east on the south bank at NN 7432 5631; exposure is poor but there appears to be no transition. The exposures on Meall Dubh (NN 729 567), where the outcrop is greatly thickened by folding, provide many clean sections where the detailed mineralogy, deformation and sedimentary structures of the formation can be seen.

The Meall Dubh Quartzite typically comprises 70-80\% coarsetextured quartz; the remainder consists of pink and milky-white feldspar occurring as 2-10 mm-long rod-shaped clastic grains, commonly concentrated in thin $(50 \mathrm{~mm})$ beds. Plate-like aggregates of quartz grains (up to $30 \mathrm{~mm}$ in maximum dimension and $5 \mathrm{~mm}$ thick) appear to represent highly deformed original clasts and indicate that the original rock was partly conglomeratic. Cross-bedding on the ridge above the roadside at NN 72755654 and to the east, youngs south towards exposures of the Strath Fionan Banded Semipelite. 
Exposures of the Strath Fionan Banded Semipelite Formation in the

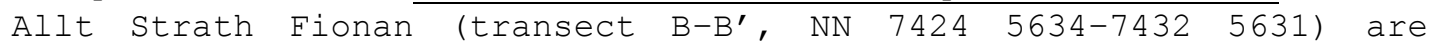
typical of the usual, rather friable, slightly rusty-weathering, muscovitic, interbedded pelite and semipelite in this formation. Four metres of schistose metacarbonate rock mark the transitional junction of the pelite with the succeeding metalimestone in the steep south bank of the burn. These exposures comprise the type section. Typical lithologies can also be seen along the roadside to the west, as far as the junction with quartzite described above at NN 7275 5656. Bedding is usually a prominent feature on a 10$100 \mathrm{~mm}$ scale and broken or cut specimens reveal a wealth of sedimentary structures, in particular channelled cross-laminations and small-scale grading. Sedimentary structures consistently indicate younging to the south. Biotite, but not garnet, is usually evident.

The southern end of transect $B-B^{\prime}$ provides an almost continuous section from the Strath Fionan Banded Semipelite Formation, through the Strath Fionan Pale Limestone Formation into the Tullochroisk Semipelite Formation. However, the quality of the exposure is poor and the latter two formations are better seen at the northern end of transect $\mathrm{C}^{-\mathrm{C}^{\prime}}$. This transect (NN $7137 \quad 5675-7186$ 5658) also permits the examination of all the remaining formations of the Appin Group.

The type section for the Strath Fionan Pale Limestone Formation is at prominent crags south of the road at NN 7275 5638. Although the base of the formation is not seen here, the crags expose $20 \mathrm{~m}$ of white, almost pure, dolomite-tremolite rock. Bedding can usually be detected as 2-3 mm-spaced slightly quartzose laminae; other beds are conspicuously muscovite rich and phlogopite is a minor constituent. The lower beds (to the east) are noticeably more tremolite rich, some exhibiting rosettes $100 \mathrm{~mm}$ across. At the west end of this locality the sharp junction with the overlying Tullochroisk semipelite is seen. Similar rocks occur at the start of transect $\mathrm{C}^{-\mathrm{C}^{\prime}}$ on the north bank of the burn (NN 7237 5675), although here the rocks are more pelitic.

The Tullochroisk Semipelite Formation is well exposed in the burn draining Lochan an Daim, and its sharp lower boundary is well seen in exposures above the type locality of the Pale Limestone at NN 7275 5638. However, the formation is best seen on or near the line of transect $\mathrm{C}^{-\mathrm{C}^{\prime}}$, (Figure 41). A burn section to the south of the transect (NN 7235 5662-7223 5663), where the outcrop is considerably thickened by F2 folding, is the type section of the lower half of the formation. Here the dominant lithology is a rusty-weathering semipelite with psammitic beds, not unlike the Strath Fionan Banded Semipelite, although the Tullochroisk Semipelite contains a greater proportion of fine-grained psammite than the older formation. It is generally a non-graphitic, but pyritic, muscovite-biotite schist, with fine-grained psammite laminae 1-5 mm thick and quartzose psammite ribs 100-200 mm thick. Small-scale cross-laminations and graded bedding have been observed younging south near the boundary with the underlying strath Fionan Pale Limestone.

The upper half of the formation has its type section on the line of transect $\mathrm{C}^{-\mathrm{C}^{\prime}}$, where the upper junction is well seen. 
Lithologies in the upper half of the formation are distinctly moregraphitic than those typical of the lower half, and locally they are as graphitic as the pelites of the overlying Blair Atholl Dark Limestone and Dark Schist Formation. They commonly contain small garnet, staurolite and kyanite crystals, but are characterized by large (c. $5 \mathrm{~mm}$ ) biotite porphyroblasts. Fine-grained psammitic laminations (2-3 mm) and ribs of coarser grained psammite (100-200 $\mathrm{mm})$, with rare small-scale grading, are usually evident. This change of character defining the upper part of the formation is marked by a gully between NN 72265656 and NN 7220 5663, and by a grey metalimestone (maximum thickness $8 \mathrm{~m}$ ) to the east, between NN 72355646 and NN 7278 5636. The junction with the first grey metalimestone of the Blair Atholl Dark Limestone and Dark Schist Formation, marking the start of the Blair Atholl Subgroup, is seen on, and to the north-west of, the line of transect at NN 7186 5660, followed by excellent exposures of the complete Blair Atholl Subgroup (Figure 41). It is also especially well seen to the west and south of Lochan an Daimh (Figure 43).

Immediately to the south of transect $\mathrm{C}-\mathrm{C}^{\prime}$, there is a very clear repetition of the formations of the Blair Atholl Subgroup about a major antiformal core, enclosing the Schiehallion Boulder Bed of the Islay Subgroup. This is the Balliemore Antiform of Bailey and McCallien (1937), a major fold of F2 age according to Treagus (1987). Minor folds, sympathetic to this major closure, verging to the south, plunging to the east and associated with an intensely developed crenulation cleavage, can be observed in most of the lithologies described above.

\subsection{Interpretation}

The sequence exposed in Strath Fionan is a continuous stratigraphical succession from the uppermost formation of the Grampian Group through the Lochaber and Ballachulish subgroups of the Appin Group. The boundaries between formations are usually transitional and sedimentary structures show consistent upward younging; there is no evidence for major repetition by folding nor of dislocation. However, the formations of the lower part of the Appin Group, from the Dunalastair Semipelite through to the Meall Dubh Striped Pelite do show, from the intensity of folding and of schistosity and the absence of sedimentary structures, that these rocks have suffered high strain. This interpretation (Treagus and King, 1978; Treagus, 1987, 2000) contradicts previous interpretations (Bailey and McCallien, 1937; Rast, 1958) that this is a folded sequence of formations now assigned to the Blair Atholl Subgroup and the lower Argyll Group, and that the contact with the Grampian Group is a 'slide'.

The present interpretation is supported by the clear correlation that may be made between this succession, albeit in a very condensed sequence, and the Lochaber and Ballachulish subgroups of the Appin Group in the type area (Figure 2). The latter succession, which contains thicker and more-fully developed correlatives of all of the formations seen in Strath Fionan, is illustrated by the GCR sites in the Loch Leven area (River Leven, Nathrach, Rubha Cladaich, St John's Church, Onich) and Appin area 
(Ardsheal Peninsula and Lismore Island) discussed elsewhere in this paper. Of particular significance in making this correlation is the clear similarity of the Meall Dubh Quartzite with the Appin Quartzite of the type area and, in its pebbly nature, its total dissimilarity with the Schiehallion Quartzite, with which it had been previously correlated.

Two other aspects of this GCR site are important in the context of the interpretation of the Grampian Fold-belt. Firstly, in general the site has an unusual wealth of porphyroblastic metamorphic minerals, including biotite, garnet, staurolite, amphibole, epidote and feldspar. In particular, the spectacular kyanite of the Meall Dubh Graphitic Schist was used in a study by Wells and Richardson (1979) to determine that the Dalradian of the Central Grampian Highlands has been buried to a depth of some $30 \mathrm{~km}$.

Secondly, the wealth of minor structures (folds, cleavages and lineations) in the site has allowed it to be shown that the rocks have undergone four distinct episodes of deformation (Treagus, 1987). The dominant set of minor structures, which can be confidently correlated with the regional D2, show from their consistent southerly vergence that the succession described lies on the northern limb of a major antiform. This is the regional Balliemore Antiform, the axial trace of which lies immediately to the south of the GCR site and is the complementary fold to the Meall Reamhar Synform described in the Creag nan Caisean-Meall Reamhar GCR site report (Treagus, 1987, 2000).

\section{4 Conclusions}

The Strath Fionan GCR site is of national importance in demonstrating the continuity of sedimentation between two of the major groups, the Grampian and the Appin, of the Dalradian supergroup. Of particular importance is the unusual preservation of sedimentary structures in such strongly deformed rocks. The continuity of both the stratigraphical succession and of the structural history across the Grampian-Appin group boundary precludes this junction being interpreted as a major tectonic unconformity. A comparison can be made in this respect with the River Leven and River Orchy GCR sites, where the same conclusion has been reached. Neither is there convincing evidence for the presence of a major low-angled ductile dislocation, the Boundary Slide, which had been suggested by earlier researchers because of the high strain exhibited by units in the lower part of the Appin Group succession.

The site is critical to the reconstruction of the Dalradian sedimentary basin, particularly in the comparison of the very thin succession here with the much thicker equivalent sequences seen in other GCR sites in the Central Grampian Highlands (in the Loch Leven and Appin areas), as well as with those on Islay and on the Garvellach Islands in the South-west Grampian Highlands and with GCR sites in the North-east Grampian Highlands. The site reveals a quite exceptional development of minor-scale structural features which, in conjunction with those of other nearby GCR sites, help to demonstrate the presence of the major structures that make up the Grampian Fold-belt. Minerals that grew during metamorphism are 
also unusually visible to the naked eye in many of the rocks in the GCR site. The geochemical analysis of the mineral kyanite from this site has been of key importance in establishing the great depth of burial that this part of the Grampian Terrane has undergone.

\section{TEMPAR BURN \\ (NN $691 \quad 575-\mathrm{NN} 696 \quad 562$ )}

\section{J.E. Treagus}

\subsection{Introduction}

This GCR site, off the Kinloch Rannoch road on the south side of Strath Tummel, includes part of the Tempar Burn and exposures along an adjacent track that together comprise one of the classic sections through the Schiehallion Boulder Bed Formation (the local equivalent of the Port Askaig Tillite Formation), at the base of the Argyll Group (Table 1). The particular interest of this formation is that it is interpreted as having been deposited from a grounded ice-sheet, which carried material on to a shallow continental shelf. The tillite generally consists of a gritty matrix, in which are scattered clasts of various underlying rock types a few centimetres in length. Most spectacularly, in the upper half, are boulders of pink granite up to $30 \mathrm{~cm}$ across. The site also includes a section through the Schiehallion Quartzite (the equivalent of the Jura Quartzite), which originated as shelf sands above the tillite, and through a metaconglomerate of reworked tillite. The Schiehallion Boulder Bed Formation is possibly the most important 'marker' horizon that has enabled stratigraphical correlation within the Dalradian outcrop from the west of Ireland to Banffshire. It has also been a key horizon in the correlation of the Dalradian with Neoproterozoic successions in Greenland and Scandanavia.

Although this section through the formation was first described by Bailey (1917) and was correlated by him with the Port Askaig 'Conglomerate' of Islay, it was Anderson (1923) who first discussed the arguments for its glacial origin. The formation has also been described by Treagus (2000). Together with the classic localities of the Port Askaig Tillite (see the Caol Isla and Garvellach Isles GCR site reports), the site has attracted wide international interest in the ongoing investigations and debate on the evidence for and implications of Neoproterozoic glaciations.

\subsection{Description}

The Schiehallion Boulder Bed Formation, where most fully developed and exposed as in this section, may be divided into a sequence of lower calcareous metadiamictites with dominantly calcareous clasts and an upper sequence of quartz-rich metadiamictites with a mixture of clast-types, including distinctive pink granitic rocks. The two metadiamictite sequences are generally separated by discontinuous units of quartzite (Figure 44). Exposures and loose material immediately south of East Tempar Farm (at NN 691 575) and along the 
track to NN 696 564, are especially good and accessible, illustrating both calcareous and granitic metadiamictites, as well as the intervening quartzites (Figure 44). Further exposures are seen in the tributary of the Tempar Burn downstream of where it crosses the track at NN 69585628 .

The sequence of the lower calcareous metadiamictites, up to $50 \mathrm{~m}$ thick, is best seen $100 \mathrm{~m}$ east of the sheep dip (NN 6938 5737) and $100 \mathrm{~m}$ east of the track at NN 6954 5705. Exposures of the tremolitic and dolomitic metalimestone that underlies the tillite (the Drumchastle Pale Limestone, equivalent to the Islay Limestone of Islay) can be seen in the grassy hollow some $20 \mathrm{~m}$ to the northeast of these exposures, but the contact is not seen. Individual metadiamictites are separated by beds of schistose calcareous rock free of clasts; bedding is not otherwise observed, except for rare thin (0.5-12 mm) beds of cream-coloured schistose dolomitic metalimestone, and tremolitic psammite.

The matrix of these lower metadiamictites is a schistose calcareous (dolomitic) rock, locally rich in amphibole (radiating blades of white tremolite or pale green actinolite and large hornblende porphyroblasts) and generally rich in a phlogopitic biotite. The matrix, commonly weathering to a rusty-brown, characteristically shows a regular network of depressions, owing to small patches of carbonate minerals, which are possibly small clasts. According to Bailey and McCallien (1937) 'lime-rich' scapolite and diopside occur locally in the matrix. The dominant clasts in the lower metadiamictites are $1-20 \mathrm{~cm}$ diameter, discshaped fragments of schistose dolomitic limestone or limestone, elongate parallel to the schistosity. Although commonly completely weathered out, vestiges of the clasts can be seen at the rims of the holes. Biotite-muscovite semipelite clasts, which are less common, are very elongate and up to $20 \mathrm{~cm}$ in length, and the rarer quartzite and granitic clasts, are up to $25 \mathrm{~cm}$ long but less elongate (ratios of $2: 1$ or $3: 1$ ) and more angular; these clasts become more common upwards.

Two discontinuous units of quartzite, each up to $50 \mathrm{~m}$ thick and occurring at slightly different levels, are seen east of the track around NN 69455709 and NN 6963 5678. These quartzites are not as clean as the Schiehallion Quartzite above, being sugary and feldspathic; they are generally massively bedded and locally they are strongly schistose. Although bedding-plane laminations have been observed, cross-stratification has not been widely detected.

The younger part of the Schiehallion Boulder Bed Formation, up to $70 \mathrm{~m}$ thick, is best seen on both sides of the track above the small burn that crosses at NN 6956 5672); exposure is particularly good around NN 696565 (Figure 45). Clasts of grey or pink granite and microgranite are the most common, followed by pink and white quartzite, biotite-muscovite semipelite, and dolomitic limestone (least common). The pink granite is the 'nordmarkite 'of Bailey and McCallien (1937). Clasts are rarely in contact and spacing appears to be random. Within the clast-rich metadiamictites, the proportion of the rock composed of clasts (greater than $5 \mathrm{~mm}$ in length) varies from 70\% to zero. Some beds, up to several metres thick, are free of obvious clasts (greater than $5 \mathrm{~mm}$ in length) but still have the gritty, feldspathic texture of the metadiamictite 
matrix. The maximum length of clasts, which might be somewhat flattened in the schistosity, is $0.5-30 \mathrm{~cm}$. The more-rare biotitemuscovite semipelite and dolomitic limestone clasts are the smallest, the most strongly deformed (flattened) and consequently appear to be more rounded. The more-common quartzite and microgranite clasts seldom exceed $10 \mathrm{~cm}$, but might display very irregular, angular and non-flattened shapes; the clasts of the granite are typically the largest and display similar variations. Clasts might show pressure-shadow fringes of quartz, carbonate minerals and mica. As with the lower metadiamictites, there is no evidence of sorting by size or composition, although some beds that are several metres thick are clearly free of clasts.

The contact with the Schiehallion Quartzite is not exposed, but evidence elsewhere in the district shows that it is sharp (Treagus, 2000). A thin bed of metadiamictite with reworked granitic clasts is present near the base of the quartzite in the East Tempar track exposures at NN 6953 5631. Clean exposures of the lower part of the Schiehallion Quartzite are exposed in the Tempar Burn downstream of the tributary at NN 6942 5643; scattered clasts of granite and quartzite are present and of particular interest is a 30 m-thick metaconglomerate that is well exposed in the burn at NN 6935 5654. The quartzitic matrix of the metaconglomerate is very similar to the Schiehallion Quartzite itself, but with a somewhat more-gritty appearance. The rock types and sizes of the clasts are much as in the metadiamictites, described above, but they are moreobviously rounded and locally they are in contact with one another. Clasts of grey or pink granite and microgranite are the most common, together with pink and white quartzite, biotite-muscovite semipelite and carbonate rocks.

The metaconglomerates have great potential for both sedimentological and strain studies. Where measured, in the Tempar Burn section, the proportion of clasts to matrix is very variable over a few square metres, from 1\% with isolated single clasts, usually granite, to approximately 70\%, with crowded clasts of a mixture of rock types. The clasts are deformed into disc shapes within the dominant cleavage, which is very close to the bedding; observation of shape is difficult, but most clasts display approximately circular sections. Deformation appears to be more pronounced than in the metadiamictites; measured on surfaces perpendicular to the bedding, granite clast length:width ratios, range between 10.4:1 and 2.1:1, but are commonly about 5:1 and longest dimensions ranged from 2 to $47 \mathrm{~cm}$. Semipelite clast ratios are from 5 to 13:1, and sizes range from 3 to $18 \mathrm{~cm}$.

Downstream, after a further few metres of quartzite, the burn and banks provide excellent exposure of the Tempar Dolomitic Member, the probable equivalent of the Bonahaven Dolomite of Islay.

\subsection{Interpretation}

Subsequent to Bailey's (1917) correlation of the Schiehallion Boulder Bed with the Port Askaig 'Conglomerate', Anderson (1923) discussed the arguments for its glacial origin. He pointed out that the uniform, unbedded nature of the matrix and the haphazard arrangement of the clasts strongly suggest an origin as a till. He 
noted the similarity of the carbonate-rock and the quartzite clasts to the underlying 'Pale Limestone' and 'Banded Group' formations respectively (now the Drumchastle Pale Limestone and Cnoc an Fhithich Banded Semipelite formations of Treagus, 2000), which are exposed to the east of the GCR site. He used this correlation to demonstrate the order of superposition. He further pointed out that the granitic ('nordmarkite') clasts have no likely local source in Britain and must be far travelled. He noted that the base of the Schiehallion Quartite closely approaches the 'Blair Atholl grey limestone' (now the upper calcitic metalimestone of the Blair Atholl Dark Schist and Dark Limestone Formation) in the north of the district, but accepted the possibility that this might be due to either erosion of the sub-quartzite surface, or to later tectonic movements. He noted that the presence of amphibolite clasts suggests a period of igneous activity that pre-dated the diamictites. The present investigation, however, has failed to reveal clasts of true amphibolite, as against green-amphibole (actinolite)-bearing mica-schist.

More-recent discussion concerning the depositional environment of the diamictites in general has concentrated on evidence from the superior exposures of the Garvellach Islands and Islay, e.g. Kilburn et al. (1965), Spencer (1971, 1981, 1985), Eyles and Eyles (1983), Eyles (1988). These authors considered that the diamictites represent a major glacial event of global extent and that they may be correlated with the varanger tillites of Scandanavia and East Greenland (but see Stephenson et al., 2013a for more-recently suggested correlations with other global glacial events). It is generally accepted that the geographically extensive, though discontinuous, distribution of the deposits in the British Isles favours a glacial origin, as opposed to sedimentary slide deposits of a more-local character. The general evidence, throughout their outcrop in the Dalradian, of the mixture of locally derived and exotic clasts, the random distribution and size of the clasts, the lack of bedding within the ill-sorted matrix, the record of dropstone structure and the particular evidence of other glacially-related structures in the South-west Grampian Highlands, makes the glacial origin indisputable.

In the Schiehallion district, the massive nature of the diamictites, their inclusion of stratified, sorted sands, and the subrounded shape of some clasts, supports the interpretation of a marginal glaciomarine environment (Edwards, in Reading, 1986). The local thinning and probable absence of the formation from some areas and the inclusion of clasts of at least two of the preceding formations in the lower diamictites, strongly suggests an unconformable base. The distinctive sedimentary structures attributed to tillites and present in some exposures of the Port Askaig Tillite (see the Caol Isla and Garvellach Isles GCR site reports) have not been observed at this GCR site. Possible dropstone structures have been recorded, but it is difficult to exclude the effect of the strong tectonic deformation. The clasts show no evidence of having been sorted or of having had their distribution controlled by water movement.

There are two beds of metaconglomerate, within the Schiehallion Quartzite, that have clasts of identical lithologies to those in 
the metadiamictites (Anderson, 1923; Treagus, 2000). The significant difference between the metaconglomerates and the metadiamictites is that there appears to be a more strongly bimodal size distribution in the metaconglomerates, such that the intermediate $1-5 \mathrm{~cm}$ sizes are missing; in addition the clasts are less dispersed, although rarely in contact, and they are significantly more rounded. This supports the interpretation of Anderson (1923) that these rocks represent reworked diamictite material derived by fluviatile or marine erosion.

\subsection{Conclusions}

The Tempar Burn GCR site is of international importance for its clear exposures of a Neoproterozoic glacial deposit. The "boulder beds' (metadiamictites) that make up the Schiehallion Boulder Bed Formation are composed of blocks and pebbles up to almost a metre across, sitting isolated in a matrix that was originally sand and silt. The blocks and pebbles can only have been dropped from floating ice. They include a wide range of rock types, including some derived locally from underlying formations, but particularly significant, are the commonly occurring 'stones' of a type of granite that does not crop out in Britain and therefore might have been carried a great distance across an ocean. The GCR site is thus of great importance for the light it sheds upon climate and sedimentary processes in the late Precambrian, but it is also celebrated for its significance in the correlation of Dalradian formations across the British Isles, as well as with possibly equivalent deposits in Greenland and Scandinavia. Studies of the deformed shapes of the 'stones' are important for estimating the strains that the Dalradian rocks were subjected to during the Caledonian Orogeny.

\section{ALLT DRUIDHE (NN 6422 5723-NN 6423 5662)}

\section{J.E. Treagus}

\subsection{Introduction}

The lower part of the Allt Druidhe, which drains into Loch Rannoch $3 \mathrm{~km}$ south-west of Kinloch Rannoch, has been selected as offering the best section across the Boundary slide, the most important synmetamorphic high-strain zone and dislocation to affect the Dalradian rocks of Scotland. The Boundary slide is known to extend for at least $90 \mathrm{~km}$ from the Dalmally district (see the Ben Oss GCR site report) to the Schiehallion district, although demonstrable dislocation and excision of strata decrease towards the north-east (see the Strath Fionan GCR site report). If proposed correlations with similar structures are correct (e.g. the Benderloch and Ballachulish slides; see the Camas Nathais and St John's Church GCR site reports; Roberts and Treagus, 1977c) the dislocation can probably be traced for most of the length of the Scottish Dalradian outcrop from the Appin district in the south-west to the North-east 
Grampian Highlands (see the Bridge of Brown GCR site report in Stephenson et al., 2013b).

In its outcrop between Dalmally and Loch Errochty $(9 \mathrm{~km}$ north-east of this GCR site), the slide marks a hiatus in the Dalradian stratigraphical succession (Table 1), juxtaposing Grampian Group psammites below, against quartzites, semipelites and pelites of the Argyll Group above. It is only in the area south and east of Loch Errochty that members of the missing Appin Group gradually appear between the other two groups, until the complete succession is restored locally in strath Fionan (Roberts and Treagus, 1977c; Treagus, 1987, 2000).

The slide was first recognized in the Schiehallion area, to the north-east of this GCR site, by Anderson (1923) and its outcrop was mapped throughout the district by Bailey and McCallien (1937). Its origin was discussed further by Rast (1958) and Treagus (1987, 2000). The present account is based on the mapping and descriptions of P.A.R. Nell (BGS 1:10 000 Sheet NN65NW, and in Treagus, 2000).

\subsection{Description}

The description below is taken principally from the almost continuous exposures in the Allt Druidhe (NN 64195731 to 6420 5604), complemented by information from the hillside on its two sides, especially that towards Meall Druidhe to the west.

From NN 64195731 to NN 6421 5713, the course of the burn is controlled by a steep NNW-trending fault with SE-dipping Grampian Group psammites exposed on its two sides (Figure 46). Bedding on a 1 to $30 \mathrm{~cm}$ scale is evident; cross-sets are also seen, but way-up has not been determined. At NN 6421 5713, south of a prominent microdiorite dyke, the psammites become more schistose and flaggy and are seen for a further $100 \mathrm{~m}$ as far as NN 6421 5704, where the fault crosses the bed of the burn. The psammites are succeeded, as far as NN 6423 5690, by a sequence of pink and white quartzites, interbedded with platy psammites and semipelites containing a highly muscovitic pelite; several concordant sheets of microdiorite cut these beds. In the lower part of this sequence, the lowest pink, feldspathic quartzite can be correlated clearly with the Dunalastair Quartzite, the lowest formation of the Lochaber Subgroup, and the highly muscovitic pelite is correlated with the Beoil Schist. Striped biotite-muscovite psammites and semipelites below and above the Beoil schist must represent the Dunalastair Semipelite and Meall Dubh Striped Pelite formations respectively, both of the Lochaber Subgroup. Above these units, a few centimetres of graphitic kyanite schist, an upper 15 m-thick unit of pebbly quartzite and a 50 m-thick unit of banded semipelite and pelite can be equated with the Meall Dubh Graphitic Schist, the Meall Dubh Quartzite and the Strath Fionan Banded Semipelite formations, respectively, of the Ballachulish Subgroup as seen in the Strath Fionan GCR site. The Meall Dubh Limestone Formation is not represented.

At NN 6421 5704, the Strath Fionan Banded Semipelite Formation (Ballachulish Subgroup) is in contact with strongly deformed and boudinaged strata that can be assigned to the Easdale Subgroup of 
the Argyll Group, thereby marking a major dislocation and excision of strata. Some $40 \mathrm{~m}$ of strongly deformed, schistose, rustycoloured, feldspathic quartzite with thin interbeds of amphibolite (equivalent to the Carn Mairg Quartzite), followed by a few metres of graphitic schist (equivalent to the Ben Eagach Schist) are followed by a major sequence of calcareous schist, calcareous quartzites and interbedded amphibolites. The latter sequence can be traced laterally, to the north and south into outcrops of certain Ben Lawers Schist Formation (see, for example, the Slatich GCR site report). Above the Ben Lawers Schist outcrop, at NN 6421 5638, are $10 \mathrm{~m}$ of graphitic schist (better seen on the hillside to the north-east) followed by a major unit of schistose pebbly quartzite, a repetition of the Ben Eagach Schist and Carn Mairg Quartzite formations.

From the uppermost psammites of the Grampian Group southwards, throughout the section, a 30-40 SE-dipping, penetrative schistosity, is parallel to bedding where the latter is visible. The schistosity planes in the amphibolites and the pebbly quartzites exhibit a strong lineation of hornblende and of the pebbles, generally pitching at a high angle (over 50\%) to the southwest. Amphibolite boudins, intersection lineations and rare isoclinal fold hinges pitch with the same general reclined attitude.

The Lochaber Subgroup formations in particular are cut by faultplanes, usually associated with brecciation, dipping at lower angles to the south-east than the schistosity and pre-dating the microdiorite sheets.

\subsection{Interpretation}

The Boundary Slide occurs here on the short common limb of the regional Meall Reamhar Synform-Balliemore Antiform F2 fold-pair, the latter being represented at the GCR site by the repetition of the Ben Eagach Schist and Carn Mairg Quartzite about the Ben Lawers Schist in the fold core. The penetrative schistosity at the site (the regional $\mathrm{S} 2$ ) is essentially parallel to bedding but can be demonstrated to be axial planar to the fold-pair elsewhere (e.g. in the Strath Fionan GCR site).

No measurement of the scale of displacement on the slide is possible, nor have directional movement indicators been identified. The apparent parallelism of the intersection lineations, the foldhinges and the extension direction is attributed to the high strains in the slide-zone. The locally strong pebble and hornblende stretching lineations, pitching steeply to the southwest on the S2 schistosity planes, give an indication of the intensity of the strain, as do the common boudinage axes pitching in the same direction. These features together suggest strong flattening strains in the slide-zone with a finite extension direction pitching steeply to the south-west on the schistosity.

Some of the telescoping of the stratigraphical succession of the Appin Group at the GCR site is considered to be the result of small movements (metre-scale) on the low-angle sE-dipping faults, which cut down section. Evidence in similar sections to that seen at the GCR site, between Loch Rannoch and Loch Errochty, suggest that such 
thrusts are numerous in the slide-zone and are commonly occupied by the later, slightly discordant, microdiorite sheets.

There can be little doubt concerning the stratigraphical assignations given above for the formations of the Appin Group, as the formations can be traced north-eastwards into the type formations of the Loch Errochty and Strath Fionan areas (Treagus, 2000). Similarly, the formations belonging to the Argyll Group can be traced southwards into type areas in Glen Lyon. Thus it is clear that a major hiatus exists between the Strath Fionan Banded Semipelite and the Carn Mairg Quartzite formations, in this highly strained sequence. The missing formations include the metalimestones and graphitic semipelites of the upper Appin Group, together with the Schiehallion Boulder Bed, the Schiehallion Quartzite and Killiecrankie Schist of the Argyll Group, certainly representing several hundred metres thickness of the type stratigraphical succession seen in the Strath Fionan GCR site and to the south of Schiehallion. In addition to this major hiatus, it is considered that the whole section from the top of the Grampian Group into at least the lower part of the Ben Lawers Schist represents a zone of high strain, in which there are probably many planes of discrete movement.

From consideration of evidence along the Boundary Slide-zone elsewhere in the Schiehallion area (Treagus, 1987, 2000), it is clear that the stratigraphical hiatus can be explained, at least in part as a result of top-to-the-NW thrust-like movements during the regional D2 deformation. However, this does not exclude the possibility of movements contemporary with the D1 deformation, which have been identified elsewhere in the Schiehallion area.

It is not clear to what extent any, or indeed all, of the hiatus can be attributed to sedimentological causes. Treagus (2000) provided evidence, from elsewhere in the Schiehallion district, that some substantial thinning of parts of the succession is an original sedimentary variation and suggested that such parts were preferentially thinned tectonically. Soper and Anderton (1984) have suggested that movements on some Dalradian slides might have originated as low-angle normal faults during sedimentation, and Anderson (1923) most-perceptively considered the possibility that the hiatus could represent an original normal fault, later subjected to intense shear. Both Anderson (1923) and Bailey and McCallien (1937) considered, but rejected, the idea that the slide might have originated as an unconformity and essentially favoured the explanation of a synmetamorphic dislocation, as presented here. Further research at this GCR site could well help to resolve these matters.

\subsection{Conclusions}

The Allt Druidhe GCR site provides a rare opportunity to observe the zone of rocks that contains the Boundary Slide, a high-strain zone critically important in the development of the structure of the Dalradian and contemporary with folding and metamorphism. It can be demonstrated within this GCR site that there is a major gap here in the normal stratigraphical succession, with several hundreds of metres of rocks missing. It is likely that there are 
many discrete dislocations within a zone of strongly deformed rocks. The evidence for this high strain is in the unusual nature of the small-scale structures seen in the section. It is considered possible that some of the movements on the slide might be associated with early faulting and changes of thickness during the deposition of the sediments, a hypothesis that could be tested by further work in the area of this GCR site.

\section{SLATICH (NN $632 \quad 477-$ NN $641 \quad 486$ )}

\section{J.E. Treagus}

\subsection{Introduction}

The Slatich GCR site, on the low slopes of middle Glen Lyon, provides exceptional exposures across the hinge-zone of a major F2 antiform. It also exhibits minor structures of both the preceding D1 phase and the succeeding D3 phase. These exposures also give a rare, accessible section across three formations of the Argyll Group, from the calcareous schists of the Ben Lawers Schist Formation up through the Farragon Volcanic Formation into the kyanite-garnet schists of the Ben Lui Schist Formation (Table 1).

The major F2 fold, the Ruskich Antiform, is the correlative of the Ben Lui Fold of the South-west Grampian Highlands, one of the major structures of the Grampian fold-belt. This correlation was first made by Bailey and McCallien (1937) and observations of the minor structures and development of the major structural context have been made by Nell (1984) and by Treagus (1987, 1999).

\subsection{Description}

The Ruskich Antiform in the area of the GCR site is represented by the zig-zag outcrop pattern of three formations of the Argyll Group, which define its hinge-zone (Figure 47).

The Ben Lui Schist can be characterized generally as a semipelitic garnet-quartz-mica schist, alternating with pelites and psammites on scales from centimetres to several metres. The formation is typically garnetiferous but, unusually for the area, also contains local kyanite, best seen in crags around NN 635480 , north of Slatich. The Farragon Volcanic Formation is well exposed in the crags above and east of Slatich around NN 640 477, where it comprises a delicately striped, centimetre-scale, alternation of amphibolite and quartzite. A good section of the Ben Lawers Schist is seen above Roromore, where virtually the whole formation may be examined in a small burn from NN 63854686 to NN 6404 4642; it is typically a chloritic calcareous schist with a hundred metres or so of dolomitic quartzite at its base, and with concordant amphibolites above. This section allows the junctions with the Farragon Formation below and the Ben Eagach Schist above to be seen.

The principal interest of the site is in the closure of the Farragon Volcanic Formation around the Ben Lui Schist in the core 
of the Ruskich Antiform (NN 640 487). In the south of Figure 47, around NN 638 468, the regional dip of this boundary is $40^{\circ}$ to the south-east; farther north, the same boundary on the opposite limb, around NN 634 484, has a regional dip of $60^{\circ}$ to the south; the major hinge plunges almost due east at $30^{\circ}$. Minor structures (minor folds and bedding/schistosity relationships) with opposed vergence on the two limbs, sympathetic to the major antiform, can be seen at these two localities.

The limb south-east of the hinge is considerably corrugated by coaxial intermediate-scale folds (tens of metres limb length), which are well exposed on the hillside north-east of Slatich, around NN 640 477. Some of these folds are sympathetic to the major antiform but other intermediate-scale folds, with upright axial planes and a crenulation cleavage, are superimposed. This locality therefore offers the opportunity to examine three generations of minor foldsF1, F2 and F4 of the regional phases. Not only are minor, metrescale, structures of the latest generation (F4) superimposed on the dominant phase of minor folds (F2) (all plunging east), but also rare refolded minor isoclinal folds of the earliest generation (F1) are developed in the finely-bedded quartzites and amphibolites of the Farragon Volcanic Formation (Figure 48).

\subsection{Interpretation}

The Ruskich Fold was first recognized by Bailey and McCallien (1937) in their perceptive paper on the Schiehallion-Glen Lyon district. They interpreted the fold as a major primary nappe closure below that of the 'Iltay Nappe' (now the Tay Nappe) and thus equivalent to the Ben Lui Fold of the Dalmally district in the South-west Grampian Highlands (Bailey, 1922). However, the fold has been re-interpreted from a subsequent investigation of the associated minor structures by Nell (1984) and Treagus (1987) as a major F2 fold. The dominant penetrative schistosity is axial planar to the abundant minor folds which are sympathetic in vergence to the major fold. This schistosity is associated with the growth of garnet and can be correlated with the S2 fabric, which dominates the pelitic rocks of the South-west and Central Grampian Highlands. Only rare examples of Fl minor folds are seen, such as the isoclinal folds in the finely banded amphibolites of the Farragon Formation, which are clearly refolded by $F 2$ minor folds (Figure 48).

It has been confirmed that the Ruskich Fold has a similar geometry and position in the structural pile to the Ben Lui Fold, which has also now been established as a D2 structure by Roberts and Treagus (1975). Although separated by several major, cross-strike faults (Treagus, 1991) the axial traces of the Ruskich and Ben Lui folds have been correlated on the ground (Roberts and Treagus, 1979). The Ruskich Fold can be shown to have been superimposed on major F1 folds related to the early, Fl Tay Nappe, which can be identified in Glen Lyon to the north of this GCR site (Nell, 1984; Treagus, 1987). The fold is seen as a major component of the zone of D2 complication in the Schiehallion area, which marks the northern limit of the dominantly inverted rocks of the Flat Belt to the south. 
A further feature of this GCR site, not seen in the Ben Lui area, is the superimposition on the Ruskich Fold of a later fold-set, both intermediate and small scale, with an associated crenulation cleavage. These structures belong to the regional F4 set, related to the major Ben Lawers Fold to the south (Treagus, 1964b) (see the Ben Lawers GCR site report).

\subsection{Conclusions}

The Slatich GCR site provides a rare example of almost continuous exposure across the hinge-zone of a major fold, the Ruskich Antiform. The fold hinge can be traced from the detailed mapping of three of the principal formations of the Argyll Group in easily accessible exposures on either side of Glen Lyon. Observations of small-scale folds and cleavages have revealed that the major fold belongs to the second (D2) phase of the four important episodes of deformation that affect the Dalradian rocks. Unusually, smallscale folds of the first generation (F1) can also be identified, clearly pre-dating those of the second generation. The secondgeneration folds themselves have small-scale structures of a still later generation (the regional F4 phase) superimposed upon them. Thus the small-scale structures can be used not only to establish the sequence of deformation events but also to identify the relative age of a major fold. The Ruskich Antiform is equated with the Ben Lui Fold of the Dalmally area (see the Ben OsS GCR site report), and can be followed for several tens of kilometres across the Central Grampian Highlands. It is one of the most significant structures involved in the building of the Grampian Fold Belt.

\section{BEN LAWERS} (NN $621 \quad 368-$ NN 595 415)

\section{J.E. Treagus}

\subsection{Introduction}

This GCR site, on the western and southern flanks of the Ben Lawers mountain range, illustrates typical structures within the inverted limb of the Tay Nappe, the major fold that dominates the structure of the south-eastern Grampian Terrane. It also contains the type locality of one of the major post-nappe folds, the F4 Ben Lawers Synform. In addition to the structure, the exposures described within this very large GCR site, have been selected to illustrate the stratigraphy of the four highest formations of the Argyll Group in the Central Grampian Highlands.

The regional inversion of the succession on the lower limb of a major fold has long been established (the Iltay Nappe of Bailey, 1922 or the Tay Nappe of Shackleton, 1958). The details of the local structure, particularly that of the Ben Lawers Synform, have been studied by Elles (1926), Elles and Tilley (1930), Treagus (1964b) and Nell (1984). The site, which belongs to the National Trust for scotland and is famous for its plants and wildlife, has a 
visitor centre that is much visited by the general public who would benefit from the availability of more geological information.

\subsection{Description}

The localities are described from south to north, up the southern slopes of Ben Lawers which, as the succession is inverted, means that the descriptions progress approximately from the youngest to the oldest formations (Figure 49). Three phases of deformation can be discerned in these rocks, designated D1, D2 and D4 in the descriptions below; the attribution to these regional phases is justified in the subsequent 'Interpretation'.

The youngest formation represented, the Loch Tay Limestone of the Tayvallich Subgroup, is seen in the small quarry at NN 62123678 (Figure 49, locality 1). The dip of the beds (some $30^{\circ}$ to the north-west) in the semipelite laminae in the limestone is typical of the regional dip on the south limb of the F4 Ben Lawers Synform. A gently $\mathrm{NE}-$ plunging lineation (e.g. $10^{\circ}$ to $025^{\circ}$ ) results from the intersection of bedding and a nearly bedding-parallel schistosity (S2), dipping less steeply to the north-west, and from the hinges of rare NW-verging isoclinal F2 folds. Pelites within the limestone show a steep NW-dipping 54 crenulation cleavage.

A well-exposed section from the next oldest formation, the Ben Lui Schist of the Crinan Subgroup, through the Farragon Volcanic Formation and into the Ben Lawers Schist of the Easdale Subgroup, is seen in the Burn of Edramucky from NN 61843725 to NN 61253910 (locality 2). In the Ben Lui Schist, below and above the road at NN 6145 3756, the quartz-rich, garnetiferous, locally graphitic, interbedded semipelites and pelites show structural features similiar to those described above for the Loch Tay Limestone. NWverging folds are well developed, with a penetrative axial-planar S2 schistosity and with plunges at low angles varying in trend from 050-020. Going up the burn section, the north-north-west dip of the bedding gradually increases to about $50^{\circ}$ at the Farragon Volcanic Formation junction (NN 6125 3910), and the F2 folds are more-constantly ESE-trending, with a northerly vergence. The latter formation, comprising finely interbedded semipelites and amphibolites, is exposed in the river gorge and is transitional northwards into the quartzites and calcareous schists of the Ben Lawers Schist. The Farragon Formation here contains small, NWverging, tight $\mathrm{F} 2$ folds which refold earlier $\mathrm{F} 1$ isoclines.

The Ben Lawers Schist is not well exposed in the burn and the rocks at this structural level are better seen in the road section at NN 601390 (locality 3), described in detail by Treagus (1964b). Here, upright metre-scale folds, associated with a well-developed ENE-trending S4 crenulation cleavage, are seen to refold northverging, tight F2 folds, related to a subpenetrative schistosity (Figure 50). The earlier folds, which here trend between westnorth-west and north-west, themselves fold an earlier S1 schistosity and a mineral (quartz-chlorite) lineation with a more north-north-westerly trend. Fl isoclines with a north-west to west trend and northerly vergence are seen rarely and appear to be associated with the earliest schistosity and mineral lineation. The upright F4 folds have an enveloping surface that defines a 
gentle northerly dip of the major fold limb, near to the axial zone of the Ben Lawers Synform. Farther north, near the road on the east side of Lochan nan Lairige at about NN 600 406, and on the hillside above, the same generation of $F 4$ folds are seen to have a neutral vergence in the hinge-zone of the Ben Lawers Synform. The hinge-zone is very well seen looking across the lochan to the cliff section on its west side in which the bedding and the upright $\mathrm{S} 4$ cleavage are apparent on a grand scale.

The Ben Lawers Schist is not well seen on the north limb of the Ben Lawers Synform but at the tunnel portal at the north end of the lochan (NN 5953 4115; locality 4), the Farragon Volcanic Formation is exposed, with bedding here dipping at a low angle to the south. Many loose specimens provide examples of tight F2 folds that rarely show refolded $F 1$ isoclines, subparallel to a strong hornblende lineation.

Within the Ben Lawers Schist on the north limb of the Ben Lawers Synform, there is an isoclinal infold of schistose graphitic pelite, assigned to the Ben Eagach Schist Formation; this is exposed on the north flank of Meall Corranaich. In the core of the fold, the graphitic pelites are transitional into schistose pebbly quartzites of the Carn Mairg Quartzite Formation. The two limbs of this fold, both dipping at moderate angles to the south-east, are exposed in a burn between NN $624 \quad 433$ and NN 633428 and in two burns to the south-west (NN 624 426, north limb and NN 625416 , south limb) (locality 5). In these exposures, the plunge of the tight F2 fold-set is at moderate angles $\left(10-40^{\circ}\right)$ to the east-southeast, with vergence both of the folds and of the axial-planar schistosity/bedding intersection consistently to the north; these folds are overprinted by the upright S4 crenulation cleavage. The infold must of D1 age, pre-dating the D2 and D4 deformation phases.

\subsection{Interpretation}

The exposures described in this GCR site have long been acknowledged to lie on the inverted limb of the Tay Nappe, where they are affected by the later Ben Lawers Synform (e.g. Elles and Tilley, 1930; Treagus, 1964b). The dominant north- to NW-verging folds with the penetrative to subpenetrative axial-planar schistosity are of the regional F2 generation, which is considered to be the main phase associated with the generation of the Tay Nappe (Harris et al., 1976). The axial trend of the F2 minor folds and of the SO/S2 intersections, which is N-S in the Flat Belt south of the site, curves progressively through the area of the site from north-north-east in the south through north-east to east and then east-south-east in the north. Further research in the Ben Lawers area might contribute to the understanding of this phenomenon and of the evolution of the Tay Nappe.

The regional D1 phase is represented by the earlier fabric that can be seen to be crenulated by the S2 cleavage planes, and by the small-scale isoclines and mineral lineation in the Ben Lawers Schist and the Farragon Formation. Data are too sparse to state a trend or vergence for these structures, though the mineral lineation appears to have a north-north-west trend, both in the Farragon Formation and in the Ben Lawers Schist, similar to that 
widely reported elsewhere in the flat Belt. The major infold of the Ben Eagach Schist and Carn Mairg Quartzite in the Meall Corranaich exposures is overprinted by the D2 structures and thus must also be of D1 age; from its outcrop pattern it has a northeast trend and thus must have been (at the time of D2) an anticline facing south-east. According to Treagus (1987, 2000) these major Fl folds originally faced steeply upwards.

The major fold that affects bedding and 52 within the area of the GCR site is the regionally important F4 Ben Lawers Synform, a gentle deflection of the originally subhorizontal limb of the Tay Nappe. The fold is associated, in all lithologies but particularly within the Ben Lawers Schist, with upright intermediate- and smallscale folds trending east-south-east and their axial-planar crenulation cleavage. The vergence relations of the small-scale folds and of the cleavage across the major fold are particularly clear.

\subsection{Conclusions}

The Ben Lawers GCR site provides exceptional sections through four of the main formations of the Argyll Group and is of national importance in providing remarkably clear evidence of the total inversion of the sequence in this part of the Central Grampian Highlands, on the lower limb of a major early fold, the Tay Nappe. These upside-down rocks constitute the Flat Belt, which extends south-east across strike for $25 \mathrm{~km}$ to the Highland Border and for some $250 \mathrm{~km}$ laterally along strike, and dominates the structure of the south-eastern Grampian Terrane. Two generations of minor structures, folds and cleavage planes, related to the D1 and D2 movements that produced the nappe are well displayed.

Within the area of the GCR site another major fold that later folded the inverted rocks, is totally displayed, together with associated minor structures. This F4 fold, the Ben Lawers Synform, is one of the most important late folds in the overall Dalradian structure.

\section{CRAIG AN CHANAICH TO FRENICH BURN (NN $811 \quad 546-\mathrm{NN} 818 \quad 545$ )}

\section{J.E. Treagus}

\subsection{Introduction}

The Craig an Chanaich to Frenich Burn GCR site incorporates the principal exposures of a body of stratiform baryte that is unique in the British Isles and in Europe. As well as the unusually pure, bedded baryte, the body also contains rare barium silicate minerals and stratiform sulphides. It has a maximum thickness of $80 \mathrm{~m}$ and extends for $7 \mathrm{~km}$ to the east of the GCR site along the Meall Tairneachan-Farragon Hill ridge between Strath Tummel and Strath Tay. The baryte occurs within the Ben Eagach Schist Formation of the Easdale Subgroup; it is involved in all three of the regional phases of deformation and the regional metamorphism. 
The mineralization was first discovered by the Geological Survey in 1975 during stream-sediment sampling and was described by coats et al. $(1978,1981)$. It was the subject of a PhD. thesis by Moles (1985a) and was summarized by Hall (1993) and by Pattrick and Treagus (1996). The consensus of this research was that the body is a sedimentary deposit, resulting from the exhalation of metalladen fluids onto the floor of a deep-sea basin. Other barium enrichments in the Ben Eagach Schist are now known near Braemar at Loch Kander (NO 192 803) and Allt an Loch (NO 196 796) (Gallagher et al., 1989) and near Loch Lyon (NN 414 383) (Coats et al., 1984). The body has been the subject of extensive underground and surface mining (Foss Mine) from 1984 to the time of writing (1999); the GCR site is largely comprised of the artificial exposures created by this mining activity.

\subsection{Description}

Natural exposures of the mineral body are generally poor, the most significant occurring on Creag an Chanaich (NN 8122 5457), in the Frenich Burn East (NN 8196 5492) and on Creag an Loch (NN 8267 5504). However, in the area of the GCR site, around Foss Mine, the body has been exposed extensively in opencast workings, along the access road on Creag an Chanaich and around the adits to the underground workings, especially on the north-eastern face of creag an Chanaich (Figure 51).

The total thickness of the mineral body reaches $80 \mathrm{~m}$, and the maximum thickness of baryte is $15 \mathrm{~m}$. It is hosted by the graphitic muscovite schist of the Ben Eagach Schist Formation and is close to, or at the contact with, the calcareous schist of the overlying Ben Lawers Schist. There are two main mineral horizons, the Upper and Lower horizons. The high-grade Upper Mineral Horizon is characterized by bedded pyritiferous baryte, generally bounded above and below by quartz-celsian (barium feldspar) rock, bariumenriched muscovite schist and sulphide-bearing graphitic schist. Layers of massive sulphide (pyrite, chalcopyrite, sphalerite and galena) are rare but significant components. The thicknesses and relative importance of the mineral lithologies vary considerably along strike and down dip, but the bedded baryte and the quartzcelsian rock are major components and this is one of the largest occurrences of celsian in the world. The description here is confined to the exposures on or near to the mine track at Creag an Chanaich and those in the opencast pits to the east (Figure 53).

The most westerly exposure of the body is seen on the western slope of Creag an Chanaich, where massive baryte of the Upper Mineral Horizon, dipping steeply to the south, is overlain by quartz-celsian rock at NN 8109 5461. On the ridge of Creag an Chanaich, between NN 81145459 and NN 8122 5457, the 3.5 m-thick baryte body, containing pyritic layers, is overlain by $1 \mathrm{~m}$ of siliceous schist and then by quartz-celsian rock. In this area, 8 $m$ of graphitic schist separate the Upper Mineral Horizon from the Ben Lawers Schist. On the steep, east slope of Creag an Chanaich, the surface trace of the mineral body is controlled by two WSWplunging regional fold sets; $F 2$ folds, which were originally upright, are here locally recumbent, having been affected by a 
major F3 fold-pair (Figure 52) that is well seen in the outcrop sub-parallel to the hairpin bends of the mine track, especially between NN 81285457 and NN 81315453 (Figure 51). One metre of baryte is here enclosed in an envelope of quartz-celsian rock, $2 \mathrm{~m}$ thick below and over $3 \mathrm{~m}$ thick above, which is affected by a F2 fold-pair (Figure 51). At NN 81355453 the baryte and quartzcelsian rock form the core of an F2 antiform. The more-penetrative S2 cleavage, as well as a superimposed well-developed upright S3 crenulation cleavage, is well seen in the schists adjacent to these folds. Within the outcrop of the Ben Eagach Schist in this area is a 3 m-thick, broadly concordant sheet of calcareous hornblende schist (a basic meta-igneous rock), which crosses the track in several places on the hairpin bends.

The mineral body is also well exposed in the western wall of the track, in a disused adit (NN 8135 5455). Here the baryte layer is $4 \mathrm{~m}$ thick, massive, white or grey depending on the concentration of pyrite layers and occupies the synformal core of an F2 fold. A 10 cm-thick layer of massive pyrite is present at the stratigraphical base of the baryte, in the north wall of the adit. To the east a further (lower) adit has been driven into the baryte, which is here $3.5 \mathrm{~m}$ thick in an envelope of quartz-celsian rock in an F3 antiformal structure. Farther down the track, the Ben Eagach Schist-Ben Lawers Schist contact is exposed (NN 8137 5450). A structural synthesis of these exposures in the mine track is shown in Figure 52 .

The Lower Mineral Horizon is also present on Creag an Chanaich, although it thins progressively eastwards (Figure 51). A small outcrop is present on the top of the ridge at NN 81225464 and comprises quartz-celsian rock with a sheet of heavily weathered calcareous hornblende schist (basic meta-igneous rock) at the base; the associated scree contains massive baryte. A trench by the track at NN 81245463 has exposed 2-3 m of pyritic quartz-celsian rock with $1 \mathrm{~m}$ of basic meta-igneous rock at the basal contact; the lithologies are repeated in an F3 fold core and the Ben Eagach Schist is exposed in the southerly end of the trench, in which a flat-lying crenulation cleavage (local S4) can be seen as well as D3 and D2 folds and cleavages. In the most-easterly exposure of the Lower Mineral Horizon, at NN $81335457,30 \mathrm{~cm}$ of pyritic quartz-celsian rock and sulphide-rich schist are found; here too the lower contact of the horizon is marked by a $50 \mathrm{~cm}$-thick sheet of basic meta-igneous rock.

The surface trace of the Upper Mineral Horizon is offset by a pair of NNE-trending, left-lateral faults that separate the underground workings from the opencast pits; the area between the faults is occupied by mine buildings and plant (Figure 51). The most easterly fault-plane is exposed in the western end of the opencast workings and contains an altered microdiorite dyke (NN 8144 5446). To the east of the fault, the mineral horizons have been mined in several pits, which are exploiting the thickest, near-surface occurrences of the baryte (Figures 51 and 52). In the southwestern part of the opencast workings, exploitation has focussed on baryte rock in the core of a southwards plunging F2 synform. On the southern limb of this synform the Ben Lawers Schist, the muscovitic, graphitic, Ben Eagach Schist and quartz-celsian rock 
are well exposed in the pit wall; the Ben Eagach Schist is also exposed in the core of the synform at NN 81475448 (Figure 53). An F3 antiformal structure causes the baryte and quartz-celsian rock to crop out again to the north at NN 8152 5450. To the east, the outcrop of the Upper Mineral Horizon is complicated by small NEtrending faults and F2/F3 folding and thins rapidly towards the Frenich Burn Fault.

\subsection{Interpretation}

The mineral body in the area of the GCR site is considered to be a SedEx-type (sedimentary exhalative) deposit (Coats et al., 1980; Willan and Coleman, 1983; Russell et al., 1984; Moles, 1985a; Hall, 1993). It is thought to have resulted from the exhalation of metal-laden mineralizing fluids onto the floor of a marine basin at the time of Easdale Subgroup sedimentation. The baryte formed by the mixing of barium, carried in reduced hydrothermal fluids, with sulphate in the relatively oxidized seawater. Barium also reacted with the aluminosilicate-rich seafloor muds to produce barian clays and cymrite $\left(\mathrm{BaAl}_{2} \mathrm{Si}_{2} \mathrm{O}_{8} \cdot \mathrm{H}_{2} \mathrm{O}\right)$, the precursors to the barian micas and barian feldspar (celsian), the transition taking place during metamorphism, with estimates of a pressure of 6.5 kbar and a temperature of $530^{\circ} \mathrm{C}$ (Moles, 1985b). The hydrothermal fluid was also the source of the metals for the sulphides and iron oxides but, in contrast to many SedEx deposits, these rarely formed thick accumulations. Exhalative silica precipitated as cherts in the aluminosilicate muds and recrystallized during metamorphism.

The mineral horizons are interpreted as successive exhalative hydrothermal pulses emanating onto the seafloor, the variation in the horizons being a function of both intensity of hydrothermal activity and the distance from exhalative centres. Although two of the horizons are laterally very extensive, occurring along the $2 \mathrm{~km}$ strike length in the GCR site area and extending for a further $7 \mathrm{~km}$ eastwards, the recognition of exhalative centres within these horizons has not proved possible. To explain the sharp contacts to the massive baryte layers, Russell et al. (1984) suggested that the sulphate for the baryte was derived from evaporitic shallow coastal areas which periodically produced flows of dense sulphate-rich brine into the sulphate-poor basin deeps at the time of hydrothermal activity, thus providing an episodic and finite sulphate supply.

The fundamental cause of the mineral influx is considered to be the crustal instability during Argyll Group times that resulted in the break-up of the Dalradian basin into several second-order basins (Coats et al., 1984; Russell et al., 1984; Pattrick and Treagus, 1996, figure 7b). The basic meta-igneous rocks of oceanic affinity in the Farragon Volcanic Formation overlying the Ben Lawers Schist are a product of the continuation of this process as the basins extended and deepened. The thick basic meta-igneous sheets in the mine area that post-date the mineralization are interpreted as sills and are also associated with this process. The crustal extension and thinning that led to the break-up of the basin resulted in a high geothermal gradient and large-scale convection of seawater into the underlying lithologies (to a depth 
of at least $10 \mathrm{~km}$ ) where it was heated by interaction with the buried older Dalradian lithologies. This fluid leached metals from the rocks (especially barium from the feldspathic Grampian Group), before rising to the seafloor to form the SedEx deposit. These same conditions prevailed over all of the Dalradian basins at this time and resulted in similar mineralization being developed in the Easdale Subgroup elsewhere.

In terms of the regional structure, the deposit lies on the steep, south-dipping limb of the major upward-facing Fl Creag an h-Iolaire Anticline (Treagus, 2000, figure 14); there is no significant mineral body on the north limb of this fold. Fl minor folds have not been recorded, but the structural relationships between the well-developed minor folds and cleavages of D2 and D3 age (as well as of the local D4) in the area of the GCR site are exceptionally clear. They also clearly reveal the geometry and superimposition of major folds of both D2 and D3 ages (Figure 52).

\subsection{Conclusions}

The Creag an Chanaich to Frenich Burn GCR site is of international importance in providing excellent exposure of a metamorphosed synsedimentary mineral body, which is unique in British and European geology and has few equals worldwide. The barium sulphate mineral baryte $\left(\mathrm{BaSO}_{4}\right)$, which forms a large proportion of the body in an unusually pure concentration, has been an important source of drilling mud for oil exploration in the North Sea. In addition it contains concentrations of sulphide minerals, as well as two unusual barium silicate minerals, celsian (barium feldspar) and cymrite (a hydrous aluminosilicate). The latter two minerals have been used to calculate the temperature and pressure (and hence the depth of burial) to which the Dalradian rocks were subjected during the creation of the mountain-belt; and this is one of the largest known ocurrences of celsian in the world.

The unique feature of this body is that it is of sedimentary origin, believed to have been precipitated directly from brines in a small marine basin, fed by metal-rich hot fluids percolating through the underlying sedimentary pile. The site also provides unusually clear minor structures (folds and cleavages) of two generations, which affect the mineral body and which have been used in the understanding of the geometry of some major folds that make up the Grampian fold-belt.

\section{AUCHTERTYRE} (NN 354 291-NN 368 312)

\section{R.A. Scott}

\subsection{Introduction}

The Auchtertyre GCR site, between Crianlarich and Tyndrum, contains the most extensive and most accessible exposures of stratabound sulphide mineralization in the Ben Challum Quartzite Formation, a unit of restricted distribution at the base of the Crinan subgroup. 
Characteristic features of the quartzites are distinctive minor folds with strongly curving axes, which are restricted in this area to this particular formation.

The Tyndrum area occupies an important position for structural and stratigraphical correlations with adjacent regions. However, until the 1980s, the area had remained essentially unmapped since the original survey of Sheet 46 (Balquhidder, 1900) by B.N. Peach and others. It was the discovery of stratabound units of sulphide mineralization as part of the Mineral Reconnaissance Programme of the Geological Survey that provided the main incentive for renewed stratigraphical and structural study (Smith et al., 1984, 1988; Fortey and Smith, 1986; Hall, 1993).

The new mapping in the Auchtertyre area revealed a thick sequence dominated by feldspathic quartzites, between the Ben Lawers Schist Formation and the Ben Lui Schist Formation (Figure 54a). This was named the Ben Challum Quartzite Formation and was considered to be equivalent to the Farragon Volcanic Formation at the top of the Easdale subgroup, a unit of amphibolites and quartzites, which in upper Glen Lyon has a maximum thickness of $25 \mathrm{~m}$. Subsequently it has been re-assigned to the Crinan Subgroup on sedimentological grounds, although it might merely reflect a diachronous facies variation and hence be broadly equivalent in time to the Farragon Formation. Scott (1987) showed that the Ben Challum Quartzite Formation forms a continuous mappable unit, which can be traced from the Tyndrum Fault to the Garabal Hill Fault, a total distance along strike of approximately $20 \mathrm{~km}$. The formation is restricted to the area bounded by these faults. A maximum thickness of $500 \mathrm{~m}$ is likely but the formation thins towards the east and possibly also in the west, close to the Tyndrum Fault. With the exception of the Ben Challum Quartzite Formation, the Argyll Group stratigraphy of the Tyndrum area is identical to that in areas to the south-west and north-east (Roberts and Treagus, 1979; Nell, $1984)$.

The principal exposures of the formation occur at Auchtertyre, where river sections drain south-westward into Strath Fillan from the watershed with Glen Lyon and Glen Lochay to the north-east (Figure 54a). Other than the river sections, most of the valley floors are filled with thick glacial till and moraine. Exposures also occur on the main peaks that form the watershed (e.g. Ben Challum, $1022 \mathrm{~m}$, NN 388 322) but in general these are not as easily accessible or as informative as the river sections.

\subsection{Description}

The GCR site encompasses three main river sections through the Ben Challum Quartzite Formation (Figure 54a): the Allt Gleann a' Chlachain, the Allt a' Chaol Ghlinne and, below the confluence of these two rivers, the Allt Auchtertyre. These rivers provide near continuous exposure through the entire formation at its thickest part.

The Ben Challum Quartzite Formation contains a variety of rock types but is dominated by well-bedded quartzites rich in plagioclase feldspar in the range albite-oligoclase. In some beds feldspar is more abundant than quartz (Scott et al., 1988). The 
rock is generally fine to medium grained, but locally contains coarser pebbly beds. Beds range in thickness up to $2 \mathrm{~m}$ but are usually less than $0.5 \mathrm{~m}$; bedding is normally continuous with no internal cut-offs and lacks recognizable way-up criteria. Individual beds are separated by micaeous layers (mainly muscovite) generally less than $10 \mathrm{~mm}$ thick. Rarely the rock as a whole becomes more pelitic and garnetiferous, and as such is then indistinguishable from the overlying Ben Lui Schist Formation. Conformable amphibolite units up to $2 \mathrm{~m}$ thick occur sporadically throughout the Ben Challum Quartzite Formation, and this contrasts with the Farragon Volcanic Formation, which is dominated by amphibolite. The fine-scale layering in some amphibolite units was clearly disrupted before the deformation described below. Several layers of calcareous semipelite up to $1 \mathrm{~m}$ thick form a minor component of the sequence (e.g. at NN 3601 3057), and minor occurrences of graphitic pelite occur in the lower part of the formation.

The Ben Challum Quartzite Formation contains two units of stratabound sulphide mineralization: the Auchtertyre Horizon and the overlying Ben Challum Horizon (Fortey and Smith, 1986; Smith et al., 1988; Scott et al., 1988, 1991). The weakly mineralized Auchtertyre Horizon is about $80 \mathrm{~m}$ thick in total; the best exposures are around the intersection of Allt Gleann a' Chlachain and the Allt $a^{\prime}$ Chaol Ghlinne (NN 3543 3023), and a further $100 \mathrm{~m}$ upstream in the Allt Gleann $a^{\prime}$ Chlachain (Figure 54a). Mineralization occurs as bedding-parallel sulphide laminae, up to $10 \mathrm{~mm}$ thick, in which pyrite predominates over minor chalcopyrite and sphalerite, and leads to a characteristic rusty weathering of the host quartzites. There are substantial thicknesses of nonmineralized quartzite in the total thickness.

The Ben Challum Horizon is approximately 20 - $30 \mathrm{~m}$ thick at the type locality on Ben Challum (NN 387 322) to the north-east of the GCR site, and on Creag Bhocan (NN 315 280), to the west of strath Fillan (Scott et al., 1988). It consists of layers of pyrite, chalcopyrite and sphalerite, up to $0.3 \mathrm{~m}$ thick, in chloritic schist and albitic quartzite. In the GCR site, the horizon is seen only as about $10 \mathrm{~m}$ of pyritized quartzite immediately below the top of the formation in the Allt Auchtertyre at NN 35413013.

An enigmatic unit of ultramafic rock characterizes the boundary between the Ben Challum Quartzite Formation and the overlying Ben Lui Schist Formation. It can be traced intermittently across the Tyndrum area, but exposure of this part of the succession is poor in the Allt Auchtertyre; the unit is best exposed on the flanks of Ben Challum and on Creag Bhocan (Scott et al., 1988). The variable mineralogy of the unit is compatible with an igneous origin and a subsequent high degree of alteration. It generally contains a combination of chlorite, ankerite, talc, fuchsite (chromian muscovite), quartz and amphibole, with accessory chromium- and zinc-bearing spinel, thiospinel, pyrite, pyrrhotite, pentlandite and millerite (Scott, 1987). The exposures in the Allt Auchtertyre occur close to the railway bridge and include chloritic schist containing carbonate porphyroblasts over $50 \mathrm{~mm}$ in diameter.

Two principal phases of ductile deformation are recorded in the Ben Challum Quartzite Formation. The most striking feature of the 
quartzites is the presence of non-cylindrical minor folds with strongly curving axes, of which numerous examples can be observed at all stratigraphical levels (Scott, 1987). The best examples occur within well-bedded feldspathic quartzites in which individual beds have constant thickness and are separated by thin partings of mica schist (Figure 55). Non-cylindrical minor folds do not occur in any of the adjacent formations.

The non-cylindrical folds are generally tight and fold hinges become more curved with a decrease in interlimb angle; a number of morphological types are present (Scott, 1987). The overall range of orientation of the hinges approaches $180^{\circ}$ (Figures 54b and 55) so that many hinges pitch down the dip of the schistosity. The effect of this is that subparallel hinges within a few metres of each other face in opposite directions. Exposed folds range in amplitude from tens of centimetres to 3 metres, but reversals of vergence indicate that the largest fold amplitudes must be of the order of $10-20 \mathrm{~m}$. The vergence of such reclined fold-pairs can be difficult to determine but, when 'restored' to a horizontal position, it can be ascertained that most fold-pairs, minor and major, verge to the south. Disharmonic folding affects sequences where there are marked differences in bed thickness and competence. In suitable pelitic lithologies a well-developed axial-planar crenulation schistosity is present. These folds affect the earlier bedding-parallel schistosity as well as, locally, a strong lineation of the quartz and feldspar fabric that is developed on that schistosity. Rarely, isoclinal folds of bedding are seen to pre-date the main fold set (Figure 56). No minor ductile structures post-dating the non-cylindrical folds were identified in the field, although several minor deformation phases have been identified elsewhere in the area (Scott, 1987).

A subvertical NNE-trending fault-system, named the Auchtertyre Fault, causes apparent sinistral displacement of the boundary between the Ben Challum Quartzite Formation and Ben Lui Schist Formation by as much as $800 \mathrm{~m}$ (Figure 54a). The fault can be observed in the Allt Auchtertyre.

\subsection{Interpretation}

The presence of layers of stratabound sulphide has promoted investigation of the Ben Challum Quartzite, both for scientific reasons, and in terms of its resource potential (e.g. Smith et al., 1984, 1988; Fortey and Smith, 1986; Fisk, 1986; Scott, 1987; Scott et al., 1988, 1991). Although no economic mineral occurrences have been discovered, the presence of this mineralization is important scientifically for two main reasons: (1) the nature of the mineralization provides information on the tectonic setting of sediment deposition and the geometry of depocentres; (2) stratabound mineralization is formed by relatively short-lived hydrothermal exhalation events on the sea floor. Geographically widespread mineralized units of limited thickness can therefore be regarded as time-lines in a succession otherwise devoid of chronostratigraphical control. In the Tyndrum area, the mineralization indicates a broad consistency between chronostratigraphy and lithostratigraphy. 
The sediments that formed the Argyll Group are generally considered to have been deposited in an actively extending basin (e.g. Anderton, 1982), and there are clear indications of synsedimentary faulting at a number of levels within the Argyll Group succession in the area surrounding Auchtertyre. The evidence comes from the nature and geometry of sediment packages, the distribution of stratabound mineralization, and the metal zonation within individual mineralized layers (Scott, 1987). The exact position and original orientation of the bounding faults is difficult to constrain because of the subsequent multiphase deformation history. However, all the evidence is consistent with a fault-bounded depression in the Tyndrum area that most probably had a half-graben geometry with the controlling fault on the northwest side. The presence of a fault-bounded basin is the principal reason why the Ben Challum Quartzite Formation accumulated only in this area, and why exhalative submarine brines were also ponded in the same depocentre.

Although the evidence for active extension during Argyll Group sedimentation is convincing, the tectonic setting in which it took place has been disputed, and has ranged from a marginal basin setting (e.g. Wright, 1976; Henderson and Robertson, 1982; Nell, 1984) to an intracontinental basin setting (e.g. Phillips et al. 1976; Harris et al., 1978). There are two principal strands of evidence from the Ben Challum Quartzite Formation that can be used to imply an arc-related marginal basin setting.

(1) A major change of sandstone provenance in the Dalradian succession appears to occur between the deposition of the Carn Mairg Quartzite and earlier formations, in which K-feldspar is the dominant feldspar, and the Ben Challum Quartzite and later formations, in which plagioclase is the dominant feldspar. It is no coincidence that this change occurs across an interval of the succession characterized by the onset of extension, stratabound mineralization and significant magmatism.

The albite-rich composition of the Ben Challum Quartzite Formation has led to speculation that the sequence may include keratophyre tuffs (Fortey and Smith, 1986; Fisk, 1986). No textural evidence now remains for a direct igneous origin but, considering the high plagioclase content, it does not seem unreasonable to conclude that the Ben Challum Quartzite Formation was derived by erosion of igneous rocks of silicic to intermediate composition, possibly with a direct volcanic input. A preliminary whole-rock geochemical study of psammites from the Ben Challum Quartzite Formation is consistent with a back-arc or continental margin arc setting (Scott, 1987).

The mineralogy of the apparently conformable ultramafic unit at the top of the Ben Challum Quartzite Formation is compatible with an igneous origin, and represents a more-intense state of alteration than serpentinization (Scott, 1987). The chemistry is also consistent with an origin as an igneous body, or as a sedimentary derivative, which was hydrothermally altered on, or close to, the seabed. More-definite conclusions about the unit's origin are precluded by the degree of alteration, but the presence of ultramafic rocks is compatible with an extensional setting in a marginal, possibly back-arc basin. 
(2) The base-metal content of the mineralized layers in the Ben Challum Quartzite Formation is indicative of volcanic-associated massive sulphide (VMS) deposits, an unsurprising interpretation considering the abundant evidence for magmatic activity in the host succession. The extreme length/thickness ratio of the mineralized units in the Ben Challum Quartzite Formation, and the absence of an Fe-Mn-oxide or baryte facies, suggests similarities with Besshi deposits, a type of arc-related VMS deposit described from Japan (Scott et al., 1988, 1991).

The closely packed, non-cylindrical minor folds, with strongly curving hinges (Figure 55), occur in this area only in the Ben Challum Quartzite Formation. These folds refold an earlier set of fold hinges as well as the earliest (S1) schistosity and are associated with a tight crenulation cleavage and garnet growth. They can be clearly correlated with the main regional D2 deformation phase. The entire outcrop of the Ben Challum Quartzite Formation lies on the right-way-up limb shared by the F2 Dalmally Antiform to the south (Figure 54a) and the F2 Ra Creag Synform to the north (Roberts and Treagus, 1975). This is supported by the dominant southerly vergence sense of minor fold-pairs observable at the site. The axial-plane traces of the major folds trend ENE, and rocks on the shared limb generally dip at moderate angles to the south. The geometrical relationships between the isoclinal folds and mineral lineations that pre-date the dominant D2 set (Figure 56) are not clear, but both are interpreted to be of the regional D1 phase, and related to the regional major F1 fold, the Ardrishaig Anticline (Roberts and Treagus, 1975).

The origin of the non-cylindrical folds with curving axes is not entirely clear. Many other examples of such folds have been ascribed to their occurrence in zones of extreme strain; however, this does not appear to be the case at Auchtertyre. Here, two factors are considered to be important: (1) the mechanical properties of the quartzite; and (2) the position of the outcrop relative to major D2 structures (Scott, 1987).

The presence of competent quartzite beds separated by thin pelitic partings has led to pronounced strain partitioning as beds moved relative to each other during folding (Scott, 1987). Internally, the quartzite beds were not subjected to intense stretching; pebbly beds, for example, do not show any significant elongation of clasts, which commonly show only a weak flattening in the approximate plane of bedding. It is not uncommon to find S1 fabric elements preserved within quartzite beds. In contrast, pronounced mineral lineations formed by microboudinaged garnet crystals within the pelitic seams indicate high D2 strain. This interbed slip was promoted both by the continuous nature of the bedding and by the overall structural position on a major $\mathrm{F} 2$ fold limb. In this location, it can be assumed that the principal D2 elongation direction would lie close to the average plane of layering, thus enhancing the tendency for layer-parallel shear.

As folding progressed, the initiation of minor folds in individual quartzite beds was impeded by adjacent beds, from which they were separated by a minimal thickness of pelitic material. In a succession where interbed slip was likely, the presence of F2 buckles or existing $F 1$ hinges would cause variations in cohesion 
and heterogeneous strain, thus providing a mechanism by which noncylindrical hinges could develop. There is no evidence to suggest significant transection of axial planes by the schistosity associated with the folds, which elsewhere has been reported to be a feature of this style of folding (Treagus and Treagus, 1981).

\section{4 Conclusions}

The Auchtertyre GCR site illustrates a style of stratabound sulphide mineralization that is unknown elsewhere in the Dalradian of Scotland. The mineralization occurs within the Ben Challum Quartzite Formation, a unit restricted to the Tyndrum area, which is important scientifically because of the insight it provides into the depositional settings of Argyll Group sediments. There is clear evidence that faults were active during deposition, that they acted as conduits for mineralizing fluids, and that they created the topography necessary to pond the fluids once they had been exhaled onto the sea bed. Contemporaneous magmatic activity provided the source of heat required to circulate the fluids through crustal rocks beneath the sea floor, where they were able to gather base metals such as copper and zinc. The chemistry and geometry of the mineralized units, combined with the mineralogy of their host sediments, suggest an island-arc-related tectonic setting.

An additional feature of the Ben Challum Quartzite Formation is the presence of well-exposed minor folds with exceptionally curved hinges, a feature found in this area only in this formation. The distinctive folds are thought to reflect the mechanical properties of the unusually well-bedded quartzites, which were able to slip relative to each other along intervening micaceous seams. The minor folds in the section also provide important information concerning the geometry of the major regional folds of the area.

This GCR site provides the only section through the entire Ben Challum Quartzite Formation and offers an excellent opportunity for further research into both stratabound mineralization and fold mechanisms.

\section{BEN OSS}

\section{(NN $291 \quad 265-$ NN 296 271)}

\section{J.E. Treagus}

\subsection{Introduction}

The Ben OsS GCR site has been selected to exemplify the fracture history of the Tyndrum Fault, one of the major system of NEtrending, dominantly left-lateral faults that dissect the Grampian Terrane between the Great Glen and the Highland Boundary faults (Figure 1 and Stephenson et al., 2013a, fig. 1). The principal period of fault movement was in the late silurian and is closely associated with Caledonian intrusions, such as the adjacent Garabal Hill-Glen Fyne granitic pluton and microgranite and appinitic microdiorite dykes in the Tyndrum area. Late-Carboniferous quartz- 
dolerite dykes, with a regional east to east-north-east trend, cut across the fault-zone.

Previous studies have established the strike-slip component of movement on this system of faults, although the importance of dipslip components has also been recognized (Anderson, 1951; Johnstone and Wright, 1957; Pitcher, 1967). Treagus (1991) constructed geological profiles on either side of some of the principal fault planes within the Grampian Terrane to demonstrate that the components of movement on the individual faults were both leftlateral strike-slip (up to $8 \mathrm{~km}$ ) as well as dip-slip (up to $2 \mathrm{~km}$ ). The Tyndrum Fault, in particular, was shown to have a significant dip-slip component of $2 \mathrm{~km}$, down to the east, as well as a leftlateral strike-slip component, which is greatest $(4 \mathrm{~km})$ in the central portion of the fault, the area of this GCR site. Treagus et al. (1999) have made a detailed study of the fault and its associated mineralization.

\subsection{Description}

This GCR site, which lies some $4 \mathrm{~km}$ south-west of the village of Tyndrum, occupies a gully of the Allt Coire Chruinn, which drains the northern slopes of Ben Oss (Figure 57). On these slopes, one major fault and many minor fractures associated with the Tyndrum Fault are particularly well exposed. The fault, termed here the Ben Oss Fault, can be traced from NN 295269 into good exposures in the $300 \mathrm{~m}$-long gully in the Allt Coire Chruinn at NN 291265 to the south-west. It is a major splay of and is very close to the line of the Tyndrum Fault, which in the area of the site is occupied by a microdiorite dyke.

At the north-east end of the gully, a quartz reef is exposed for $100 \mathrm{~m}$ in the hanging wall of the fault, which here trends $040^{\circ}$ and dips at $72^{\circ}$ to the south-east. To the south-west the reef becomes a breccia, composed of clasts of vein-quartz, $1-15 \mathrm{~cm}$ in length, in a cataclastic matrix of indurated fine-grained quartz and micas, evidence of extensional opening of the fault. In the wall formed by the margin of the breccia, many fault-parallel fractures are seen. These are marked by horizontal grooves, confirming strikeslip movement, and by a series of steeply N-pitching pinnate fractures, whose geometry indicates left-lateral movement. Many steep SE-dipping fractures are seen in the footwall of the fault (the north-west side of the gully), comprising both a faultparallel set and another set orientated some $10-25^{\circ}$ anticlockwise to the fault. The former are interpreted as $Y$ shears, the latter as $R$ shears, both with movement senses sympathetic to that of the main fault (see Sibson, 1977). In the schists in the footwall, 2-3 $m$ to the west of the fault plane, small-scale, steeply plunging, drag-folding of bedding also indicates left-lateral movement.

There is also evidence of left-lateral movement in the area immediately to the north-west of the fault gully. Here, major fractures can be seen on the aerial photographs, branching at some $20^{\circ}$ anticlockwise from the fault at regular $50 \mathrm{~m}$ intervals for several hundred metres to the north of the gully (Figure 58). The fractures contain both illite-quartz and pyritic gouges with textures indicating left-lateral movement. One major fracture at 
NN 2925 2677, occupied by the stream, contains a 3 m-thick quartzvein breccia, kink folds and bedding offsets in the schists that show clear left-lateral displacements (Figure 57, locality marked X and to its south-west). Slickensides and grooves (localities marked $S$ on Figure 57) plunge at an average of $2^{\circ}$ towards $221^{\circ}$ on the fault-parallel fractures, and at $7^{\circ}$ towards $197^{\circ}$ on the anticlockwise set, confirming the dominant strike-slip movement sense. The anticlockwise set of fractures is not seen to the south-east of the fault.

However, there is also evidence of right-lateral movement on the fault. Measurements of bedding to the west of and adjacent to the fault, at about NN 292 267, show a 100 m-wide fold plunging at $43^{\circ}$ towards $188^{\circ}$, the sense of deflection indicating right-lateral shear. Moreover, the swing in strike of the regional bedding, where followed for $1 \mathrm{~km}$ to the west of the fault, shows a similar pattern that also indicates a right-lateral deflection. Small right-lateral displacements and kinks have also been observed on some anticlockwise fractures (e.g. the two localities indicated on Figure 57), suggesting re-activation, and a $30 \mathrm{~cm}$-wide Caledonian dyke at NN 291265 shows both left-lateral and right-lateral metrescale displacements. The north-western margin of the dyke that occupies the Tyndrum Fault shows effects of further brecciation, shearing and hydrothermal alteration (e.g. at NN 295 270), which could represent this right-lateral movement. A thick lateCarboniferous dyke shows a slight dextral deflection where it crosses the fault at NN 296271.

\subsection{Interpretation}

Regional considerations suggest that the earliest movement on the Tyndrum Fault may have been a tensional opening as a normal fault (see Treagus et al., 1999); this is supported by the $70^{\circ}$ dip of the Ben Oss Fault and associated fractures, as well as by the hydrothermal breccias. Two fracture sets are evident in the GCR site, a fault-parallel set and another some $10-25^{\circ}$ anticlockwise to the fault (Figure 58); these are interpreted as $Y$ shears and $R$ shears, respectively, with sympathetic left-lateral shear in response to movement on the major fracture, in the traditional manner of fault analysis (Sibson, 1977). Many fault-related features on minor fractures (pinnate structures, kink-folds, bedding displacements and gouge textures) support the left-lateral displacements. Thus the Ben oss Fault can be confidently interpreted as a major fault with left-lateral displacement.

The principal evidence for the magnitude of the left-lateral displacement comes from the offset of the Ben Lawers Schist/Ben Lui Schist junction. On the west side of the Ben Oss Fault, this junction trends $040^{\circ}$ and dips steeply to the south-east; it is apparently displaced by some $3 \mathrm{~km}$ on the east side of the fault to near Cononish (Figure 57, inset). However, Treagus (1991, figure 3) showed that the latter occurrence of the junction represents the limb of a major F2 fold (a component of the regional Ben Lui Fold) that is structurally lower than the junction on the western side of the fault; the two fold limbs have been brought together by 
movements which had components of displacement of $1.8 \mathrm{~km}$ dip-slip (down to the east) and about $4 \mathrm{~km}$ left-lateral strike-slip.

Evidence for significant right-lateral movement in the fault-zone can also be established from the displacement of the Ben Lawers Schist/Ben Lui Schist junction in the Ben Oss area. There is a narrow sliver of Ben Lawers Schist directly east of the Ben Oss Fault, in which the junction is shifted some $300 \mathrm{~m}$ to the southwest (Figure 57). This sliver is separated from the Ben Lui schist farther east by a 14 m-wide, steeply SE-dipping, Caledonian dyke of porphyritic microdiorite. This dyke must be intruded along the major displacement plane of the Tyndrum Fault-zone, immediately east of the Ben Oss Fault. The interpretation of the movement history of the zone is shown in the inset to Figure 57. The early major movement displaced the Ben Lawers Schist/Ben Lui Schist junction as described above (with components of displacement up to $8 \mathrm{~km}$ in a left-lateral sense and $1.8 \mathrm{~km}$ of dip-slip) from its position at Cononish to that in the fault-bounded sliver. The main fault plane was then intruded and sealed by the microdiorite dyke, which is evidence of further extensional opening. A later rightlateral movement occurred on the Ben Oss Fault, which brought the Ben Lawers Schist/Ben Lui Schist junction back to its present position west of the faults. The Ben Oss Fault is therefore interpreted as a major splay of the Tyndrum Fault, having an unknown amount of left-lateral shear, but with a subsequent rightlateral movement of at least $300 \mathrm{~m}$

There is no evidence of the early precious-metal-type mineralization, seen elsewhere in the Tyndrum area, apart from minor pyrite mineralization on the faults and minor fractures. However, the later right-lateral movements are equated with those at other localities in the Tyndrum area, where they are associated with the base-metal mineralization (Treagus et al., 1999).

\subsection{Conclusions}

The Ben Oss GCR site provides exceptional exposures of a major fault, the Ben Oss Fault, together with associated minor and major fractures. Many of the features associated with major faults are well displayed, such as fault breccias, fault-gouge clays, slickensides and quartz veins. The fault is a component of the Tyndrum Fault, also exposed at this site, which is one of the major dislocations that traverse the Grampian Terrane from north-east to south-west.

Evidence from the exposed fault planes, together with that seen on aerial photographs, allows the movement sense on the major structure to be predicted. Both faults have a complex history, which principally involved a left-lateral sense of movement, such that the north-west side of the faults moved sideways to the southwest; the Ben Oss Fault probably only moved a few hundred metres but the Tyndrum Fault moved a minimum of $4 \mathrm{~km}$ and possibly as much as $8 \mathrm{~km}$. The evidence also suggests that the history of the faults, involved sideways movement in the opposite (right-lateral) sense, as well as vertical movements. Regionally these movements can be linked to the history of mineralization in the area. 


\section{ACKNOWLEDGEMENTS}

This regional paper is the combined work of 5 authors, many of whom, in addition to their own site descriptions, have made valuable comments on other aspects of the work. Sadly, Peter Thomas died whilst this special issue was being prepared for final submission. He made major contributions to his own areas of the Dalradian outcrop and to our overall understanding of Grampian Highland geology.

The paper has been compiled by J.E. Treagus and has been edited by D. Stephenson. S.H. Treagus is thanked for additional comments. The GCR editor was P.H. Banham and the referee was M.R.W. Johnson, who also provided valuable editorial suggestions. The project was cofunded by the Joint Nature Conservation Committee (JNCC) and the British Geological Survey (BGS) and has been managed by N.V. Ellis for JNCC and D.J. Fettes and M. Smith for BGS.

The initial site selection and site documentation for the Dalradian block of the Geological Conservation Review was by S.J. Moorhouse. Since then, much new mapping and refined interpretation has taken place, and the site list has been revised, firstly by J.E. Treagus and subsequently through a panel consisting of $R$. Anderton, A.L. Harris, J.R. Mendum, J.L. Roberts, P.W.G. Tanner, R. Threadgould and J.E. Treagus. The necessary amendments to the GCR documentation were greatly facilitated by R. Wignall (for Scottish Natural Heritage).

K.M. Goodenough and S.W. Horsburgh assisted with preliminary drafts of key maps and all diagrams were drafted for publication by S.C. White (JS Publications, Newmarket) and K.J. Henderson (BGS, Edinburgh). Photographs were scanned and prepared by B.M. McIntyre (BGS, Edinburgh). Photographs from the BGS collection are reproduced by kind permission of the Director, BGS () Natural Environment Research Council; all rights reserved (PR/23-27).

The first complete draft of the Dalradian GCR was submitted to the JNCC in June 2009. In 2010, the JNCC terminated its involvement in Earth Science conservation and abandoned its contractual agreements to publish the remaining GCR volumes. So, the authors are greatly indebted to Diarmad Campbell, Chief Geologist Scotland for the BGS, for funding the drafting of remaining figures and to the Geologists' Association and Elsevier, for ensuring that this volume is published as a special Issue of their Proceedings. We are particularly grateful to Neil Ellis of the JNCC for his efforts to secure a new publisher and to Professor James Rose, Editor in Chief of the PGA, for making it all happen.

Finally, on behalf of all of the site authors, we would like to record our thanks to the owners and managers of land and quarries who have allowed access to the sites, either during previous work or specifically for the GCR exercise.

\section{REFERENCES}

Agrell, S. O. (1942) 1. A petrological investigation of the adinoles at Dinas Head, Cornwall. 2. A petrofabric study of the 
Ben Vuroch granite and the adjacent schists in Perthshire. Unpublished PhD thesis, University of Cambridge.

Ahmed-Said Y. and Tanner P. W. G. (2000) P-T conditions during emplacement, and D2 regional metamorphism, of the Ben Vuirich Granite, Perthshire, Scotland. Mineralogical Magazine, 64, 737-53.

Ague, J.J. \& Baxter, E.F., 2007. Brief thermal pulses during mountain building recorded by Sr diffusion in apatite and multicomponent diffusion in garnet. Earth and Planetary Science Letters, 261, 500-516.

Allen, J. R. L. 1963. The classification of cross stratified units with notes on their origin. Sedimentology, 2, pp. 93-114.

Allison, A. (1933) The Dalradian succession in Islay and Jura. Quarterly Journal of the Geological Society, London, 89, 125-44.

Allison, A. 1941. Loch Awe succession and tectonics-KilmartinTayvallich-Danna. Quarterly Journal of the Geological Society, London, 96, 423-49.

Allison, I., May, F and Strachan, R.A. (1988) An Excursion guide to the Moine Geology of the Scottish Highlands. Scottish Academic Press for Edinburgh Geological Society and Geological Society of Glasgow.

Alsop, G.I. and Hutton, D.H.W. (1990) A review and revision of Dalradian stratigraphy in central and southern Donegal, Ireland. Irish Journal of Earth Sciences, 10, 181-98.

Alsop, G.I., Prave, A.R., Condon, D.J. and Phillips, C.A. (2000) Cleaved clasts in Dalradian conglomerates: possible evidence for Neoproterozoic compressional tectonism in scotland and Ireland? Geological Journal, 35, 87-98.

Amos, B.J. (1960). The geology of the Bowmore district, Islay. Unpublished PhD thesis, University of London, Imperial College.

Anderson, E M. (1923). The geology of the schists of the Schiehallion district. Quarterly Journal of the Geological Society of London, 79, 423-45.

Anderson, E M. (1951) The Dynamics of Faulting. (Second edition). (Edinburgh: Oliver and Boyd.)

Anderson, J. G. C., (1942) The stratigraphical order of the Dalradian schists near the Highland Border in Angus and Kincardineshire. Transactions of the Geological Society of Glasgow, 20, 223-37.

Anderson, J.G.C. (1947a) The geology of the Highland Border, Stonehaven to Arran. Transactions of the Royal Society of Edinburgh, 61, 479-515.

Anderson, J.G.C. (1947b) The Kinlochlaggan Syncline, southern Inverness-shire. Transactions of the Geological Society of Glasgow, 21, 97-115.

Anderson, J.G.C. (1948) Stratigraphic nomenclature of Scottish metamorphic rocks. Geological Magazine, 85, 89-96.

Anderson, J.G.C (1956). The Moinian and Dalradian rocks between Glen Roy and the Monadhliath Mountains, Inverness-shire. Transactions of the Royal Society of Edinburgh, 63, 15-36.

Anderton, R. (1974) Middle Dalradian sedimentation in Argyll, with particular reference to the Jura quartzite, Scarba conglomerate and Craignish phyllites. Unpublished PhD thesis, University of Reading.

Anderton, R. (1975) Tidal flat and shallow marine sediments from the Craignish Phylites, Middle Dalradian, Argyll, Scotland. Geological Magazine, 112, 337-40. 
Anderton, R. (1976) Tidal-shelf sedimentation: an example from the Scottish Dalradian. Sedimentology, 23, 429-58.

Anderton, R. (1977) The Dalradian rocks of Jura. Scottish Journal of Geology, 13, 135-42.

Anderton, R. (1979) Slopes, submarine fans and syn-depositional sedimentology of parts of the Middle and Upper Dalradian in the S.W. Highlands of Scotland. In The British Caledonides - Reviewed (eds. Harris, A. L., Holland, C. H. and Leake, B. E.), Geological Society, London, Special Publications, 8.

Anderton, R. (1980). Distinctive pebbles as indicators of Dalradian provenance. Scottish Journal of Geology, 16, 143-52.

Anderton, R. (1982) Dalradian deposition and the late Precambrian Cambrian history of the $\mathrm{N}$ Atlantic region: a review of the early evolution of the Iapetus ocean. Journal of the Geological Society of London, 139, 421-31.

Anderton, R. (1985) Sedimentation and tectonics in the Scottish Dalradian. Scottish Journal of Geology, 21, 407-36.

Anderton, R. (1988) Dalradian slides and basin development: a radical interpretation of stratigraphy and structure in the SW and Central Highlands of Scotland. Journal of the Geological society of London, 145, 669-78.

Arndt, N.T. and Nisbet, E.G. (editors) (1982) Komatiites. George Allen and Unwin, London.

Ashcroft W.A., Kneller B.C., Leslie, A.G. and Munro M. (1984) Major shear zones and autochthonous Dalradian in the northeast Scottish Caledonides. Nature, London 310, 760-2.

Ashworth, J.R. (1972) Migmatites of the Huntly-Portsoy area, northeast Scotland. Unpublished PhD thesis, University of Cambridge.

Ashworth, J.R. (1975) The sillimanite zones of the Huntly-Portsoy area in the north-east Dalradian, Scotland. Geological Magazine, $112,113-224$.

Ashworth, J.R. (1976) Petrogenesis of migmatites in the HuntlyPortsoy area, north-east Scotland. Mineralogical Magazine, 40, 661-82.

Ashworth, J.R. (1979) Comparative petrography of deformed and undeformed migmatites from the Grampian Highlands of Scotland. Geological Magazine, 116, 445-56.

Astin, T.R. and Rogers, D.A. (1991) 'Subaqueous shrinkage Cracks' in the Devonian of Scotland re-interpreted. Journal of Sedimentary Petrology, 61, 850-9.

Atherton, M.P. (1977) The metamorphism of the Dalradian rocks of Scotland. Scottish Journal of Geology, 13, 331-70.

Atherton, M.P., and Brotherton, M.S. (1972) The composition of some kyanite-bearing regionally-metamorphosed rocks from the Dalradian. Scottish Journal of Geology, 8, 203-13.

Atherton, M.P. and Ghani, A.A. (2002) Slab breakoff: a model for Caledonian, Late Granite syn-collisional magmatism in the orthotectonic (metamorphic) zone of Scotland and Donegal. Lithos, 62, $65-85$.

Bailey, E.B. (1910) Recumbent folds in the schists of the Scottish Highlands. Quarterly Journal of the Geological Society of London, 66, 586-620.

Bailey, E. B. 1913. The Loch Awe Syncline (Argyllshire). Quarterly Journal of the Geological Society of London, 69, 280-307.

Bailey, E.B. (1917) The Islay anticline (Inner Hebrides). Quarterly Journal of the Geological Society of London, 72, 132-64. 
Bailey, E.B. (1922) The structure of the South West Highlands of Scotland. Quarterly Journal of the Geological Society of London, 78, 82-131.

Bailey, E.B. (1925) Perthshire tectonics: Loch Tummel, Blair Atholl and Glen Shee. Transactions of the Royal society of Edinburgh, 53, 671-98.

Bailey, E.B. (1930) New Light on Sedimentation and Tectonics. Geological Magazine, 67, 77.

Bailey, E.B. (1934) West Highland tectonics: Loch Leven to Glen Roy. Quarterly Journal of the Geological Society of London, 90, 462-523.

Bailey, E.B. (1938) Eddies in mountain structure. Quarterly Journal of the Geological Society of London, 94, 607-25.

Bailey, E B. (1953). Facies changes versus sliding: Loch Leven, Argyll. Geological Magazine, 90, 111-13.

Bailey, E.B. (1960) The geology of Ben Nevis and Glencoe and the surrounding country. (2nd edition). Memoir of the Geological Survey of Great Britain, Sheet 53 (Scotland).

Bailey, E.B., and McCallien, W. (1937). Perthshire tectonics: Schiehaliion to Glen Lyon. Transactions of the Royal Society of Edinburgh, 59, 79-118.

Bailey, E B, and MacGregor, M. 1912. The Glen Orchy Anticline, Argyllshire. Quarterly Journal of the Geological Society of London, Vol. 68, 164-179.

Bailey, E.B., and Maufe, H.B. (1916) The geology of Ben Nevis and Glen coe and the surrounding country. (1st edition). Memoir of the Geological Survey of Great Britain, Sheet 53 (Scotland).

Bain, J.A., Briggs, D.A. and May, F. (1971) Geology and mineralogical appraisal of an extensive talc-magnesite deposit in the Shetlands. Transactions of the Institute of Mining and Metallurgy, 80, B77-B84.

Baker, A.J. (1985) Pressures and temperatures of metamorphism in the eastern Dalradian. Journal of the Geological Society of London, 142, 137-48.

Baker, A.J. (1987) Models for the tectonothermal evolution of the eastern Dalradian of Scotland. Journal of Metamorphic Geology, 5, $101-18$.

Baker, A.J., and Droop, G.T.R. (1983) Grampian metamorphic conditions deduced from mafic granulites and sillimanite-Kfeldspar gneisses in the Dalradian of Glen Muick, Scotland. Journal of the Geological Society of London, 140, 489-97.

Baldwin, C.T. and Johnson, H.D. (1977) The Dalradian rocks of Lunga, Luing and Shuna. Scottish Journal of Geology, 13, 143-54.

Banks, C. J. (2005). Neoproterozoic Basin Analysis: a combined sedimentological and provenance study in the Grampian Group, Central Highlands, Scotland. Unpublished PhD Thesis, University of Keele.

Banks, C.J. (2007) Exceptional preservation of sedimentary structures in metamorphic rocks: an example from the upper Grampian Group, Creag Stalcair, Perthshire. Scottish Journal of Geology, 43, 9-14.

Banks, C.J. and J.A. Winchester (2004). Sedimentology and stratigraphic affinities of Neoproterozoic coarse clastic successions, Glenshirra Group, Inverness-shire Scotland. Scottish Journal of Geology 40, 159-174.

Banks, C.J., Smith, M., Winchester, J.A., Horstwood, M.S.A., Noble, S.R. and Ottley, C.J. (2007) Provenance of intra-Rodinian basin- 
fills: the lower Dalradian Supergroup, Scotland. Precambrian Research, 153, 46-64.

Barreiro, B.A. (1998) U-Pb systematics on zircon from the Keith and Portsoy granites, Grampian Highlands, Scotland. NERC Isotope Geosciences Laboratory Report Series No. 132.

Barrow, G. (1893) On an intrusion of muscovite-biotite gneiss in the south-east Highlands of Scotland, and its accompanying metamorphism. Quarterly Journal of the Geological Society of London, 49, 330-58.

Barrow, G. (1904) Moine gneisses of the east central Highlands and their position in the Highland sequence. Quarterly Journal of the Geological Society of London, 60, 400-44.

Barrow, G. (1912) On the geology of Lower Deeside and the southern Highland border. Proceedings of the Geologists' Association, 23, 274-90.

Barrow G. and Cunningham Craig E.H. (1912) The geology of the districts of Braemar, Ballater and Glen Clova. Memoir of the Geological Survey of Great Britain, Sheet 65 (Scotland).

Barrow, G, Grant Wilson, J S, and Cunningham Craig, E H. (1905). The geology of the country around Blair Atholl, Pitlochry and Aberfeldy. Memoir of the Geological Survey of Great Britain, Sheet 55 (Scotland).

Basahel, A.N. (1971) The Dalradian stratigraphy and structure of southern Islay, Argyll. Unpublished PhD thesis. University of Liverpool.

Batchelor, R.A. (2011) Geochemistry of Torridonian tuffs and contemporary phosphorites; potential for correlation of Torridonian sequences in NW Scotland. Scottish Journal of Geology, 47, 133-142.

Baxter, E.F., Ague, J.J. and Depaolo, D.J. (2002) Prograde temperature-time evolution in the Barrovian type-locality constrained by $\mathrm{Sm} / \mathrm{Nd}$ garnet ages from Glen Clova, Scotland. Journal of the Geological Society, London, 159, 71-82.

Beddoe-Stephens B. (1990) Pressures and temperatures of Dalradian metamorphism and the andalusite-kyanite transformation in the northeast Grampians. Scottish Journal of Geology 26, 3-14.

Bell, A. M. (1981) Vergence: an evaluation. Journal of Structural Geology, Volume 3, 197-202.

Bendall, C.A. (1995). A geochronological, structural and metamorphic study of rocks from the central and SW Dalradian of Scotland. Unpublished PhD thesis, University of Manchester

Bentley, M.R. (1986) The tectonics of Colonsay, Scotland. Unpublished PhD thesis, University of Wales, Aberystwyth.

Bentley, M.R. (1988). The Colonsay Group. In Winchester, J.A (ed.) Later Proterozoic stratigraphy of the Northern Altlantic Regions. Blackie and Son Ltd., London, 119-30.

Bentley, M.R., Maltman, A.J., and Fitches, W.R. (1988) Colonsay and Islay: a suspect terrane within the Scottish Caledonides. Geology, 16, 26-8.

Bingen B., Demaiffe D. and van Breemen O. (1998) The $616 \mathrm{Ma}$ old Egersund basaltic dyke swarm, SW Norway, and late Neoproterozoic opening of the Iapetus Ocean. Journal of Geology, 106, 565-74.

Bingen, B., Griffin, W.L. Torsvik, T.H. and Saeed, A. (2005) Timing of late Neoproterozoic glaciation on Baltica constrained by detrital zircon geochronology in the Hedmark Group, south-east Norway. Terra Nova, 17, 250-58. 
Bliss, G.M. (1977) The micropalaeontology of the Dalradian. Unpublished PhD thesis, University of London, Imperial College.

Bluck, B.J. (1983) Role of the Midland Valley of Scotland in the Caledonian Orogeny. Transactions of the Royal Society of Edinburgh: Earth Sciences, 74, $119-136$.

Bluck, B.J. (1984) Pre-Carboniferous history of the Midland Valley of Scotland. Transactions of the Royal Society of Edinburgh: Earth Sciences, 75, 275-95.

Bluck, B.J. (2000) 'Where ignorance is bliss 'tis a folly to be wise' (Thomas Gray 1716-1761) - controversy in the basement blocks of Scotland. Scottish Journal of Geology, 36, 97-101.

Bluck, B.J. (2001) Caledonian and related events in Scotland. Transactions of the Royal Society of Edinburgh: Earth Sciences, $91,375-404$.

Bluck, B.J. (2002) The Midland Valley Terrane. In: Trewin, N.H. (ed.) The Geology of Scotland. The Geological Society, London, $149-66$.

Bluck, B.J. (2010) The Highland Boundary Fault and the Highland Boundary Complex. Scottish Journal of Geology, 46, 113-124.

Bluck B.J. and Dempster T.J. (1991) Exotic metamorphic terranes in the Caledonides: tectonic history of the Dalradian block, Scotland. Geology, 19, 1133-6.

Bluck B.J., Dempster T.J., and Rogers G. (1997) Allochthonous metamorphic blocks on the Hebridean passive margin, Scotland. Journal of the Geological Society of London 154, 921-4.

Bluck, B.J., Gibbons, W. and Ingham, J.K. (1992). Terranes. 1-4 in Atlas of palaeogeography and lithofacies. Cope, J.C.W., Ingham, J.K., and Rawson, P.F. (editors). Geological Society of London Memoir, No. 13.

Bluck B.J., Halliday A. N., Aftalion M., and Macintyre R.M. (1980) Age and origin of the Ballantrae ophiolite and its significance to the Caledonian orogeny and Ordovician time scale. Geology 8, 49295 .

Bluck, B.J. and Ingham, J.K. (1997) The Highland Border controversy: a discussion of "New evidence that the Lower Cambrian Leny Limestone at Callander, Perthshire belongs to the Dalradian Supergroup, and a reassessment of the 'exotic' status of the Highland Border Complex". Geological Magazine, 134, 563-70.

Bluck B.J., Ingham J.K., Curry G.B., and Williams A. (1984) The significance of a reliable age from some Highland Border rocks in Central scotland. Journal of the Geological Society of London 139, $451-4$.

Boersma, J.R. (1969) Internal structures of some tidal megaripples on a shoal in the Westerschelde estuary, the Netherlands. Geologie on Mijnbouw, 48, 409-14.

Booth, J.E. (1984) Structural, stratigraphic and metamorphic studies in the SE Dalradian Highlands. Unpublished PhD thesis. University of Edinburgh.

Borradaile, G.J. (1970) The west limb of the Loch Awe syncline and the associated cleavage fan. Geological Magazine, 107, 459-467.

Borradaile, G.J. (1972a) The structural and stratigraphic history of the Dalradian rocks of the Northern Loch Awe syncline, Argyllshire. Unpublished PhD thesis, University of Liverpool.

Borradaile, G.J. (1972b) Variably oriented co-planar primary folds. Geological Magazine, 190, 89-98. 
Borradaile, G. J. (1973) Dalradian structure and stratigraphy of the northern Loch Awe district, Argyllshire. Transactions of the Royal Society of Edinburgh, 69, 1-21.

Borradaile, G.J. (1974). Bulk finite strain estimates from the deformation of Neptunian dykes. Tectonophysics, 22, 127-39.

Borradaile, G.J. (1977) The Dalradian rocks of the northern Loch Awe district. Scottish Journal of Geology, 13, 155-64.

Borradaile, G.J. (1979). Pre-tectonic reconstruction of the Islay anticline: implications for the depositional history of Dalradian rocks in the SW Highlands. In The Caledonides of the British Isles-reviewed. Harris, A L, Holland, C H, and Leake, B E (editors). Special Publication of the Geological Society of London, No. 8, pp. 229-38.

Borradaile, G.J. and Johnson, H.D. (1973) Finite strain estimates from the Dalradian Dolomitic Formation, Islay, Argyll, Scotland. Tectonophysics, 18, 249-59.

Boué, A. (1820) Essai Géologique sur l'Écosse. Ve Courcier, Paris.

Bouma, A. H. (1962). Sedimentology of some Flysch Deposits, a Graphic Approach to Facies Interpretation. Elsevier Co. Amsterdam, $168 \mathrm{pp}$.

Bowden, A.J. (2007) Book review: MacCulloch's 1840 Geological Map of Scotland. Scottish Journal of Geology, 43, 181-4.

Bowes, D.R. and Convery, H.J.E. (1966) The composition of some Ben Ledi grits and its bearing on the origin of albite schists in the south-west Highlands. Scottish Journal of Geology, 2, 67-75.

Bowes, D.R. and Wright, A.E. (1967) The explosion breccia pipes near Kentallen, Scotland and their geological setting. Transactions of the Royal Society of Edinburgh, 67, 109-43.

Bowes, D.R. and Wright, A.E. (1973) Early phases of Caledonian deformation in the Dalradian of the Ballachulish district, Argyll. Geological Journal, 8, 333-44.

Bowring, S., Myrow, P., Landing, E., Ramezani, J. and Grotzinger, J. (2003) Geochronological constraints on Terminal Neoproterozoic events and the rise of metazoans. Geophysical Research Abstracts 5, p13219.

Bradbury, H.J. (1978) Stratigraphic, structural, igneous and metamorphic history of the Dalradian rocks of the Ben Vrackie-Ben Vuirich district, Tayside, Scotland. Unpublished PhD thesis, University of Liverpool.

Bradbury, H.J. (1979) Migmatization, deformation and porphyroblast growth in the Dalradian of Tayside, Scotland. In The Caledonides of the British Isles - Reviewed Harris, A.L., Holland, C.H. and Leake, B.E. (eds). Geological Society, London, Special Publications, 8 , 351-6.

Bradbury, H.J. (1985) The Caledonian metamorphic core: an Alpine model. Journal of the Geological Society of London, 142, 129-36.

Bradbury, H.J., and Harris, A.L. (1982) Low grade Dalradian sediments carrying spaced cleavage; Polyphase deformation of spaced cleavage. In Atlas of deformational and metamorphic rock fabrics. Borradaile, G J, Bayly, M B, and Powell, C McA (editors). Springer Verlag, Berlin, pp. 100-9.

Bradbury, H.J., Harris, A.L. and Smith, R.A. (1979). Geometry and emplacement of nappes in the Central Scottish Highlands. In The Caledonides of the British Isles - reviewed. (eds. Harris, A.L., Holland, C.H. and Leake, B.E.), Special Publication of the Geological Society of London, 8, 213-20. 
Bradbury H.J., Smith R.A. and Harris A.L. (1976) 'Older' granites as time-markers in Dalradian evolution. Journal of the Geological Society, London, 132, 677-84.

Brasier, M.D., Ingham, J.K. and Rushton, A.W.A. (1992) Cambrian. 13-18 in Atlas of Palaeogeography and Lithofacies. Cope, J.C.W., Ingham, J.K. and Rawson, P. F. (editors). Memoirs of the Geological Society, London, 13.

Brasier, M.D. and Mcilroy, D. (1998) Neonereites uniserialis from c. $600 \mathrm{Ma}$ year old rocks in western Scotland and the emergence of animals. Journal of the Geological Society, London, 155, 5-12.

Brasier, M.D. and Shields, G. (2000) Neoproterozoic chemostratigraphy and correlation of the Port Askaig glaciation, Dalradian Supergroup of Scotland. Journal of the Geological Society, London, 157, 909-14.

Brasier, M.D., McCarron, G., Tucker, R., Leather, J., Allen, P. and Shields, G. (2000) New U-Pb zircon dates for the Neoproterozoic Ghubrah glacaiation and for the top of the Huqf Supergroup, Oman. Geology, 28, 175-8.

Briden, J.C., Turnell, H.B. and Watts, D.R. (1984) British palaeomagnetism, Iapetus Ocean and the Great Glen Fault. Geology $12,136-9$.

Burgess J.G, Graham, C.M. and Harte, B. (1981). Kyanite and chloritoid phyllites from the chlorite zone of the Scottish Highlands. Journal of the Geological Society of London, 138, $p$. 634 (abstract).

Burt, C.E. (2002) Sedimentary environments and basin evolution of the upper Dalradian: Tayvallich Subgroup and Southern Highland Group. Unpublished PhD thesis, Kingston University.

Burton, C.J., Hocken, C., MacCallum, D. and Young, M.E. 1983. Chitinozoa and the age of the Margie Limestone of the North Esk. Proceedings of the Geological Society of Glasgow Vol. 124-125, 2732 .

Cannat M. (1989) Late Caledonian northeastward ophiolite thrusting in the Shetland Islands, U.K. Tectonophysics 169, 257-70.

Canning J.C., Henney P.J., Morrison M.A. and Gaskarth J.W. (1996) Geochemistry of late Caledonian minettes from northern Britain: implications for the Caledonian sub-continental lithospheric mantle. Mineralogical Magazine 60, 221-36.

Canning, J.C., Henney, P.J., Morrison, M.A., Van Calsteren, P.W.C., Gaskarth, J.W. and Swarbrick, A. (1998) The Great Glen Fault: a major vertical lithospheric boundary. Journal of the Geological Society, London, 155, 425-8.

Carty, J.P. (2001) Deformation, metamorphism, magmatism and fluidflow in the Portsoy Shear Zone, N.E. Scotland. Unpublished PhD thesis, University of Derby.

Cawood, P.A., McCausland, P.J.A. and Dunning, G.R. (2001) Opening Iapetus: constraints from the Laurentian margin in Newfoundland. Geological Society of America Bulletin, 113, 443-53.

Cawood, P.A., Nemchin, A.A., Smith, M. and Loewy, S. (2003). Source of the Dalradian Supergroup constrained by U-Pb dating of detrital zircon and implications for the East Laurentian margin. Journal of the Geological Society of London 160, 231-46.

Cawood, P.A., Nemchin, A.A., Strachan, R.A., Prave, A.R. and Krabbendam, M. (2007) Sedimentary basin and detrital zircon record along East Laurentia and Baltica during assembly and breakup of Rodinia. Journal of the Geological Society, London, 164, 257-75. 
Chew, D.M. (2001) Basement protrusion origin of serpentinite in the Dalradian. Irish Journal of Earth Science, 19, 23-35.

Chew, D.M., Daly, J.S., Magna, T., Page, L.M., Kirkland, C.L., Whitehouse, M.J. and Lam, R. (2010) Timing of ophiolite obduction in the Grampian orogen. Geological Society of America Bulletin, $122,1787-1799$.

Chew, D.M., Fallon, N., Kennelly, C., Crowley, Q. and Pointon, (2009) Basic volcanism contemporaneous with the Sturtian glacial episode in NE Scotland. Earth and Environmental Science Transactions of the Royal Society of Edinburgh, 100, 399-415

Chew, D.M., Graham, J.R. and Whitehouse, M.J. (2007) U-Pb zircon geochronology of plagiogranites from the Lough Nafooey (= Midland Valley) arc in western Ireland: constraints on the onset of the Grampian orogeny. Journal of the Geological Society, London Vol. $164,747-50$.

Chinner, G.A. (1957) The metamorphic history of the Glen Clova district, Angus. Unpublished PhD Thesis, University of Cambridge.

Chinner, G.A. (1960) Pelitic gneisses with varying ferrous/ferric ratios from Glen Clova, Angus, Scotland. Journal of Petrology, 1, $178-217$.

Chinner, G.A. (1961) The origin of sillimanite in Glen Clova, Angus. Journal of Petrology Vol. 2, 312-23.

Chinner, G.A. (1966) The distribution of pressure and temperature during Dalradian metamorphism. Quarterly Journal of the Geological Society of London, 122, 159-86.

Chinner, G.A. (1978) Metamorphic zones and fault displacement in the Scottish Highlands. Geological Magazine, Vol. 115, 37-45.

Chinner, G.A. and Heseltine, F.J. (1979) The Grampian andalusite/kyanite isograd. Scottish Journal of Geology, Vol. 15, $117-127$.

Coats, J.S., Pease, S.F. and Gallagher, M.J. (1984) Exploration of the Scottish Dalradian. 21-34 in Prospecting in areas of glaciated terrain. (London: Institution of Mining and Metallurgy.)

Coats, J.S., Smith, C.G., Gallagher, M.J., May, F., Fortey, N.J. and Parker, M.E. (1978) Stratabound barium-zinc mineralisation in Dalradian schist near Aberfeldy, Scotland: preliminary report. Institute of Geological Sciences, Mineral Reconnaisance Programme Report No. 26.

Coats, J.S., Smith, C.G., Fortey, N.J., Gallagher, M.J., May, F. and McCourt, W.J. (1980) Stratabound barium-zinc mineralization in Dalradian schist near Aberfeldy. Transactions of the Institution of Mining and Metallurgy (Section B: Applied Earth Science), 89, $110-22$.

Coats, J.S., Smith, C.G., Gallagher, M.J., May, F., McCourt, W.J., Parker, M.E. and Fortey, N.J. (1981) Stratabound barium-zinc mineralisation in Dalradian schist near Aberfeldy, Scotland: final report. Institute of Geological Sciences, Mineral Reconnaissance Programme Report No. 40.

Collerson, K.D., Jesseau, C.W. and Bridgewater, D. (1976). Contrasting types of bladed olivine in ultramafic rocks from the Archaean of Labrador. Canadian Journal of Earth Sciences, 13, 44250 .

Collinson, J. (1994). Sedimentary deformational structures. pp. 95125 In Maltman, A. (ed.). The geological deformation of sediments. Chapman and Hall.

Collinson, J.D. and Thompson, D.B. 1988. Sedimentary Structures. George Allen and Unwin, London. 207 pp. 
Condon, D.J. and Prave, A.R. (2000). Two from Donegal: Neoproterozoic glacial episodes on the northeast margin of Laurentia. Geology, 28, 951-4.

Cooper, M.R. and Johnston, T.P. (2004) Central Highlands (Grampian) Terrane. 9-24, in: Mitchell, W.I. (editor), The Geology of Northern Ireland-Our Natural Foundation (2nd edition). Geological Survey of Northern Ireland, Belfast.

Coward, M.P. (1983) The thrust and shear zones of the Moine Thrust Zone of NW Scotland. Journal of the Geological Society of London $140,795-811$.

Coward, M.P. (1990) The Precambrian, Caledonian and Variscan framework to NW Europe. In Tectonic Events Responsible for Britain's Oil and Gas Reserves. Hardman, R.F.P. and Brooks, J. (eds) Geological Society, London, Special Publications, 55, 1-34.

Craig G. Y., MCIntyre D. B., and Waterston C. D. (1978) James Hutton's Theory of the Earth: the lost drawings. Scottish Academic Press, Edinburgh.

Crane A., Goodman S., Krabbendam M., Leslie A. G., Paterson I. B., Robertson S. And Rollin K. E. (2002) Geology of the Glen Shee District. Memoir of the British Geological Survey. Sheet 56W with parts of sheets 55E, 65W and 64E (Scotland).

Cummins, W.A. and Shackleton, R.M. (1955) The Ben Lui recumbent syncline. Geological Magazine, 92, 353-62.

Cunningham Craig, E.H. (1904) Metamorphism in the Loch-Lomond District. Quarterly Journal of the Geological Society, London, 60, $10-31$.

Cunningham Craig, E.H. (2000) (written 1901). Explanation of Sheet 38 (Loch Lomond). Selected documents from the BGS Archives No 3. British Geological Survey Technical Report No. wo/00/05.

Cunningham Craig, E.H., Wright, W.B. and Bailey, E.B. (1911) The Geology of Colonsay and Oronsay with parts of Ross of Mull. Memoir of the Geological Survey of Scotland, Sheet 35 (Scotland).

Curry, G.B., Bluck, B.J., Burton, C.J., Ingham, J.K., Siveter, D.J. And Williams, A. (1984) Age, evolution and tectonic history of the Highland Border Complex, Scotland. Transactions of the Royal Society of Edinburgh: Earth Sciences, 75, 113-33.

Cutts, K.A., Hand, M., Kelsey, D.E. and Strachan, R.A. (2011) P-T constraints and timing of Barrovian metamorphism in the shetland Islands, Scottish Caledonides: implications for the structural setting of the Unst ophiolite. Journal of the Geological Society, $168,1265-1284$.

Dallmeyer, R.D., Strachan, R.A., Rogers, G., Watt, G.R. and Friend, C.R.L. (2001) Dating deformation and cooling in the Caledonian thrust nappes of north sutherland, Scotland: insights from 40Ar/39Ar and Rb-Sr chronology. Journal of the Geological society of London 158, 501-12.

Daly, J.S., Muir, R.J. and Cliff, R.A. (1991) A precise U-Pb zircon age for the Inishtrahull syenitic gneiss, County Donegal, Ireland. Journal of the Geological Society, London, 148, 639-42.

Dalziel, I.W.D. (1994) Precambrian Scotland as a Laurentia-Gondwana link: Origin and significance of cratonic promontories. Geology, $22,589-92$.

Dalziel, I.W.D. (1997) Neoproterozoic-Paleozoic geography and tectonics; review, hypothesis, environmental speculation. Geological Society of America Bulletin 109(1), 16-42. 
Davidek, K., Landing, E., Bowring, S.A., Westrop, S.R., Rushton, S.A., Fortey, R.A. And Adrain, J. (1998) New Uppermost Cambrian U$\mathrm{Pb}$ date from Avalonian Wales and age of the Cambrian-Ordovician boundary. Geological Magazine, 135, 303-09.

Deer, W.A., Howie, R.A. and Zussman, J. (1992). An Introduction to the Rock Forming Minerals, 2nd ed. Longman Scientific and Technical, London.

Dempster, T.J. (1983) Studies of orogenic evolution in the Scottish Dalradian. Unpublished PhD thesis, University of Edinburgh.

Dempster, T.J. (1985a) Uplift patterns and orogenic evolution in the Scottish Dalradian. Journal of the Geological Society of London, 142, 111-128.

Dempster, T.J. (1985b) Garnet zoning and metamorphism of the Barrovian type. Contributions to Mineralogy and Petrology, 89, 308.

Dempster T.J. and Bluck B.J. (1991) The age and tectonic significance of the Bute amphibolite, Highland Border Complex, Scotland. Geological Magazine 128, 77-80.

Dempster, T.J. and Harte, B. (1986) Polymetamorphism in the Dalradian of the Central Scottish Highlands. Geological Magazine, Vol. 123, 95-104.

Dempster, T.J., Hudson, N.F. and Rogers, G. (1995). Metamorphism and cooling of the NE Dalradian. Journal of the Geological Society, London, 152, 383-90.

Dempster, T.J., Rogers, G., Tanner, P.W.G., Bluck, B.J., Muir, R.J., Redwood, S.D., Ireland, T.R. and Paterson, B.A. (2002) Timing of deposition, orogenesis and glaciation within the Dalradian rocks of Scotland: constraints from U-Pb zircon ages. Journal of the Geological Society, London, 159, 83-94.

Dewey, H. and Flett, J.S. (1911) On some British pillow lavas and the rocks associated with them. Geological Magazine, 8, 202-9, 240-8.

Dewey J. F. (1969) Evolution of the Appalchian/Caledonian orogen. Nature, London 222, $124-9$.

Dewey, J.F. (2005) Orogeny can be very short. Proceedings of the National Academy of Sciences, USA Vol. 102, 15286-93.

Dewey, J.F. and Mange, M. (1999) Petrography of Ordovician and Silurian sediments in the western Irish Caledonides: tracers of a short-lived Ordovician continent-arc collision orogeny and the evolution of the Laurentian Appalachian-Caledonian margin. In: Continental Tectonics (edited by MacNiocaill, C. and Ryan, P. D.). Geological Society, London, Special Publication, 164, 55-107.

Dewey, J.F. and Pankhurst, R.J. (1970) The evolution of the Scottish Caledonides in relation to their radiometric age pattern. Transactions of the Royal Society of Edinburgh, 68, 361-89.

Dewey, J.F. and Ryan, P.D. (1990) The Ordovician evolution of the South Mayo Trough, Western Ireland. Tectonics, 9, 887-903.

Dewey J.F. and Shackleton R.M. (1984) A model for the evolution of the Grampian tract in the early Caledonides and Appalachians. Nature, London 312, 115-21.

Dewey, J.F. and Strachan, R.A. (2003) Changing Silurian-Devonian relative plate motion in the Caledonides; sinistral transpression to sinistral transtension. Journal of the Geological society, London, 160, 219-229.

Dickin, A.P. (1992). Evidence for an Early Proterozoic crustal province in the North Atlantic region. Journal of the Geological Society, London, 149, 483-6. 
Dickin, A.P., and Bowes, D.R. (1991) Isotopic evidence for the extent of the early Proterozoic basement of Scotland and northwest Ireland. Geological Magazine, 128, 385-8.

Droop, G.T.R. (1987). A general equation for estimating $\mathrm{Fe}^{3+}$ concentrations in ferromagnesian silicates or oxides from microprobe analysis using stoichiometric criteria. Mineralogical Magazine, 51, 431-55.

Droop G.T.R. and Charnley N. (1985) Comparative geobarometry of pelitic hornfelses associated with the Newer Gabbros: a preliminary study. Journal of the Geological Society of London $142,53-62$.

Droop, G.T.R., Clemens, J.D. and Dalrymple, D.J. (2003) Processes and conditions during contact anatexis, melt escape and restite formation: the Huntley Gabbro complex, NE Scotland. Journal of Petrology Vol. 44, 995-1029.

Donovan, R.N. and Foster, R.J. (1972). Subaqueous shrinkage cracks from the Caithness Flagstone Series (Middle Devonian) of northeast Scotland. Journal of Sedimentary Petrology, 42, 309-17.

Downie, C. (1975) The Precambrian of the British Isles: Palaeontology. In A Correlation of Precambrian Rocks in the British Isles (eds. Harris, A.L., Shackleton, R.M., Watson, J.V., Downie, C., Harland, W.B. and Moorbath, S.). Special Report of the Geological Society of London, No. 6. Pp. 113-15

Downie, C. (1984) Acritarchs in British stratigraphy. Special Report of the Geological Society of London, No. 17.

Downie, C., Lister, T.R., Harris, A.L. and Fettes, D.J. (1971) A palynological investigation of the Dalradian rocks of Scotland. Report of the Institute of Geological Sciences, No. $71 / 9$.

Dymoke, P.L. (1989) Geochronological and petrological studies of the thermal evolution of the Dalradian, South-west Scottish Highlands. Unpublished PhD thesis, University of Edinburgh.

Eby G. N. (1992) Chemical subdivision of the A-type granitoids: petrogenetic and tectonic implications. Geology, 20, 641-4.

Edwards, M.B. (1986) Glacial Environments. 416-436 in: Sedimentary Environments and facies (Editor: H.G. Reading). Blackwell Scientific

Publications.

Elles, G.L. (1926) The geological structure of Ben Lawers and Meall Corranaich (Perthshire). Quarterly Journal of the Geological Society of London, 82, 304-31.

Elles, G.L. (1931) Notes on the Portsoy coastal district. Geological Magazine, 68, 24-34.

Elles, G.L. (1935) The Loch na Cille Boulder Bed and its place in the Highland succession. Quarterly Journal of the Geological Society of London, 91, 111-49.

Elles, G.L. and Tilley, C.E. (1930) Metamorphism in relation to structure in the Scottish Highlands. Transactions of the Royal Society of Edinburgh, 56, 621-46.

Ellis, D.J. and Green, D.H. (1979) An experimental study of the effect of Ca upon garnet-clinopyroxene Fe-Mg exchange equilibria. Contributions to Mineralogy and Petrology, 71, 13-22.

Ellis, N.V., Bowen, D.Q., Campbell, S., Knill, J.L., McKirdy, A.P., Prosser, C.D., Vincent, M.A. and Wilson, R.C.L. (1996) An Introduction to the Geological Conservation Review. Joint Nature Conservation Committee, Peterborough. 
Emery, M. (2005) Polyorogenic history of the Moine rocks of Glen Urquhart, Inverness-shire. Unpublished PhD thesis, University of Portsmouth.

Evans, J.A., Fitches, W.R. and Muir, R.J. (1998) Laurentian Clasts in a Neoproterozic Tillite in Scotland. Journal of Geology, 106, $361-9$.

Evans, J.A, and Soper, N.J. (1997) Discussion on metamorphism and cooling of the NE Dalradian and $\mathrm{U}-\mathrm{Pb}$ and $\mathrm{Rb}-\mathrm{Sr}$ geochronology of magmatism and metamorphism in the Dalradian of Connemara, western Ireland. Journal of the Geological Society, London, 154, 357-60.

Evans, R.H.S. and Tanner, P.W.G. (1996). A late Vendian age for the Kinlochlaggan Boulder Bed (Dalradian)? Journal of the Geological Society, London, 153, 823-6.

Evans, R.H.S. and Tanner, P.W.G. (1997). Discussion on a late Vendian age for the Kinlochlaggan Boulder Bed (Dalradian): reply. Journal of the Geological Society, London, 154, 917-19.

Eyles, C.H. (1988) Glacially - and tidally - influenced shallow marine sedimentation of the Late Precambrian Port Askaig Formation, Scotland. Palaeogeography, Palaeoclimatology, Palaeoecology, 68, 1-25.

Eyles, C.H. and Eyles, N. (1983) Glaciomarine model for upper Precambrian diamictiles of the Port Askaig Formation, Scotland. Geology, 11, 692-6.

Eyles, N. and Clark, M. (1985) Gravity-induced soft-sediment deformation in glaciomarine sequences of the upper Proterozoic Port Askaig Formation, Scotland. Sedimentology, 32, 789-814.

Fairchild, I.J. (1977) Phengite spherules from the Dalradian Bonnahaven Formation, Islay, Scotland: Glauconitized microfossils. Geological Magazine, 114, 355-64.

Fairchild, I.F. (1980a) Sedimentation and origin of a Late Precambrian "dolomite" from Scotland. Journal of Sedimentary Petrology, 50, 423-46.

Fairchild, I.J. (1980b) Stages in a Precambrian dolomitization, Scotland: Cementing versus replacement textures. Sedimentology, $27,631-50$.

Fairchild, I.J. (1980c) The structure of NE Islay. Scottish Journal of Geology, 16, 189-97.

Fairchild, I.J. (1985) Comment on 'Glaciomarine model for Upper Precambrian diamictiles of the Port Askaig Formation, Scotland'. Geology, 13, 89-90.

Fairchild, I.J. (1985) Petrography and carbonate chemistry of some Dalradian dolomitic metasediments: preservation of diagenetic textures. Journal of the Geological Society, London, 142, 167-85.

Fairchild, I.J. (1989) Dolomitic stromatolite-bearing units with storm deposits from the Vendian of East Greenland and Scotland: a case of facies equivalence. In Caledonian and related Geology of Scandinavia (ed. Gayer, R. A.), pp. Graham and Trotman, London, pp. 275-283.

Fairchild, I.J. (1991) Itinerary II: Topmost Islay Limestone (Appin Group), Port Askaig and Bonahaven Formations (Argyll Group) Port Askaig area, Islay. In The Late Precambrian geology of the Scottish Highlands and Islands (ed. Lister, C.J.) Geologists' Association Guide No. 44, pp. 33-41.

Fairchild, I.J. (1993) Balmy shores and icy wastes: the paradox of carbonates associated with glacial deposits in Neoproterozoic times. Sedimentology Review, 1, 1-16. 
Ferry, J.M. and Spear, F.S. (1978) Experimental calibration of the partitioning of $\mathrm{Fe}$ and $\mathrm{Mg}$ between biotite and garnet. Contributions to Mineralogy and Petrology, 66, 113-17.

Fettes, D.J., (1968). Metamorphic structures of Dalradian rocks in North East Scotland. Unpublished PhD thesis, University of Edinburgh.

Fettes, D.J. (1970) The structural and metamorphic state of the Dalradian rocks and their bearing on the age of emplacement of the basic sheet. Scottish Journal of Geology, Vol. 6, 108-118.

Fettes, D.J. (1971) Relation of cleavage and metamorphism in the Macduff Slates. Scottish Journal of Geology, 7, 248-53.

Fettes, D.J. (1979) A metamorphic map of the British and Irish Caledonides. In: Harris, A.L., Holland, C.H. and Leake, B.E. (eds) The Caledonides of the British Isles-Reviewed. Geological Society, London, Special Publications, 8, 307-21.

Fettes, D.J. and Desmons, J. (editors) (2007) Metamorphic Rocks: a Classification and Glossary of Terms. Recommendations of the International Union of Geological Sciences Subcommission on the Systematics of Metamorphic Rocks. Cambridge University Press, Cambridge

Fettes, D.J., Graham, C.M., Harte, B., and Plant, J.A. (1986a) Lineaments and basement domains; an alternative view of Dalradian evolution. Journal of the Geological Society of London, 143, 453-64.

Fettes, D.J., Graham, C.M., Sassi, F.P., and Scolari, A. (1976) The lateral spacing of potassic white micas and facies series variations across the Caledonides. Scottish Journal of Geology, $12,227-36$.

Fettes, D.J., Harris, A.L. and Hall, L.M. (1986b) The Caledonian geology of the Scottish Highlands. In Synthesis of the Caledonian rocks of Britain. Proceedings of the NATO Advanced Study Institute. Fettes, D J, and Harris, A L (editors). Reidel Dordrecht, pp. 303-34.

Fettes, D.J., Leslie A.G., Stephenson D., and Kimbell S.F. (1991) Disruption of Dalradian stratigraphy along the Portsoy Lineament from new geological and magnetic surveys. Scottish Journal of Geology 27, 57-73.

Fettes, D.J., Long, C.B., Bevins, R.E., Max, M.D., Oliver, G.J.H., Primmer, T.J., Thomas, L.J. and Yardley, B.W.D., 1985. Grade and time of metamorphism in the Caledonide Orogen of Britain and Ireland. . 5 In, Harris, A.L.(ed), The Nature and Timing of Orogenic Activity in the Caledonian Rocks of the British Isles. Memoir of the Geological Society, London, 9.

Fettes, D.J., Macdonald, R., Fitton, J.G., Stephenson, D. and Cooper, M.R. (2011) Geochemical evolution of Dalradian metavolcanic rocks: implications for the break-up of the Rodinia supercontinent. Journal of the Geological Society, 168, 1133-1146.

Fisk, S. (1986) An oxygen isotope study of siliceous rocks associated with stratabound mineralisation in Scotland and Ireland. Unpublished PhD thesis, University of Strathclyde.

Fitches, W. R. And Maltman, A. J. (1984) Tectonic development and stratigraphy of the western margin of the Caledonides: Islay and Colonsay, Scotland. Transactions of the Royal Society of Edinburgh, 75, 365-82.

Fitches, W.R., Muir, R.J., Maltman, A.J. and Bentley, M.R. (1990) Is the Colonsay-west Islay block of SW Scotland an allochthonous 
terrane? Evidence from Dalradian tillite clasts. Journal of the Geological Society, London, 147, 417-20.

Fitches, W.R., Pearce, J.A., Evans, J.A. and Muir, R.J. (1996) Provenance of the late Proterozoic Dalradian tillite clasts, Inner Hebrides, Scotland. In Precambrian Crustal Evolution in the North Atlantic Region (ed. Brewer, T. S.), pp. 367-77.

Flinn, D., (1953) Regional metamorphism and migmatisation in Delting, Shetland. Unpublished PhD thesis, University of London, Imperial College.

Flinn, D. (1954) On the time relations between regional metamorphism amd permeation in Delting, Shetland. Quarterly Journal of the Geological Society of London, 110, 177-99.

Flinn, D. (1961) Continuation of the Great Glen Fault beyond the Moray Firth. Nature, London, 191, 589-91.

Flinn, D. (1967) The metamorphic rocks of the southern part of the Mainland of Shetland. Geological Journal, 5, 251-90.

Flinn, D. (1985) The Caledonides of Shetland. In Gee, D. G. and Sturt, B. A. (editors) The Caledonide Orogen-Scandinavia and Related Areas. John Wiley and Sons, Chichester. 1161-72.

Flinn, D. (1995) Formation of gneisses of migmatite and diatexite appearance in Yell, shetland by solid-state grain growth recrystallisation. Geological Journal, 30, 415-22.

Flinn, D. (1999) The Shetland Ophiolite. 31-33, 36-58 In Stephenson et al. (editors) Caledonian Igneous Rocks of Great Britain. Geological Conservation Review Series, No. 17. Joint Nature Conservation Committee, Peterborough, UK.

Flinn, D. (2001) The basic rocks of the Shetland Ophiolite Complex and their bearing on its genesis. Scottish Journal of Geology, 37 , $79-96$.

Flinn, D. (2007) The Dalradian rocks of Shetland and their implications for the plate tectonics of the northern Iapetus. Scottish Journal of Geology, Vol. 43, 125-42.

Flinn, D. in press. Geology of Unst and Fetlar in shetland. Memoir of the British Geological Survey, Sheet 131 (Scotland).

Flinn, D. and Moffat, D. T. 1985. A peridotitic komatiite from the Dalradian of Shetland. Geological Journal, 20, 287-292.

Flinn, D. and Moffat, D.T. (1986) A reply to R. W. Nesbitt and L. A. Hartmann. Geological Journal, 21, 207-9.

Flinn, D. and Pringle, I.R. (1976). Age of migmatisation in the Dalradian of Shetland. Nature, London, 259, 299-300.

Flinn, D., Frank, P.L., Brook, M. and Pringle, I.R. (1979) Basement-cover relations in shetland. In the Caledonides of the British Isles-reviewed. Harris, A.L., Holland, C.H. and Leake, B.E. (eds), Geological Society of London Special Publication No. $8,109-15$.

Flinn, D., May, F., Roberts, J.L. and Treagus, J.E. (1972). A revision of the stratigraphic succession of the East Mainland of Shetland. Scottish Journal of Geology, 8, 335-343.

Flinn, D., Miller, J.A. and Roddam, D. (1991) The age of the Norwick hornblendic schists of Unst and Fetlar and the obduction of the Shetland ophiolite. Scottish Journal of Geology 27, 11-19.

Flinn, D. and Oglethorpe, R.J.D. (2005). A history of the Shetland ophiolite Complex. Scottish Journal of Geology, 41, 141-8.

Fortey, N.J., Coats, J.S., Gallagher, M.J., Greenwood, P.G. and Smith, C.G. (1993) Dalradian stratabound baryte and base metals near Braemar, NE Scotland. Transactions of the Institution of 
Mining and Metallurgy (Section B: Applied Earth Science), Vol. 102, B55-64.

Fortey, N.J. and Smith, C.G. (1986). Stratabound mineralisation in Dalradian rocks near Tyndrum, Perthshire. Scottish Journal of Geology, 22, 377-93.

France, D.S. (1971) Structure and metamorphism of Moine and Dalradian rocks in the Grampians of Scotland near Beinn Dorain between Tyndrum and Moor of Rannoch. Unpublished PhD thesis, University of Liverpool.

Francis, E.H. (1982). Magma and sediment-1: Emplacement mechanisms of late Carboniferous tholeitic sills in Northern Britain. Journal of the Geological Society, London, 139, 1-20.

Friedrich, A.M, Hodges, K.V., Bowring, S.A. and Martin, M.W. (1999) Geochronological constraints on the magmatic, metamorphic and thermal evolution of the Connemara Caledonides, western Ireland. Journal of the Geological Society, London, 156, 1217-30.

Friend, C.R.L., Kinny, P.D., Rogers, G., Strachan, R.A. and Patterson, B.A. (1997) U-Pb zircon geochronological evidence for Neoproterozoic events in the Glenfinnan Group (Moine Supergroup): the formation of the Ardgour granite gneiss, north-west Scotland. Contributions to Mineralogy and Petrology 128, 101-13.

Friend, C.R.L., Strachan, R.A., Kinny, P.D. and Watt, G.R. (2003) Provenance of the Moine Supergroup of NW Scotland; evidence from geochronology of detrital and inherited zircons from (meta)sedimentary rocks, granites and migmatites. Journal of the Geological Society, London 160, 247-57.

Gallagher, M.J., Smith, C.G., Coats, J.S., Greenwood, P.G., Chacksfield, B.C., Fortey, N.J. and Nancarrow, P.H.A. (1989) Stratabound barium and base-metal mineralisation in Middle Dalradian metasediments near Braemar, Scotland. British Geological Survey, Mineral Reconnaisance Programme Report, No. 104.

Ganguly, J. (1979) Garnet and clinopyroxene solid solutions, and geothermometry based on Fe-Mg distribution coefficient. Geochemica and Cosmochemica Acta 43, 1021-9.

Garson, M.S, and Plant, J. (1973) Alpine Type Ultramafic Rocks and Episodic Mountain Building in the Scottish Highlands. Nature Physical Science, 242, 34-8.

Geikie, A. (1865) The scenery of Scotland viewed in connection with its physical geology (with a geological map by Sir Roderick I. Murchison and Archibald Geikie). Macmillan, London and Cambridge.

Geikie, A. (1897) Annual report of the Geological Survey of the United Kingdom and of the Museum of Practical Geology for the year ending December 31, 1896. In Appendix E from the 44th Report of the Department of Science and Art. (London: Her Majesty's Stationery Office.)

Gibbons, W. And Harris, A.L. (1994) A Revised Correlation of Precambrian rocks in the British Isles. Special Reports, Geological Society, London, 22.

Gillen, C. (1987) Huntly, Elgin and Lossiemouth. 149-160 in Excursion Guide to the Geology of the Aberdeen area. (editors N.H.Trewin, B.C. Kneller, and C. Gillen,). (Edinburgh: Scottish Academic press for Geological Society of Aberdeen).

Gillespie, M.R. and Styles, M.T. (1999). BGS rock classification scheme, Volume 1: Classification of igneous rocks, 2nd edition. British Geological Survey Research Report, RR/99/6 
Glover, B.W. (1989). The sedimentology and basin evolution of the Grampian Group. Unpublished PhD Thesis. University of Keele.

Glover, B.W. (1993). The sedimentology of the Neoproterozoic Grampian Group and the significance of the Fort William Slide between Spean Bridge and Rubha Cuilcheanna, Inverness-shire. Scottish Journal of Geology, 29, 29-43.

Glover, B.W. (1998). Sedimentology and lateral extent of the Glenshirra succession, Monadhliath Mountains, Scotland. British Geological Survey Technical Report, WA/98/23.

Glover B.W., Key, R.M., May, F., Clark, G.C., Phillips, E.R. and Chacksfield, B.C. (1995). A Neoproterozoic multi-phase rift sequence: the Grampian and Appin groups of the southwestern Monadhliath Mountains of Scotland. Journal of the Geological Society of London, 152, 391-406.

Glover B.W. and MCKie, T. (1996). A sequence stratigraphical approach to the understanding of basin history in orogenic Neoproterozoic successions: an example from the central Highlands of Scotland. In: Sequence stratigraphy in British Geology (eds. Hesselbo, S.P. and Parkinson, D.N. ). Geological Society of London, Special Publication, 103, 257-69.

Glover, B.W. and Winchester, J.A. (1989) The Grampian Group: a major Late Proterozoic clastic sequence in the central Highlands of Scotland. Journal of the Geological Society, London, 146, 8597 .

Goodman, S (1991) The Pannanich Hill Complex and the origin of the Crinan Subgroup migmatites in the North-eastern and Central Highlands. Scottish Journal of Geology, 27, 147-56.

Goodman, S. (1994) The Portsoy-Duchray Hill Lineament; a review of the evidence. Geological Magazine 131, 407-15.

Goodman, S., Crane, A., Krabbendam, M. and Leslie, A.G. (1997) Correlation of lithostratigraphic sequences in a structurally complex area: Gleann Fearnach to Glen Shee, Scotland. Transactions of the Royal Society of Edinburgh, 87, 503-13.

Goodman, S, and Lappin, M.A. (1996) The thermal aureole of the Lochnagar Complex: mineral reactions and implications from thermal modelling. Scottish Journal of Geology, 27, 159-72.

Goodman, S., Leslie, A.G., Ashcroft, W.A. and Crane, A. (1990) The geology of the central part of Sheet 65E (Ballater); contribution to the memoir. British Geological Survey Technical Report No.

\section{WA/90/59.}

Goodman, S. and Winchester, J.A. (1993) Geochemical variations within metavolcanic rocks of the Dalradian Farragon Beds and adjacent formations. Scottish Journal of Geology, 29, 131-41.

Gorokhov, M., Siedlecka, A., Roberts, D., Melnikov, N.N. and Turchenko, T.L. (2001) Rb-Sr dating of diagenetic illite in Neoproterozoic shales, Varanger Peninsula, northern Norway. Geological Magazine, 138, 541-62.

Gould, D. (1997) The geology of the country around Inverurie and Alford. Memoir of the British Geological Survey, sheets 76E and 76W (Scotland).

Gould, D. (2001) Geology of the Aboyne district. Memoir of the British Geological Survey, Sheet 66W (Scotland).

Gower, P.J. (1973) The Middle-Upper Dalradian Boundary with special reference to the Loch Tay Limestone. Unpublished PhD thesis, University of Liverpool.

Gower, P.J. (1977) The Dalradian rocks of the west coast of the Tayvallich peninsula. Scottish Journal of Geology, 13, 125-33. 
Gradstein, F.M., Ogg, J.G., and Smith, A.G., Agterberg, F.P., Bleeker, W., Cooper, R.A., Davydov, V., Gibbard, P., Hinnov, L.A., House, M.R., Lourens, L., Luterbacher, H.P., McArthur, J., Melchin, M.J., Robb, L.J., Shergold, J., Villeneuve, M., Wardlaw, B.R., Ali, J., Brinkhuis, H., Hilgen, F.J., Hooker, J., Howarth, R.J., Knoll, A.H., Laskar, J., Monechi, S., Plumb, K.A., Powell, J., Raffi, I., Röhl, U., Sadler, P., Sanfilippo, A., Schmitz, B., Shackleton, N.J., Shields, G.A., Strauss, H., Van Dam, J., van Kolfschoten, T., Veizer, J., and Wilson, D. (2004) A Geologic Time Scale 2004. Cambridge University Press, 589 pp.

Graham, C.M. (1976) Petrochemistry and tectonic significance of Dalradian metabasaltic rocks of the SW Scottish Highlands. Journal of the Geological Society, London, 132, 61-84.

Graham, C.M. (1983). High-pressure greenschist to epidoteamphibolite facies metamorphism of the Dalradian rocks of the SW Scottish Highlands. Geological Society Newsletter, 12, No. 4, 19.

Graham, C.M. (1986) The role of the Cruachan Lineament during Dalradian evolution. Scottish Journal of Geology, 22, 257-70.

Graham, C.M. and Borradaile, G.J. (1984). The petrology and structure of Dalradian metabasic dykes of Jura: implications for Dalradian evolution. Scottish Journal of Geology, 20, 257-70. Same page range as previous ref?

Graham, C.M. and Bradbury, H.J. (1981) Cambrian and late Precambrian basaltic igneous activity in the Scottish Dalradian: a review. Geological Magazine, 118, 27-37.

Graham, C.M., Greig, K.M., Sheppard, S.M.F. and Turi, B. (1983) Genesis and mobility of the $\mathrm{H}_{2} \mathrm{O}-\mathrm{CO}_{2}$ fluid phase during regional greenschist and epidote amphibolite facies metamorphism: a petrological and stable isotope study in the Scottish Dalradian. Journal of the Geological Society, London, 140, 577-599.

Graham, C.M. and Harte, B. (1985) Conditions of Dalradian metamorphism. Journal of the Geological Society, London, 142, 1-3.

Grant Wilson, J.S. (1882) Explanation of Sheet 97. Northern Aberdeenshire, Eastern Banffshire. Memoir of the Geological Survey, Scotland.

Grant Wilson, J.S. (1886) Explanation of Sheet 87, North-east Aberdeenshire and detached portions of Banffshire. Memoir of the Geological Survey, Scotland.

Grant Wilson, J.S., and Hinxman, L.W. (1890) Geology of central Aberdeenshire. Memoir of the Geological Survey of Scotland, Sheet 76 (Scotland).

Green, J.F.N. (1924) The structure of the Bowmore-Portaskaig District of Islay. Quarterly Journal of the Geological Society, London, 80, $72-105$.

Green, J.F.N. (1931) The South-west Highland Sequence. Quarterly Journal of the Geological Society of London 87, 513-550.

Gregory, J.W. (1910) Work for Glasgow geologists-the problems of the South-western Highlands. Transactions of the Geological Society of Glasgow 14, 1-29.

Gregory, J.W. (1916) Pre-Cambrian of Scotland. Handbuch der Regionaler Geologie, III, Part I, 34-42.

Gregory, J.W. (1928) The geology of Loch Lomond. Transactions of the Geological Society of Glasgow 18, 301-23.

Gregory, J.W. (1929) The Pre-Cambrian or Pre-Palaeozoic of Scotland. 28-42 in Evans, J. W. and Stubblefield, C. J. (editors) Handbook of the geology of Great Britain. Murby. 
Gregory, J.W. (1930) The sequence in Islay and Jura. Transactions of the Geological Society of Glasgow Vol. 18, 420-441.

Gregory, J.W. (1931) Dalradian Geology: The Dalradian Rocks of Scotland and their Equivalents in other Countries. Methuen, London.

Greig, K.M., (1987) Metamorphosed carbonates and fluid behaviour in the Dalradian of S.W. Argyll, Scotland. Unpublished PhD thesis, University of Edinburgh

Grieve, A. (1996) Ruskin and Millais at Glenfinlas. The Burlington Magazine, 138, 228-234.

Gunn, A.G., Styles, M.T., Stephenson, D., Shaw, M.H. and Rollin, K. (1990) Platinum-group elements in ultramafic rocks of the Upper Deveron Valley, near Huntly, Aberdeenshire. Mineral Reconnaissance Programme Report, British Geological Survey, No. 115 .

Gunn, W., Clough, C.T. and Hill, J.B. (1897) The Geology of Cowal, including the part of Argyllshire between the clyde and Loch Fyne. Memoirs of the Geological Survey of Scotland, Sheets 29, 37 and 38 .

Hackman, B.D. and Knill, J.L. (1962) Calcareous algae from the Dalradian of Islay. Palaeontology, 5, 268-71.

Hall, A.J. (1993) Stratiform mineralisation in the Dalradian of Scotland. In Mineralisation in the British Isles. Pattrick, R.A.D., and Polya, D.A. (editors). Chapman and Hall, London, pp. 38-101.

Hall, J., Brewer, J.A., Matthews, D.H. and Warner, M. (1984) Crustal structure across the Caledonides from the WINCH seismic reflection profile: Influences on the evolution of the Midland Valley of Scotland. Transactions of the Royal Society of Edinburgh: Earth Sciences, 75, 97-109.

Halliday, A.N., Graham, C.M., Aftalion, M. and Dymoke, P. (1989) The depositional age of the Dalradian Supergroup: U-Pb and $\mathrm{Sm}-\mathrm{Nd}$ isotopic studies of the Tayvallich Volcanics, Scotland. Journal of the Geological Society, London, 146, 3-6.

Hambrey, M.J. (1983) Correlation of the Late Proterozoic tillites in the North Atlantic region and Europe. Geological Magazine, 120, 209-32.

Hambrey, M.J. and Harland, W.B. (editors). (1981) Earth's prePleistocene glacial record. Cambridge University Press, Cambridge.

Hambrey, M.J. and Harland, W.B. (1985) The Late Proterozoic glacial era. Palaeogeography, Palaeoclimatology and Palaeoecology, 51, 255-72.

Hambrey, M.J. and Waddams, P. (1981) Glaciogenic boulder-bearing deposits in the Upper Dalradian Macduff Slates, northeastern Scotland. In Earth's pre-Pleistocene glacial record. Hambrey, M.J. and Harland, W.B. (editors). Cambridge University Press, Cambridge, pp. 571-5.

Harkness, R. (1861) On the rocks of the portions of the Highlands of Scotland south of the Caledonian Canal; and on their equivalents in the north of Ireland. Quarterly Journal of the Geological Society of London 17, 256-71.

Harris, A.L. (1960) Dalradian geology of an area between Pitlochry and Blair Atholl. Unpublished PhD thesis, University of Wales, Aberystwyth. 
Harris, A.L. (1962) Dalradian geology of the Highland Border, near Callander. Bulletin of the Geological Survey of Great Britain, 19, $1-15$.

Harris, A.L. (1963). Structural investigations in the Dalradian rocks between Pitlochry and Blair Atholl. Transactions of the Edinburgh Geological Society, 19, 256-278.

Harris, A.L. (1969) The relationships of the Leny Limestone to the Dalradian. Scottish Journal of Geology, 5, 187-90.

Harris, A.L. (1972) The Dalradian rocks at Dunkeld, Perthshire. Bulletin of the Geological Survey of Great Britain, 38, 1-10.

Harris, A.L. (1995) Nature and timing of orogenesis in the Scottish Highlands and the role of the Great Glen Fault. In Current perspectives in the Appalachian-Caledonian Orogen, Hibbard, J., van Stall, C.R. and Cawood, P.A. (editors) Geological Association of Canada, Special Paper 41, 65-79.

Harris, A.L., Baldwin, C.T., Bradbury, H.J., Johnson, H.D. and Smith, R.A. (1978) Ensialic basin sedimentation: the Dalradian Supergroup. In Crustal evolution in northwestern Britain, Bowes, D R, and Leake, B E (editors) Special Issue of the Geological Journal No. 10 . Seel House Press, Liverpool, pp. 115-38

Harris, A.L., and Bradbury, H.J. (1977) Discussion of 'The evolution and transport of the Tay Nappe'. Scottish Journal of Geology, 13, 81-3.

Harris, A.L., Bradbury, H.J. and McGonigal, N.H. (1976) The evolution and transport of the Tay Nappe. Scottish Journal of Geology, 12, 103-13.

Harris, A.L. And Fettes, D.J. (1972) Stratigraphy and structure of Upper Dalradian rocks at the Highland Border. Scottish Journal of Geology, 8, 253-64.

Harris, A.L., Fettes, D.J. And Soper, N.J. (1998a) Age of the Grampian event: a Discussion of "New evidence that the Lower Cambrian Leny Limestone at Callander, Perthshire, belongs to the Dalradian Supergroup, and a re-assessment of the "exotic" status of the Highland Border Complex". Geological Magazine, 135, 575.

Harris, A.L., Haselock, P.J., Kennedy, M.J., Mendum, J.R., Long, J.A., Winchester, J.A. and Tanner, P.W.G. (1994). The Dalradian Supergroup in Scotland, Shetland, and Ireland, In A Revised Correlation of the Precambrian Rocks of the British Isles (eds. W. Gibbons and A.L. Harris), Geological Society, London, Special Report No. 22, 33-53.

Harris, A.L., Parson, L.M., Highton, A.J. and Smith, D.I. 1981. New/Old Moine relationships between Fort Augustus and Inverness (Abstract). Journal of Structural Geology, 3, 187-88.

Harris, A.L. and Pitcher, W.S. (1975) The Dalradian Supergroup. In A Correlation of Precambrian Rocks in the British Isles. (eds. Harris, A. L., Shackleton, R. M., Watson, J.V., Downie, C., Harland, W. B. and Moorbath, S.), Special Reports of the Geological Society, London, 6, pp. 52-75.

Harte, B. (1966) Stratigraphy, structure and metamorphism in the south-eastern Grampian Highlands of Scotland. Unpublished PhD thesis, University of Cambridge.

Harte, B., (1975) Determination of a pelite petrogenetic grid for the eastern Scottish Dalradian. Yearbook of the Carnegie Institute, Washington, 74, 438-446.

Harte, B. (1979) The Tarfside succession and the structure and stratigraphy of the eastern Scottish Dalradian rocks. In Special 
Publications, Geological Society, London, 8 (eds. Harris, A. L., Holland, C. H. and Leake, B. E.), pp. 221-28.

Harte, B. (1987) Glen Esk Dalradian, Barrovian metamorphic zones. In Excursion Guide to the Geology of the Aberdeen area. (editors N.H.Trewin, B.C. Kneller, and C. Gillen,). Scottish Academic press for Geological Society of Aberdeen, Edinburgh, p 193-210.

Harte, B. (1988) Lower Palaeozoic metamorphism in the MoineDalradian belt of the British Isles. In The CaledonianAppalachian Orogen. Harris, A L, and Fettes, D J (editors). Special Publication of the Geological Society of London, No. 38, pp. 123-34.

Harte, B., Booth, J.E., Dempster, T.J., Fettes, D.J., Mendum, J.R. and Watts, D. (1984) Aspects of the post-depositional evolution of Dalradian and Highland Border Complex rocks in the Southern Highlands of Scotland. Transactions of the Royal Society of Edinburgh, 75, 151-63.

Harte, B., Booth, J.E. and Fettes, D.J., (1987) Stonehaven to Findon: Dalradian Structure and Metamorphism. In Excursion Guide to the Geology of the Aberdeen Area (eds Trewin, N. H., Kneller, B. C. and Gillen, C.). Scottish Academic Press for Geological Society of Aberdeen, Edinburgh, pp. 211-26

Harte, B. and Dempster, T.J. (1987) Regional metamorphic zones: tectonic controls. Philosophical Transactions of the Royal society of London Vol. 321, 105-27.

Harte, B, and Hudson, N.F.C. (1979) Pelite facies series and the temperatures and pressures of Dalradian metamorphism in $E$ Scotland. in The Caledonides of the British Isles-Reviewed. (eds. A.L. Harris, C.H. Holland, and B.E. Leake,) Geological Society of London Special Publication, 8, pp 323-37.

Harte, B, and Johnson, M.R.W. (1969) Metamorphic history of Dalradian rocks in Glens Clova, Esk and Lethnot, Angus, Scotland. Scottish Journal of Geology, 5, 54-80.

Haselock, P.J. (1982) The geology of the Corrieyairack Pass area, Inverness-shire. Unpublished PhD thesis, University of Keele.

Haselock, P.J. (1984) The systematic geochemical variation between two tectonically separate successions in the southern Monadhliaths, Inverness-shire. Scottish Journal of Geology. 20, $191-205$.

Haselock, P.J. and Gibbons, W. (1990). The Central Highland controversy: a traverse through the Precambrian metasediments of the Central Highlands of Scotland. Episodes 13, 113-15.

Haselock, P.J. and Leslie, A.G. (1992). Polyphase deformation in Grampian Group rocks of the Monadhliath defined by a group magnetic survey. Scottish Journal of Geology 28, 81-7.

Haselock, P.J., Winchester, J.A. and Whittles, K.H. (1982). The stratigraphy and structure of the southern Monadhliath Mountains between Loch Killin and upper Glen Roy. Scottish Journal of Geology, 18, 275-90.

Heddle, M.F. (1878) Chapters on the mineralogy of Scotland. Chapter fourth - augite, hornblende and serpentinous change. Transactions of the Royal Society of Edinburgh 28, 453-555.

Heddle M. F. (1901) The mineralogy of Scotland. D. Douglas, Edinburgh.

Henderson, S.M.K. (1938) The Dalradian Succession of the Southern Highlands. Report of the meeting of the British Association for the Advancement of Science, Cambridge, 1938, 424. 
Henderson, W.G. and Robertson, A.H.F. (1982). The Highland Border rocks and their relation to marginal basin development in the Scottish Caledonides. Journal of the Geological Society of London, 139, 433-50.

Henderson, W.G., Tanner, P.W.G. and Strachan, R.A. (2009) The Highland Border Ophiolite of Scotland: observations from the Highland Workshop field excursion of April 2008. Scottish Journal of Geology, 45, 13-18.

Hibbert, S. (1822) A Description of the Shetland Islands: comprising an account of their geology, scenary, antiquities and superstitions. Constable and Co., Edinburgh.

Hickman, A.H. (1975) The stratigraphy of late Precambrian metasediments between Glen Roy and Lismore. Scottish Journal of Geology, 11, 117-42.

Hickman, A H. (1978) Recumbent folds between Glen Roy and Lismore. Scottish Journal of Geology, 14, 191-212.

Hickman, A.H. and Roberts, J.L. (1977). Discussion of the North Ballachulish Dalradian. Journal of the Geological Society of London, 133, Part 3, 277-79.

Hickman, A.H. and Wright, A.E. (1983) Geochemistry and chemostratigraphical correlation of slates, marbles and quartzites of the Appin Group, Argyll, Scotland. Transactions of the Royal Society of Edinburgh: Earth Sciences, 73, 251-78.

Highton, A.J. (1986). Caledonian and pre-Caledonian events in the Moine south of the Great Glen Fault, Unpublished PhD thesis, University of Liverpool.

Highton, A.J. (1992). The tectonostratigraphical significance of pre-750 Ma metagabbros within the northern Central Highlands, Inverness-shire. Scottish Journal of Geology 28, 71-6.

Highton, A.J. (1999). Solid Geology of the Aviemore District. Memoir of the British Geological Survey, Sheet 74E (Scotland).

Highton, A.J., Hyslop, E.K. and Noble, S.R. (1999).U-Pb zircon geochronology of migmatization in the northern Central Highlands: evidence for pre-Caledonian (Neoproterozoic) tectonmetamorphism in the Grampian Block, Scotland. Journal of the Geological Society, London, 156, 1195-204.

Hill, J.B. (1899) on the progressive metamorphism of some Dalradian sediments in the region of Loch Awe. Quarterly Journal of the Geological Society, London, 40, 470-93.

Hill, J.B. (1905) The geology of mid-Argyll. Memoirs of the Geological Survey, Scotland. Explanation of Sheet 37.

Hill, J. and Buist, D. (1994) A Geological Field Guide to the Island of Bute, Scotland. (editor Greensmith, J. T.) Geologists' Association Guide, No. 51, 95 pp. Warwick Press.

Hinxman, L.W. (1896). Explanation of Sheet 75. West Aberdeenshire, Banffshire, parts of Elgin and Inverness. Memoir of the Geological Survey, Scotland.

Hinxman, L. W. and Anderson, E. M. (1915). The geology of MidStrathspey and Strathdearn, including the country between Kingussie and Grantown, Scotland. Memoir of the Geological Survey, Scotland, sheet 74 (Scotland).

Hinxman, L. W., Carruthers, R. G. and Macgregor, M. (1923). The geology of Corrour and the Moor of Rannoch. Memoir of the Geological Survey, Scotland, sheet 54 (Scotland).

Hinxman, L.W. and Grant Wilson, J.S. (1902) The geology of Lower Strathspey. Memoir of the Geological Survey, Scotland, Sheet 85 (Scotland). 
Hoffmann, P.F., Condon, D.J., Bowring, S.A. and Crowley, J.L. (2004) U-Pb zircon date from the Neoproterozoic Ghaub Formation, Namibia: Constraints on Marinoan glaciation. Geology, 32, 817-20.

Holdsworth, R.E., Woodcock, N. and Strachan, R. (2000) Geological Framework of Britain and Ireland. In Geological History of Britain and Ireland (edited by Woodcock, N. and Strachan, R.) Blackwell Science, Oxford.

Holland, C.H. and Sanders, I.S. (editors) 2009. The Geology of Ireland (2nd edition). Dunedin Academic Press, Edinburgh. $576 \mathrm{pp}$.

Howarth, R.J. and Leake, B.E. (2002) The Life of Frank Coles Phillips (1902-1982) and the Structural Geology of the Moine Petrofabric Controversy. Memoir of the Geological Society, London, 23, $95 \mathrm{pp}$.

Hudson, N.F.C. (1976) Mineral facies in pelitic rocks, with particular reference to the Buchan type metamorphism of northeastern Scotland. Unpublished PhD thesis, University of Edinburgh.

Hudson, N.F.C. (1980) Regional metamorphism of some Dalradian pelites in the Buchan area, NE Scotland. Contributions to Mineralogy and Petrology, 73, 39-51.

Hudson, N.F.C. (1985) Conditions of Dalradian metamorphism in the Buchan area. Journal of the Geological Society of London, 142, $63-76$.

Hutchison, A.R. and Oliver, G.J.H. (1998) Garnet provenance studies, juxtaposition of Laurentian marginal terranes and timing of the Grampian Orogeny in Scotland. Journal of the Geological Society, London, 155, 541-50.

Hutton D.H.W. (1987) Strike slip terranes and a model for the evolution of the British and Irish Caledonides. Geological Magazine 124, 405-425.

Hutton, D.H.W. and Alsop, G.I. (2004) Evidence for a major Neoproterozoic orogenic unconformity within the Dalradian Supergroup of NW Ireland. Journal of the Geological Society, London, 161, 629-40.

Hutton, D.H.W. and Alsop, G.I. (2005) Discussion on evidence for a major Neoproterozoic orogenic unconformity within the Dalradian Supergroup of NW Ireland. Journal of the Geological Society, London, 162, 221-4.

Hutton J. (1788) Theory of the Earth; or an Investigation of the Laws observable in the Composition, Dissolution, and Restoration of the Land upon the Globe. Transactions of the Royal Society of Edinburgh 1, 209-304.

Hyslop, E. K. (1992). Strain-induced metamorphism and pegmatite development in the Moine rocks of Scotland. Unpublished PhD thesis, University of Hull.

Hyslop, E.K. and Piasecki, M.A.J. (1999). Mineralogy, geochemistry and the development of ductile shear zones in the Grampian Slide Zone of the Scottish Central Highlands. Journal of the Geological Society, London, 156, 577-90.

Hyslop, E.K. and Pickett, E.A. (1999) Stratigraphy and magmatism in the uppermost Dalradian of the SW Scottish Highlands: A field excursion to Tayvallich, Loch Avich and Tarbert (Loch Fyne). BGS Technical Report WA/99/73.

Indares, A. and Dunning, G.R. (1997) Coronitic metagabbro and eclogite from the Grenville Province of western Quebec; interpretation of $\mathrm{U}-\mathrm{Pb}$ geochronology and metamorphism. Canadian Journal of Earth Sciences 34, 891-901. 
Jacques J.M. and Reavy R.J. (1994) Caledonian plutonism and major lineaments in the SW Scottish Highlands. Journal of the Geological Society, London, 151, 955-69.

Jamieson, T.F. (1861) On the structure of the south-west Highlands of Scotland. Quarterly Journal of the Geological Society of London, 17, 133-45.

Jehu, T.J. and Campbell, R. (1917) The Highland Border rocks of the Aberfoyle District. Transactions of the Royal Society of Edinburgh, 52, 175-212.

Johnson, M.R.W. (1962) Relations of movement and metamorphism in the Dalradians of Banffshire. Transactions of the Edinburgh Geological Society, 19, 29-64.

Johnson, M.R.W. (1963) Some time relations of movement and metamorphism in the Scottish Highlands. Geologie en Mijnbouw, 42, $121-42$.

Johnson, M.R.W. (1965) Dalradian. In The Geology of Scotland (1st edition). Craig, G. Y. (ed.) Oliver and Boyd, Edinburgh. 117-60.

Johnson, M.R.W. (1983) Dalradian. In Geology of Scotland (2nd edition), Craig, G. Y. (ed.), Scottish Academic Press, Edinburgh, pp. 77-104.

Johnson, M.R.W. (1991) Dalradian. In Geology of Scotland (3rd edition). Craig, G. Y. (ed.) The Geological Society, London, pp. $125-60$.

Johnson, M.R.W. and Harris, A.L. (1967) Dalradian-?Arenig relations in part of the Highland Border, Scotland, and their significance in the chronology of the Caledonian orogeny. Scottish Journal of Geology, 3, 1-16.

Johnson, M.R.W. and Stewart, F.H. (1960) On Dalradian structures in north-east Scotland. Transactions of the Edinburgh Geological Society, 18, 94-103.

Johnson T.E. (1999) Partial melting in Dalradian pelitic migmatites from the Fraserburgh-Inzie Head area of Buchan, northeast Scotland. Unpublished PhD thesis, University of Derby.

Johnson T.E., Hudson N.F.C. and Droop G.T.R. (2001a) Partial melting in the Inzie Head gneisses: the role of water and a petrogenetic grid in KFMASH applicable to anatectic pelitic migmatites. Journal of Metamorphic Geology, 19, 99-118.

Johnson T.E., Hudson N.F.C. and Droop, G.T.R (2001b) Melt segregation structures within the Inzie Head gneisses of the northeastern Dalradian. Scottish Journal of Geology, 37, 59-72.

Johnson T.E., Hudson N.F.C. and Droop G.T.R. (2003) Evidence for a genetic granite-migmatite link in the Dalradian of $\mathrm{NE}$ Scotland. Journal of the Geological Society, London, 160, 447- 57.

Johnstone, G.S. (1966) British regional geology: the Grampian Highlands (3rd edition). HMSO, Edinburgh for Geological Survey and Museum.

Johnstone, G.S. (1975) The Moine Succession. In A Correlation of Precambrian Rocks in the British Isles (eds. Harris, A. L., Shackleton, R. M., Watson, J.V., Downie, C., Harland, W. B. and Moorbath, S.) Geological Society, London, Special Report, 6, 3042.

Johnstone, G.S. and Smith, D.I. (1965) Geological observations concerning the Breadalbane Hydroelectric Project, Perthshire. Bulletin of the Geological Survey of Great Britain, 22, 1-52. 
Johnstone, G.S. and Wright, J.E. (1957) The Geology of the tunnels of the Loch Sloy hydroelectric scheme. Bulletin of the Geological Survey of Great Britain, 12, 1-17.

Jones, K.A. (1959) The tectonic and metamorphic history of the Ben More-Am Binnein area, Western Perthshire. Unpublished PhD thesis, University of Wales, Swansea.

Kearns, S. (1989) Metamorphism of calc-silicate and related rocks from the Dalradian of N.E. Scotland. Unpublished PhD thesis, Derbyshire College of Higher Education.

Kennedy, M.J. (1975) The Fleur de Lys Supergroup: stratigraphic comparison of Moine and Dalradian equivalents in Newfoundland with the British Caledonides. Journal of the Geological Society, London, 131, 305-10.

Kennedy W.Q. (1946) The Great Glen Fault. Quarterly Journal of the Geological Society of London, 102, 41-76.

Kennedy, W.Q. (1948) On the significance of thermal structure in the Scottish Highlands. Geological Magazine, 85, 229-34.

Kessler, L.G. and Gollop, I.G. (1988) Inner shelf/shorefaceintertidal transition, Upper Precambrian, Port Askaig Tillite, Isle of Islay, Argyll, Scotland. In Tide Influenced Sedimentology, Environments and Facies (eds. de Boer, P. L., van Gelder, A. and Nio, S. D.), Reidal, Dohdrecht, pp. 341-58.

Key, R.M., Clark, G.C., May, F., Phillips, E.R., Chacksfield, B.C. and Peacock, J.D. (1997). Geology of the Glen Roy district. Memoir of the British Geological Survey, sheet 63W (Scotland).

Kilburn, C., Pitcher, W.S. and Shackleton, R.M. (1965) The stratigraphy and origin of the Portaskaig Boulder Bed series (Dalradian). Geological Journal, 4, 343-60.

Kinny, P.D., Friend, C.R.L., Strachan, R.A., Watt, G.R. and Burns, I.M. (1999) U-Pb geochronology of regional migmatites in East Sutherland, Scotland; evidence for crustal melting during the Caledonian Orogeny. Journal of the Geological Society, London, 156, 1143-52.

Kinny, P.D., Strachan, R.A., Friend, C.R.L., Kocks, H., Rogers, G. and Paterson, B.A. (2003a) U-Pb geochronology of deformed metagranites in central Sutherland, Scotland; evidence for widespread late Silurian metamorphism and ductile deformation of the Moine Supergroup during the Caledonian orogeny. Journal of the Geological Society of London, 160, 259-69.

Kinny, P.D., Strachan, R.A., Kocks, H. and Friend, C.R.L. (2003b) $\mathrm{U}-\mathrm{Pb}$ geochronology of late Neoproterozoic augen granites in the Moine Supergroup, NW Scotland: dating of rift-related, felsic magmatism during supercontinent break-up? Journal of the Geological Society of London, 160, 925-34.

Klein, G.D.V. (1970) Tidal origin of a Precambrian quartzite - the Lower Fine-grained Quartzite (Middle Dalradian) of Islay, Scotland. Journal of Sedimentary Petrology, 40, 973-85.

Klein, G.D.V. (1971) Tidal origin of a Precambrian quartzite - the Lower Fine-grained Quartzite (Middle Dalradian) of Islay, Scotland: Reply. Journal of Sedimentary Petrology, 41, 886-9.

Kneller, B.C. (1985) Dalradian basin evolution and metamorphism. Journal of the Geological Society of London, 142, 4 (abstract).

Kneller, B.C. (1987) A geological history of NE Scotland. 1-50. In Excursion guide to the geology of the Aberdeen area. Trewin, 
H.N., Kneller, B.C. and Gillen, C. (editors). Scottish Academic Press for Geological Society of Aberdeen, Edinburgh.

Kneller, B.C. (1988) The geology of part of Buchan. Unpublished PhD thesis, University of Aberdeen.

Kneller, B.C. and Aftalion M. (1987) The isotopic and structural age of the Aberdeen Granite. Journal of the Geological Society of London 144, 717-21.

Kneller, B.C. and Leslie, A.G. (1984) Amphibolite facies metamorphism in shear zones in the Buchan area of NE Scotland. Journal of Metamorphic Geology 2, 83-94.

Knill, J.L. (1959) Palaeocurrents and sedimentary facies of the Dalradian metasediments of the Craignish-Kilmelfort district. Proceedings of the Geologists' Association, 70, 273-84.

Knill, J.L. (1960) The tectonc pattern in the Dalradian of the Craignish-Kilmelfort District, Argyllshire. Quarterly Journal of the Geological Society of London, 115, 339-64.

Knill, J.L. (1963) A sedimentary history of the Dalradian series. In The British Caledonides. (eds Johnson, M.R.W. and Stewart, F.H.). Oliver and Boyd, Edinburgh, pp. 99-121.

Krabbendam, M. and Leslie, A.G. (1996) Folds with vergence opposite to the sense of shear. Journal of Structural Geology, 18, 777-81.

Krabbendam, M., Leslie, A.G., Crane, A. and Goodman, S. (1997) Generation of the Tay Nappe, Scotland, by large-scale SE-directed shearing. Journal of the Geological Society, London, 154, 15-24.

Krabbendam, M., Prave, A.R. and Cheer, D.A. (2008) A fluvial origin for the Neoproterozoic Morar Group, NW Scotland; implications for Torridon-Morar Group correlation and the Grenville Orogen foreland basin. Journal of the Geological Society, London, 165, 379-94.

Kruhl, J. and Voll, G. (1975) Large scale pre-metamorphic and precleavage inversion at Loch Leven, Scottish Highlands. Neues Jahrbuch für Mineralogie, 2, 71-8.

Kynaston, H. and Hill J.B. (1908) The Geology of the country near oban and Dalmally. Memoir of the Geological Survey, sheet 45 (Scotland).

Lambert, R.St. J. (1975) Discussion of Moine-Dalradian relationships in the River Leven. Journal of the Geological Society of London, 131, 327-8.

Lambert, R.St.J., Holland, J.G. and Winchester, J.A. (1982) A geochemical comparison of the Dalradian Leven Schists and the Grampian Division Monadhliath Schists of Scotland. Journal of the Geological Society of London, 139, 71-84.

Lambert, R.St.J. and McKerrow, W.S. (1976) The Grampian Orogeny. Scottish Journal of Geology, 12, 271-92.

Lambert, R.St.J, Winchester, J.A. and Holland, J.G. (1981) Comparative geochemistry of pelites from the Moinian and Appin Group (Dalradian) of Scotland. Geological Magazine, $118,477-90$.

Lawson, J. D. and Weedon, D. S. (editors) (1992) Geological Excursions around Glasgow and Girvan. Geological Society of Glasgow, Glasgow.

Leake, B.E. (1982) Volcanism in the Dalradian. In Igneous rocks of the British Isles. Sutherland, D. S. (editor). John Wiley and Sons, Chichester, pp. 45-50.

Leake, B.E. and Tanner, P.W.G. (1994) The Geology of the Dalradian and Associated Rocks of Connemara, Western Ireland: a report to 
accompany the 1:63360 geological map and cross sections. Royal Irish Academy, Dublin.

Lee, G.W. and Bailey, E.B. (1925) The pre-Tertiary geology of Mull, Loch Aline and Oban. Memoir of the Geological Survey of Great Britain, Sheet 44 (Scotland).

Leggo, P.J., Tanner, P.W.G. and Leake, B.E. (1969) Isochron study of Donegal Granite and certain Dalradian rocks of Britain. In North Atlantic-geology and Continental Drift, a symposium (ed. M. Kay), Memoir of the American Association of Petroleum Geologists, 12 , pp. 354-62.

Le Maitre, R.W (editor) (2002). Igneous Rocks: a Classification and Glossary of Terms; Recommendations of the International Union of Geological Sciences Subcommission on the Systematics of Igneous Rocks. Cambridge University Press, Cambridge, $236 \mathrm{pp}$.

Leslie, A.G., Chacksfield, B.C., Smith, M. and Smith, R.A. (1999). The Geophysical signature of a major shear zone in the Central Highlands of Scotland. British Geological Survey Technical Report No. WA $/ 99 / 32 R$.

Leslie, A.G., Krabbendam, M. and Smith, R.A. (2006) The Gaick Fold Complex: large-scale recumbent folds and their implications for Caledonian structural architecture in the Central Grampian Highlands. Scottish Journal of Geology, 42, 149-60.

Leslie, A.G., Smith, M. and Soper, N.J. (2008) Laurentian margin evolution and the Caledonian orogeny-a template for Scotland and East Greenland. In The Greenland Caledonides: Evolution of the Northeast Margin of Laurentia. Higgins, A.K., Gilotti, J.A. and Smith, M.P. (editors), Geological Society of America Memoir, 202, 307-43.

Lindsay, N.G. (1988) Contrasts in Caledonian tectonics of the Northern and Central Highlands. Unpublished PhD thesis, University of Liverpool.

Lindsay, N.G., Haselock, P.J. and Harris, A.L. (1989). The extent of Grampian orogenic activity in the Scottish Highlands. Journal of the Geological Society of London, 146, 733-5.

Litherland, M. (1970) The stratigraphy and structure of the Dalradian rocks around Loch Creran, Argyll. Unpublished PhD thesis, University of Liverpool.

Litherland, M. (1975) Organic remains and traces from the Dalradian of Benderloch, Argyll. Scottish Journal of Geology, 11, 47-50.

Litherland, M. (1980) The stratigraphy of the Dalradian rocks around Loch Creran, Argyll. Scottish Journal of Geology, 16, 10523.

Litherland, M. (1982) The structure of the Loch Creran Dalradian and a new model for the SW Highlands. Scottish Journal of Geology, 18, 205-25.

Loudon, T.V. (1963) The sedimentation and structure in the Macduff District of North Banffshire and Aberdeenshire. Unpublished PhD thesis, University of Edinburgh.

Lowe, D. R. 1976. Subaqueous liquified and fluidised sediment flows and their deposits. Sedimentology, 23, pp. 285-308.

Lyubetskaya, T. and Ague, J.J., 2010. Modeling metamorphism in collisional orogens intruded by magmas: fluid flow and implications for Barrovian and Buchan metamorphism, Scotland. American Journal of Science, 310, 459-491.

McAteer, C.A., Daly, J.S., Flowerdew, M.J., Connelly, J.N., Housh, T.B. and Whitehouse, M.J. (2010) Detrital zircon, detrital 
titanite and igneous clast U-Pb geochronology and basement-cover relationships of the Colonsay Group, SW Scotland: Laurentian provenance and correlation with the Neoproterozoic Dalradian Supergroup. Precambrian Research, 181, 21-42.

McCallien, W.J. (1925) Notes on the Geology of the Tarbet district of Loch Fyne. Transactions of the Geological Society of Glasgow, 17, 233-63.

McCallien, W.J. (1926) The structure of South Knapdale (Argyll). Transactions of the Geological Society of Glasgow, 17, 377-94.

McCallien, W.J. (1929) The metamorphic rocks of Kintyre. Transactions of the Royal Society of Edinburgh, 56, 40936.

Mccallien, W.J. (1938) The Geology of Bute. Transactions of the Buteshire Natural History Society, 12, 84-112.

McCay, G.A., Prave, A.R., Alsop, G.I. and Fallick, A.E. (2006) Glacial trinity: Neoproterozoic Earth history within the BritishIrish Caledonides. Geology, 34, 909-12.

McClay, K.R. (1987) The Mapping of Geological Structures. Geological Society of London Handbook, Open University Press, Milton Keynes, $161 \mathrm{pp}$.

McClay K.R., Norton M.G., Cony P. and Davis G.H. (1986) Collapse of the Caledonian Orogen and the old Red Sandstone. Nature, London 323, 147-9.

MacCulloch, J. (1814) Remarks on several parts of Scotland which exhibit quartz rock, and on the nature and connexions of this rock in general. Transactions of the Geological Society, 2, 450-87.

MacCulloch, J. (1819) A description of the western islands of Scotland including the Isle of Man: comprising an account of their geological structure; with remarks on their agriculture, scenary and antiquities. 3 volumes. Constable, London.

MacDonald, J.G. and Herriot, A. (1983) Macgregor's excursion guide to the geology of Arran. (3rd edition). Geological Society of Glasgow and University of Glasgow, Glasgow.

Macdonald, R. and Fettes, D.J. (2007) The tectonomagmatic evolution of Scotland. Transactions of the Royal Society of Edinburgh: Earth Sciences, 97, 213-95.

Macdonald, R., Fettes, D.J., Stephenson, D. and Graham, C.M. (2005) Basic and ultrabasic volcanic rocks from the Argyll Group (Dalradian) of NE Scotland. Scottish Journal of Geology, 41, 15974 .

MacGregor, A.G. (1948) British regional geology: the Grampian Highlands (2nd edition), HMSO for Geological Survey and Museum, Edinburgh.

MacGregor, A.R. (1996) Edzell and Glen Esk. 93-108 in Fife and Angus Geology, an excursion guide (3rd edition) by A.R. MacGregor, Pentland Press, Durham.

MacGregor, S.M.A. and Roberts, J.L. (1963) Dalradian pillow lavas, Ardwell Bridge, Banffshire. Geological Magazine, 100, 17-23.

McIntyre, D.B. (1950) Lineation, boudinage and recumbent folding in the Struan Flags (Moine), near Dalnacardoch, Perthshire. Geological Magazine, 87, 205-25.

McIntyre, D.B. (1951) The tectonics of the area between Grantown and Tomintoul (mid-Strathspey). Quarterly Journal of the Geological Society of London, 107, 1-22.

McKenzie, D.P. and Bickle, M.J. (1988). The volume and composition of melt generated by the extension of the lithosphere. Journal of Petrology, 29, 625-79. 
Mckie, T. (1990) Tidal and storm-influenced sedimentation from a Cambrian transgressive passive margin sequence. Journal of the Geological Society, London, 147, 785-94.

Mackie, W. (1908) Evidence of contemporaneous volcanic action in the Banffshire schists. Transactions of the Edinburgh Geological Society, 9, 93-101.

McLellan, E.L. (1983) Barrovian migmatites and the thermal history of the south-eastern Grampians. Unpublished PhD thesis, University of Cambridge.

McLellan, E.L., 1985. Metamorphic reactions in the kyanite and sillimanite zones of the Barrovian type area, Journal of Petrology, 26, 789-818.

Macnair, P. (1896) The altered clastic rocks of the Southern Highlands: their structure and succession. Geological Magazine, Decade 4, 3, 167-174, 211-217.

Macnair, P. (1906) On the development of the great axial lines of folding in the Highland schists. Proceedings of the Royal Philosophical Society of Glasgow Vol. 37, 129-xxx.

Macnair, P. (1908) The Geology and Scenery of the Grampians and the Valley of Strathmore, James Maclehose and Sons, Glasgow, 2 volumes, $256 \mathrm{pp}$.

Marcantonio, F., Dickin, A.P., McNutt, R.H. and Heaman, L.M. (1988). A 1880-million year old Proterozoic gneiss terrane in Islay with implications for crustal evolution of Britain. Nature, $335,62-64$.

Mather, J.D. (1968) A geochemical, mineralogical and petrological study of rocks of lower greenschist facies from the Dalradian of Scotland. Unpublished PhD thesis, University of Liverpool.

May, F. (1970) Movement, metamorphism and migmatization in the Scalloway region of Shetland. Bulletin of the Geological Survey of Great Britain, 31, 205-26.

May, F. and Highton, A.J. (1997) Geology of the Invermoriston district. Memoir of the British Geological Survey. Sheet $73 \mathrm{~W}$ (Scotland).

Melezhik, V.A., Gorokhov, I.M., Kuznetsov, A.B. and Fallick, A.E. (2001). Chemostratigraphy of Neoproterozoic carbonates: implications for 'blind dating'. Terra Nova, 13, 1-11.

Mendum, J.R. 1987. Dalradian of the Collieston coast section. 161172 in Excursion guide to the geology of the Aberdeen area. Trewin, $\mathrm{N}$ H, Kneller, B C, and Gillen, C (editors). (Edinburgh: Scottish Academic Press for Geological Society of Aberdeen.)

Mendum, J.R., Barber, A.J., Butler, R.W.H., Flinn, D., Goodenough, K.M., Krabbendam, M., Park, R.G. and Stewart, A.D. (2009) Lewisian, Torridonian and Moine rocks of Scotland, Geological Conservation Review Series, No. 34, Joint Nature Conservation Committee, Peterborough, $722 \mathrm{pp}$.

Mendum, J.R. and Fettes, D.J. (1985) The Tay nappe and associated folding in the Ben Ledi-Loch Lomond area. Scottish Journal of Geology, 21, 41-56.

Mendum, J.R. and Noble, S.R. (2010) Mid-Devonian sinistral transpression on the Great Glen Fault: the rise of the Rosemarkie Inlier and the Acadian Event in Scotland. In Continental tectonics and mountain building: the legacy of Peach and Horne. (eds R.D. Law, R.W.H. Butler, R.E. Holdsworth, M. Krabbendam and R.A. Strachan), Geological Society, London, Special Publication, No. 335, pp. 161-187. 
Mendum, J.R. and Thomas, C.W. (1997) Discussion on the generation of the Tay Nappe, Scotland, by large-scale SE-directed shearing. Journal of the Geological Society, London, 154, 581-3.

Miall, A. D. 1985. Architectural-element analysis: a new method of facies analysis applied to fluvial deposits. Earth Science Reviews, 22, pp. 261-308.

Miall, A. D. 1992. Alluvial Deposits. In: Walker, R. G. \& James, N. P. (eds), Facies models - response to sea level changes. Geoscience Canada, pp. 119-1992.

Milar, I.L. (1999) Neoproterozoic extensional basic magmatism associated with the West Highland granite gneiss in the Moine Supergroup of NW Scotland. Journal of the Geological society, London 156, 1153-62.

Moffat, D.T. (1987) The serpentinized ultramafites of the Shetland Caledonides. Unpublished PhD thesis, University of Liverpool.

Moig, N.A.W. (1986) A structural study of the Dalradian rocks of the Banff coastal transect, NE Scotland. Unpublished PhD thesis, University of Dundee.

Moles, N.R. (1985a) Geology, geochemistry and petrology of the Foss stratiform baryte-base metal deposit and adjacent Dalradian metasediments, near Aberfeldy. Unpublished PhD thesis, University of Edinburgh.

Moles, N.R. (1985b) Metamorphic conditions and uplift history in central Perthshire: evidence from mineral equilibria in the Foss celsian-barite-sulphide deposit, Aberfeldy. Journal of the Geological Society of London, 142, 39-52.

Möller, C. (1998) Decompressed eclogites in the Sveconorwegian (Grenvilian) Orogen of SW Sweden; petrology and tectonic implications. Journal of Metamorphic Geology, 16, 641-56.

Molyneux, S.G. 1998. An upper Dalradian microfossil reassessed. Journal of the Geological Society, London, 155, 740-743.

Morgan, W.C. (1966) The metamorphic history of the Dalradian rocks between Tomintoul and Loch Builg, Banfshire. Unpublished Ph D thesis, University of Aberdeen.

Morris, G.A. and Hutton, D.H.W. (1993) Evidence for sinistral shear associated with the emplacement of the early Devonian Etive dyke swarm. Scottish Journal of Geology, 29, 69-72.

Mould, D.D.C.P. (1946) The geology of the Foyers 'granite' and the surrounding country. Geological Magazine, 83, 249-65.

Muir, R.J. (1990) The Precambrian basement and related rocks of the southern Inner Hebrides, Scotland. Unpublished PhD thesis, University of Wales, Aberystwyth.

Muir, R.J., Fitches, W.R. and Maltman, A.J. (1989) An Early Proterozoic link between Greenland and Scandinavia in the Inner Hebrides of Scotland. Terra Abstract, 1, 5.

Muir, R.J., Fitches, W.R. and Maltman, A.J. (1992). Rhinns Complex: a missing link in the Proterozoic basement of the North Atlantic region. Geology, 20, 1043-6.

Muir, R.J., Fitches, W.R. and Maltman, A.J. (1994a). The Rhinns Complex: Proterozoic basement on Islay and Colonsay, Inner Hebrides, Scotland, and on Inishtrahull, NW Ireland. Transactions of the Royal Society of Edinburgh: Earth Sciences, 85, 77-90.

Muir, R.J., Fitches, W.R., Maltman, A.J. and Bentley, M.R. (1994b) Precambrian rocks of the southern Inner Hebrides-Malin Sea region: Colonsay, west Islay, Inishtrahull and Iona. In: Gibbons, W. and Harris, A.L. (eds) A revised correlation of Precambrian rocks in 
the British Isles. Geological Society, London, Special Report 22, 54-58.

Muir, R.J., Fitches, W.R. and Maltman, A.J. (1995). The Colonsay Group and basement-cover relationship on the Rhinns of Islay, Inner Hebrides. Scottish Journal of Geology, 31, 125-30.

Munro, M. (1986) Geology of the country around Aberdeen. Memoir of the British Geological Survey, Sheet 77 (Scotland).

Munro, M. and Gallagher, J W. (1984) Disruption of the 'Younger Basic' masses in the Huntly-Portsoy area, Grampian Region. Scottish Journal of Geology, 20, 361-82.

Murchison, R.I. (1851) On the Silurian rocks of the south of Scotland. Quarterly Journal of the Geological Society of London, 7, $139-78$.

Murchison, R.I. (1859) Siluria: the History of the Oldest known Rocks Containing Organic Remains, With a Brief Sketch of the Distribution of Gold Over the Earth. 3rd edition. John Murray, London.

Murchison, R.I. and Geikie, A. (1861) On the altered rocks of the Western Islands of Scotland and the North-Western and Central Highlands. Quarterly Journal of the Geological Society of London 17, 171- ??.

Mutti, E. and Normark, W.R. (1987) Comparing examples of modern and ancient turbidite systems: problems and concepts. In Marine Clastic Sedimentology (eds. Legget, J.K and Zuffa, G.G.), Graham and Trotman, pp.1-38.

Mykura, W. (1976) British Regional Geology: Orkney and Shetland. HMSO, Edinburgh for the Institute of Geological Sciences.

Nell, P.A.R. (1984) The geology of lower Glen Lyon. Unpublished PhD thesis, University of Manchester.

Nell, P.A.R. (1986) Discussion on the Caledonian metamorphic core: an Alpine model. Journal of the Geological Society of London, $143,723-8$.

Nesbitt, R.W. and Hartmann, L.A. (1986) Comments on 'A peridotitic komatiite from the Dalradian of Shetland' by D. Flinn and D.T. Moffat. Geological Journal, 21, 201-5.

Nicol, J. (1844) Guide to the geology of Scotland: Containing an Account of the Character, Distribution and More Interesting Appearances of its Rocks and Minerals. Oliver and Boyd, Edinburgh.

Nicol, J. (1852) On the geology of the southern portion of the peninsula of Cantyre, Argylishire. Quarterly Journal of the Geological Society of London, 8, 406-25.

Nicol J. (1863) On the geological structure of the Southern Grampians. Quarterly Journal of the Geological Society of London $19,180-209$.

Noble, S.R., Hyslop, E.K. and Highton, A.J. (1996). High-precision $\mathrm{U}-\mathrm{Pb}$ monazite geochronology of the c. 806 Ma Grampian Shear Zone and the implications for evolution of the Central Highlands of Scotland. Journal of the Geological Society, London, 153, 511-14.

Okonkwo, C.T. (1985). The geology and geochemistry of the metasedimentary rocks of the Loch Laggan-Upper Strathspey area, Inverness-shire. Unpublished PhD thesis, University of Keele.

Okonkwo, C.T. (1988). The stratigraphy and structure of the metasedimentary rocks of the Loch Laggan-Upper Strathspey area, Inverness-shire. Scottish Journal of Geology, 24, 21-34. 
Oldroyd, D.R. and Hamilton, B.M. (2002) Themes in the early history of Scottish geology. In: Trewin N. H. (ed.) The Geology of Scotland. The Geological Society, London, pp. 27-43.

Oliver, G.J.H. (2001) Reconstruction of the Grampian episode in Scotland: its place in the Caledonian Orogeny. Tectonophysics, $332,23-49$.

Oliver, G.J.H. (2002) Chronology and terrane assembly, new and old controversies. In the Geology of Scotland (edited by Trewin, $N$. H.) The Geological Society, London, 201-11.

Oliver, G.J.H., Chen, F., Buchwald, R. and Hegner, E. (2000) Fast tectonometamorphism and exhumation in the type area of the Barrovian and Buchan zones. Geology, 28, 459-62.

Oliver, G.J.H., Simon, A.W., Wan, Y., 2008. Geochronology and geodynamics of Scottish granitoids from the late Neoproterozoic break-up of Rodinia to Palaeozoic collision. Journal of the Geological Society, London, 165, 661-674.

Pankhurst, R.J. (1970) The geochronology of the basic igneous complexes. Scottish Journal of Geology, 6, 83-107.

Pankhurst, R.J. and Pidgeon, R.T. (1976) Inherted isotope systems and the source region prehistory of the early Caledonian granites in the Dalradian Series of Scotland. Earth and Planetary Science Letters, 31, 58-66.

Pantin, H.M. (1952) Part 1: The petrology and structure of the Ben Vrackie epidiorite. Part 2: Some new observations on Dalradian stratigraphy and tectonics. Unpublished PhD thesis, University of Cambridge.

Pantin H.M. (1961) The stratigraphy and structure of the Blair Atholl-Ben a' Gloe area, Perthshire, Scotland. Transactions of the Royal Society of New Zealand, 88, 597-622.

Park, R.G. (1992) Plate kinematic history of Baltica during the Middle to Late Proterozoic: a model. Geology 20, 725-8.

Park, R.G. (1994) Early Proterozoic tectonic overview of the northern British Isles and neighbouring terrains in Laurentia and Baltica. Precambrian Research, 68, 65-79.

Parson, L M. (1982) The Precambrian and Caledonian geology of the ground near Fort Augustus, Inverness-shire. Unpublished PhD thesis, University of Liverpool.

Paterson, I.B., Hall, I.H.S. and Stephenson, D. (1990) Geology of the Greenock district. Memoir of the British Geological Survey, Sheet $30 \mathrm{~W}$ and part of sheet 29E (Scotland).

Pattrick, R.A. and Treagus, J.E. (1996) Economic geology of the Schiehallion district, central highlands of Scotland. British Geological Survey Technical Report No. WA/96/89.

Peach, B.N. (1904) Summary of Progress of the Geological Survey of the United Kingdom for 1903, 69.

Peach, B.N. and Horne, J. (1930) Chapters on the Geology of Scotland, Oxford University Press, London.

Peach, B.N., Kynaston, B.A. and Muff, H.B. (1909) The geology of the seaboard of mid Argyll including the islands of Luing, Scarba, the Garvellachs, and the Lesser Isles, together with the northern part of Jura and a small portion of Mull. Memoirs of the Geological Survey of Scotland, sheet 36.

Peach, B.N., Wilson, J.G.S., Hill, J.B., Bailey, E.B. and Grabham, G.W. (1911) The Geology of Knapdale, Jura and North Kintyre. Memoirs of the Geological Survey of Scotland, sheet 28. 
Peach, B.N. and Horne, J. (1930) Chapters on the Geology of Scotland, Oxford University Press, Oxford.

Peacock, J.D., Berridge, N.G., Harris, A.L. and May, F. (1968) The geology of the Elgin district. Memoir of the Geological Survey of Scotland, Sheet 95 (Scotland).

Phillips, E.R. (1996) The mineralogy and petrology of the igneous and metamorphic rocks exposed in the Macduff district (Sheet 96E), Northeast Scotland. British Geological Survey, Mineralogy and Petrology Technical Report, wG/96/26.

Phillips, E.R. and Auton, C.A. (1997) Ductile fault rocks and metamorphic zonation in the Dalradian of the Highland Border SW of Stonehaven, Kincardineshire. Scottish Journal of Geology, 33, 8393.

Phillips, E.R., Clark, G.C. and Smith, D.I. (1993) Mineralogy, petrology, and microfabric analysis of the Eilrig Shear Zone, Fort Augustus, Scotland. Scottish Journal of Geology, 29, 143-58.

Phillips, E.R., Hyslop, E.K., Highton, A.J and Smith, M. (1999). The timing and $\mathrm{P}-\mathrm{T}$ conditions of regional metamorphism in the Central Highlands. Journal of the Geological Society, London, 156, 1183-93.

Phillips, F.C. (1930) Some mineralogical and chemical changes induced by progressive metamorphism in the Green Bed group of the Scottish Dalradian. Journal of the Mineralogical Society, 22, $240-$ 256.

Phillips, F.C. (1954) The Use of Stereographic Projection in Structural Geology, Arnold, London.

Phillips, W.E.A., Stillman, C.J. and Murphy, T. (1976) A Caledonian plate tectonic model. Journal of the Geological Society of London, $132,579-609$.

Piasecki M.A.J. (1975) Tectonic and metamorphic history of the Upper Findhorn, Inverness-shire, Scotland. Scottish Journal of Geology, 11, 87-115.

Piasecki, M.A.J. (1980). New light on the Moine rocks of the Central Highlands of Scotland. Journal of the Geological Society of London, 137, 41-59.

Piasecki, M.A.J. and van Breemen, O. (1979a) A Morarian age for the "younger Moines" of central and western Scotland. Nature, London, 278, 734-6.

Piasecki, M.A.J. and van Breemen, O. (1979b). The 'Central Highland Granulites': cover-basement tectonics in the Moine. In The Caledonides of the British Isles - reviewed. (editors. Harris, A.L., Holland, C.H. and Leake, B.E.), The Geological Society of London, Special Publications, 8, 139-44.

Piasecki, M.A.J. and van Breemen, O. (1983) Field and isotopic evidence for a c. 750 Ma tectonothermal event in Moine rocks in the Central Highland region of the Scottish Caledonides. Transactions of the Royal Society of Edinburgh: Earth Sciences, 73, 119-34.

Piasecki, M.A.J., van Breemen, O. and Wright, A.E. (1981) Late Precambrian geology of Scotland, England and Wales. In Geology of the North Atlantic Borderlands, Kerr, J.W. and Fergusson, A.J. (eds). Memoir of the Canadian Society of Petroleum Geologists, 7, 57-94.

Piasecki, M.A.J. and Temperley, S. (1988a). The Central Highland Division. In: Winchester, J.A. (ed) Later Proterozoic stratigraphy of the Northern Atlantic regions. Blackie, Glasgow and London, 4653 . 
Piasecki, M.A.J. and Temperley, S. (1988b). The northern sector of the central Highlands. 51-68 in An excursion guide to the Moine geology of the Scottish Highlands. Allison, I, May, F, and Strachan, R A (editors). (Edinburgh: Scottish Academic Press for Edinburgh Geological Society and Geological Society of Glasgow.)

Pickering K.T., Bassett M.G., and Siveter D.J. (1988) Late Ordovician-early Silurian destruction of the Iapetus Ocean: Newfoundland, British Isles and Scandinavia: A discusion. Transactions of the Royal Society of Edinburgh: Earth Sciences, 79, 361-82.

Pickett, E.A. (1997) An introduction to the Green Beds of the Southern Highland Group: previous research and an account of preliminary work carried out in 1997. British Geological Survey Technical Report WA/97/92.

Pickett, E.A., Hyslop, E.K. and Petterson, M.G. (2006) The Green Beds of the SW Highlands: deposition and origin of a basic igneous-rich sedimentary sequence in the Dalradian supergroup of Scotland. Scottish Journal of Geology, 42, 43-57.

Pidgeon R.T. and Compston W. (1992) A Shrimp ion microprobe study of inherited and magmatic zircon from Scottish Caledonian granites. Transactions of the Royal Society, Edinburgh: Earth Sciences, 83, 473-83.

Pitcher, W.S. and Berger, A.R. (1972) The Geology of Donegal: a study of granite emplacement and unroofing. Wiley-Interscience, New York, $435 \mathrm{pp}$.

Plant, J.A., Stone, P. and Mendum, J.R. (1999) Regional geochemistry, terrane analysis and metallogeny in the British Caledonides. In Continental Tectonics. MacNiocaill, C and Ryan, P.D. (editors), Geological Society, London, Special Publication No $164,109-26$.

Plant, J.A., Watson, J.V. and Green, P.M. (1984) Moine-Dalradian relationships and their palaeotectonic significance. Proceedings of the Royal Society, 395a, 185-202.

Powell, R. and Evans, J.A. (1983). A new geobarometer for the assemblage biotite-muscovite-chlorite-quartz. Journal of Metamorphic Geology, 1, 331-6.

Power, M.R. and Pirrie, D. (2000) Platinum-group mineralization within ultramafic rocks at Corrycharmaig, Perthshire: implications for the origin of the complex. Scottish Journal of Geology, 36, 143-50.

Prave, A.R. (1999) The Neoproterozoic Dalradian Supergroup of Scotland: an alternative hypothesis. Geological Magazine, 136, 609-17.

Prave, A.R., Fallick, A.E., Thomas, C.W. and Graham, C.M. (2009a) A composite C-isotope profile for the Neoproterozoic Dalradian Supergroup of Scotland and Ireland. Journal of the Geological Society, 166, 845-857.

Prave, A.R., Strachan, R.A. and Fallick, A.E. (2009b) Global C cycle perturbations recorded in marbles: a record of Neoproterozoic Earth history within the Dalradian succession of the Shetland Islands, Scotland. Journal of the Geological Society, 166, 129-135.

Pringle, I.R. (1972) Rb-Sr age determinations on shales associated with the Varanger Ice Age. Geological Magazine, 109, 465-72.

Pringle, J. (1940) The discovery of Cambrian trilobites in the Highland Border rocks near Callander, Perthshire (Scotland). 
British Association for the Advancement of Science: Annual Report for 1939-40, 1, 252.

Pumpelly, R., Wolff, J.E. and Dale, T.N. (1894) Geology of the Green Mountains. United States Geological Survey Memoir, 23, 1157 .

Rainbird, R.H., Hamilton, M.A. and Young, G.M. (2001) Detrital zircon geochronology and provenance of the Torridonian, NW Scotland. Journal of the Geological Society, London, 158, 15-27.

Ramsay, D.M. (1959) Structure and metamorphism of Glen Lyon. Unpublished PhD thesis, University of Glasgow.

Ramsay, D.M. and Sturt, B.A. (1979) The status of the Banff Nappe. In The Caledonides of the British Isles-reviewed. Harris, A L, Holland, C H and Leake, B E (editors). Special Publication of the Geological Society of London, No. 8. 145-151

Ramsay, J.G. (1958) Moine-Lewisian relations at Glenelg, Invernessshire. Quarterly Journal of the Geological Society of London 113, 487-523.

Rast, N. (1956) Tectonics of Central Perthshire. Unpublished PhD thesis, University of Glasgow.

Rast, N. (1958) Metamorphic history of the Schiehallion complex, Perthshire. Transactions of the Royal Society of Edinburgh, 64, 413-31.

Rast, N. (1963). Structure and metamorphism of the Dalradian rocks of Scotland. In The British Caledonides. (editors. Johnson, M.R.W. and Stewart, F.H.). Oliver and Boyd, Edinburgh, 123-42.

Rast, N. and Litherland, M. (1970) The correlation of the Ballachulish and Perthshire (Islay) successions. Geological Magazine, 107, 259-72.

Read, H.H. (1919) The two magmas of Strathbogie and Lower Banffshire. Geological Magazine 56, 364-71.

Read, H.H. (1923) The geology of the country around Banff, Huntly, and Turriff, Lower Banffshire and north-west Aberdeenshire. Memoir of the Geological Survey, Scotland. Sheets 86 and 96 (Scotland).

Read, H.H. (1927) The igneous and metamorphic history of Cromar, Deeside. Transactions of the Royal Society of Edinburgh, 55, 31753.

Read, H.H. (1928) The Highland Schists of middle Deeside and east Glen Muick. Transactions of the Royal Society of Edinburgh, 55, $755-72$.

Read, H.H. (1933). On quartz-kyanite rocks in Unst, Shetland Islands, and their bearing on metamorphic differentiation. Mineralogical Magazine, 23, 317-28.

Read, H.H. (1934) The metamorphic geology of Unst in the Shetland Islands. Quarterly Journal of the Geological Society of London 90, 637-88.

Read, H.H. (1935) British Regional Geology: the Grampian Highlands (1st edition). HMSO for Geological Survey and Museum, Edinburgh.

Read, H.H. (1936) The stratigraphical order of the Dalradian rocks of the Banffshire coast. Geological Magazine, 73, 468-75.

Read, H.H. (1937) Metamorphic correlation in the polymetamorphic rocks of the Valla Field Block, Unst, Shetland Islands. Transactions of the Royal Society of Edinburgh, 59, 195-221.

Read, H.H. (1952) Metamorphism and migmatisation in the Ythan Valley, Aberdeenshire. Transactions of the Edinburgh Geological Society, 15, 265-79. 
Read, H.H. (1955) The Banff nappe: an interpretation of the structure of the Dalradian rocks of north-east Scotland. Proceedings of the Geologists' Association, 66, 1-29.

Read, H.H. (1960) North-east Scotland: the Dalradian. Geologists' Association Guide, 31. Benham and Co., Colchester.

Read, H.H. and Farquhar, O.C. (1956) The Buchan Anticline of the Banff Nappe of Dalradian rocks in north-east Scotland. Quarterly Journal of the Geological Society of London, 112, 131-56.

Richardson, S.W. and Powell, R. (1976) Thermal causes of the Dalradian metamorphism in the Central Highlands of Scotland. Scottish Journal of Geology, 12, 237-68.

Ritchie, J.D. and Hitchen, K. (1993) Discussion on the location and history of the Walls Boundary fault and Moine thrust north and south of Shetland. Journal of the Geological Society, London, 150, 1003-8.

Roberts, J.L. (1959) Fold Structures in the Dalradian Rocks of Knapdale, Argyllshire. Geological Magazine, 94, 221-9.

Roberts, J.L. (1963) The Dalradian of the southwest highlands of Scotland. Unpublished PhD thesis, University of Liverpool.

Roberts, J.L. (1966a) Sedimentary affiliations and stratigraphic correlation of the Dalradian rocks in the South-west Highlands of Scotland. Scottish Journal of Geology, 2, 200-23.

Roberts, J.L. (1966b) The formation of similar folds by inhomogeneous plastic strain, with reference to the fourth phase of deformation affecting the Dalradian rocks in the southwest Highlands of Scotland. Journal of Geology, 74, 831-55.

Roberts, J.L. (1974) The structure of the Dalradian rocks in the SW Highlands of Scotland. Journal of the Geological Society of London, 130, 93-124.

Roberts, J.L. (1976) The structure of the Dalradian rocks in the north Ballachulish district of Scotland. Journal of the Geological Society of London, 132, 139-54.

Roberts, J.L. (1977a) The evolution and transport of the Tay Nappe: Discussion. Scottish Journal of Geology, 13, 79-80.

Roberts, J.L. (1977b) The Dalradian rocks of Rosneath and Southeast Cowal. Scottish Journal of Geology, 13, 101-11.

Roberts, J.L. (1977c) The Dalradian rocks of Knapdale and North Kintyre. Scottish Journal of Geology, 13, 113-124.

Roberts, J.L. and Sanderson, D.J. (1974) Oblique fold axes in the Dalradian rocks of the Southwest Highlands. Scottish Journal of Geology, 9, 281-96.

Roberts, J.L. and Treagus, J.E. (1964) A reinterpretation of the Ben Lui Fold. Geological Magazine, 101, 512-16.

Roberts, J.L, and Treagus, J.E. (1975) The structure of the Moine and Dalradian rocks in the Dalmally district of Argyllshire, Scotland. Geological Journal, 10, 59-74.

Roberts, J.L, and Treagus, J.E. (1977a) The Dalradian rocks of the South-west Highlands-Introduction. Scottish Journal of Geology, Vol. 13, 87-99.

Roberts, J.L. and Treagus, J.E. (1977b) The Dalradian rocks of the Loch Leven area. Scottish Journal of Geology, 13, 165-184.

Roberts, J.L. and Treagus, J.E. (1977C) Polyphase generation of nappe structures in the Dalradian rocks of the Southwest Highlands of Scotland. Scottish Journal of Geology. 13, 237-254.

Roberts, J.L, and Treagus, J.E. (1979) Stratigraphical and structural correlation between the Dalradian rocks of the $\mathrm{SW}$ and Central Highlands of Scotland. 199-204 in The Caledonides of the 
British Isles-reviewed. Harris, A.L., Holland, C.H., and Leake, B.E. (editors). Special Publication of the Geological Society of London. 8 .

Roberts, J.L, and Treagus, J E. (1980) The structural interpretation of the Loch Leven area. Scottish Journal of Geology, 16, 73-5.

Robertson, S. (1991) Older granites in the south-eastern Scottish Highlands. Scottish Journal of Geology, 27, 21-6.

Robertson, S. (1994) Timing of Barrovian metamorphism and 'Older Granite' emplacement in relation to Dalradian deformation. Journal of the Geological Society of London, 151, 5-8.

Robertson, S. (1999) BGS Rock Classification Scheme Volume 2: Classification of metamorphic rocks. British Geological Survey Research Report, RR 99-02.

Robertson, S. and Smith, M. (1999) The significance of the Geal charn-Ossian Steep Belt in basin development in the Central Scottish Highlands. Journal of the Geological Society, London, 156, 1175-82.

Rock, N.M.S. (1985) A compilation of analytical data for metamorphic limestones from the Scottish Highlands and Islands, with lists of BGS registered samples, and comments on the reproducibility and accuracy of limestone analyses by different analytical techniques. Mineralogical and Petrological Report British Geological Survey, No. 85/5.

Rock, N.M.S. (1986) Chemistry of the Dalradian (Vendian-Cambrian) metalimestones, British Isles. Chemical Geology, 56, 289-311.

Rock, N.M.S., Macdonald, R. and Bower, J. (1986) The comparative geochemistry of some Highland pelites (Anomalous local limestonepelite successions within the Moine outcrop; II). Scottish Journal of Geology, 22, 107-26.

Rogers, G., Dempster, T.J., Bluck, B.J. and Tanner, P.W.G. (1989) A high precision U-Pb age for the Ben Vuirich Granite: implications for the evolution of the Scottish Dalradian Supergroup. Journal of the Geological Society, London, 146, 789-98.

Rogers, G., Hyslop, E.K., Strachan, R.A., Paterson, B.A. and Holdsworth, R.A. (1998) The structural setting and U-Pb geochronology of the Knoydartian pegmatites of $W$ Inverness-shire: evidence for Neoproterozoic tectonothermal events in the Moine of NW Scotland. Journal of the Geological Society, London, 155, 68596.

Rogers, G., Kinny, P.D., Strachan, R.A., Friend, C.R.L. and Patterson, B.A. (2001) U-Pb geochronology of the Fort Augustus granite gneiss, constraints on the timing of Neoproterozoic and Paleozoic tectonothermal events in the NW Highlands of Scotland. Journal of the Geological Society, London, 158, 7-14.

Rogers, G. and Pankhurst, R.J. (1993) Unravelling dates through the ages: geochronology of the Scottish metamorphic complexes. Journal of the Geological Society, London, 150, 447-64.

Rollin, K.E. (1994) Geophysical correlation of Precambrian rocks in northern Britain. In A Revised Correlation of Precambrian Rocks in the British Isles. Gibbons, W. and Harris, A.L. (eds.) Geological Society, London, Special Report, 22, 65-74.

Rooney, A.D., Chew, D.M. and Selby, D. (2011) Re - Os geochronology of the Neoproterozoic - Cambrian Dalradian Supergroup of Scotland and Ireland: implications for Neoproterozoic stratigraphy, glaciations and Re - Os systematics. Precambrian Research, 
Rose, P.T.S. (1989) The emplacement of the Tay Nappe Scotland. Unpublished PhD thesis, University of Liverpool.

Rose, P.T.S. and Harris, A.L. (2000) Evidence for the lower Palaeozoic age of the Tay Nappe; the timing and nature of Grampian events in the Scottish Highland sector of the Laurentian margin. Journal of the Geological Society, London, 157, 789-98.

Rushton, A.W.A., Owen, A.W., Owens, R.M. and Prigmore, J.K. (1999) British Cambrian and Ordovician stratigraphy, Geological Conservation Review Series No. 18, Joint Nature Conservation Committee, Peterborough.

Russell, M.J., Hall, A.J., Willan, R.C.R., Allison, I., Anderton, R., and Bowes, G. (1984) On the origin of the Aberfeldy celsiantbaritetbase metals deposits, scotland. In Prospecting in areas of glaciated terrain, 1984. Institution of Mining and Metallurgy, London, pp. 159-170.

Ryan, P.D. and Soper, N.J. (2001) Modelling anatexis in intracratonic basins: an example from the Neoproterozoic rocks of the Scottish Highlands. Geological Magazine, 138, 577-588.

Ryan, P.D., Soper, N.J., Snyder, D.B., England, R.W. and Hutton, D.H.W. (1995) The Antrim - Galway Line: a resolution of the Highland Border Fault enigma of the Caledonides of Britain and Ireland. Geological Magazine, 132, 171-184.

Saha, D. (1989) The Caledonian Loch Skerrols Thrust, SW Scotland: Microstructure and Strain. Journal of Structural Geology, 11, 553568 .

Schermerhorn, L.J.G. (1974) Late Precambrian mixtites: glacial and/or non-glacial? American Journal of Science, 274, 673-824.

Schermerhorn, L.J.G. (1975) Tectonic framework of Late Precambrian supposed glacials. In Ice Ages: Ancient and Modern (eds. Wright, A.E. and Moseley, F.), proceedings of the Inter-University Geological Congress (University of Birmingham) (1974), Geological Journal special issue No. 6, 242-247.

Scott, R.A. (1987) Lithostratigraphy, structure and mineralization of the Argyll Group Dalradian near Tyndrum, Scotland. Unpublished PhD thesis, University of Manchester.

Scott, R.A., Pattrick, R.A.D., and Polya, D.A. (1991) Origin of sulphur in metamorphosed stratabound mineralization from the Argyll Group Dalradian of Scotland. Transactions of the Royal Society of Edinburgh: Earth Sciences, Vol. 82, 91-98.

Scott, R.A., Polya, D.A., and Pattrick, R.A.D. (1988) Proximal Cu + Zn exhalites in the Argyll Group Dalradian, Creag Bhocan, Perthshire. Scottish Journal of Geology, Vol. 24, 97-112.

Seranne, M. (1992) Devonian extensional tectonics versus Carboniferous inversion in the northern Orcadian basin. Journal of the Geological Society, London, 149, 27-37.

Shackleton, R. M. 1958. Downward-facing structures of the Highland Border. Quarterly Journal of the Geological Society, London, 113, 361-392.

Shackleton, R.M. (1979) The British Caledonides: comments and summary. 299-304 in The Caledonides of the British Islesreviewed. Harris, A L, Holland, C H, and Leake, B E (editors). Special Publication of the Geological Society of London, No. 8.

Shearman, D.J. and Smith, A.J. (1985) Ikaite, the parent mineral of jarrowite-type pseudomorphs. Proceedings of the Geologists' Association, 96, 305-314. 
Sibson, R.H. (1977) Fault rocks and fault mechanisms. Journal of the Geological Society, London, Vol 133, 191-213.

Simpson, A. and Wedden, D. (1974) Downward-facing structures in the Dalradian Leny Grits on Bute. Scottish Journal of Geology, 10, $257-267$.

Skelton, A.D.L. (1993) Petrological, geochemical and field studies of fluid infiltration during regional metamorphism of the Dalradian of the SW Scottish Highlands. Unpublished PhD thesis, University of Edinburgh.

Skelton, A.D.L., Bickle, M.J. and Graham, C.M. (1997) Fluid-flux and reaction rate from advective-diffusive carbonation of mafic sill margins in the Dalradian, southwest Scottish Highlands. Earth and Planetary Science Letters, 146, 527-539

Skelton, A.D.L., Graham, C.M. and Bickle, M.J. (1995) Lithological and structural constraints on regional 3-D fluid flow patterns during greenschist facies metamorphism of the Dalradian of the SW Highlands. Journal of Petrology, 36, 563-586.

Skevington, D. (1971) Palaeontological evidence bearing on the age of the Dalradian deformation and metamorphism in Ireland and Scotland. Scottish Journal of Geology, Vol. 7, 285-288.

Smallwood, J.R. (2007) Maskelyne's 1774 Schiehallion experiment revisited. Scottish Journal of Geology, Vol. 43, 15-31.

Smith, A.J. and Rast, N. (1958) Sedimentary dykes in the Dalradian of Scotland. Geological Magazine 95, $234-240$.

Smith, C.G., Gallagher, M.J., Coats, J.S. and Parker, M.E. (1984) Detection and general characteristics of stratabound mineralization in the Dalradian of Scotland. Transactions of the Institution of Mining and Metallurgy (Section B: Applied Earth Science), Vol. 93, B125-133.

Smith, C.G., Gallagher, M.J., Grout, A., Coats, J.S., Vickers, B.P., Peachey, D., Pease, S.F., Parker, M.E. and Fortey, N.J. (1988) Stratabound base-metal materialisation in Dalradian rocks near Tyndrum, Scotland. Mineral Reconnaissance Programme Report, British Geological Survey, No. 93.

Smith, C.G., Goodman, S. and Robertson, S. (2002) Geology of the Ballater district. Memoir of the British Geological survey, Sheet 65E (Scotland).

Smith, M., Robertson, S. and Rollin, K.E. (1999) Rift basin architecture and stratigraphical implications for basement-cover relationships in the Neoproterozoic Grampian Group of the Scottish Caledonides. Journal of the Geological Society, London, 156, 11631173 .

Smith, R.A. (1980) The Geology of the Dalradian rocks around Blair Atholl, Central Perthshire, Scotland. Unpublished PhD thesis, University of Liverpool.

Smith, R.A. and Harris, A, L. (1976) The Ballachulish rocks of the Blair Atholl District. Scottish Journal of Geology, Vol. 12, 153157 .

Smith, T.E. (1968) Tectonics in Upper Strathspey, Inverness-shire. Scottish Journal of Geology, 4, 68-84.

Snyder, D.B. and Flack, C.A. (1990) A Caledonian age for reflectors within the mantle lithosphere north and west of Scotland. Tectonics, 9, 903-922.

Soper N.J. (1994) Was Scotland a Vendian RRR junction? Journal of the Geological Society, London, 151, 579-582. 
Soper N.J. (1994) Neoproterozoic sedimentation on the northeast margin of Laurentia and the opening of Iapetus. Geological Magazine, 131, 291-299.

Soper, N.J. and Anderton, R. (1984) Did the Dalradian slides originate as extensional faults? Nature, London, Vol. 307, 357360 .

Soper, N.J. and England, R.W. (1995) Vendian and Riphean rifting in NW Scotland. Journal of the Geological Society, London 152, 11-14.

Soper, N.J. and Evans, J.A., 1997. Discussion on metamorphism and cooling of the NE Dalradian. Journal of the Geological Society, London. $154,357-360$.

Soper N.J. and Hutton D.H.W. (1984) Late Caledonian sinistral displacements in Britain: Implications for a three-plate collision model. Tectonics 3, 781-794.

Soper, N.J., Ryan, P.D. and Dewey, J.F. (1999) Age of the Grampian Orogeny in Scotland and Ireland. Journal of the Geological Society, London 156, 1231-1236.

Soper N.J., Strachan R.A., Holdsworth R.E., Gayer R.A. and O'Greiling, R.O. (1992) Sinistral transpression and the Silurian closure of Iapetus. Journal of the Geological Society, London 149, $871-880$.

Spear, F.S. (1993) Metamorphic phase equilibria and pressuretemperature-time paths. Mineralogical Society of America.

Spencer, A.M. (1971) Late Precambrian glaciation in Scotland. Memoir of the Geological Society of London, No. 6.

Spencer, A.M. (1981) The late Precambrian Port Askaig Tillite in Scotland. In Earth's pre-Pleistocene glacial record (eds. Hambrey, M. J. and Harland, W. B.), pp. 632-636. Cambridge University Press, Cambridge.

Spencer, A.M. (1985) Mechanisms and environments of deposition of Late Precambrian geosynclinal tillites: Scotland and East Greenland. Palaeogeography, Palaeoclimatology and Palaeoecology, $51,143-157$.

Spencer, A.M. and Pitcher, W.S. (1968) Occurrence of the Port Askaig Tillite in north-east Scotland. Proceedings of the Geological Society of London, No. 1650, 195-198.

Spencer, A.M. and Spencer, M. (1972) The Late Precambrian/Lower Cambrian Bonnahaven Dolomite of Islay and its stromatolites. Scottish Journal of Geology, 8, 269-282.

Spray J.G. and Dunning G.R. (1991) A U/Pb age for the Shetland Islands oceanic fragment, Scottish Caledonides: evidence from anatectic plagiogranites in "layer 3" shear zones. Geological Magazine 128, 667-671.

Stephenson, D. (1993) Amphiboles from Dalradian metasedimentary rocks of $\mathrm{NE}$ Scotland: environmental inferences and distinction from meta-igneous amphibolites. Mineralogy and Petrology, Vol. $49,45-62$.

Stephenson, D., Bevins, R.E., Millward, D., Highton, A.J., Parsons, I., Stone, P. and Wadsworth, W.J. (1999) Caledonian Igneous rocks of Great Britain. Geological Conservation Review Series No.17. Joint Nature Conservation Committee, Peterborough. 648pp.

Stephenson, D. and Gould, D. (1995) British regional geology: the Grampian Highlands ( $4^{\text {th }}$ edition). HMSO for the British Geological Survey, London.

Stewart, A.D. (1960) On the sedimentary and metamorphic history of the Torridonian, and the later igneous intrusions of Colonsay and Oronsay. Unpublished PhD thesis, University of Liverpool. 
Stewart, A.D. (1962) On the Torridonian sediments of Colonsay and their relationship to the main outcrop in north-west Scotland. Liverpool and Manchester Geological Journal 3, 121-156.

Stewart, A.D. (1969) Torridonian rocks of Scotland reviewed. In Kay, M. (ed.) North Atlantic-Geology and Continental Drift, a symposium. Memoir of the American Association of Petroleum Geologists 12, 595-608.

Stewart, A.D. (1975) 'Torridonian' rocks of western Scotland. In: A correlation of Precambrian rocks in the British Isles (eds. Harris, A. L., Shackleton, R. M., Watson, J.V., Downie, C., Harland, W. B. and Moorbath, S.) Geological Society, London, Special Report, 6, 43-51.

Stewart, A.D. and Hackman, B.D. (1973) Precambrian sediments of Islay. Scottish Journal of Geology, 9, 185-201.

Stewart, M., Strachan, R.A. and Holdsworth, R.E. (1999) Structure and early kinematic history of the Great Glen fault zone, Scotland. Tectonics 18, 326-342.

Stewart, M., Strachan, R.A., Martin, M.W. and Holdsworth, R.E. (2001) Constraints on early sinistral displacements along the Great Glen Fault Zone, Scotland; structural setting, U-Pb geochronology and emplacement of the syn-tectonic clunes Tonalite. Journal of the Geological Society, London 158, 821-830.

Stoker, M.S., Howe, J.A. and Stoker, S.J. (1999) Late Vendian?Cambrian glacially influenced deep-water sedimentation, Macduff Slate Formation (Dalradian), $\mathrm{NE}$ Scotland. Journal of the Geological Society, London, 156, 55-61.

Stone, M. (1957) The Aberfoyle Anticline, Callander, Perthshire. Geological Magazine, 94, 265-276.

Stone, P., Plant, J.A., Mendum, J.R. and Green, P.M. (1999) A regional geochemical assessment of some terrane relationships in the British Caledonides. Scottish Journal of Geology, 35, 145-156.

Strachan, R.A. (2000) The Grampian Orogeny: Mid-Ordovician arccontinent collision along the Laurentian margin of Iapetus. In: Woodcock, N.H. and Strachan, R.A. (eds) Geological History of Britain and Ireland. Blackwell Science Ltd, 88-106.

Strachan, R.A., Harris, A.L., Fettes D.J. and Smith, M. (2002) The Northern Highland and Grampian terranes. In: Trewin N. H. (ed.) The Geology of Scotland. (4th edition) The Geological Society, London, pp. 81-148.

Strachan, R.A. and Holdsworth, R.E. (2000) Proterozoic sedimentation, orogenesis and magmatism on the Laurentian Craton (2700-750 Ma). In: Geological history of Great Britain and Ireland (edited by Woodcock, N. and Strachan, R. A.) Blackwell Science. Oxford, 52-72.

Stringer, P.J. (1957) Polyphase deformation in the Upper Dalradian rocks of the Southern Highlands of Scotland. Unpublished PhD thesis, University of Liverpool.

Stupavsky, M., Symons, D.T.A. and Gravenor, C.P. (1982) Evidence for metamorphic remagnetisation of the upper Precambrian tillite in the Dalradian Supergroup of Scotland. Transactions of the Royal Society of Edinburgh, 73, 59-65.

Sturt, B.A. (1959) Studies in the metamorphic rocks of the Loch Tummel district, Perthshire. Unpublished PhD thesis, University of Wales, Aberystwyth.

Sturt, B.A. (1961) The geological structure of the area south of Loch Tummel. Quarterly Journal of the Geological society of London, Vol. 117, 131-156. 
Sturt, B.A. and Harris, A.L. (1961) The metamorphic history of the Loch Tummel area. Liverpool and Manchester Geological Journal, Vol. 2, 689-711.

Sturt, B.A., Ramsay, D.M., Pringle, I.R. and Teggin, D.E. (1977) Precambrian gneisses in the Dalradian sequence of NE Scotland. Journal of the Geological Society of London, Vol. 134, $41-44$.

Sutton, J. and Watson, J.V. (1954) Ice-borne boulders in the Macduff Group of the Dalradian of Banffshire. Geological Magazine, Vol. 91, 391-398.

Sutton, J. and Watson, J.V. (1955) The deposition of the Upper Dalradian rocks of the Banffshire coast. Proceedings of the Geologists' Association, Vol. 66, 101-133.

Sutton, J. and Watson, J.V. (1956) The Boyndie syncline of the Dalradian of the Banffshire coast. Quarterly Journal of the Geological Society of London, Vol. 112, 103-130.

Tanner, P. W. G. 1992. Rosneath Peninsula and Loch Long. In Geological excursions around Glasgow and Girvan (eds. Lawson, $J$. D. and Weedon, D. S.), pp. 159-185. Geological Society of Glasgow.

Tanner, P. W. G. 1995. New evidence that the Lower Cambrian Leny Limestone at Callander, Perthshire, belongs to the Dalradian Supergroup, and a reassessment of the 'exotic' status of the Highland Border Complex. Geological Magazine, 132, 473-483.

Tanner, P. W. G. 1996. Significance of the early fabric in the contact metamorphic aureole of the 590 Ma Ben Vuirich Granite, Perthshire, Scotland. Geological Magazine, 133, 683-695.

Tanner, P. W. G. 1997. The Highland Border controversy: Reply to a Discussion of 'New evidence that the Lower Cambrian Leny Limestone at Callander, Perthshire, belongs to the Dalradian Supergroup, and a reassessment of the 'exotic' status of the Highland Border Complex'. Geological Magazine, 134, 565-570.

Tanner, P. W. G. 1998a. Interstratal dewatering origin for polygonal patterns of sand-filled cracks: a case study from Late Proterozoic metasediments of Islay, Scotland. Sedimentology, 45, $71-89$.

Tanner, P W G. 1998b. Age of the Grampian event: Reply to a Discussion of 'New evidence that the Lower Cambrian Leny Limestone at Callander, Perthshire belongs to the Dalradian Supergroup, and a reassessment of the 'exotic' status of the Highland Border Complex'. Geological Magazine, Vol. 135, 575-579.

Tanner, P. W. G. 2005. Discussion on evidence for a major Neoproterozoic orogenic unconformity within the Dalradian Supergroup of NW Ireland. Journal of the Geological Society, London, 162, 221-224.

Tanner, P.W.G. 2007. The role of the Highland Border Ophiolite in the $470 \mathrm{Ma}$ Grampian Event, Scotland. Geological Magazine Vol. $144,597-602$.

Tanner, P.W.G. 2008. Tectonic significance of the Highland Boundary Fault. Journal of the Geological Society, London Vol. 165, 915921.

Tanner, P.W.G. and Bluck, B.J. (2011) Discussion of 'The Highland Boundary Fault and the Highland Boundary Complex' by B.J. Bluck Scottish Journal of Geology 46, 113-124. Scottish Journal of Geolgy, 47, 89-93. 
Tanner, P. W. G. and BLUCK, B. J. 1999. Current controversies in the Caledonides. Journal of the Geological Society, London, 156, 1137-1141.

Tanner, P. W. G. and Evans, J. A. 2003. Late Precambrian U-Pb titanite age for peak regional metamorphism and deformation (Knoydartian Orogeny) in the western Moine, Scotland. Journal of the Geological Society, London 160, 555-564.

Tanner, P. W. G. and Leslie, A. G. 1994. A pre-D2 age for the 590 Ma Ben Vuirich Granite in the Dalradian of Scotland. Journal of the Geological Society, London, 151, 209-212.

Tanner P. W. G., Leslie A. G. and Gillespie M.R. 2006. Structural setting and petrogenesis of a rift-related intrusion: the Ben Vuirich Granite of the Grampian Highlands, Scotland. Scottish Journal of Geology, Vol. 42, 113-136.

Tanner, P. W. G. and Pringle, M. 1999. Testing for a terrane boundary within Neoproterozoic (Dalradian) to Cambrian siliceous turbidites at Callander, Perthshire, Scotland. Journal of the Geological Society, London, 156, 1205-1216.

Tanner, P.W.G. and Sutherland, S. 2007. The Highland Border Complex, Scotland: a paradox resolved. Journal of the Geological Society, London, 164, 111-116.

Tannner, P.W.G. and Thomas, P.R. (2010) Major nappe-like D2 folds in the Dalradian rocks of the Beinn Udlaidh area, Central Highlands, Scotland. Earth and Environmental Science Transactions of the Royal Society of Edinburgh. 100, 371-389.

Temperley, S. (1990). The Late Proterozoic to Early Palaeozoic geology of the Glen Banchor area in the Monadhliath Mountains of Scotland, with particular reference to deformation in Knoydartian shear zones and the Caledonian Central Highland steep belt. Unpublished PhD thesis, University of Hull.

Thomas, C W. 1989. Application of geochemistry to the stratigraphic correlation of Appin and Argyll Group carbonate rocks from the Dalradian of northeast Scotland. Journal of the Geological Society of London, Vol. 146, 631-647.

Thomas, C. W. 1993. Sources of Rare Earth elements in Appin Group limestones, Dalradian, north-east Scotland. Mineralogy and Petrology Vol. 49, 27-44.

Thomas, C.W. (1995). The geochemistry of metacarbonate rocks from the Monadhliath Project area. British Geological Survey Technical Report. WA/95/40/R.

Thomas, C. W. (1999). The isotope Geochemistry and Petrology of Dalradian Metacarbonate Rocks, Unpublished PhD thesis, University of Edinburgh.

Thomas, C.W. and Aitchison (1998). Application of logratios to the statistical analysis of the geochemistry of metamorphosed limestones from the Northeast and Central Highlands of Scotland: the case for Appin Group correlations. British Geological Survey Technical Report, WA/98/03.

Thomas, C W, Aitken, A M, Pickett, E P, Mendum, J R, Hyslop, E K, and Petterson, M.P. in press. Geology of the Aberfoyle District. Sheet Description for the British Geological Survey, 1:50 000 Series sheet 38E (Scotland).

Thomas, C. W., Graham, C. M., Ellam, R.M. and Fallick, A. E. $(2004) .{ }^{87} \mathrm{Sr} /{ }^{8} 6 \mathrm{Sr}$ chemostratigraphy of Neoproterozoic Dalradian limestones of Scotland: constraints on depositional ages and timescales. Journal of the Geological Society, London 161, 223243. 
Thomas, C.W., Smith, M. and Robertson, S. (1997). The geochemistry of Dalradian metacarbonate rocks from the Schiehallion District and Blargie, Laggan: implications for stratigraphical correlations in the Geal Charn-Ossian Steep Belt. British Geological Survey Technical Report, WA/97/81.

Thomas, P R. 1965. The structure and metamorphism of the Moinian rocks in Glen Garry, Glen Tilt, and adjacent areas of Scotland. Unpublished PhD thesis, University of Liverpool.

Thomas, P R. 1979. New evidence for a Central Highland Root Zone. 205-211 in The Caledonides of the British Isles -Reviewed. Harris, A L, Holland, $\mathrm{C}$ H, and Leake, B E (editors). Special Publication of the Geological Society, No. 8.

Thomas, P R. 1980. The stratigraphy and structure of the Moine rocks north of the Schiehallion Complex, Scotland. Journal of the Geological Society of London, Vol. 137, 469-482.

Thomas, P R. 1988. A9 road section-Blair Atholl to Newtonmore. 39-50 in An excursion guide to the Moine geology of the Scottish Highlands. Allison, I, May, F, and Strachan, R A (editors). (Edinburgh: Scottish Academic Press for Edinburgh Geological Society and Geological Society of Glasgow.)

Thomas, P R, and Treagus, J E. 1968. The stratigraphy and structure of the Glen Orchy area, Argyllshire, Scotland. Scottish Journal of Geology, Vol. 4, 121-134.

Thomson, J. 1877. On the geology of the Island of Islay. Transactions of the Geological Society of Glasgow, 5, 200-222.

Tilley, C.E. (1925) A preliminary survey of metamorphic zones in the southern Highlands of Scotland. Quarterly Journal of the Geological Society of London, Vol. 81, 100-110.

Tollo R. P., Aleinikoff J. N., Bartholomew M. J. and Rankin D. W. 2004. Neoproterozoic A-type granitoids of the central and southern Appalachians: intraplate magmatism associated with episodic rifting of the Rodinian supercontinent. Precambrian Research, 128, 3-38.

Torsvik, T. H., Smethurst, M. A., Meert, J. G., Van der Voo, R., McKerrow, W. S., Brasier, M. D., Sturt, B. A. and Walderhaug, H. J. 1996. Continental break-up and collision in the Neoproterozoic and Palaeozoic-a tale of Baltica and Laurentia. Earth Science Reviews 40, 229-258.

Treagus, J. E. 1964a. The structural and metamorphic history of an area of Moine and Dalradian rocks south of Loch Rannoch, Perthshire. Unpublished PhD thesis, University of Liverpool.

Treagus, J E. 1964b. Notes on the structure of the Ben Lawers Synform. Geological Magazine, Vol. 101, 260-270.

Treagus, J.E. (1969). The Kinlochlaggan Boulder Bed. Proceedings of the Geological Society of London, 1654, 55-60.

Treagus, J E. 1974. A structural cross-section of the Moine and Dalradian rocks of the Kinlochleven area, Scotland. Journal of the Geological Society of London, Vol. 130, 525-544.

Treagus, J.E. (1981). The Lower Dalradian Kinlochlaggan Boulder Bed, Central Scotland. In: Earth's pre-Pleistocene glacial record. (editors. Hambrey, J.M. and Harland, W.B.), Cambridge University Press, 637-639.

Treagus, J E. 1987. The structural evolution of the Dalradian of the Central Highlands of Scotland. Transactions of the Royal Society of Edinburgh: Earth Sciences, Vol. 78, 1-15.

Treagus, J E. 1991. Fault displacements in the Dalradian of the Central Highlands. Scottish Journal of Geology, Vol. 27, 135-145. 
Treagus, J. E. (editor). 1992. Caledonian Structures in Britain South of the Midland Valley, Geological Conservation Review Series No. 3. London: Chapman and Hall.

Treagus, J.E. (1997) Discussion on a late Vendian age for the Kinlochlaggan Boulder bed (Dalradian). Journal of the Geological Society, London, 154, 917-919.

Treagus, J E. 1999. A structural reinterpretation of the Tummel Belt and a transpressional model of evolution of the Tay Nappe in the Central Highlands of Scotland. Geological Magazine, Vol. 136, Pt 6, 643-660.

Treagus, J. E. 2000. The Solid Geology of the Schiehallion District. Memoir of the British Geological Survey. Sheet 55W (Scotland).

Treagus, J.E. 2009. The Dalradian of Scotland. Geologists' Association Guide No. 67. 202pp.

Treagus, J E, and King, G. 1978. A complete Lower Dalradian succession in the Schiehallion district, central Perthshire. Scottish Journal of Geology, Vol. 14, 157-166.

Treagus, J E, Pattrick, R A D, and Curtis, S F. 1999. Movement and mineralization in the Tyndrum fault zone, Scotland and its regional significance. Journal of the Geological Society, London, Vol. 156, 591-604.

Treagus, J E. and Roberts, J L. 1981. The Boyndie Syncline, a D1 structure in the Dalradian of Scotland. Geological Journal, Vol. $16,125-135$.

Treagus, J E, Talbot, C J, and Stringer, P. 1972. Downward-facing structures in the Birnam Slates, Dunkeld, Perthshire. Geological Journal, Vol. 8, 125-128.

Treagus, J E, and Treagus, S H. 1971. The structures of the Ardsheal peninsula, their age and regional significance. Geological Journal, Vol. 7, 335-346.

Treagus, J E, and Treagus, S H. 1981. Folds and the strain ellipsoid; a general model. Journal of Structural Geology, Vol. 3, Pt 1, 1-17.

Trewin, N. H. (editor) 2002. The Geology of Scotland. (4 $4^{\text {th }}$ edition) The Geological Society, London. 576 pp.

Trewin, N.H., Kneller, B.C. and Gillen, C. (1987) Excursion Guide to the Geology of the Aberdeen area. (Edinburgh: Scottish Academic Press, for Geological Society of Aberdeen).

Trewin, N.H. and Rollin, K. 2002. In: Trewin, N.H. (ed.) The geology of Scotland.(4 ${ }^{\text {th }}$ edition) The Geological Society, London, $1-25$.

Trewin, N.H. and Thirlwall, M.F. 2002. Old Red Sandstone. In: Trewin N. H. (ed.) The Geology of Scotland. (4 ${ }^{\text {th }}$ edition) The Geological Society, London, pp. 213-249.

Tyrrell, G.W. 1921. Some points in petrographic nomenclature. Geological Magazine Vol. 58, 494-502.

Underhill, J.R. 1993. Discussion on the location and history of the Walls Boundary fault and Moine thrust north and south of Shetland. Journal of the Geological Society, London, 150, 1003-1008.

Upton, P.S., 1983. A stratigraphic, structural and metamorphic study of the lower and middle Dalradian, between Braemar and the Spittal of Glenshee, N.E. Scotland. Unpublished PhD thesis, University of Manchester. 
Upton, P S. 1986. A structural cross-section of the Moine and Dalradian rocks of the Braemar area. Report of the British Geological Survey, Vol. 17, No. 1, 9-19.

Van Breemen, O., Aftalion, M. and Johnson, M. R. 1979. Age of the Loch Borrolan complex, Assynt and late movements along the Moine Thrust Zone. Journal of the Geological Society of London 16, 489495 .

Van de Kamp, P.C. 1968. Origins of para-amphibolites. Unpublished PhD thesis, University of Bristol.

Van de Kamp, P C. 1970. The Green Beds of the Scottish Dalradian Series: geochemistry, origin and metamorphism of mafic sediments. Journal of Geology, Vol. 78, 281-303.

Van Staal, C. R., Dewey, J. F., McKerrow, W. S. and MacNiocaill, C. 1998. The Cambrian-Silurian tectonic evolution of the northern Appalachians and British Caledonides: history of a complex, southwest Pacific-type segment of Iapetus. In: Lyell: the Present is in the Past (edited by Blundell, D. J. and Scott, A. C.). Geological Society, London, Special Publication, 143, 199-242.

Vance, D., Strachan, R. A. and Jones, K. A. 1998. Extensional versus compressional settings for metamorphism: Garnet chronometry and pressure-temperature-time histories in the Moine Supergroup, northwest Scotland. Geology 26, 927-930.

Viete, D.R., Forster, M.A. and Lister, G.S. (2011) The nature and origin of the Barrovian metamorphism, Scotland: ${ }^{40} \mathrm{Ar} /{ }^{39} \mathrm{Ar}$ apparent age patterns and the duration of metamorphism in the biotite zone. Journal of the Geological Society, London, 168, 133-146.

Viete, D.R., Hermann, J., Lister, G.S. and Stenhouse, I.R. (2011) The nature and origin of the Barrovian metamorphism, Scotland: diffusion length scales in garnet and inferred thermal time scales. Journal of the Geological Society, London, 168, 115-132.

Viete, D.R., Richards, S.W., Lister, G.S., Oliver, G.J.H. and Banks, G.J. (2010) Lithospheric-scale extension during Grampian orogenesis in Scotland. in Law, R.D., Butler, R.W.H., Holdsworth, R.E., Krabbendam, M. and Strachan, R.A. (editors) Continental Tectonics and Mountain Building: the Legacy of Peach and Horne. Geological Society, London, Special Publications, 335, 121-160.

Viljoen, M. J and Viljoen, R. P. 1969. Evidence for the existence of a mobile extrusive peridotite magma from the Komati Formation of the Onverwacht Group. Geological Society of South Africa, Special Publication No. 2, 87-112.

Vogt, T. 1930. On the chronological order of deposition in the Highlands. Geological Magazine, 67, 68-76.

Voll, G. 1960. New work on Petrofabrics. Liverpool and Manchester Geological Journal, 2, 503-567.

Voll, G. 1964. Deckenbau und fazies im Schottischen Dalradian. Geologische Rundschau, Vol. 53, 590-612.

Vorhies, S.H. and Ague, J.J. (2011) Pressure - temperature evolution and thermal regimes in the Barrovian zones, Scotland. Journal of the Geological Society, London, 168, 1147-1166.

Wain, A. (1999). The petrography and metamorphic evolution of metabasic rocks from the Lower Dalradian of the Central Highlands area. British Geological Survey Technical Report No. WA/99/13.

Watkins, K.P. 1982. The structure and metamorphism of the Balquhidder-Crianlarich region of the Scottish Dalradian. Unpublished PhD thesis, University of Cambridge. 
Watkins, K P. 1983. Petrogenesis of Dalradian albite porphyroblast schists. Journal of the Geological Society of London, Vol. 140, 601-618.

Watkins, K P. 1984. The structure of the Balquhidder-Crianlarich region of the Scottish Dalradian and its relation to the Barrovian garnet isograd surface. Scottish Journal of Geology, Vol. 20, 5364 .

Watkins, K.P. 1985. Geothermometry and geobarometry of inverted metamorphic zones in the $W$. Central Scottish Dalradian. Journal of the Geological Society of London, 142, 157-165.

Watson, J. V. 1984. The ending of the Caledonian Orogeny in Scotland. Journal of the Geological Society of London 141, 193214 .

Weiss, L E, and McIntyre, D B. 1957. Structural geometry of Dalradian rocks at Loch Leven, Scottish Highlands. Journal of Geology, Vol. 65, 575-602.

Wells, P. R. A. and Richardson, S. W. 1979. Thermal evolution of metamorphic rocks in the Central Highlands of Scotland. In Harris, A. L., Holland, C. H. and Leake, B. E. (editors), The Caledonides of the British Isles-reviewed. Geological Society of London Special Publication No. 8, published by Scottish Academic Press, Edinburgh, 339-344.

Whalen J. B., Currie J. L. and Chappell B. W. 1987. A-type granites: geochemical characteristics, discrimination and petrogenesis. Contributions to Mineralogy and Petrology, 95, 407419.

Whitten, E H T. 1959. A study of two directions of folding; the structural geology of the Monadhliath and mid-Strathspey. Journal of Geology, Vol. 67, 14-47.

Whittles, K.H. 1981. The geology and geochemistry of the area west of Loch Killin, Inverness-shire. Unpublished PhD thesis, University of Keele.

Wilkinson, S. B. 1907. The geology of Islay. Memoirs of the Geological Survey of Scotland, Sheets 19 and 27, and parts of 20.

Willan, R. C. R., and Coleman, M L. 1983. Sulphur isotope study of the Aberfeldy barite, zinc, lead deposit and minor sulfide mineralization in the Dalradian metamorphic terrain, Scotland. Economic Geology, Vol. 78, 1619-1656.

Williamson, D. H., 1953. Petrology of chloritoid and staurolite rocks north of Stonehaven, Kincardineshire. Geological Magazine, $90,353-361$.

Williamson, $W$ O. 1935. The composite gneiss and contaminated granodiorite of Glen Shee, Perthshire. Quarterly Journal of the Geological Society of London, Vol. 91, 382-422.

Wilson, J.R. and Leake, B.E. 1972. The petrochemistry of the epidiorites of the Tayvallich Peninsula, North Knapdale, Argyllshire. Scottish Journal of Geology 8, 215-252.

Winchester, J.A. 1974. The zonal pattern of regional metamorphism in the Scottish Caledonides. Journal of the Geological Society of London, 130, 509-24.

Winchester, J.A. and Glover, B.W. (1988). The Grampian Group, Scotland. In: Later Proterozoic stratigraphy of the Northern Atlantic region. (editor Winchester, J.A.). Blackie, Glasgow and London, 146-161.

Winchester, J.A. and Glover, B.W. (1991). Grampian Group: PitlochryLoch Laggan-Glen Spean. In: The Late Precambrian Geology of the Scottish Highlands and Islands. (editors Hambrey, M.J., Fairchild, 
I.J., Glover, B.W., Stewart, A.D., Treagus, J.E. and Winchester, J.A.). Geologists' Association Guide No. 44, 66-85.

Wiseman, J D H. 1934. The central and south-west Highland epidiorites: a study in progressive metamorphism. Quarterly Journal of the Geological Society of London, Vol. 90, 354-417.

Wood, D.S. 1964. Some structures in the Dalradian pillow lavas of the Tayvallich Peninsula, Argyll. Geological Magazine, 101, 481

Woodcock, N. and Strachan, R. 2000. Geological History of Britain and Ireland. Blackwell Science, Oxford.

Wright, A.E. 1976. Alternating subduction direction and the evolution of the Atlantic Caledonides Nature, London 264, 156.

Wright, A. E. 1988. 15. The Appin Group. In Later Proterozoic Stratigraphy of the Northern Atlantic Regions (editor Winchester, J. A.), pp. 177-199. Blackie.

Yardley B. W. D. (1989) An introduction to metamorphic petrology. Longman, Harlow.

Yardley, B.W.D. and Valley, J.W. 1997. The petrologic case for a dry lower crust. Journal of Geophysical Research, 106 B6, 1217312185 .

Zeh, A. and Millar, I. L. 2001. Metamorphic evolution of garnetepidote-biotite gneiss from the Moine Supergroup, Scotland, and geotectonic implications. Journal of Petrology 42, 529-554.

Zenk, M. and Schulz, B. 2004. Zoned Ca-amphiboles and related P-T evolution in metabasites from the classical Barrovian metamorphic zones in Scotland. Mineralogical Magazine, 68, 769-786.

Figure 1 Map of the Central Grampian Highlands, showing Dalradian subgroups, major structures including the Boundary Slide and locations of GCR sites. Only areas described in this regional paper are ornamented. * On the limbs of the late Errochty Synform, to the north of Schiehallion, highly attenuated condensed sequences of the Lochaber and Ballachulish subgroups, too thin to be shown at this scale, are present in the Boundary slide-zone.

GCR sites: 1, River Leven Section, 2 Nathrach, 3 Rubha Cladaich, 4 Tom Meadhoin and Doire Ban, 5 Stob Ban, 6 St John's Church, Loch Leven, 7 Onich Dry River Gorge and Onich Shore Section, 8 Ardsheal Peninsula, 9 South Coast, Lismore Island, 10 Camas Nathais, 11 Port Selma, Ardmucknish, 12 River Orchy, 13 A9 Road Cuttings and River Garry Gorge, 14 Creag nan Caisean-Meall Reamhar, 15 Meall Dail Chealach, 16 Strath Fionan, 17 Tempar Burn, 18 Allt Druidhe, 19 Slatich, 20 Ben Lawers, 21 Craig an Chanaich to Frenich Burn, 22 Auchtertyre, 23 Ben Oss.

Faults: BBF Bridge of Balgie Fault, ELF Ericht-Laidon Fault, GGF Great Glen Fault, LTF Loch Tay Fault, TF Tyndrum Fault.

F1 and F2 folds: AS Appin/Cuil Bay Syncline, AHA Airds Hill Anticline, BCS Beinn Chuirn Synform, BDS Beinn Donn Syncline, BLA Ben Lui Antiform, BSA Beinn Sgluich Anticline, BUS Beinn Udlaidh Syncline, BWA Blackwater Antiform/Treig Syncline, BWS Blackwater Synform, CA Clunes Antiform, IA Inverlair Antiform, KA Kinlochleven Antiform, LDS Loch Dochard Syncline, MRS Meall Reamhar Synform, RA Ruskich Antiform, SBS Stob Ban Synform. 
F3, F4 and later folds: BA Bohespic Antiform, BLS Ben Lawers Synform, DD Drumochter Dome, ES Errochty Synform, TM Trinafour Monoform.

Figure 2 Comparison of Dalradian successions in the Loch Leven and Schiehallion (Strath Fionan) areas.

\section{Figure 3}

(a) Map of the Loch Leven area, showing outcrops of the main stratigraphical units, major structures and locations of GCR sites. BS Ballachulish Syncline, BaSl Ballachulish Slide, FWSl Fort William Slide

(b) Diagrammatic profile of the area shown in (a), looking upplunge of $F 1$ folds and showing position of GCR sites. Key, abbreviations and horizontal scale as in (a).

\section{Figure 4}

(a) Map of the Schiehallion-Loch Tay area, showing outcrops of the main stratigraphical units, major structures and locations of GCR sites.

(b) Cross-section of the Schiehallion-Loch Tay area, showing positions of GCR sites. Key, abbreviations and horizontal scale as in (a).

Figure 5 Map of the River Leven section east of Kinlochleven.

Figure 6 Near-vertical bedding in the Binnein Quartzite, on a horizontal surface in the River Leven at NN 1910 6186; the crosssets young to the west (top of photograph). Coin is $20 \mathrm{~mm}$ diameter. (Photo: J.E. Treagus.)

Figure 7 Map of the area around the Nathrach GCR site, showing the boundary between the Binnein Quartzite and the Binnein Schist on the two limbs of the Fl downward-facing Mamore syncline. At localities A, B and C, relations between bedding and the three cleavages are shown, as appropriate. The relation of bedding to the direction of younging is shown at localities along the boundary as well as at localities $A$ and $C$, within the Binnein Schists.

Figure 8 Thinly-bedded quartzites and semipelites in the Binnein Schists, tightly folded by F2 folds that plunge steeply to the north-east at locality A, Figure 7 in the Nathrach GCR site. Coin is $25 \mathrm{~mm}$ diameter. (Photo: J.E. Treagus.)

Figure 9 Semipelites interbedded in the Binnein Quartzite, as seen on a surface sloping gently to the south-east (bottom right) at locality B, Figure 7 in the Nathrach GCR site. Cross-bedding near the top left corner youngs to the south-east and faces down on the axial-planar fabric of the minor folds; these folds, which are of D1 age, plunge at $40^{\circ}$ to the north-east and verge to the northeast. Not clear in the photograph is the s2 crenulation cleavage, which cross-cuts the Fl folds parallel to the length of the pencil. Pencil is $15 \mathrm{~cm}$ long. (Photo: J.E. Treagus.) 
Figure 10 Map of the coastal section at the Rubha Cladaich GCR site, showing the outcrops of the Glen coe Quartzite, Binnein Schists and Binnein Quartzite. Principal exposures are outlined.

Figure 11 D2 folds and cleavage in the Binnein Schists at the Rubha Cladaich GCR site. F1 folds can be seen, for instance, at the tip of the pencil. Pencil is $10 \mathrm{~cm}$ long. (Photo: J.E. Treagus.)

Figure 12 Regional geological context of the Tom Meadhoin and Doire Ban GCR site. After Roberts and Treagus (1977b, figure 5).

Figure 13 Map of the Stob Ban GCR site. After Roberts and Treagus (1977b, figure 5).

Figure 14 Stob Ban (left) viewed from the east, showing the Binnein Quartzite dipping to the north-west (away from the camera) on the south-east limb of the stob Ban Synform. In the centre, the area of the Stob Ban GCR site, beds of Leven Schists and Ballachulish Limestone dip to the south-east on the north-west limb of the synform. (Photo: D. Stephenson, BGS No. P 726592.)

Figure 15 Map of the Loch Leven shore section at St John's church after Bailey (1960).

Figure 16 View looking north-east along the outcrop of the Ballachulish Slide on the shore of Loch Leven, near St John's church. The slide occurs beneath the hammer shaft and can be traced along the black dotted line. To its right is the Ballachulish Limestone; immediately left of the hammer, and for about one metre beyond, are a few centimetres of quartzitic Leven Schists; the remainder of the exposure left of the slide is a NEtrending dyke. Hammer shaft is $30 \mathrm{~cm}$ long. (Photo: J.E. Treagus.)

Figure 17 Map of the Onich Shore Section and the south-west end of the Onich Dry River Gorge GCR sites. Areas outlined by dotted lines are exposures discussed in the text, showing typical measurements of bedding (with direction of younging where appropriate) and plunge (and vergence where appropriate) of F1 minor folds.

Figure 18 Generalized structural profile of the F1 Appin Syncline for the area containing the Onich Dry River Gorge, Onich Shore Section and Ardsheal Peninsula GCR sites, looking up-plunge to the north-east at about $25^{\circ}$. Use has been made of data from the Onich shore section as well as the profile drawn of the Ardsheal area by Treagus and Treagus (1971, figure 2). Data from localities 1-5 of the Ardsheal Peninsula GCR site are shown in the top left corner of the profile.

\section{Figure 19}

(a) Cross-sets, younging to the north-west (top left) on a horizontal surface of near vertical-dipping Appin Quartzite at Caigean Mor (NN 0437 6105) on the Onich shore section. Lens cap (top left) is $4 \mathrm{~cm}$ diameter.

(b) View to the north-east of SE-verging $\mathrm{F} 1$ folds of a $10 \mathrm{~cm}-$ thick limestone bed, and of thinner adjacent beds, in the Appin 
Phyllite on the Onich shore section at NN $036612,300 \mathrm{~m}$ SW of the school. Coin (centre) is $30 \mathrm{~mm}$ in diameter.

(Photos: J.E. Treagus.)

Figure 20 Map of the Appin Syncline on the Ardsheal Peninsula. Numbers relate to localities discussed in the text. After Treagus and Treagus (1971).

\section{Figure 21}

(a) Bedding in the Cuil Bay Slates shows upward grading, crossed by upright S1 cleavage. View to the south-west, down the plunge of a F1 fold hinge from NM 972 554, Rubha Beag, Ardsheal Peninsula. Lens cap is $5 \mathrm{~cm}$ in diameter.

(b) F1 folds, verging north-west and plunging gently to the south-west in phyllitic semipelites and psammites near the top of the Appin Quartzite on Rubha Mor, Ardsheal Peninsula (NM 9640 5565). The fanning S1 cleavage can be seen in the semipelite bed in the centre. Figures for scale.

(Photos: J.E. Treagus.)

Figure 22 Map of southern Lismore Island, showing the 'units' of the Lismore Limestone Formation and sedimentary cycles within the Middle unit as mapped by Hickman $(1975,1978)$. The traces of the major folds are also shown: A and B form a major F2 fold-pair, C is a major F1 syncline. The cross-section (after Hickman, 1978) illustrates the major folds and the relation of the (schematic) vergence of the F2 minor folds.

Figure 23 Open F2 minor folds, verging north-west in the Lismore Limestone Formation south-west of Miller's Port (NM 812 372); view to the south-west. Figure is $1.5 \mathrm{~m}$ tall. (Photo: J.E. Treagus.)

Figure 24 Map of the Lochnell Peninsula and adjoining area, north of Oban, modified from BGS 1:50 000 Sheet 45E (Connel). It shows the regional setting of both the Camas Nathais and Port Selma, Ardmucknish GCR sites (labelled inset boxes), and the line of the Benderloch Slide.

Figure 25 Detailed map of an area at the head of Camas Nathais (see inset on Figure 24), based upon a survey by P.W.G. Tanner using GPS for location. The irregularly shaped Palaeogene dykes and sheets provide a guide to location on this featureless rock platform. The map shows the relationship of the rock sequence and structure in the hanging wall of the Benderloch Slide (S), to those in the footwall.

Figure 26 The Benderloch Slide at Camas Nathais, as seen looking north from locality 1, Figure 25. The slide-plane dips steeply to the north-west and separates graphitic pelite ( $g$ ) above, from a strongly boudinaged and disrupted unit of orange-weathering dolostone (d) below. To the right of and beneath the dolostone is the intensely fractured Baravullin Quartzite (q) .

Inset: Lineations in the graphitic pelite just above the slide, as seen looking in the direction of the arrow in the main photo. Two sets of steeply plunging lineations lie in the plane of the phyllitic cleavage The lineation plunging steeply to the left 
(north) is the stretching lineation associated with the slide movement, and it is crossed by later crenulation lineations and kink bands plunging to the right (south).

(Photos: P.W.G. Tanner.)

Figure 27 Map of the Port Selma, Ardmucknish area showing the distribution of breccia (B1-5) and interbreccia (IB3, IB4) beds belonging to the Selma Breccia, and their relationship to the selma Black Slates (modified from Litherland, 1982). Structural interpretation by P.W.G. Tanner.

Figure 28 The Selma Breccia as seen on the coast at locality 1, Figure 27, showing the variations in clast type and shape within part of breccia units B1-B3 (m, mudstone raft). The direction of view is to the south-east, with the longest dimensions of the clasts being generally aligned parallel to the NE-trending slaty cleavage. (Photo: P.W.G. Tanner.)

Figure 29 Map of the closure of the F2 Beinn Udlaidh Syncline in Glen orchy. The curved axial trace of this fold is due to the intersection of the gently dipping axial surface with the irregular topography, and does not reflect the curvilinear hinge as described in the text or later deformation. Equal-area stereographic projections for some of the structural data are shown. Stereoplot (a) shows the poles to the axial planes of minor folds related to the syncline, together with their computed mean orientation as a great circle (solid line). Stereoplot (b) shows the orientations of stretching lineations (solid triangles; $\mathrm{N}=41$ ) and minor fold hinges (open circles; $N=107)$, related to the major syncline. The solid line represents the computed best-fit plane containing the fold hinges.

Figure 30 Z-shaped vergence shown by main-phase minor folds, which plunge to the south on the upper limb of the F2 Beinn Udlaidh Syncline in the River orchy. The structures are seen looking due south from the dam at locality 1, Figure 29, during low-water conditions. The hammer shaft is $78 \mathrm{~cm}$ long. (Photo: P.W.G. Tanner.)

Figure 31 Stacked fold hinges of minor folds ('fold mullions') with neutral vergence in the hinge-zone of the F2 Beinn Udlaidh Syncline in the River orchy at locality 2, Figure 29. The structures are viewed from the south-east, and the hammer shaft is $78 \mathrm{~cm}$ long. (Photo: P.W.G. Tanner.)

Figure 32 The major structures of Glen Garry depicted in three dimensions and showing the localities 1-7 that are described in the text. Below is a map of the Glen Garry section showing the A9 road, the River Garry and the positions of the numbered localities. Adapted from Thomas (1988, figure 1.2).

Figure 33 Cross-bedded laminated schistose psammites at the Stalcair cut on the A9 road (locality 1 ). The beds young to the right (south-east), and thus the F2 fold is downward facing. The masonry buttress is c. $4 \mathrm{~m}$ high. See Thomas (1988, figure 1.5) for an annotated sketch of this view. (Photo: P.R. Thomas.) 
Figure 34 The exposed hinge of the Bohespic Antiform in the A9 road cut near the Allt Chrom, looking north (locality 4). Car gives scale. See Thomas (1988, figure 1.4) for an annotated sketch of this view. (Photo: P.R. Thomas.)

Figure 35 Downwards- and SE-facing F2 folds on the rock faces of the Clunes Cut on the A9 road, looking north-east (locality 6). Height of section about 8 metres. (Photo: J.E. Treagus.)

Figure 36 Sedimentary dykes of schistose semipelite in schistose psammite (top, centre), cross-lamination and slump folds in the River Garry, Struan (locality 7). Beds young to the right (south-east) on the steep overturned limb of an F2 fold. The compass is $C .5 \mathrm{~cm}$ in diameter. (Photo: P.R. Thomas.)

Figure 37 Map of the Creag nan Caisean-Meall Reamhar GCR site after Thomas (1965). Minor intrusions are not shown.

Figure 38 Exposure near the forestry road on the south flank of Creag nan Caisean at NN 771 601, where a strong penetrative schistosity (S1) cuts steeply dipping, cross-laminated (SS) schistose psammite. The hand lens is c. $3 \mathrm{~cm}$ in diameter. (Photo: P.R. Thomas.)

\section{Figure 39}

(a) Structural map of the Trinafour Monoform and the adjacent area around Meal Dail Chealach and Loch Errochty. AC Allt Culaibh Antiform, AS Allt Sleibh Antiform, CS Croftnagowan Synform, ML Meal na Leitreach Synform, SC Sron Con fold-pair, TM Trinafour Monoform.

(b) Schematic profile view of the map in (a), looking east-southeast. Adapted from Thomas (1980).

Figure 40 Minor $F t$ monoformal fold related to the Trinafour Monoform on the west flank of Sron Chon (NN 680 668), north of Loch Errochty. The fold is plunging at $20^{\circ}$ to $165^{\circ}$ (away from the camera) and is cut by a small thrust plane. The hammer shaft is $30 \mathrm{~cm}$ long. (Photo: P.R. Thomas.)

Figure 41 Geology of the Strath Fionan area based on mapping by J.E. Treagus and P.A.R. Nell. After BGS $1: 10000$ sheet NN75NW (1997) and Treagus (2000, figure 4).

Figure 42 Thinly bedded Beoil Quartzite in Strath Fionan exhibits an F2 fold-pair, verging south in the centre of the picture. To the right of the F2 synform is a tight F1 closure folded by another F2 antiform. View to the east from NN 721576, c. $300 \mathrm{~m}$ north-east of Lochan an Daimh. Hammer head is $15 \mathrm{~cm}$ long. (Photo: J.E. Treagus.)

Figure 43 The lower limestone of the Blair Atholl Dark Limestone and Dark Schist Formation in the hinge-zone of an F2 fold in Strath Fionan. View to the south-east from NN 717570, c. $200 \mathrm{~m}$ southwest of Lochan an Daimh. Outcrop is about $10 \mathrm{~m}$ wide. (Photo: J.E. Treagus.)

Figure 44 Map of the Tempar Burn area based on mapping of P.A.R. Nell (BGS 1:10 000 sheet NN65NE). 
Figure 45 Exposure of a boulder bed close to the Tempar Burn track at NN 696 565, showing elongation of stones parallel to a vertical cleavage; the holes are weathered-out dolomitic clasts, whilst the stones that are proud are of granite, quartzite and biotite-muscovite semipelite (e.g. large clast to the right of the hammer shaft). Hammer shaft is $30 \mathrm{~cm}$ long. (Photo: J.E. Treagus.)

Figure 46 Map of the lower part of the Allt Druidh, after P.A.R. Nell (BGS 1:10 000 sheet NN65NW).

Figure 47 Map of the hinge-zone of the Ruskich Antiform in the Slatich area based on mapping of P.A.R. Nell (BGS 1:10 000 sheet NN64NW). Adapted from Treagus, 2000, figure 7.

Figure 48 Cut surface of finely bedded quartzite and amphibolite of the Farragon Formation, c. $800 \mathrm{~m}$ east-north-east of Slatich, Glen Lyon (NN 6407 4778). Isoclinal Fl folds (arrowed) are refolded by more-open F2 folds. Scale bar in centimeters. (Photo: J.E. Treagus.)

Figure 49 Map and cross-section ( $A-B)$ of the area south-west of the Ben Lawers mountain range, showing localities 1-5, described in the text. Boundaries are based on the original Geological Survey 1:63 360 Sheet 46 (1900), except those of the Farragon Volcanic Formation. The latter boundaries are extrapolated from observations at localities 2 and 4, assuming a constant thickness. Structural data is from Nell (1984) and Treagus (1964b and unpublished). The geometry of folds shown at the key localities on the cross-section are representative of the vergence of the F2 folds.

Figure 50 Cut surface of a typical calcareous schist of the Ben Lawers Schist Formation from the south-east shore of Lochan na Lairige (NN 601 393). The S4 crenulation cleavage is well developed in the lower part of the specimen, while the calcareous quartzite bed near its top exhibits open F4 folding, which at the left-hand edge refolds a tight F2 fold-pair. Scale in centimetres. (Photo: J.E. Treagus.)

Figure 51 Map of Creag an Chanaich and the area of opencast pits. Mapping west of easting 8145 is based on Moles (1985a) and Treagus (2000); to the east it is based on unpublished mapping by J.M. Maclachlan and N.J. Butcher. Compilation and structural observations by J.E Treagus.

Figure 52 Schematic down-plunge profile view of major and minor F2 and F3 folds in the area of the craig an Chanaich mine and opencast pits. A plunge of $25^{\circ}$ to $255^{\circ}$ is assumed; fault movement restored. After Pattrick and Treagus (1996, figure 6).

Figure 53 The opencast workings at Creag an Chanaich, in which Ben Eagach Schist (dark area, centre) is exposed in the core of an F2 synform within the stratiform baryte. Cliff exposure is $10 \mathrm{~m}$ high. (Photo: J.E. Treagus.)

Figure 54 
(a) Map of the Auchtertyre area.

(b) Equal-area stereographic projection of poles to s2 planes and hinges of $F 2$ folds (the range of plunge of folds with strongly curvilinear hinges is shown by the dashed lines). See text for explanation.

Figure 55 Curvilinear F2 fold hinge in the Allt Gleann a' Chlachain, Auchtertyre GCR site. Hammer head is $15 \mathrm{~cm}$ long. (Photo: J.E. Treagus.)

Figure 56 Refolded ?F1 folds in the Allt Gleann a' Chlachain, Auchtertyre GCR site. Pen is $13 \mathrm{~cm}$ long. (Photo: J.E. Treagus.)

Figure 57 Map of the Ben Oss Fault-zone with the Tyndrum Fault immediately to its south-east, occupied by a microdiorite dyke. The outcrop of the Ben Lawers Schist (ornamented) is shown between the two faults and its margin with the Ben Lui Schist is shown to the north-west of the Ben Oss Fault. The inset shows, (a) the left-lateral movement on the Tyndrum Fault and (b) the subsequent locking by the dyke and right-lateral movement transferred to the Ben Oss Fault.

Figure 58 Vertical aerial photograph of the northern flank of Ben Oss, showing the Ben Oss Fault (stream gully in centre with large arrows at each end) and fractures orientated at $20^{\circ}$ anticlockwise to the fault on its north-west side (indicated by small arrows). See text for explanation. (Aerial Photograph () Getmapping. )

Table 1 Summary of the Dalradian sequence in the Schiehallion district (adapted from Treagus, 2000).

* the Atholl and Strathtummel subgroups of Treagus (2000) are no longer recognized; the strata are now regarded as part of the Glen Spean Subgroup. 


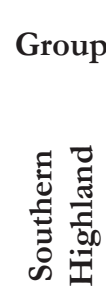

Subgroup

Formation

Pitlochry Schist Fm with Green Beds

Loch Tay Limestone Fm

Ben Lui Schist Fm

Farragon Volcanic Fm

Ben Lawers Schist Fm

Ben Eagach Schist Fm

Carn Mairg Quartzite Fm

Killiecrankie Schist Fm

Schiehallion Quartzite Fm

Tempar Dolomitic Member

害 Schiehallion Boulder Bed

클

Drumchastle Pale Limestone Fm

Cnoc an Fhithich Banded Semipelite Fm

Blair Atholl Dark Limestone \& Schist Fm

Tullochroisk Semipelite Fm

Strath Fionan Pale Limestone Fm

:

Strath Fionan Banded Semipelite Fm

Meall Dubh Quartzite Fm

Meall Dubh Graphitic Schist Fm

Meall Dubh Limestone Fm

Meall Dubh Striped Pelite Fm

Beoil Schist Fm

Beoil Quartzite Fm

Dunalastair Semipelite Fm

Dunalastair Quartzite Fm

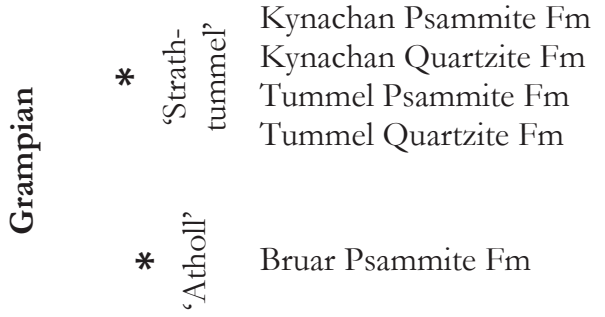

Metasedimentary rocks

Gritty semipelite/psammite gritty hornblende schist

limestone and calc-schist

garnet semipelite/psammite

amphibolite and semipelite

calc-semipelite/amphibolite graphitic pelite/semipelite,

$\mathrm{Ba}-\mathrm{Zn}$ deposit near top

pebbly quartzite

semipelite/psammite

fine-grained quartzite

calc-pelite/semipelite and

dolomitic limestone

diamictite with stones of

granite, quartzite and

limestone in calc-semipelite

matrix

tremolitic/dolomitic limestone semipelite/psammite

limestone/graphitic pelite

banded semipelite/psammite tremolitic/dolomitic limestone pelite/semipelite/psammite pebbly feldspathic quartzite graphitic pelite

tremolite schist/dol. limestone calc-schist and semipelite

muscovite-garnet pelite

thin quartzite

ribbed semipelite/psammite

quartzite/quartz psammite

thick-bedded psammite

feldspathic quartzite

thick-bedded psammite

quartzite/schistose psammite

flaggy psammite/semipelite
Basic volcanism sills + volcaniclastic rocks

Basic volcanism sills + volcaniclastic rocks

volcaniclastic rocks 
Figure 3.1

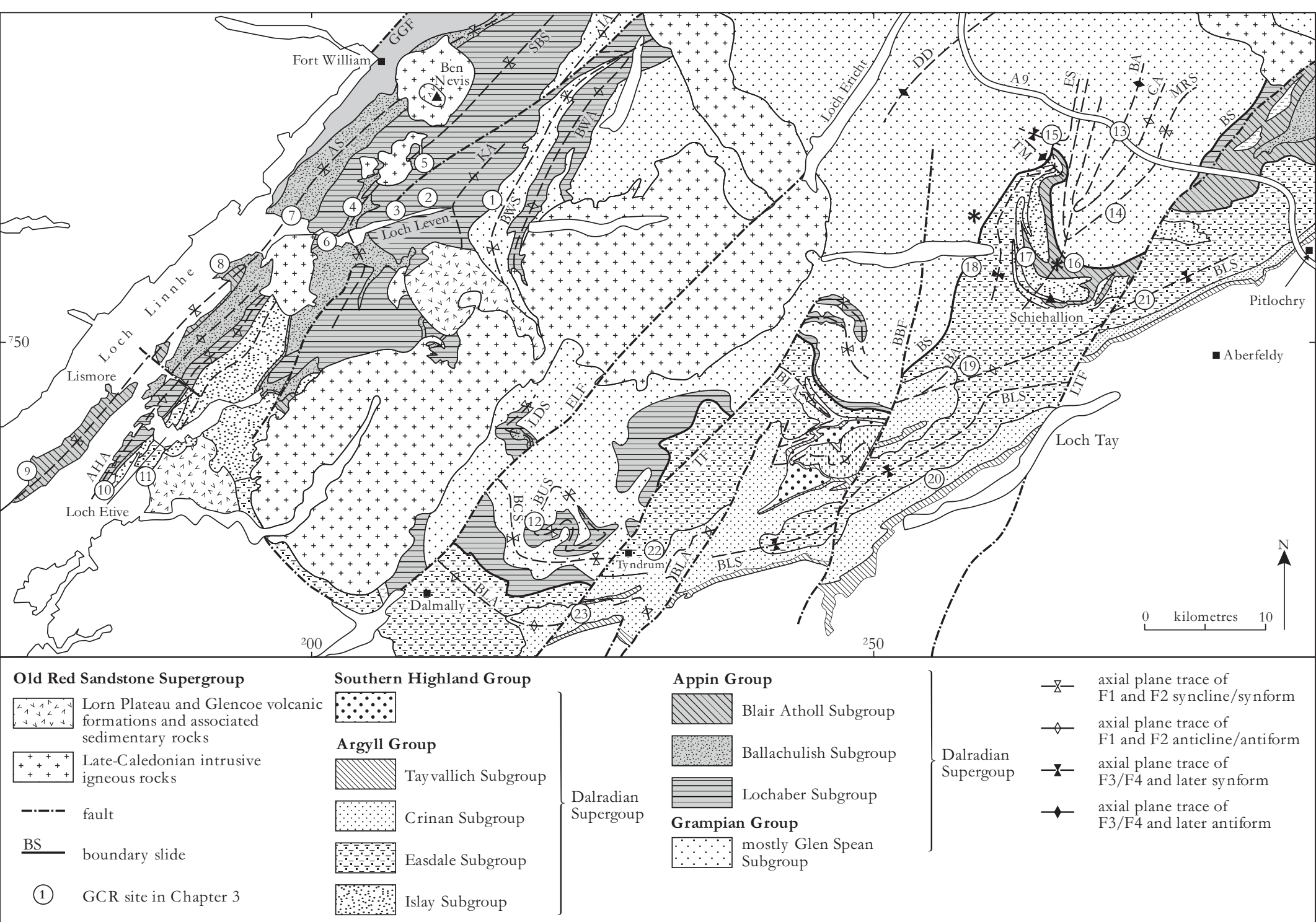


Figure $3.3 a$

\begin{tabular}{|c|c|}
\hline 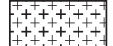 & granite \\
\hline \begin{tabular}{|cccc|c|}
$v$ & $v$ & $v$ & $v$ \\
$v$ & $v$ & $v$ & $v$
\end{tabular} & $\begin{array}{l}\text { Glencoe Caldera- } \\
\text { volcano Complex }\end{array}$ \\
\hline & slide \\
\hline -.-- & fault \\
\hline$-\theta-$ & $\begin{array}{l}\text { axial plane trace of } \\
\text { F1 anticline }\end{array}$ \\
\hline$-\frac{Z}{\Delta}$ & $\begin{array}{l}\text { axial plane trace of } \\
\text { F1 sy ncline }\end{array}$ \\
\hline$-\rightarrow-$ & $\begin{array}{l}\text { axial plane trace of } \\
\text { F2 antiform }\end{array}$ \\
\hline$-\mathbf{z}-$ & $\begin{array}{l}\text { axial plane trace of } \\
\text { F2 sy nform }\end{array}$ \\
\hline
\end{tabular}

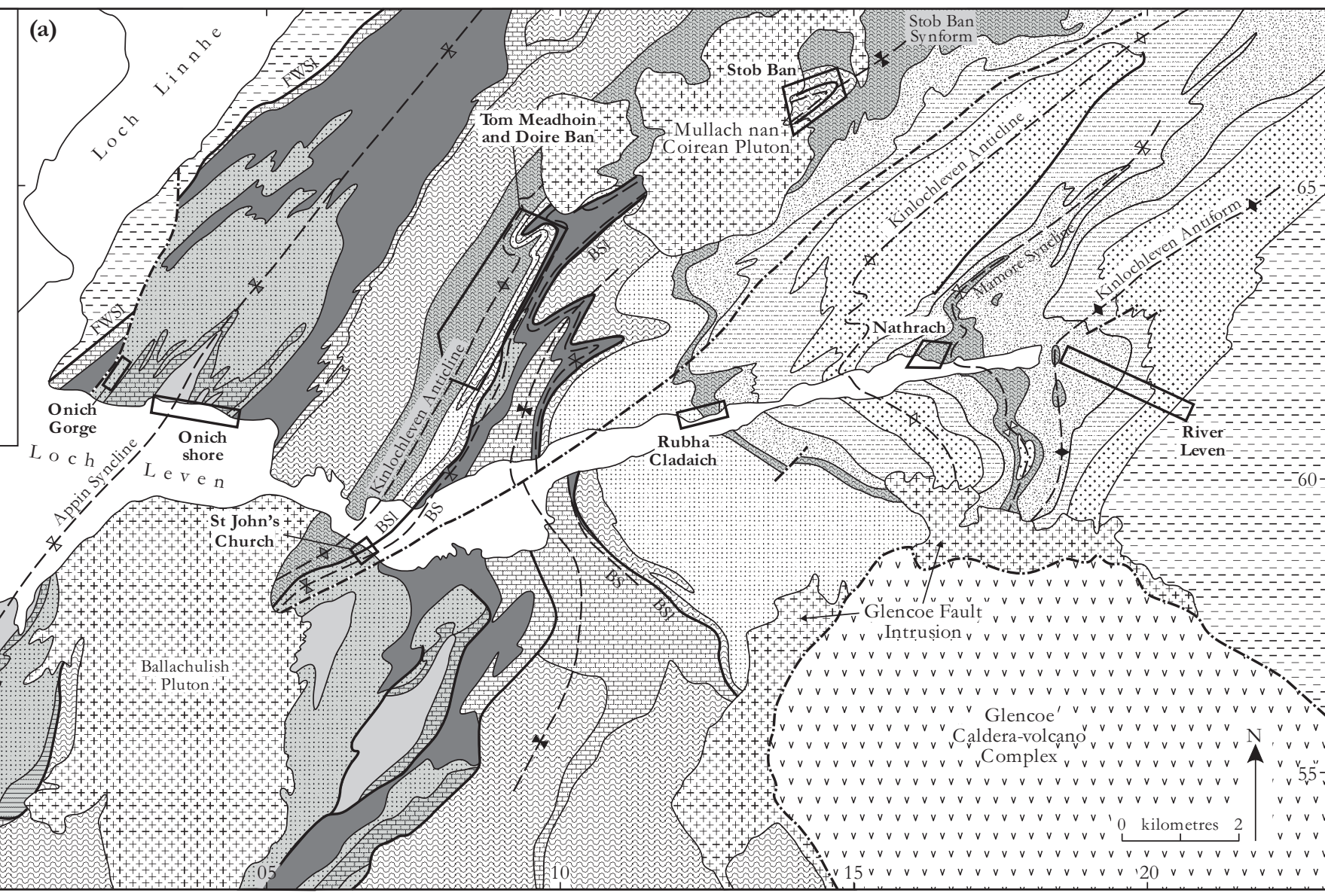

\section{Appin Group}

Ballachulish Subgroup

\begin{tabular}{|c|c|c|c|}
\hline & Cuil Bay Slates & & Appin Quartzite \\
\hline & Appin Phyllites & & Ballachulish Slates \\
\hline & Appin Limestone & & $\begin{array}{l}\text { Ballachulish } \\
\text { Limestone }\end{array}$ \\
\hline
\end{tabular}

Lochaber Subgroup

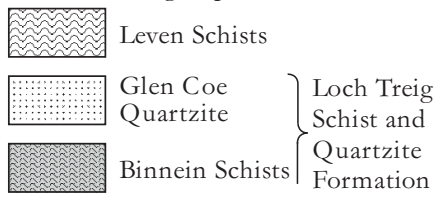

Grampian Group

E-:-二- Eilde Flags

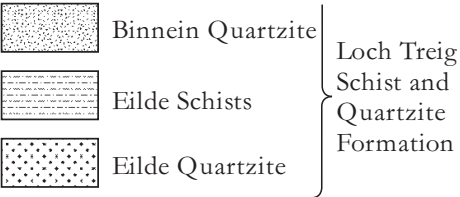




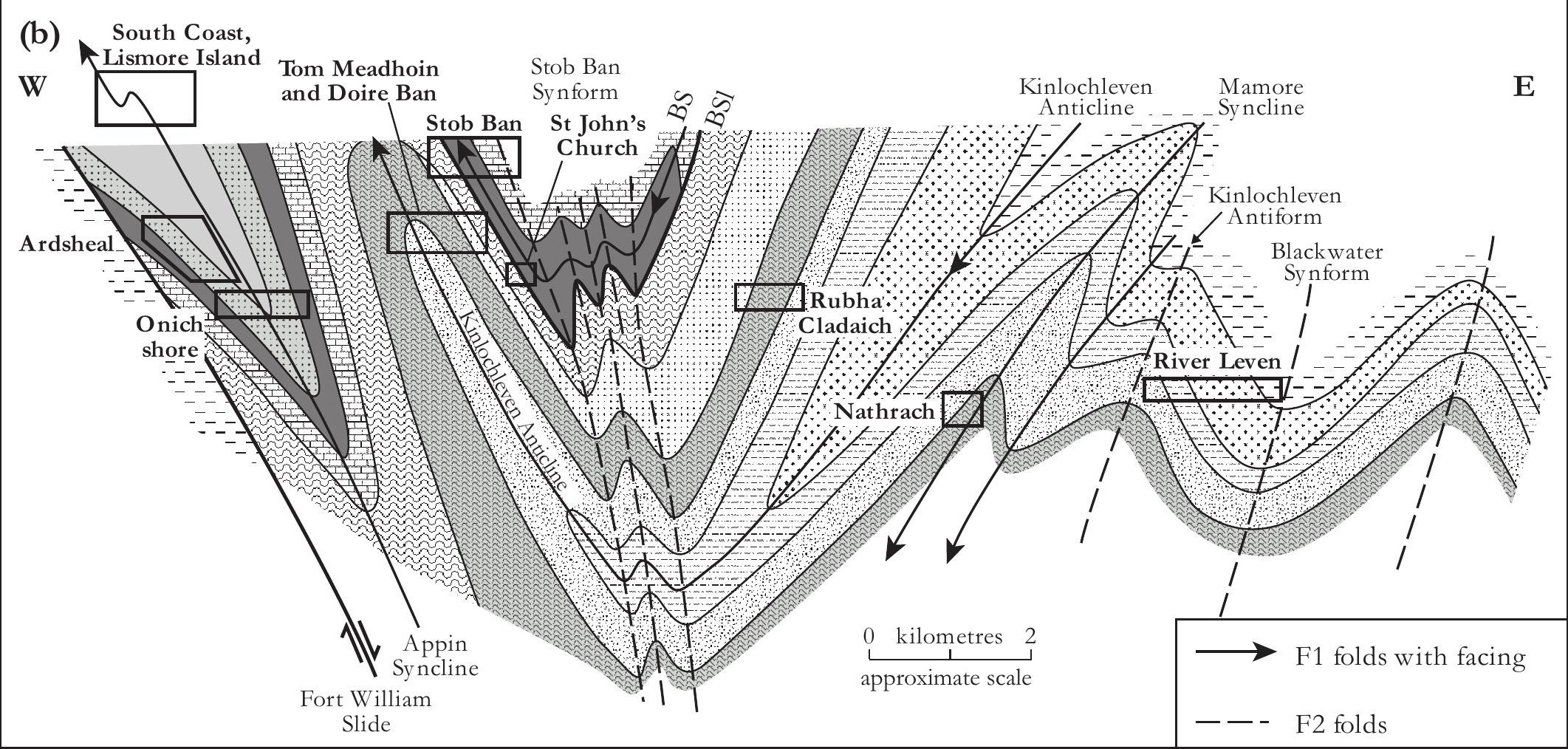




\section{Figure $3.4 a$}

$2 \sqrt{2}$ Pitlochry Schist

Loch Tay Limestone

Ben Lui Schist

23 Ben Lawers Schist

Ben Eagach Schist and
Carn Mairg Quartzite

బava Killiecrankie Schist

Schiehallion Quartzite

Blair Atholl Subgroup

Lochaber and

Ballachulish subgroups

-_-_-_- Struan Flags

(a)

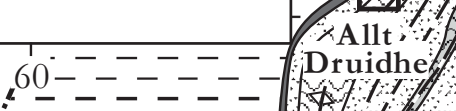

Druidhe
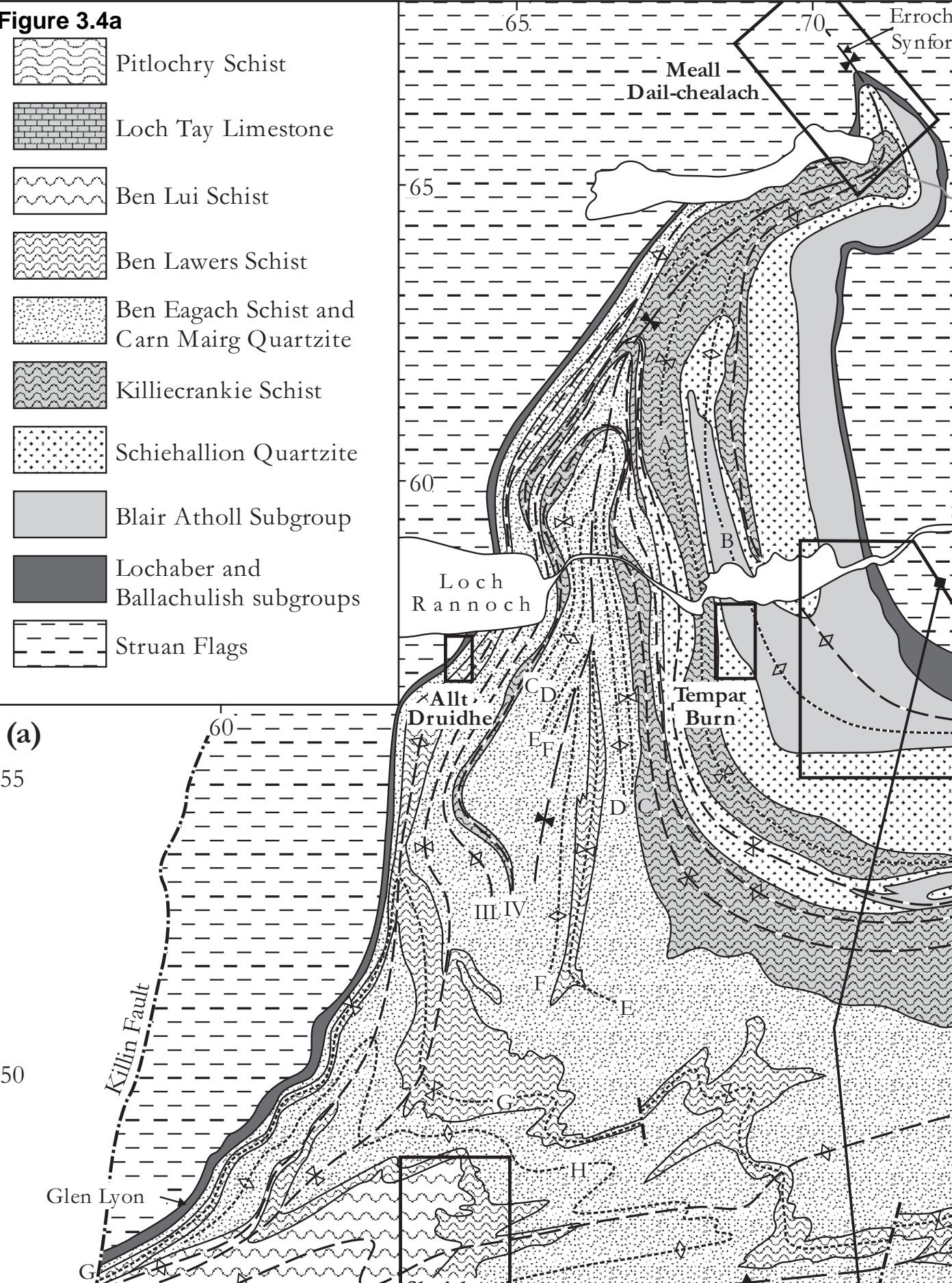

Glen Lyon -
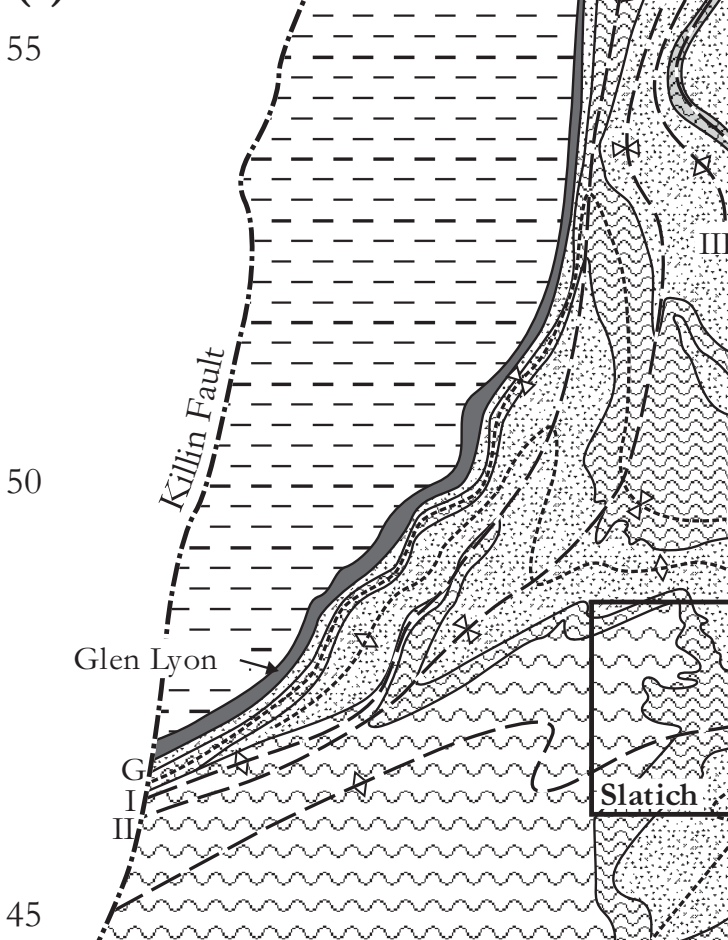

$-45$
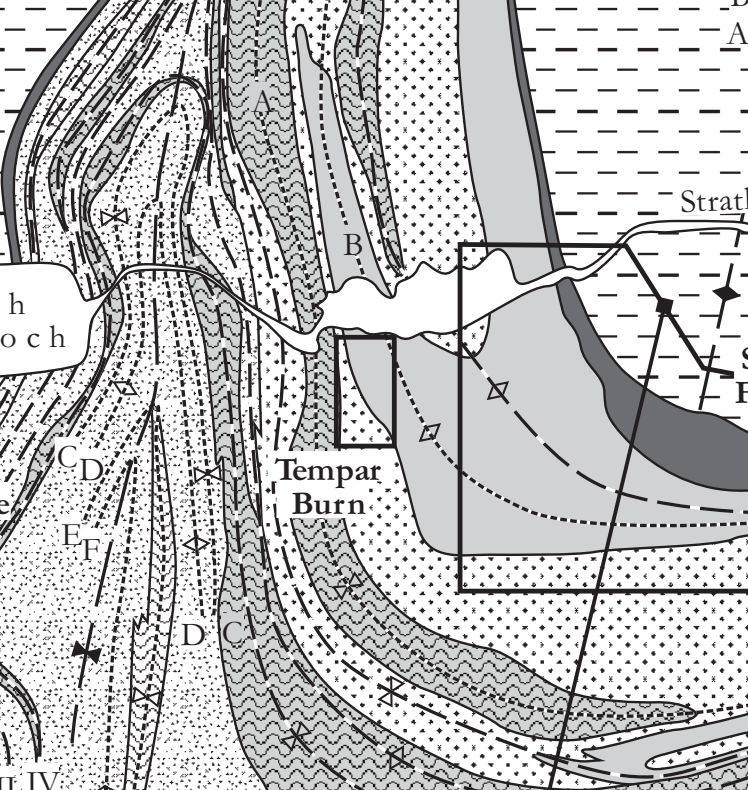

mmel
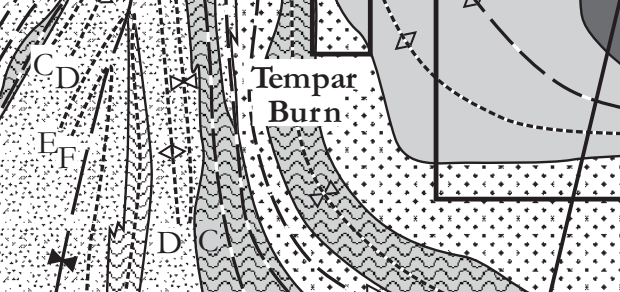

-
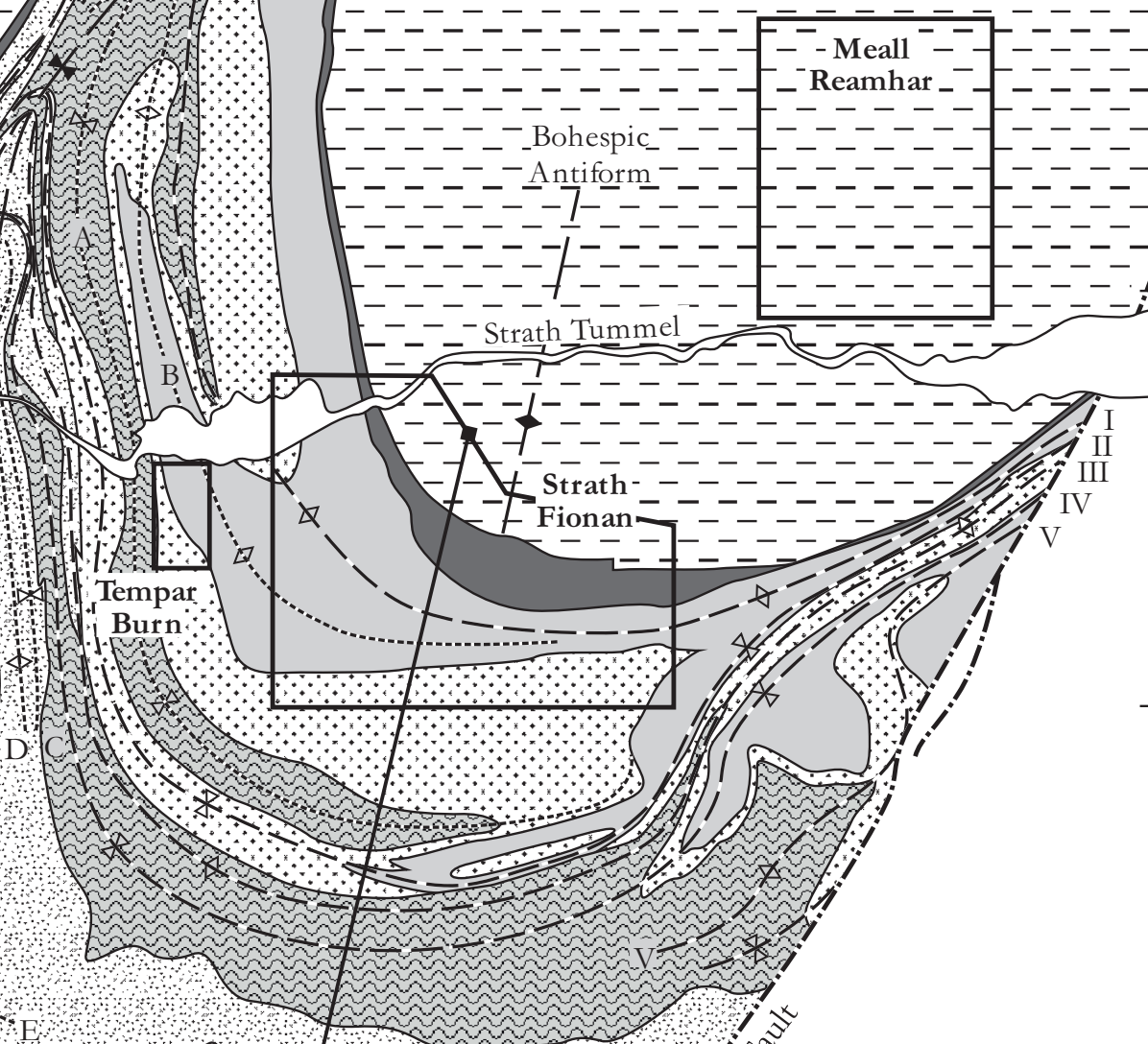<smiles>C1C2C3CC2C13</smiles>
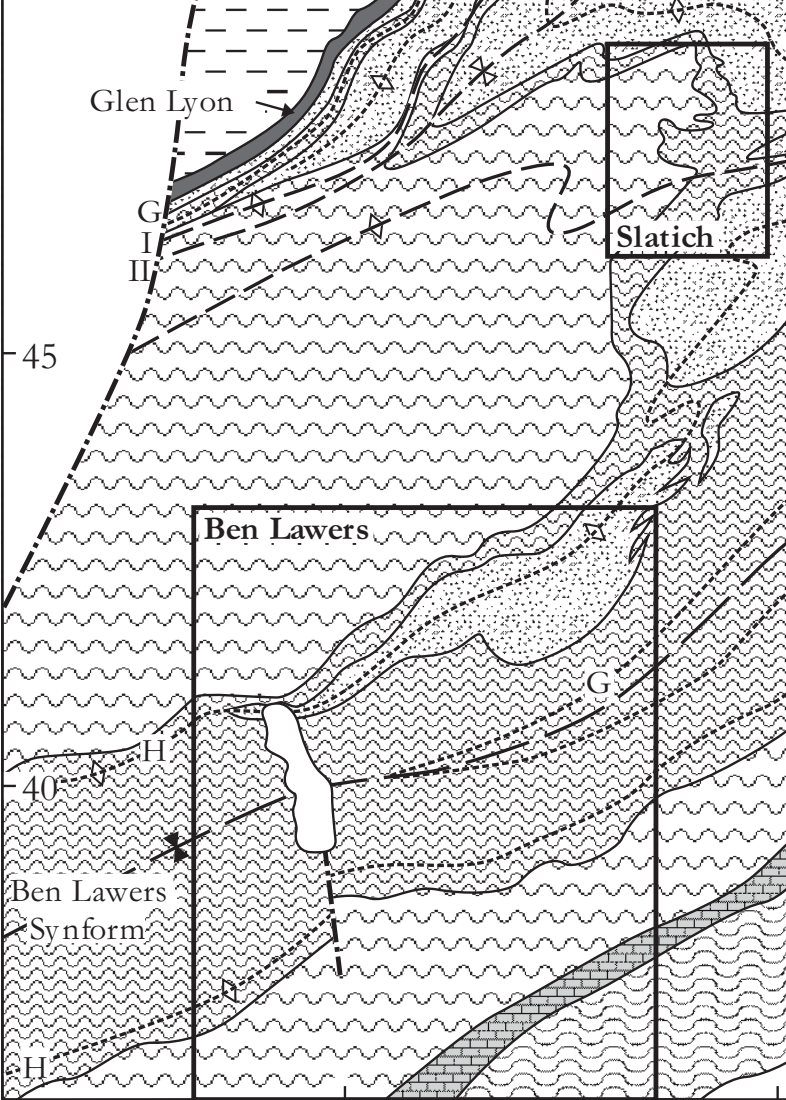

(1)
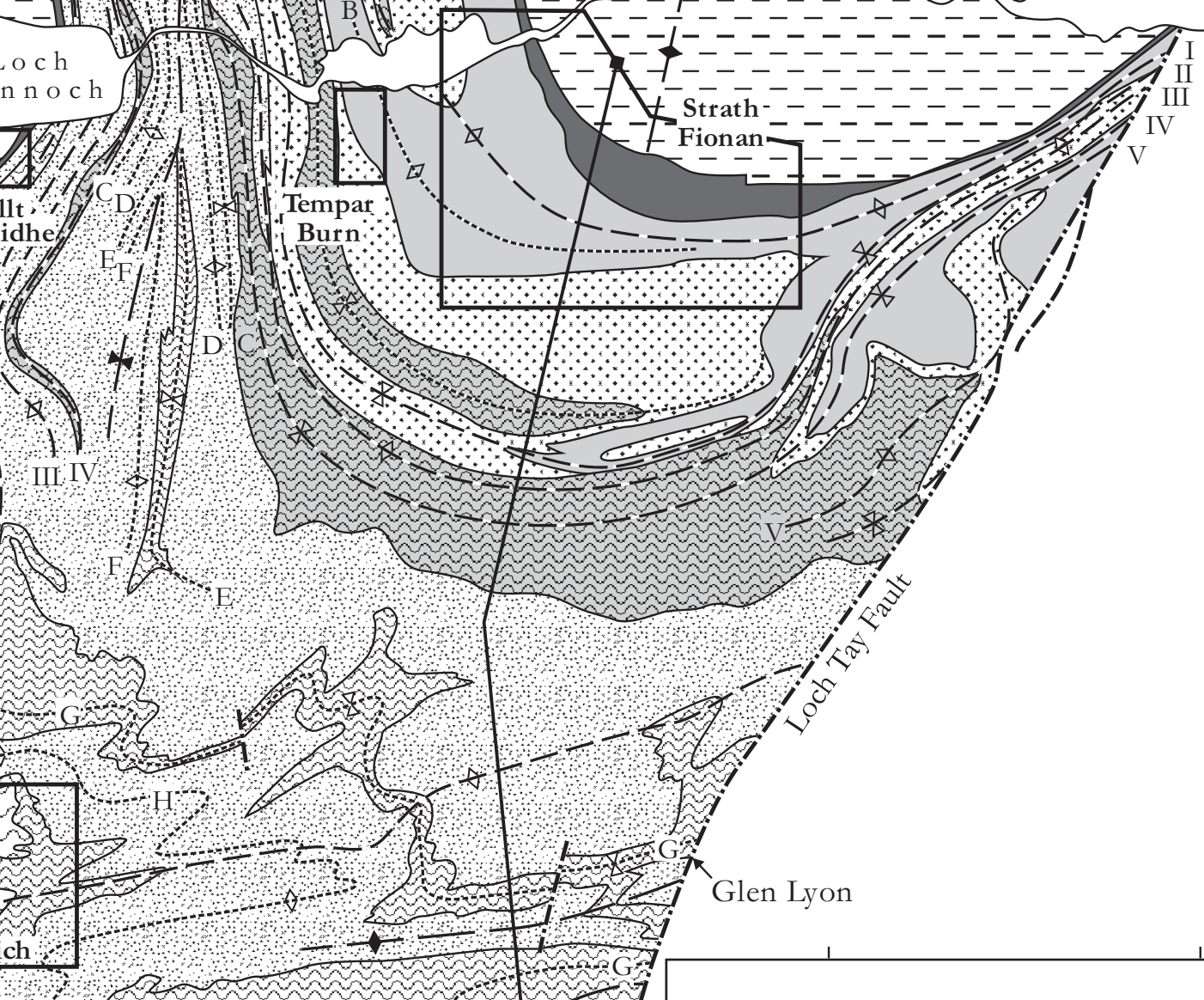

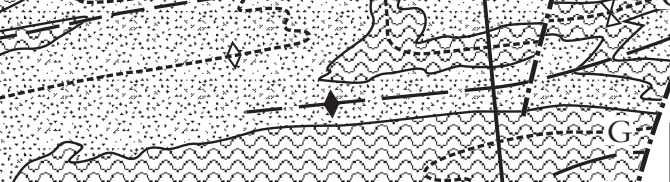

Glen Lyon
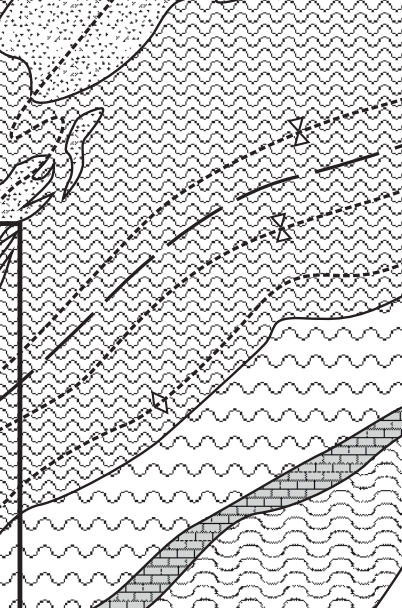
Figure $3.4 b$

(b)

$\mathbf{N}$

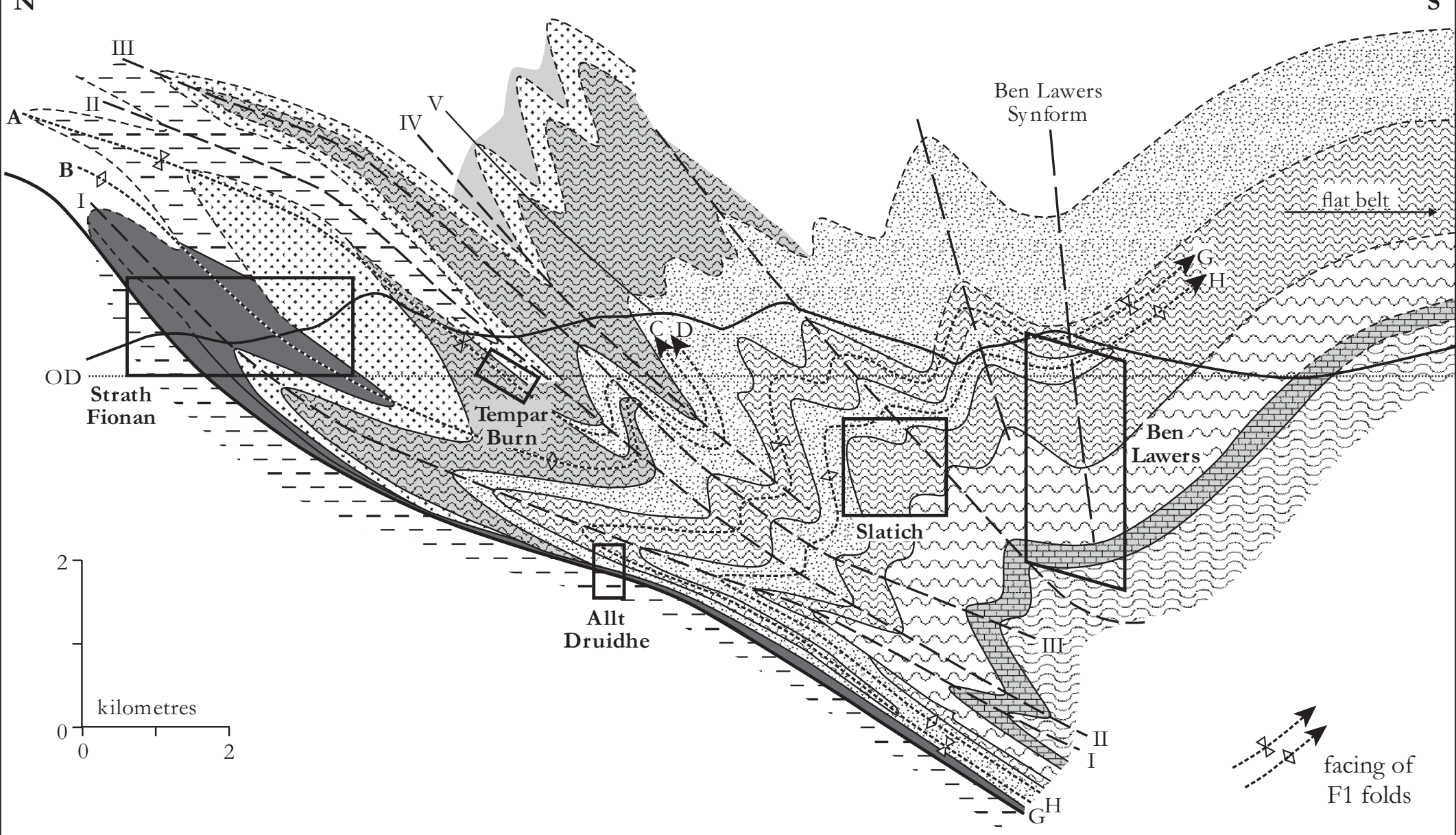


Figure 3.5

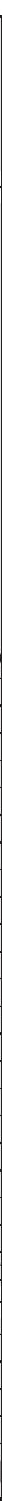




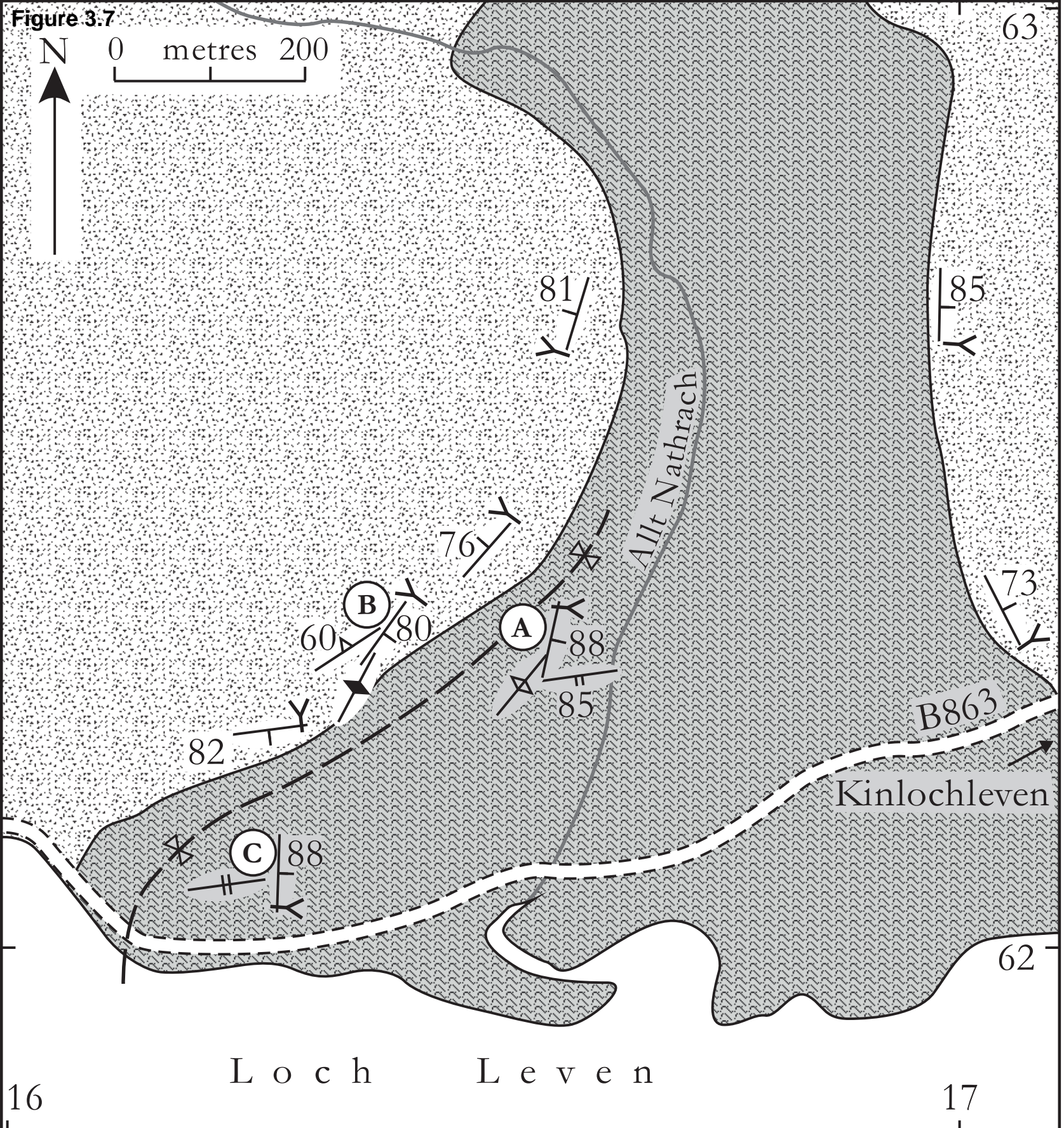

Binnein Schists

Binnein Quartzite

inclined bedding, dip in degrees

$\multimap$ vertical S1 cleavage

inclined S2 cleavage, dip in degrees

- vertical S2 cleavage inclined S3 cleavage, dip in degrees

— vertical S3 cleavage axial plane trace of - Z- F1 Mamore Sy ncline (dow nward facing)

$>\quad \begin{aligned} & \text { direction of } \\ & \text { younging }\end{aligned}$ 


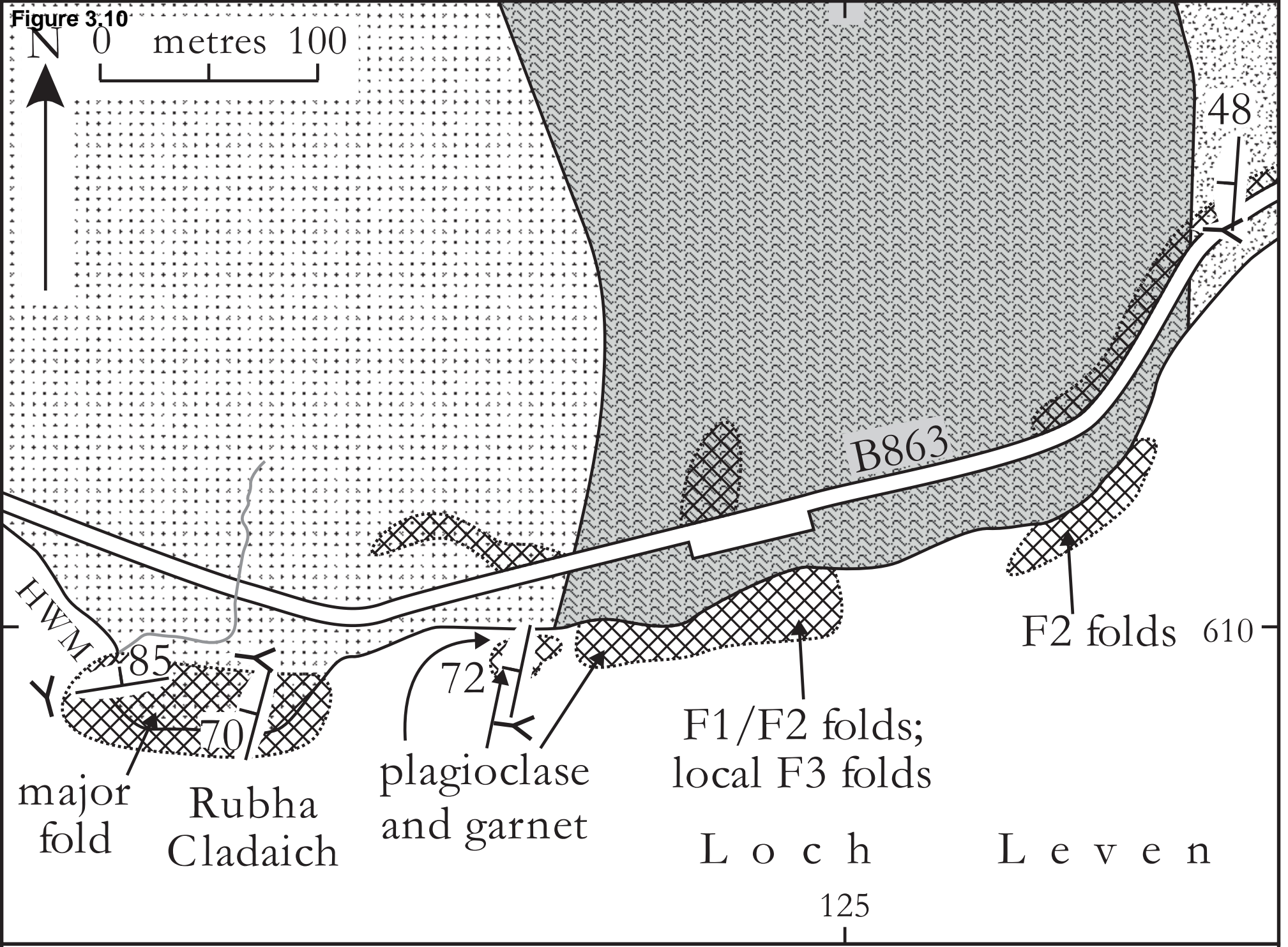

\section{Loch Treig Schist and Quartzite Formation}

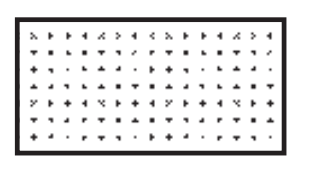

Glen Coe Quartzite Member

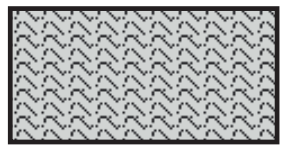

Binnein Schist Member

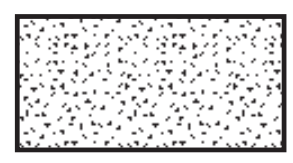

Binnein Quartzite Member

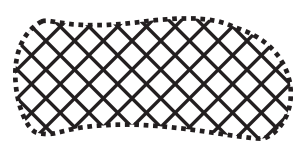

principal exposures

1 inclined bedding, dip in degrees

$>\quad$ direction of younging 


\section{Appin Group}

Ballachulish Subgroup

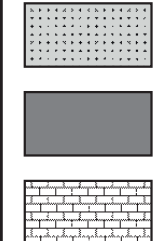
Appin Quartzite

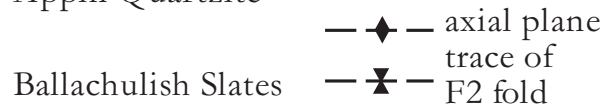

Lochaber Subgroup

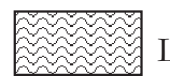

Ballachulish

Limestone

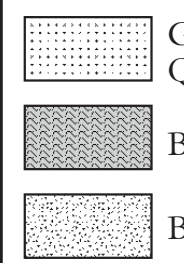

Leven Schists

Glen Coe

Quartzite

Binnein Schists

Binnein Quartzite

..--.--..- axial plane -.-.-...- trace of

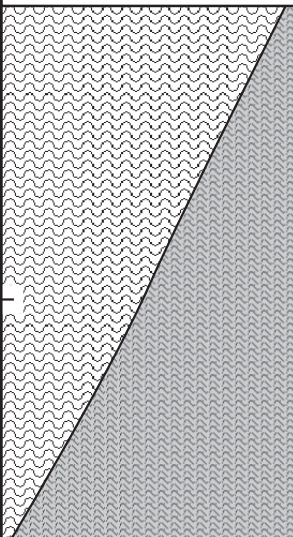

$\stackrel{0}{0}$ metres 500

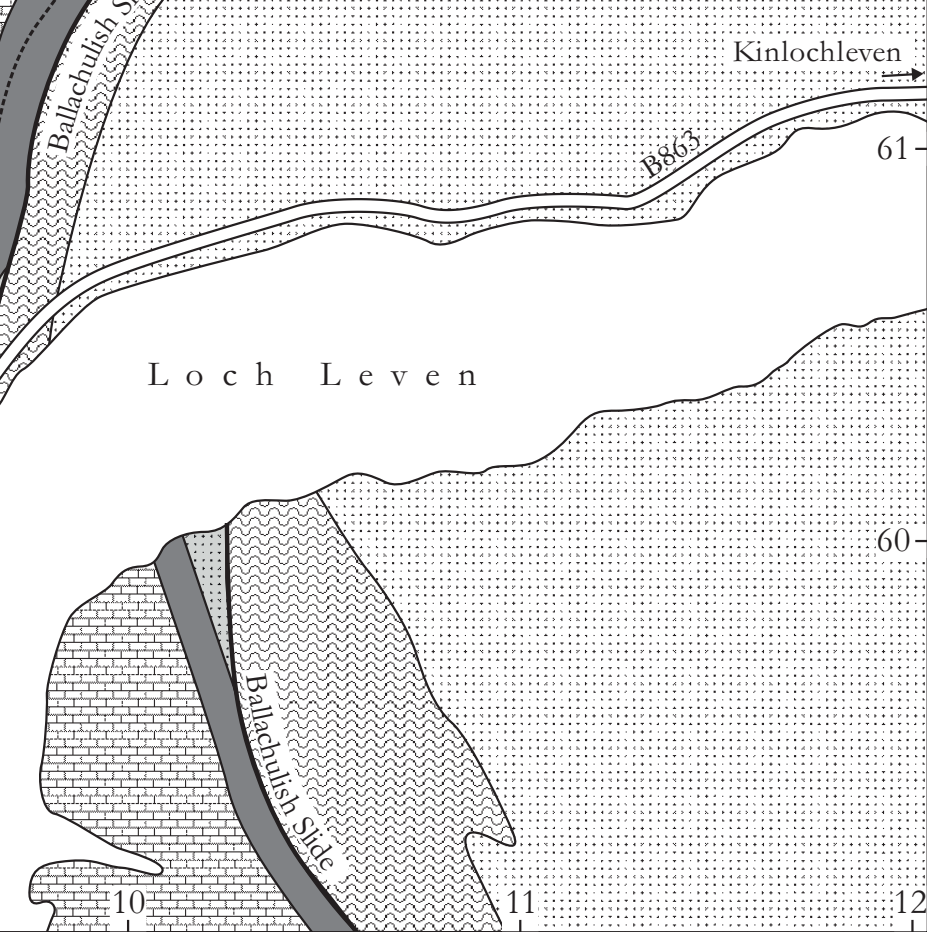


Figure 3.13

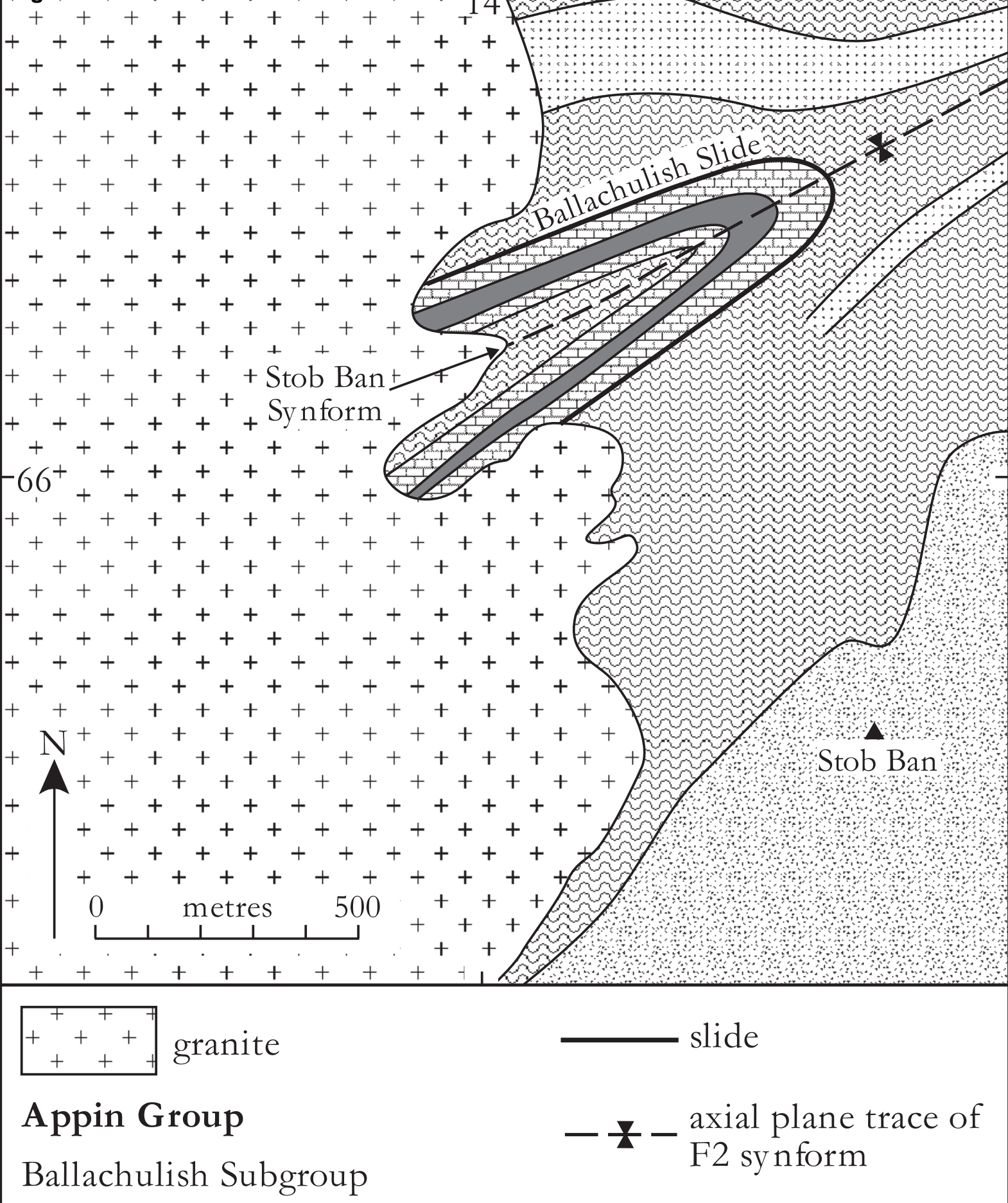

Ballachulish Slates

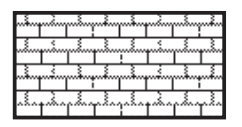

Ballachulish

Limestone

Lochaber Subgroup

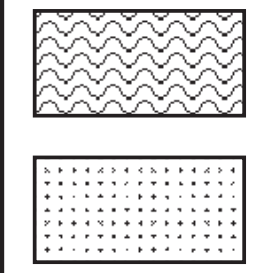

Leven Schists

Glen Coe

Quartzite

Binnein Quartzite 
Figure 3.15

065

0 metres 100

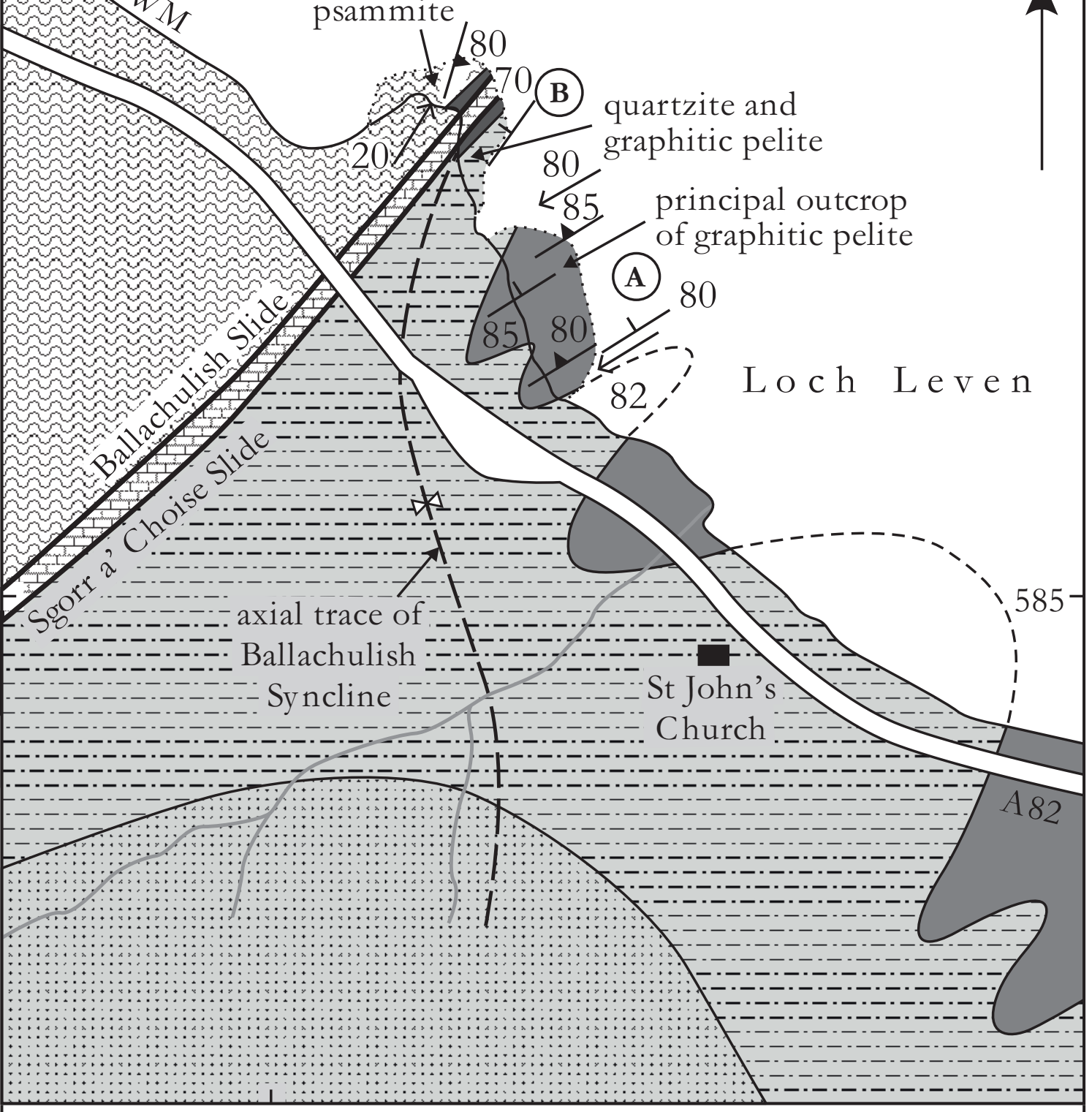

\section{Appin Group}

Ballachulish Subgroup

Appin Quartzite

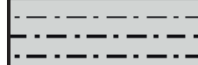

-

Appin Transition Formation

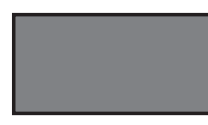

Ballachulish Slates

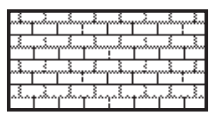

Ballachulish

Limestone

Lochaber Subgroup

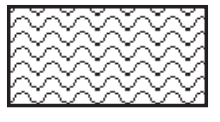

Leven Schists

(lower part)

dykes

$\longrightarrow$ slide

inclined bedding, dip in degrees

__ inclined S1 cleavage, dip in degrees

$\longrightarrow$ axis of F1 fold, plunge in degrees

A localities mentioned
in the text 


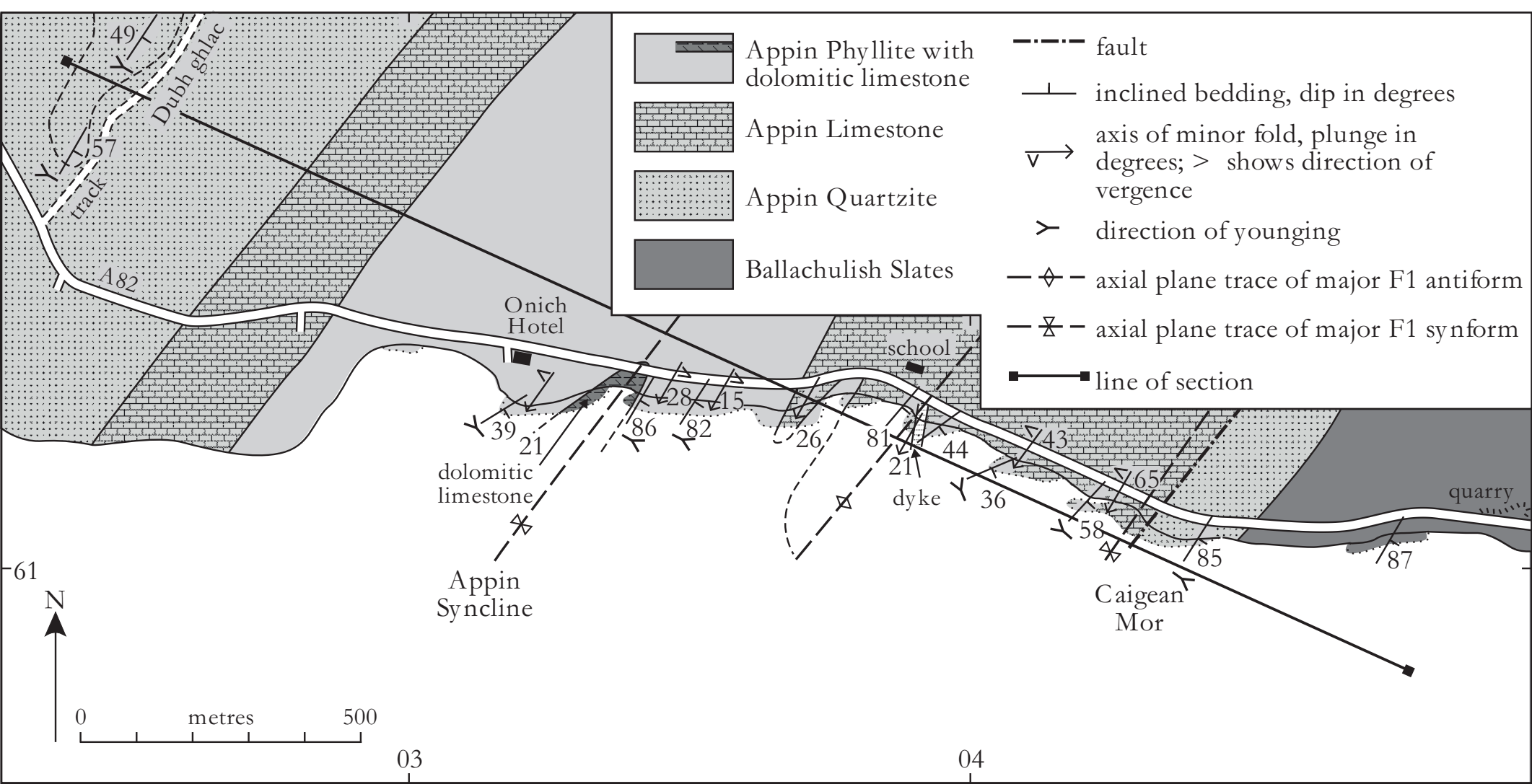




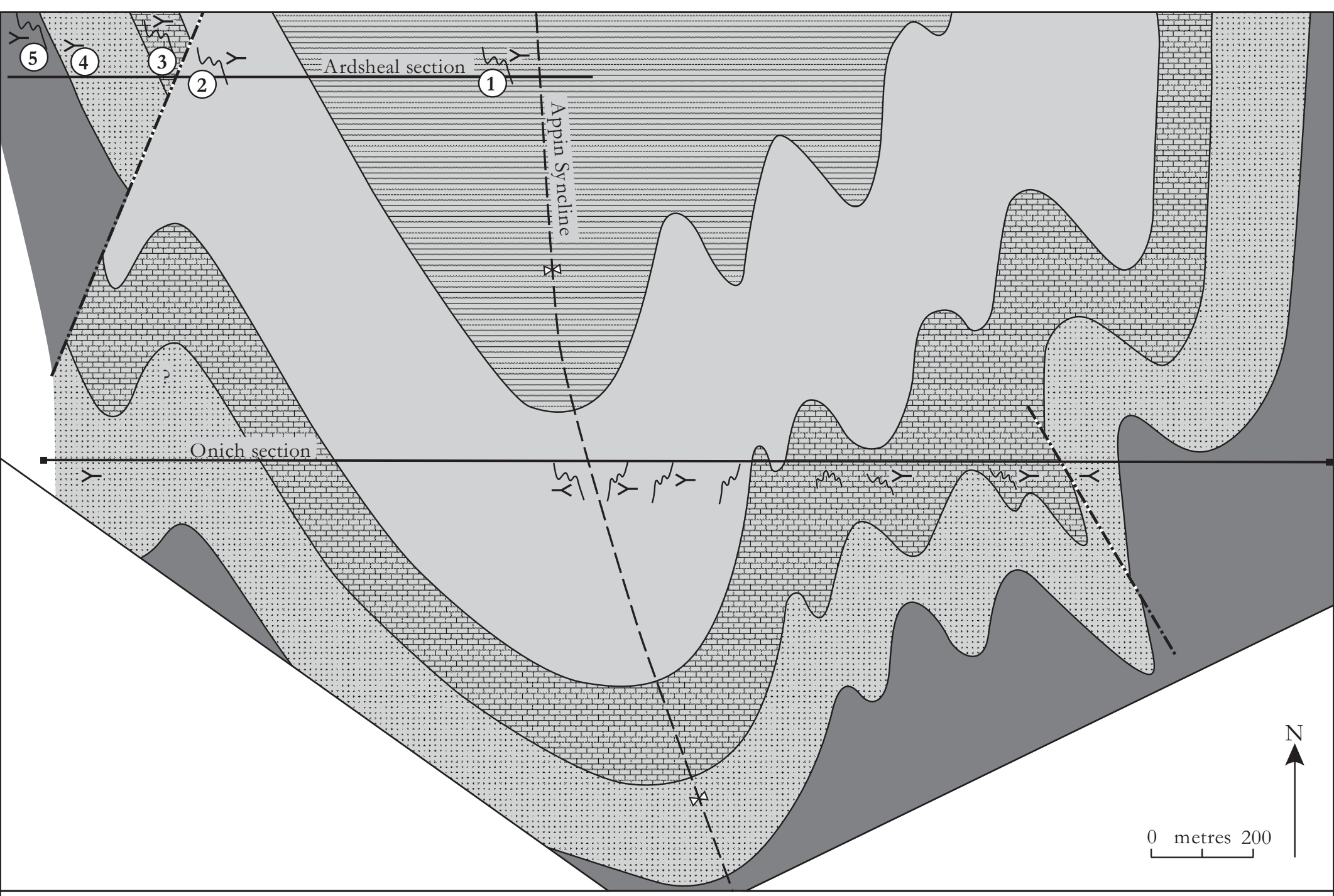

\section{Appin Group}

Ballachulish Subgroup Cuil Bay Slate Appin Phyllite Appin Limestone
Appin Quartzite

Ballachulish Slate and

Appin Transition formations

\section{-.-.- fault}

$\checkmark \quad$ cleavage/bedding and minor fold convergence

$>\quad$ direction of younging

(1)-(5) Ardsheal localities 


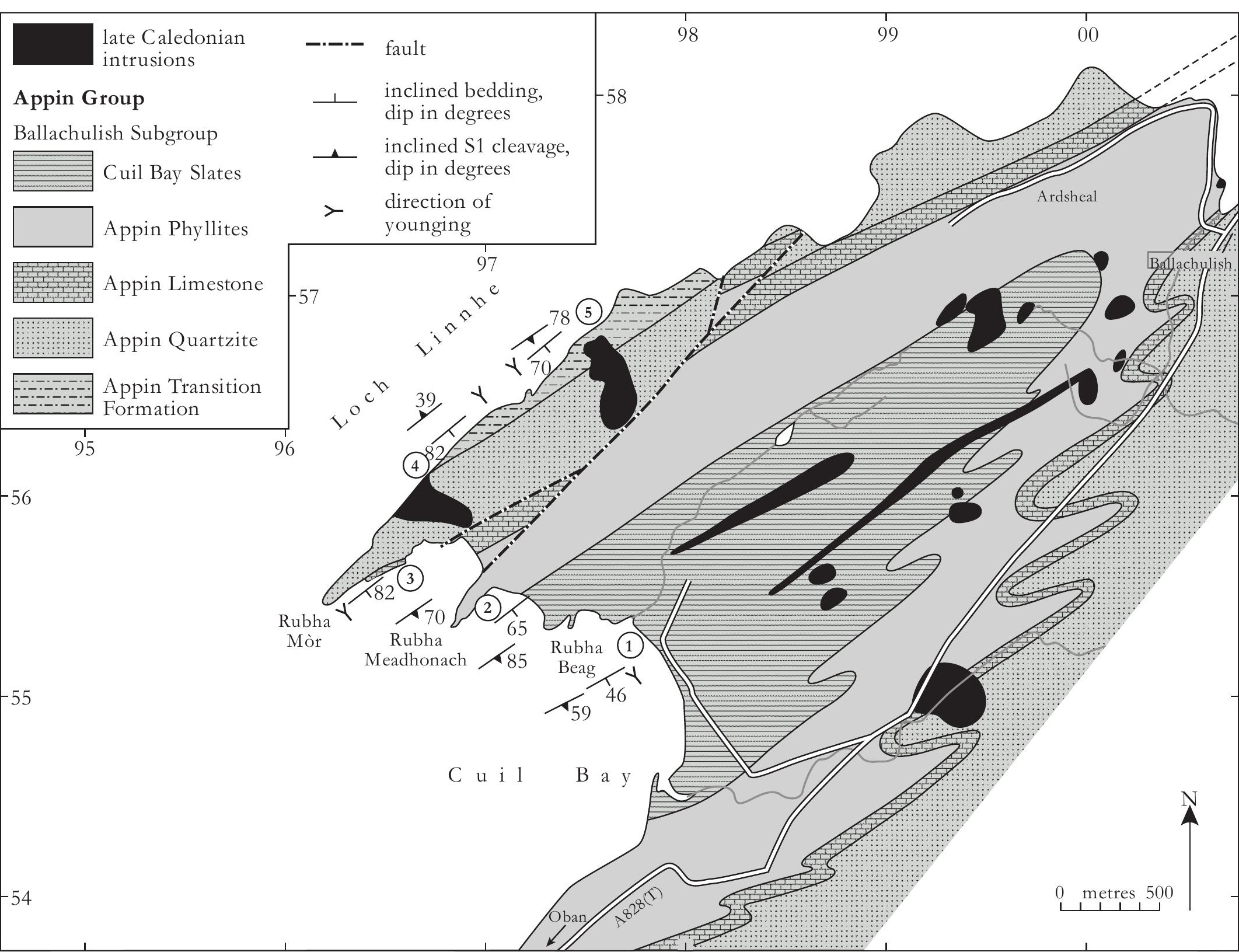




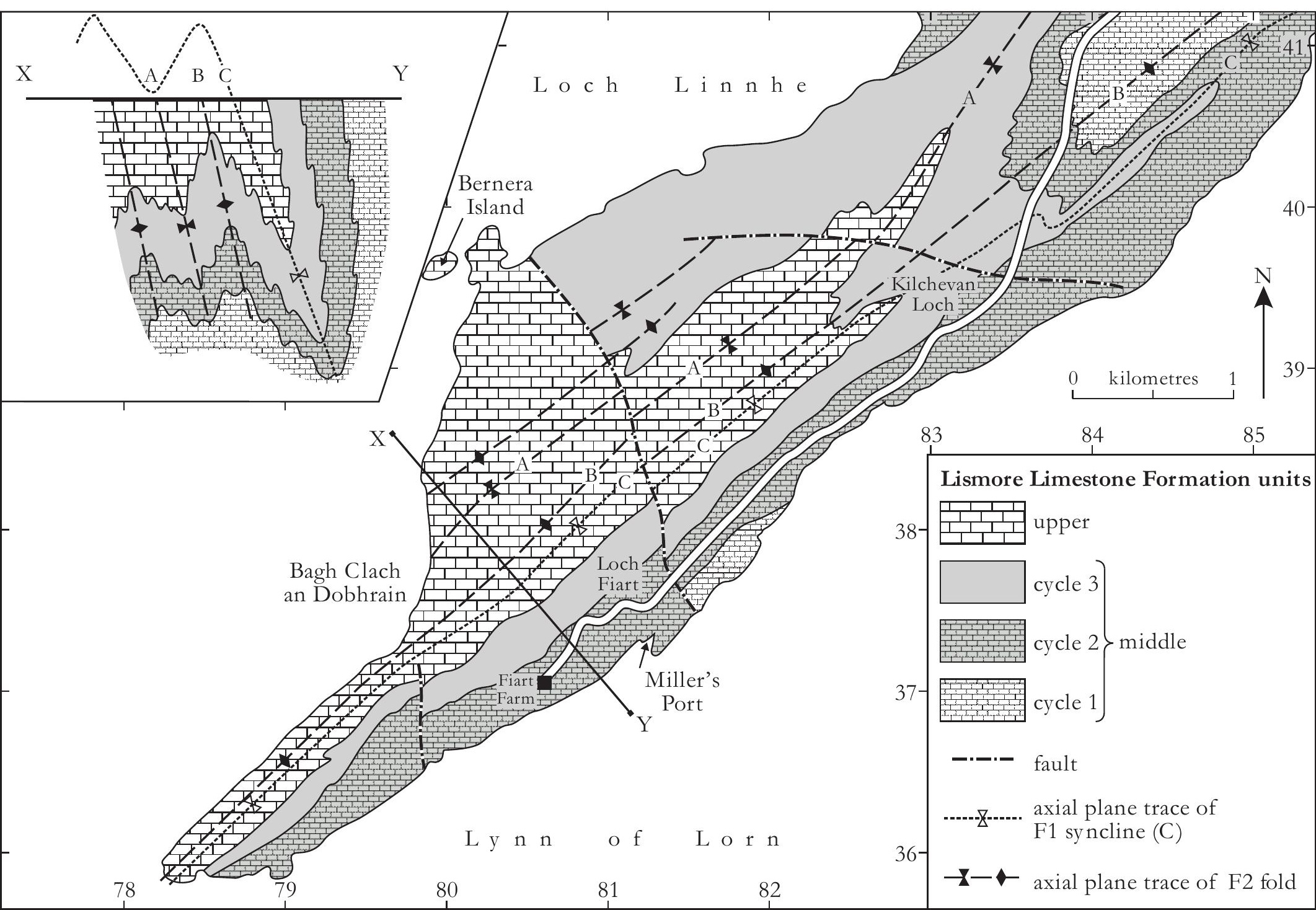


Figure 3.24

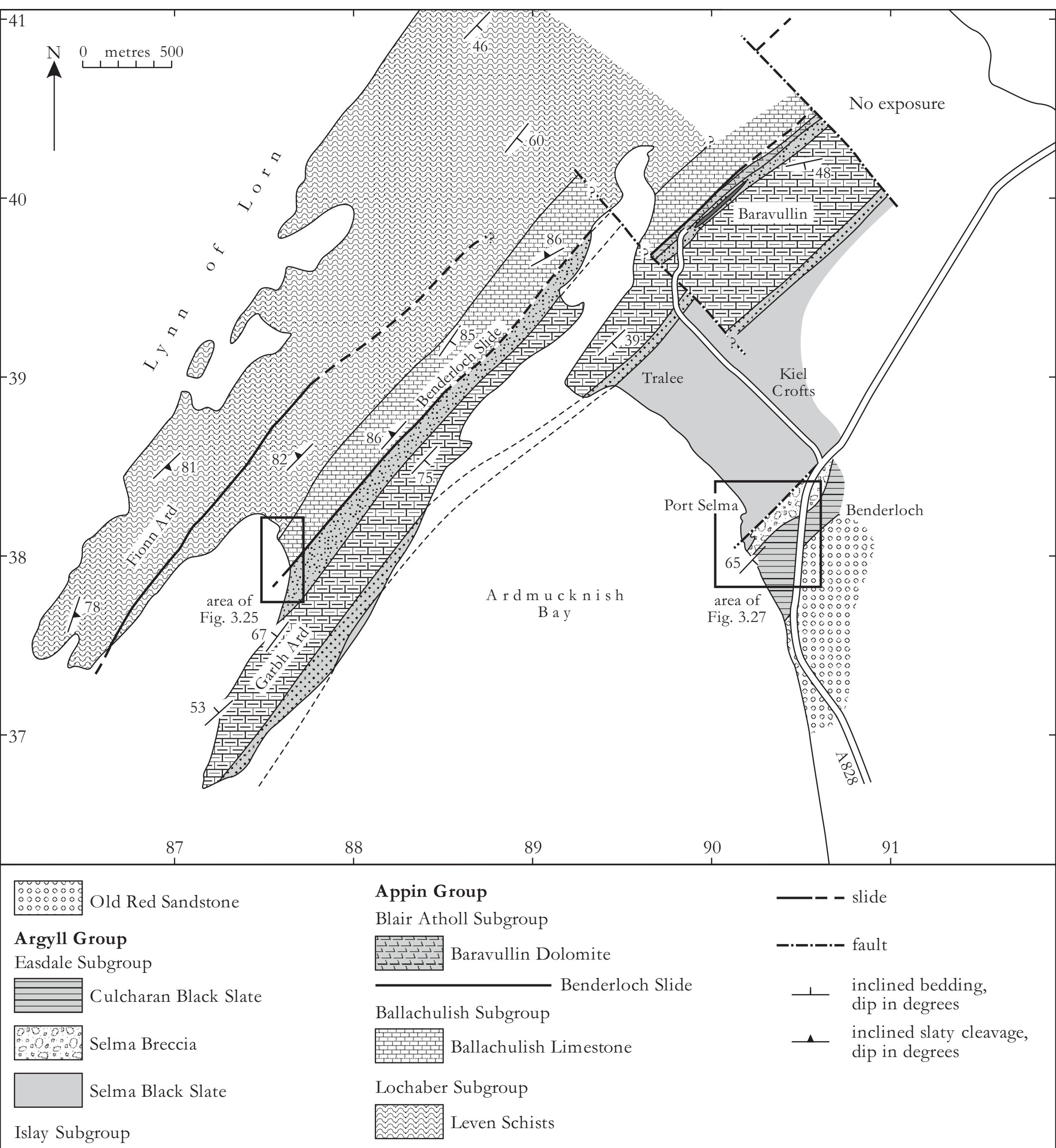

Islay Subgroup

Tralee Bay Quartzite

Castle Dolomitic Flags

Baravullin Quartzite

Baravullin Boulder Bed 


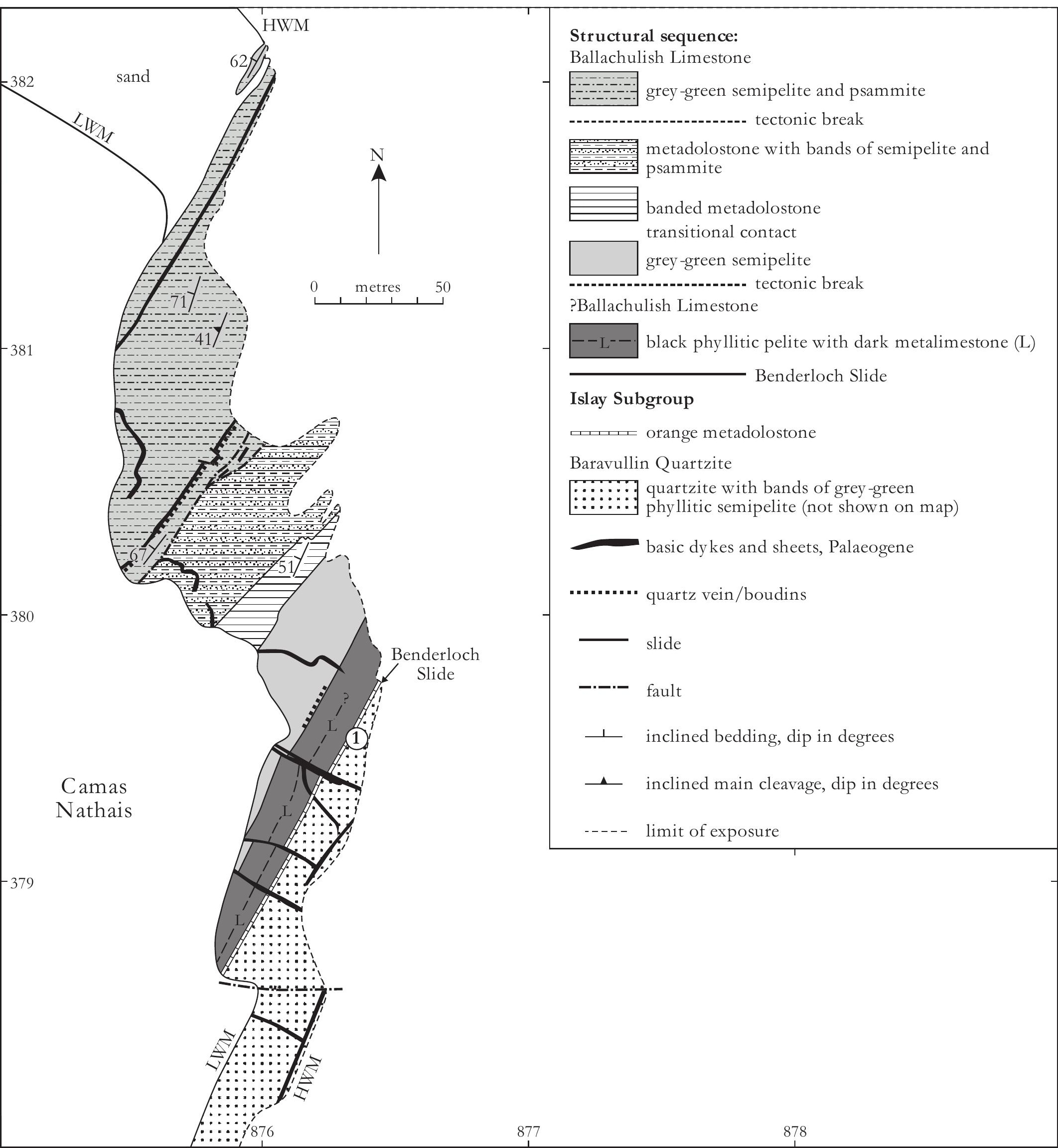


Figgyre 3.27

$-38$

Easdale Subgroup

Selma Breccia

\section{[}

breccia unit 5

IB4 interbreccia unit 4

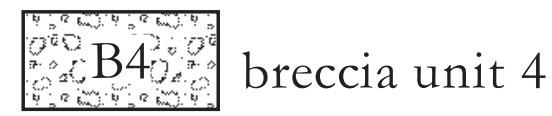

IB3 interbreccia unit 3

-.-- fault

I inclined bedding,

dip in degrees

inclined slaty cleavage, dip in degrees

\section{$>\quad$ direction of younging}

$\forall-$ axial plane trace
of anticline

breccia units $1-3$,

----- limit of exposure

${ }_{1} \mathrm{~B} 1-3$. units 1 and 2

Selma Black Slates

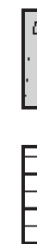
pebbly mudstone black slaty mudstone 


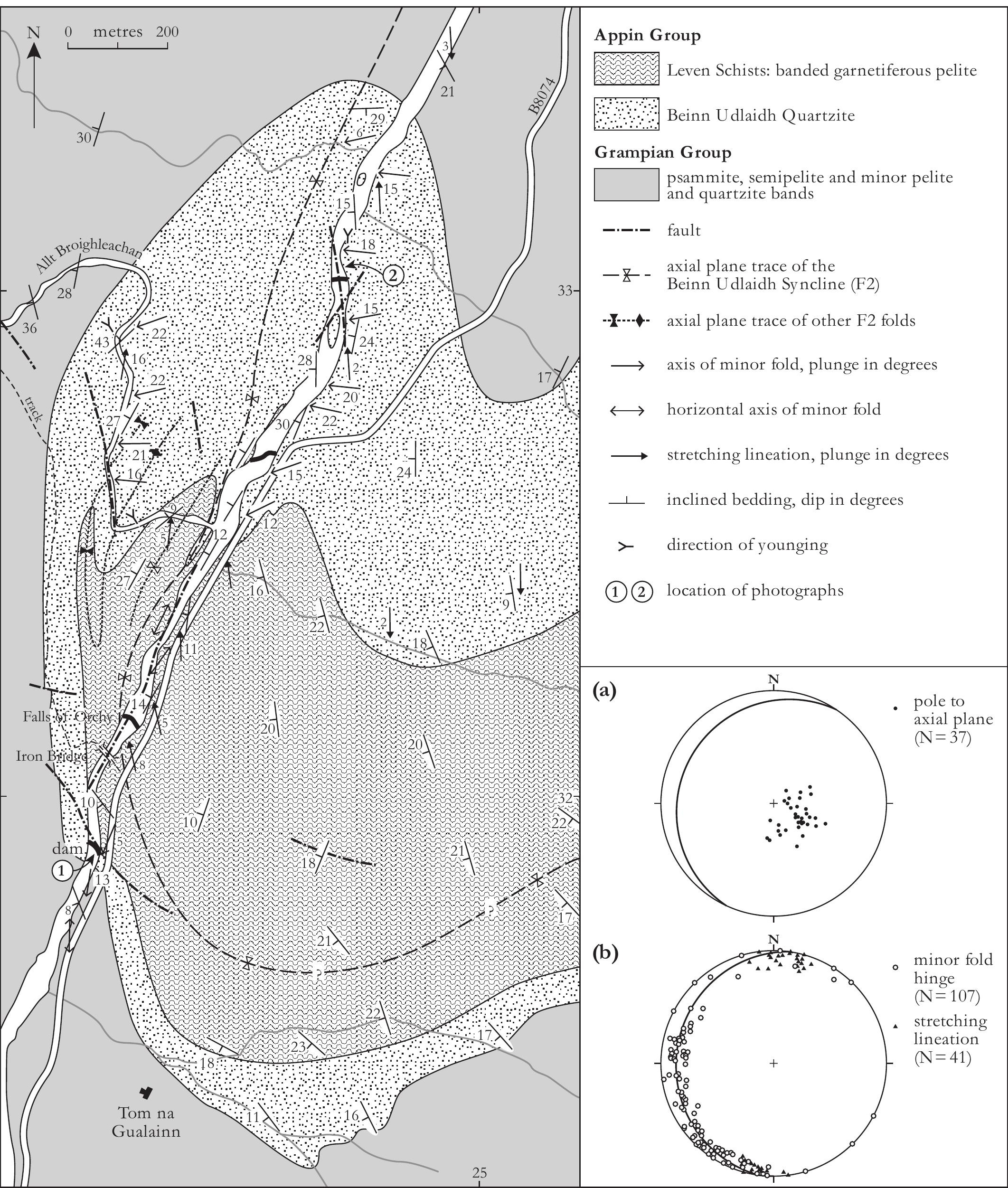




\section{Fgure 3}

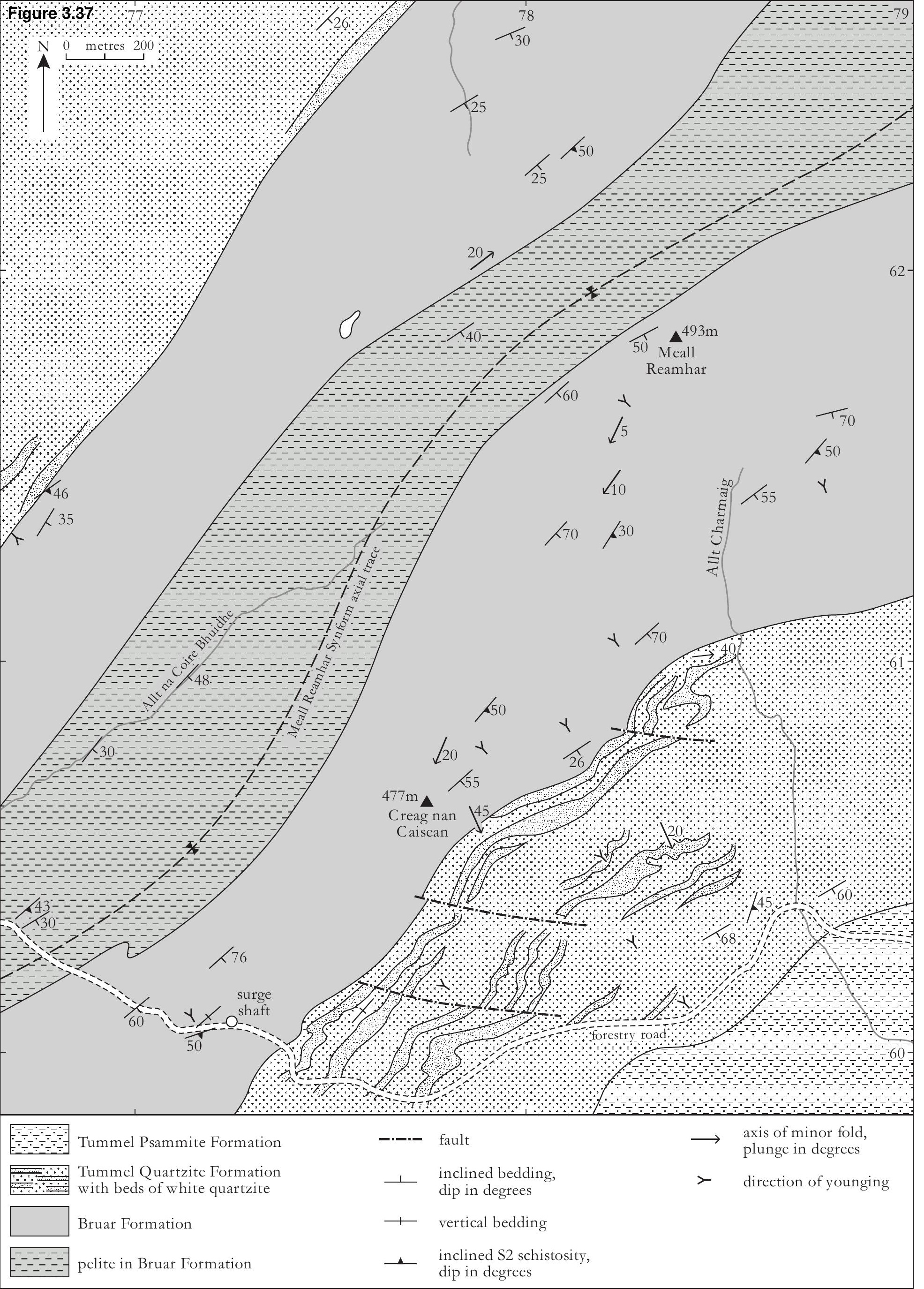




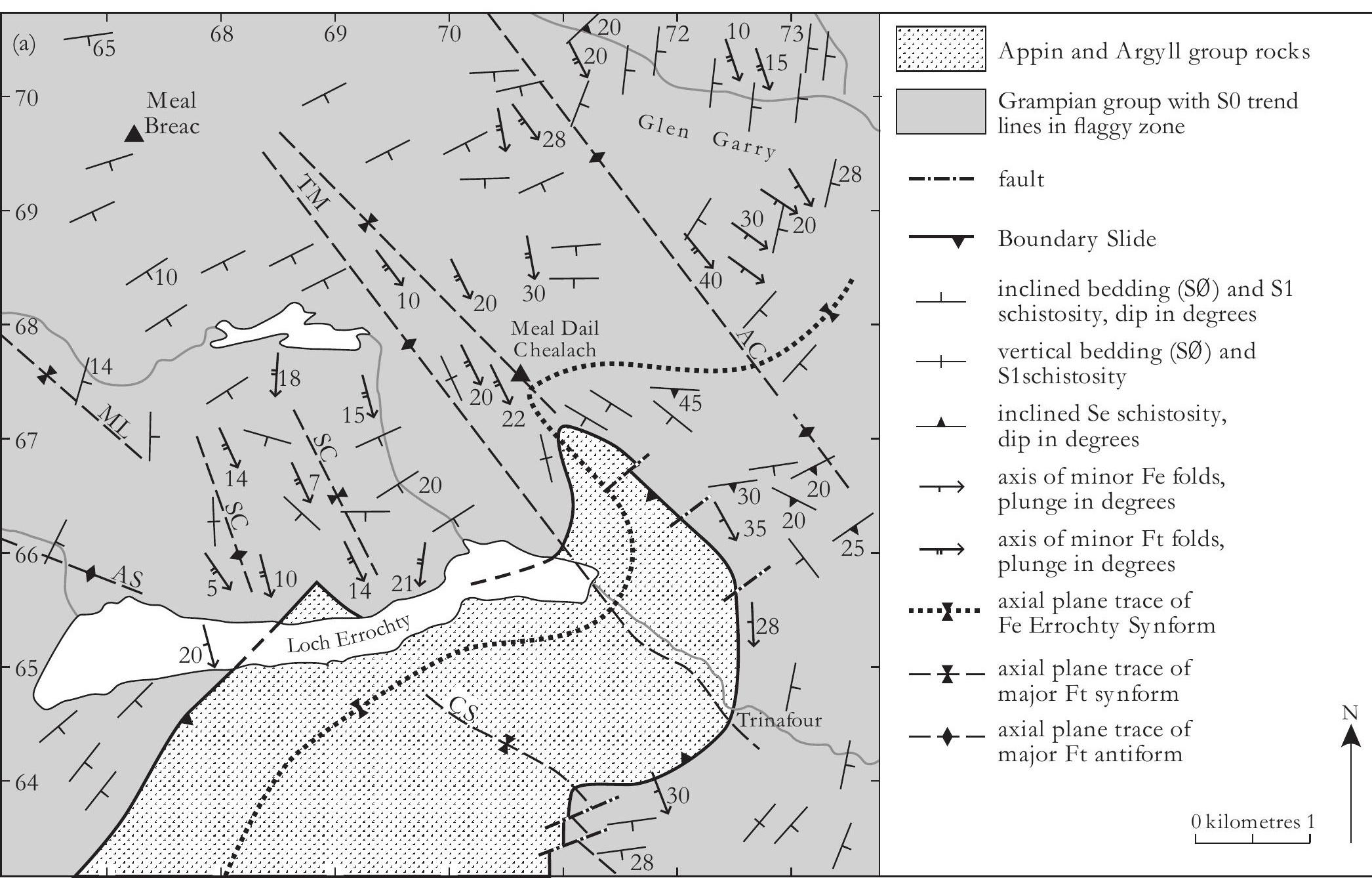


(b)

ENE

WSW

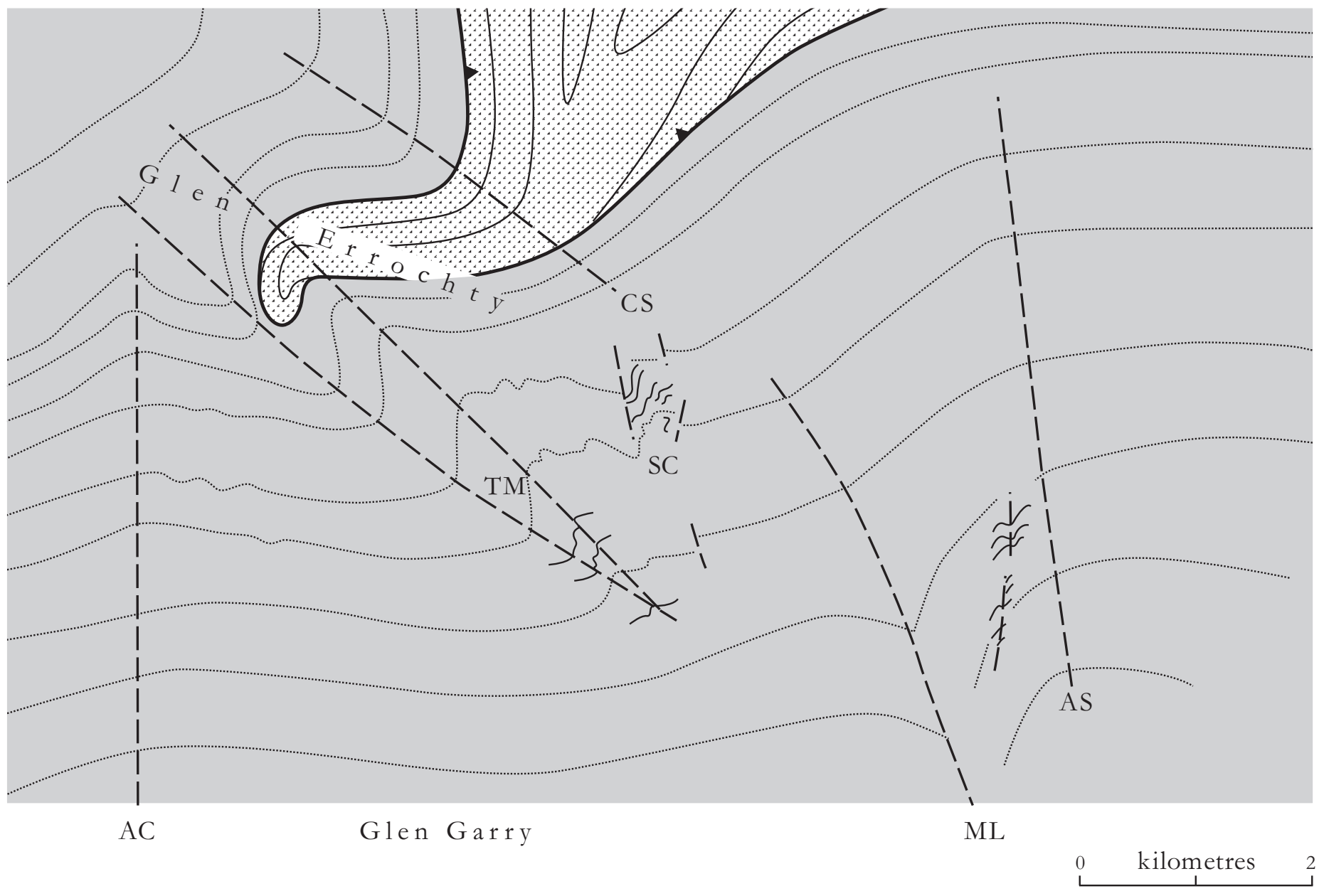


Figure 3.41

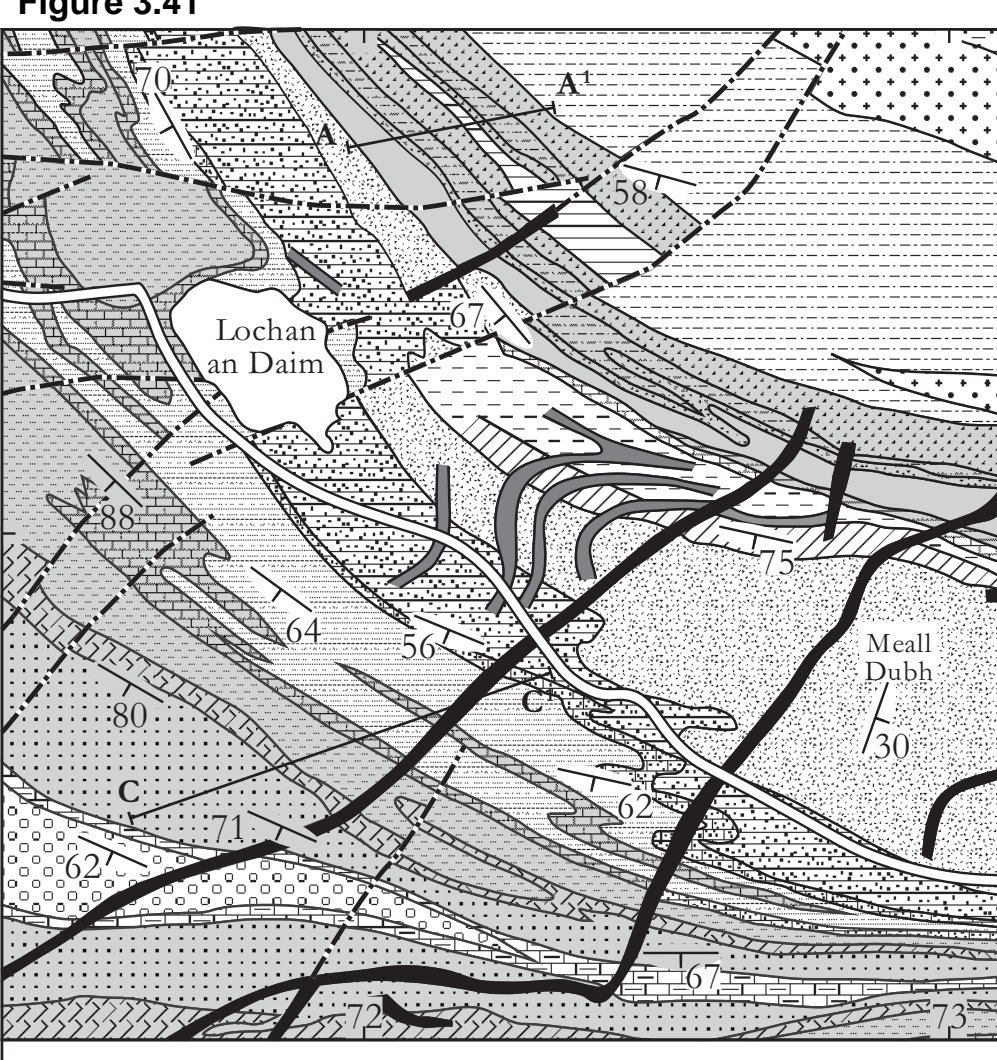

Intrusive igneous rocks

microdiorite dy kes

Metamorphosed intrusive igneous rocks

late amphibolite

\section{Argyll Group}

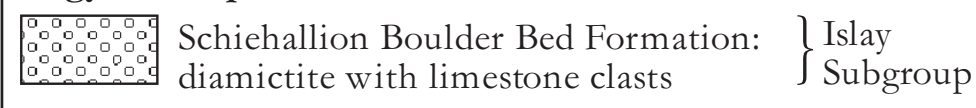

\section{Appin Group}

\section{嚂}

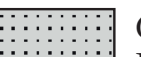

Drumchastle Pale Limestone

Formation: dolomitic metalimestone

Cnoc an Fhithich Banded Semipelite

Formation: banded semipelite

graphitic

metalimestone

graphitic pelite Limestone and

\begin{tabular}{l|l} 
graphitic & Formation
\end{tabular}

metalimestone

Tullochroisk Semipelite Formation:

banded, graphitic semipelite

Strath Fionan Limestone Formation: dolomitic metalimestone

Strath Fionan Pale Banded Semipelite Formation: banded semipelite

$\left.\begin{array}{l}\text { quartzite } \\ \text { transitional facies }\end{array}\right\} \begin{aligned} & \text { Meall Dubh } \\ & \text { Quartzite } \\ & \text { Formation }\end{aligned}$

Meall Dubh Graphitic Schist

Formation: graphitic pelite

Meall Dubh Limestone Formation: metalimestone
Blair Atholl

Subgroup

Ballachulish

Subgroup

\section{葭}

\section{E}

Meall Dubh Striped Pelite Formation: striped semipelite

Beoil Schist Formation: micaceous pelite

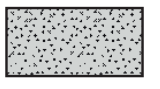

Beoil Quartzite Formation: quartzite

Lochaber

Subgroup
Dunalastair Semipelite Formation: semipelite

Dunalastair Quartzite Formation: quartzite

\section{Grampian Group}

E undivided psammite

Kynachan Psammite Formation:
psammite

$\because \because \because \because *$ Ky nachan Quartzite Formation:

Glen Spean

Subgroup

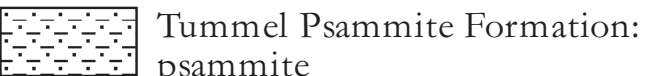

-.-1- fault

( ) 


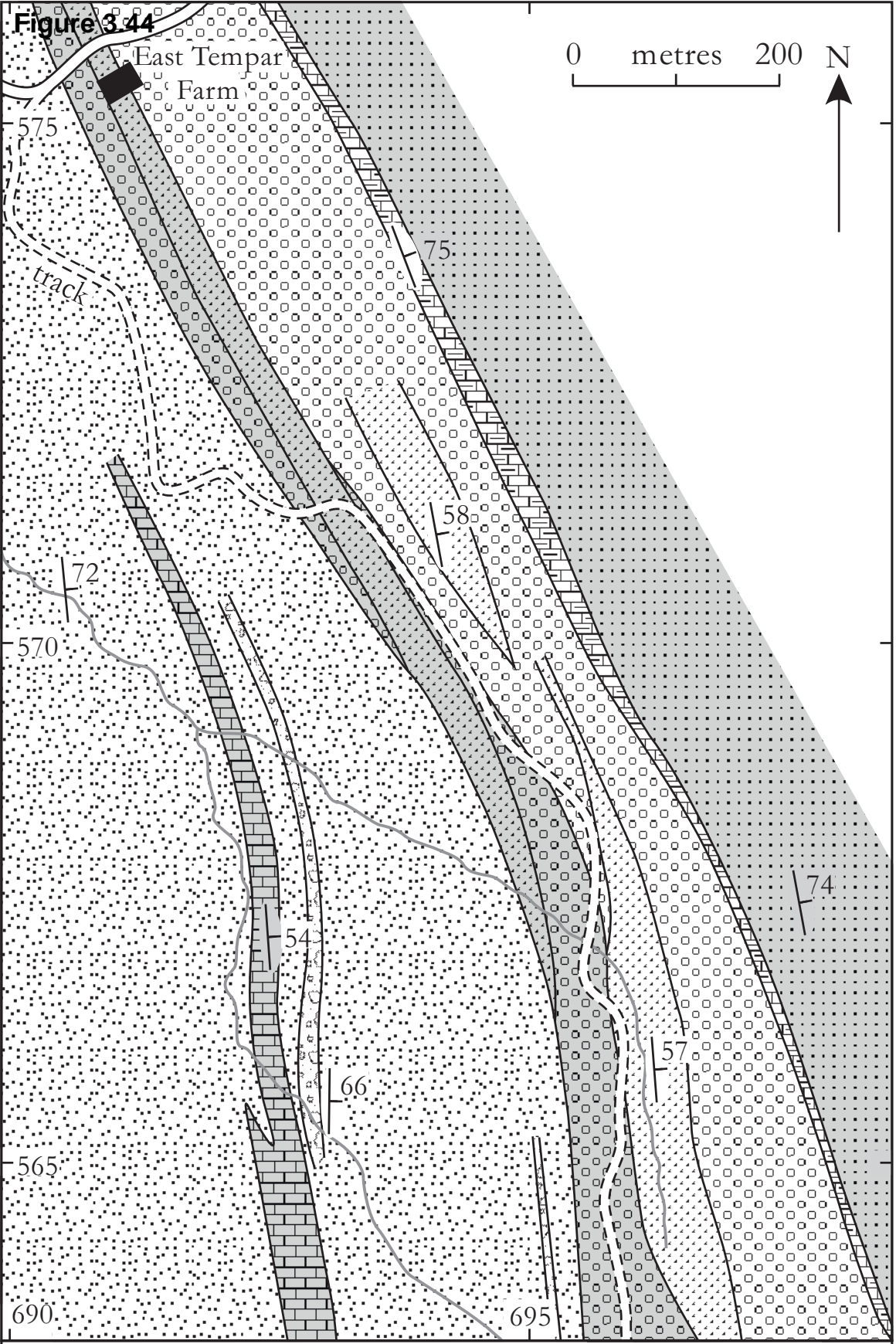

\section{Islay Subgroup}

\section{臣}

\section{㞔}

\section{Blair Atholl Subgroup}

屋

Drumchastle Pale Limestone Formation

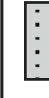

Cnoc an Fhithich Banded Semipelite Formation

$ـ \quad$ inclined bedding, dip in degrees 
Figure 3.46

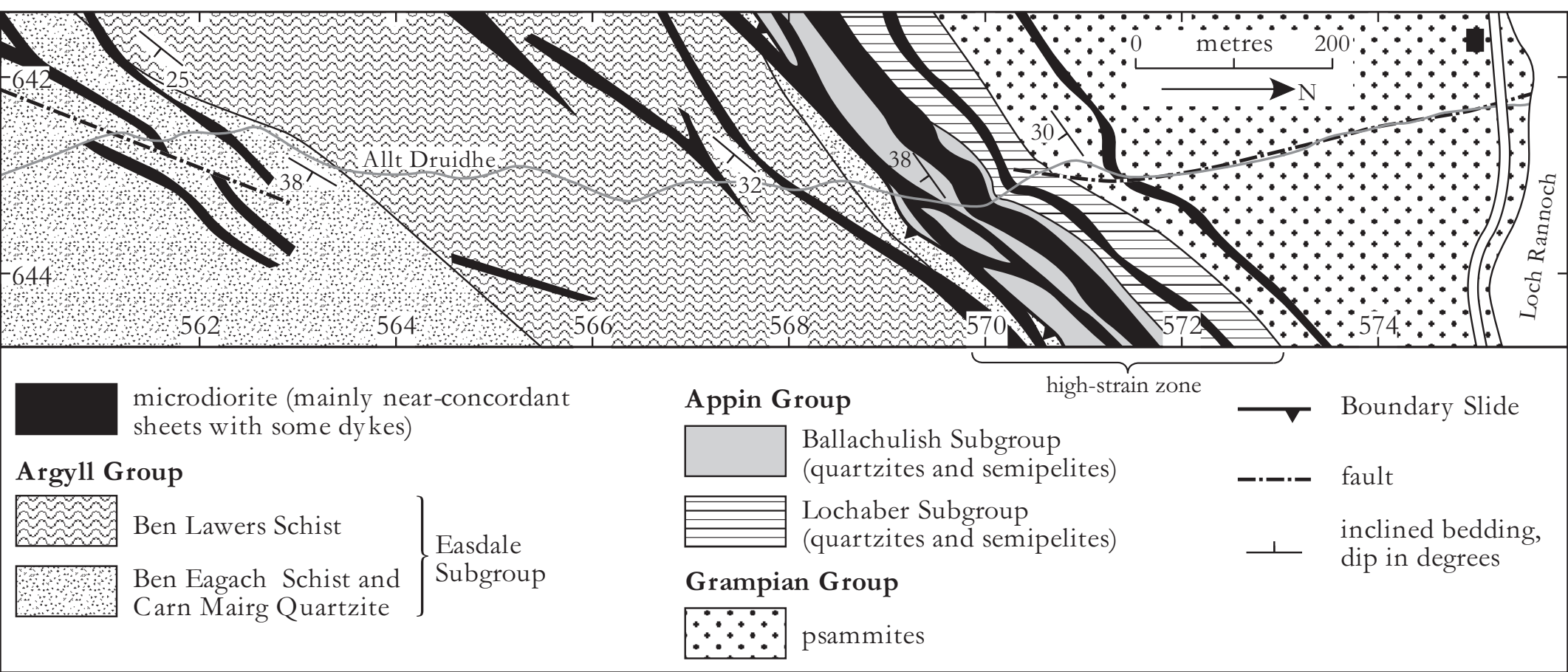


amphibolite

\section{Crinan Subgroup}

\section{Men Lui Schist}

\section{Easdale Subgroup}

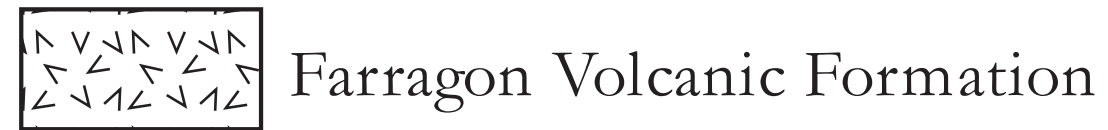

2adid Ben Lawers Schist with

Ben Eagach Schist

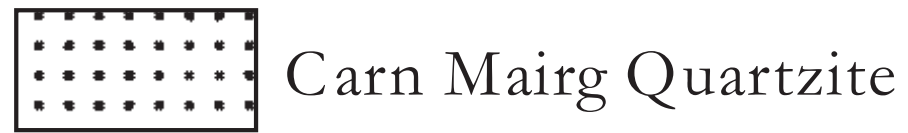

ー・ー・ fault

1 inclined bedding, dip in degrees

? be overturned, dip in degrees

$\leftarrow \quad$ vertical bedding

2 axis of F2 minor fold or bedding/S2 cleavage

$\stackrel{2}{\mathrm{~V}}$ intersection, plunge in degrees (flag shows direction of vergence)

$\stackrel{4}{\mathrm{~V}} \quad$ axis of F4 minor fold, plunge in degrees (flag shows direction of vergence) inclined axial plane of F4 minor fold, dip in degrees

$-\vdash-$ axial plane trace of major antiform 
Figure 3.51

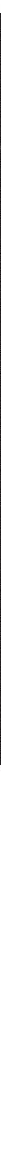









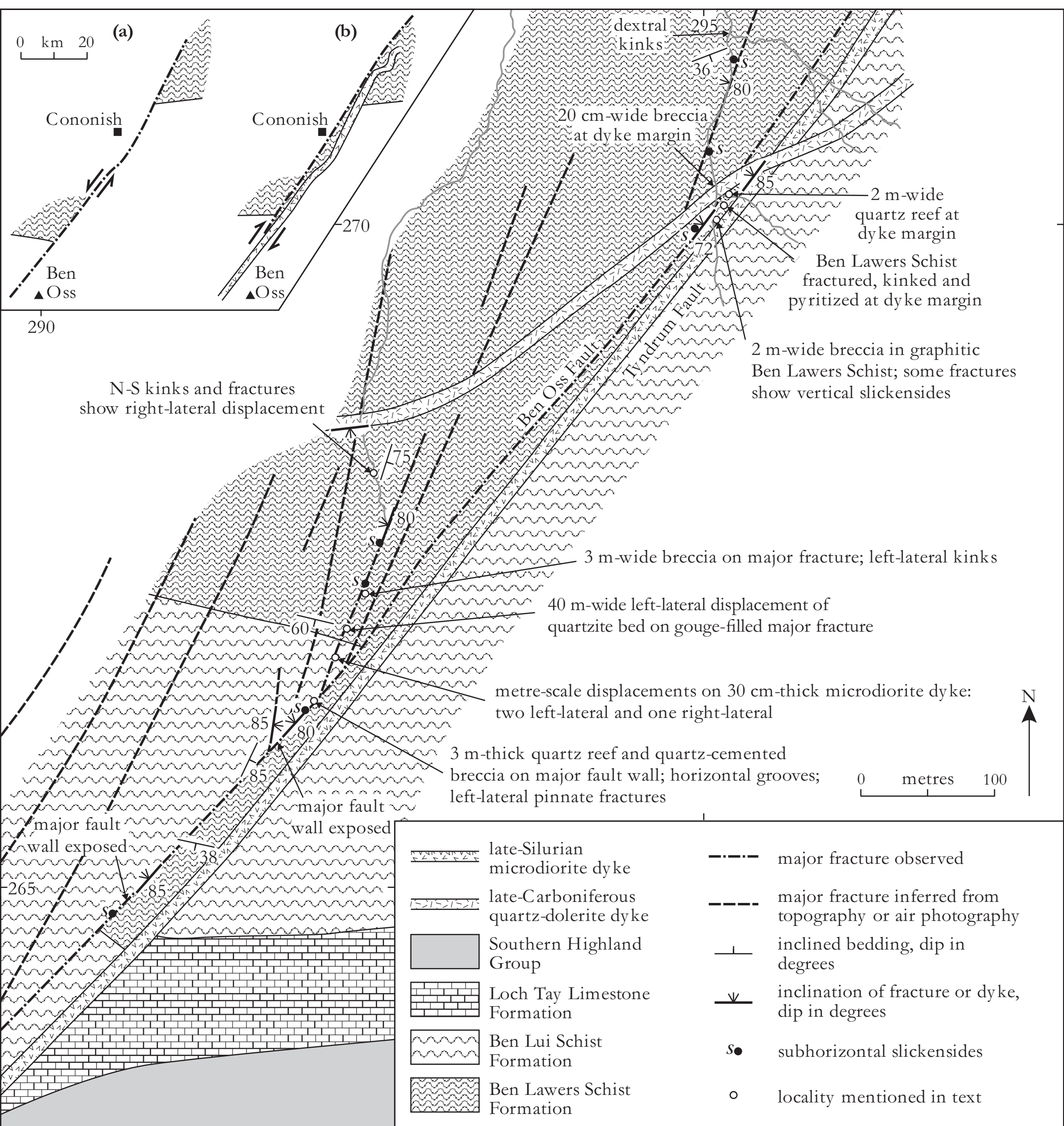




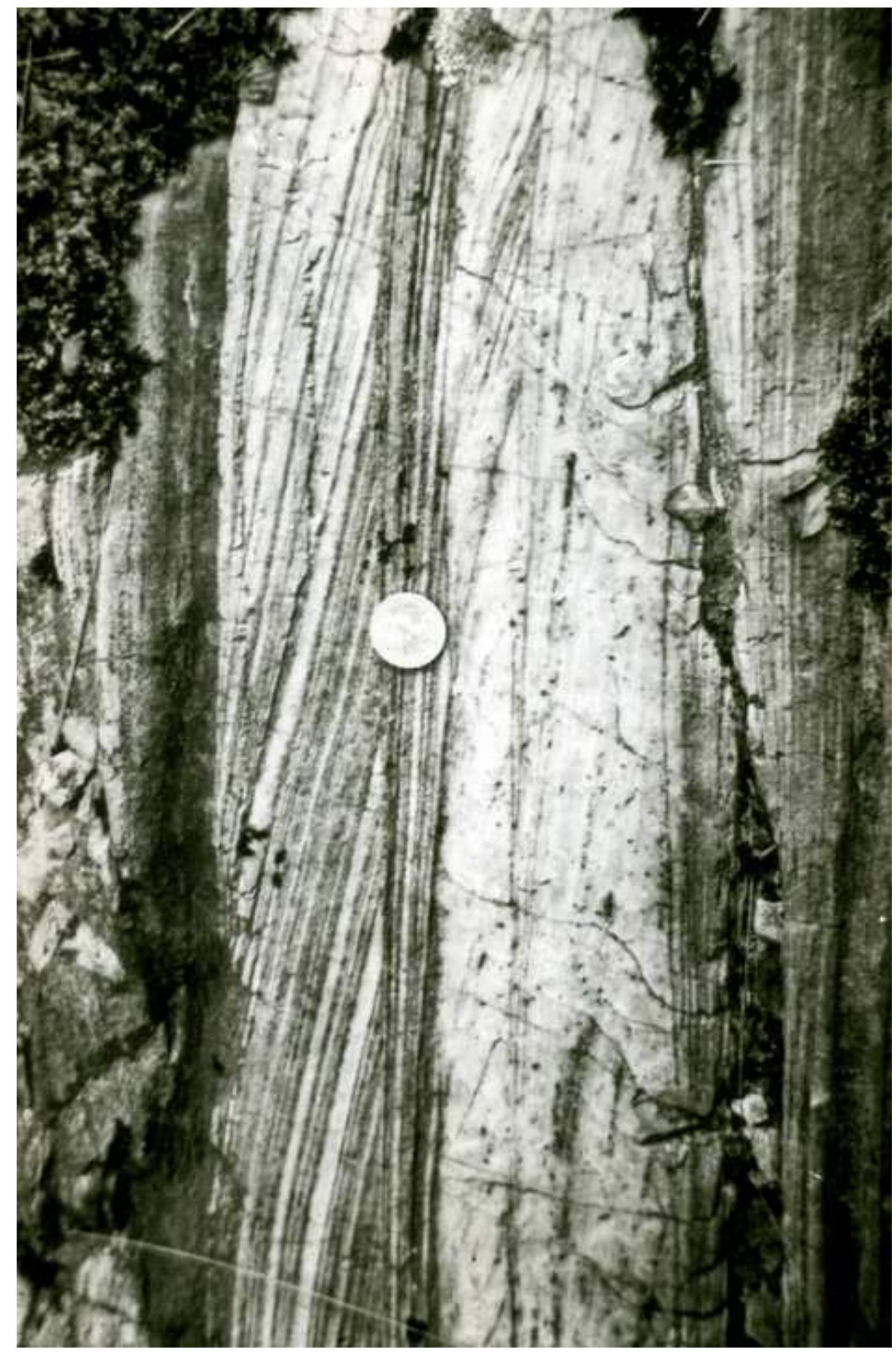


Figure 3.8 colour
Click here to download high resolution image

Figure 3.8 colour
Click here to download high resolution image

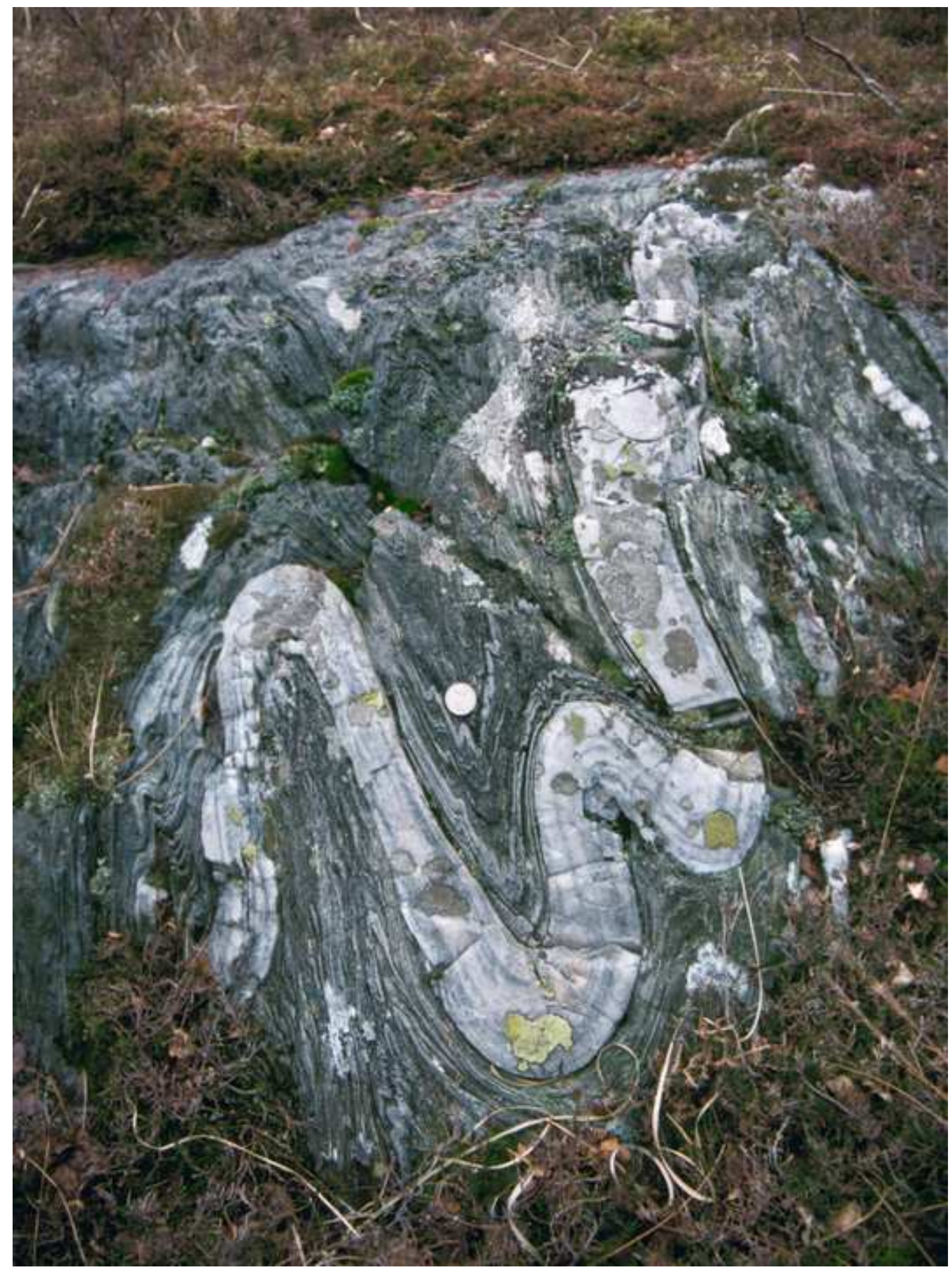




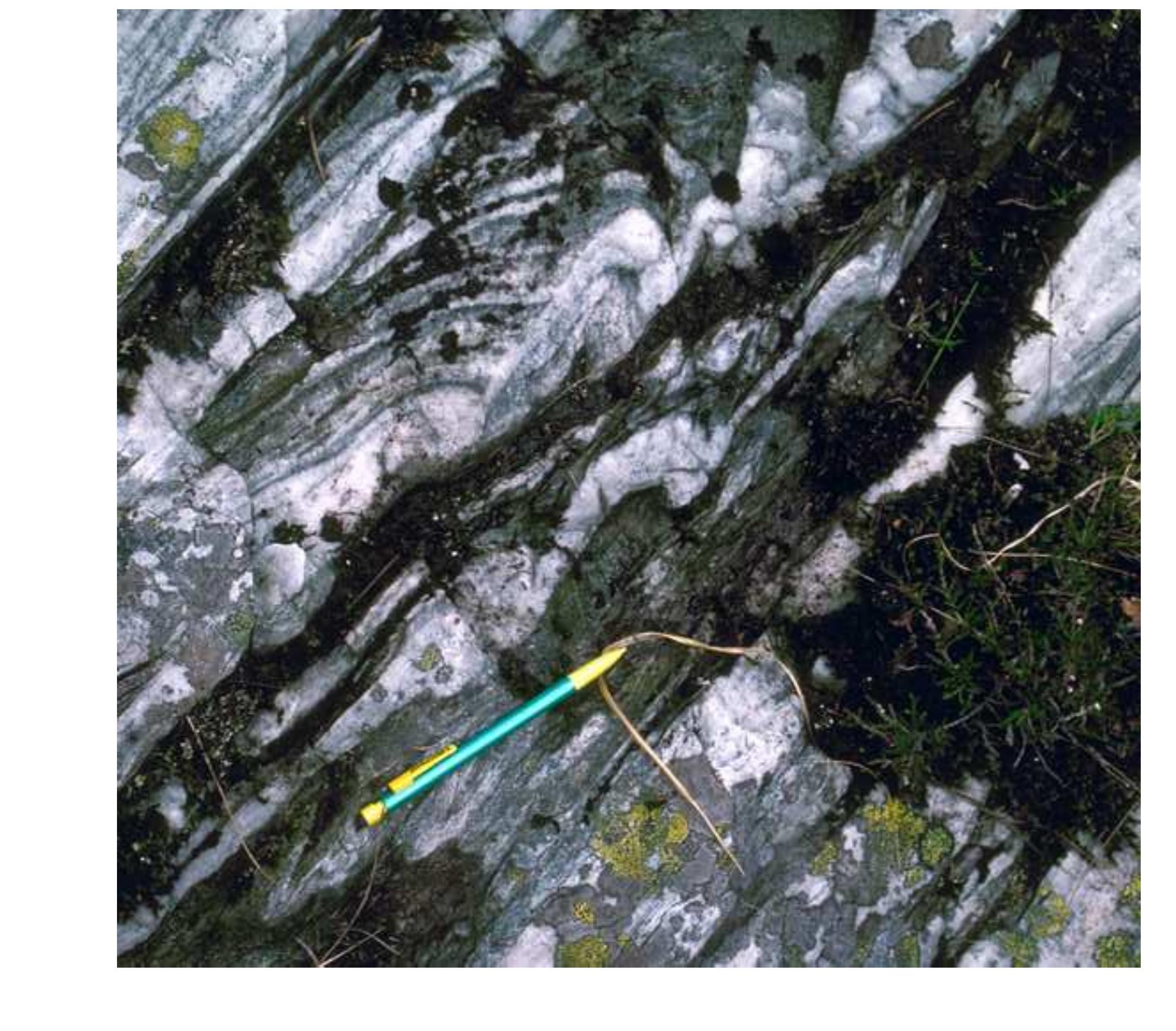

\section{Click here to download high resolution image \\ (n)}

.
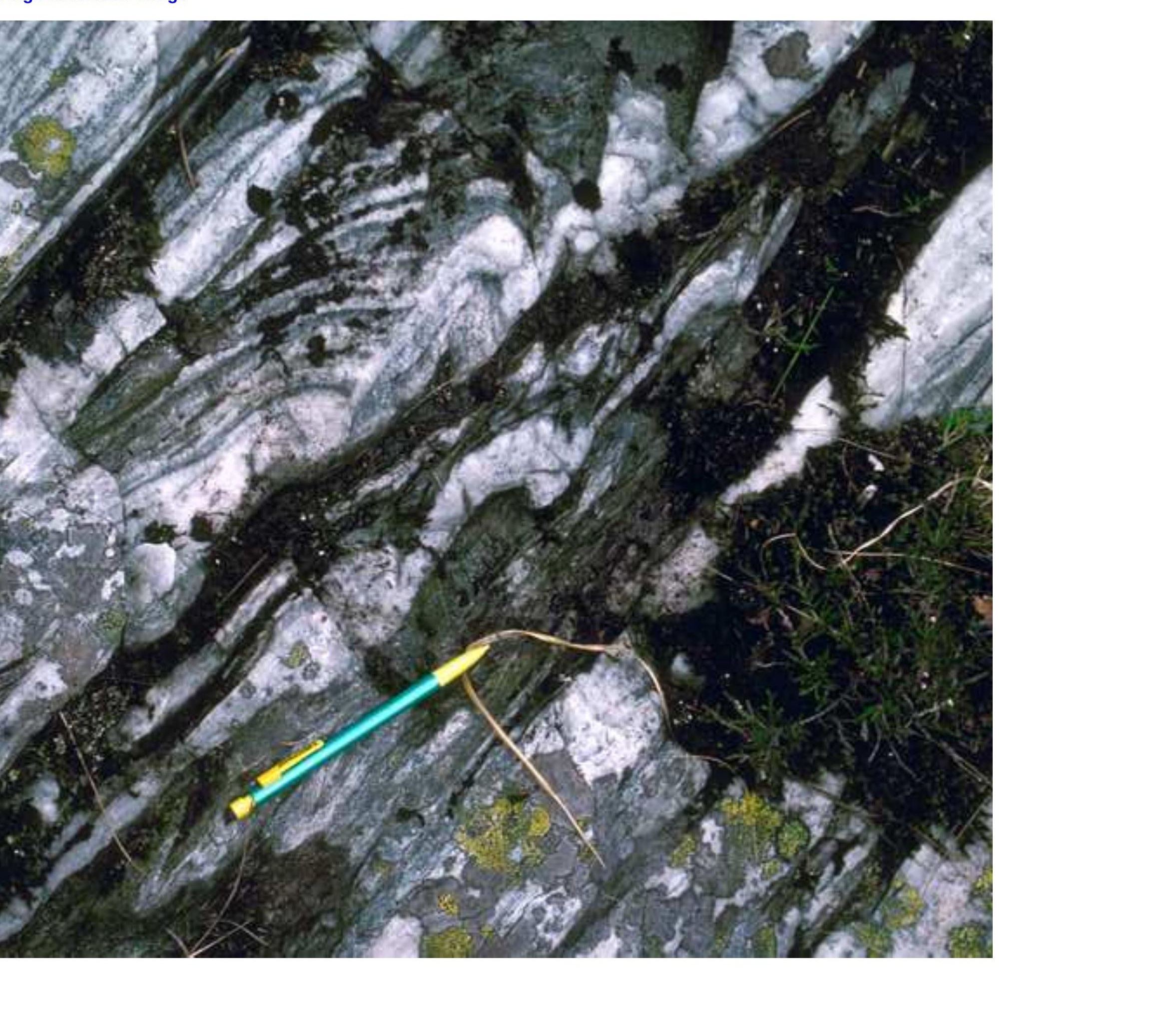
Figure 3.11 colour
Click here to download high resolution imag

Figure 3.11 colour
Click here to download high resolution image

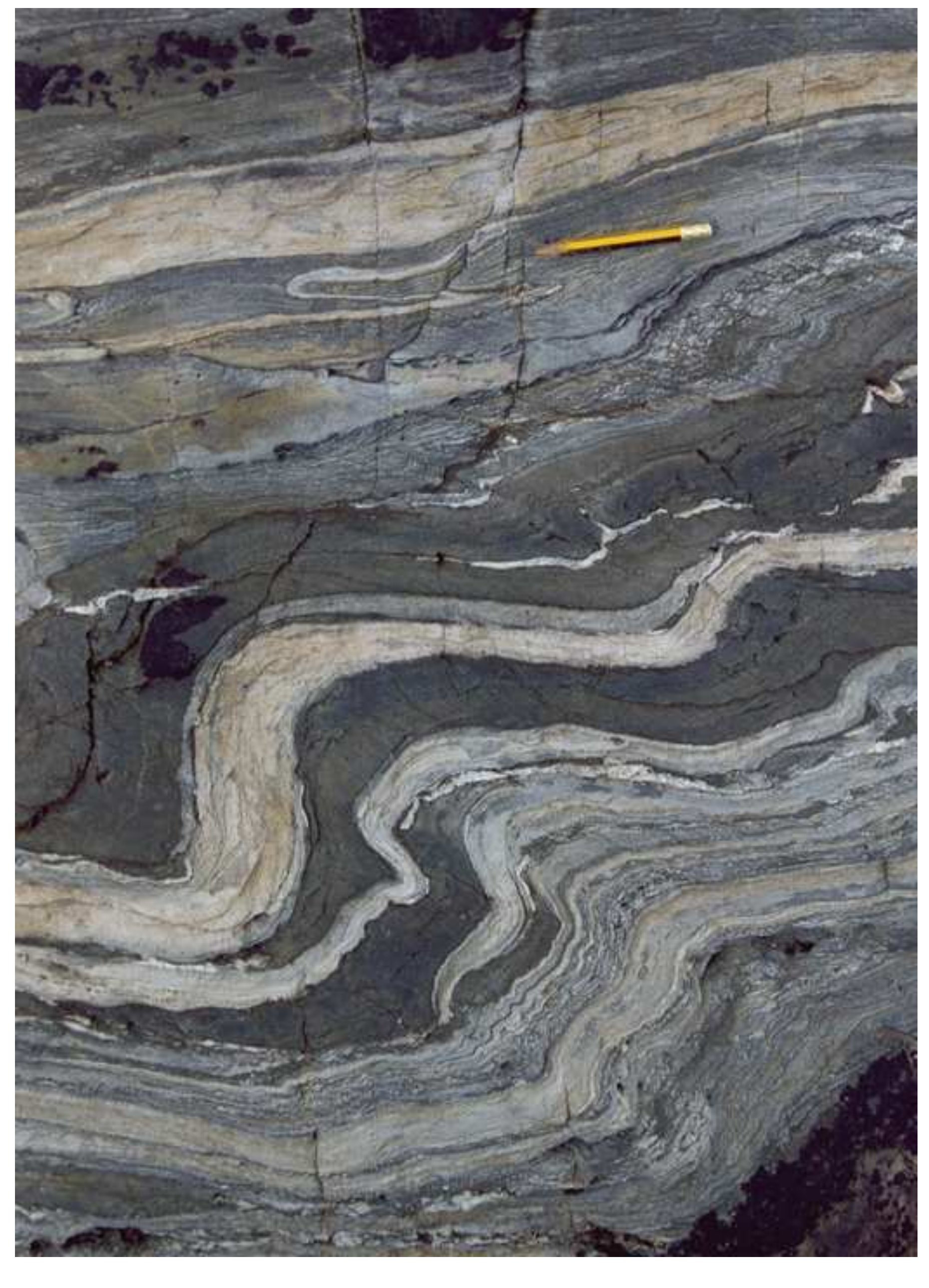




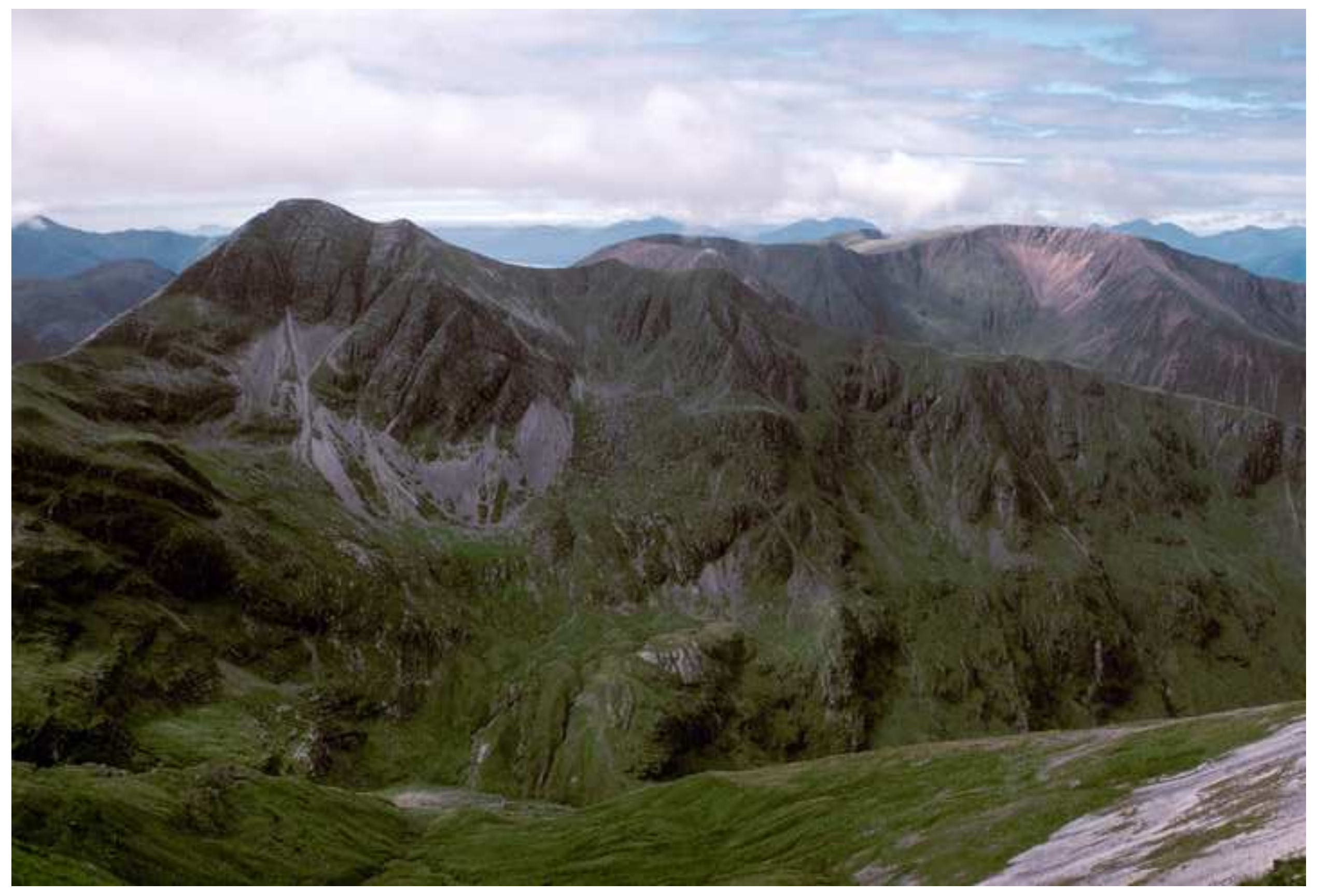


Figure 3.16 colour

Click here to download high resolution image

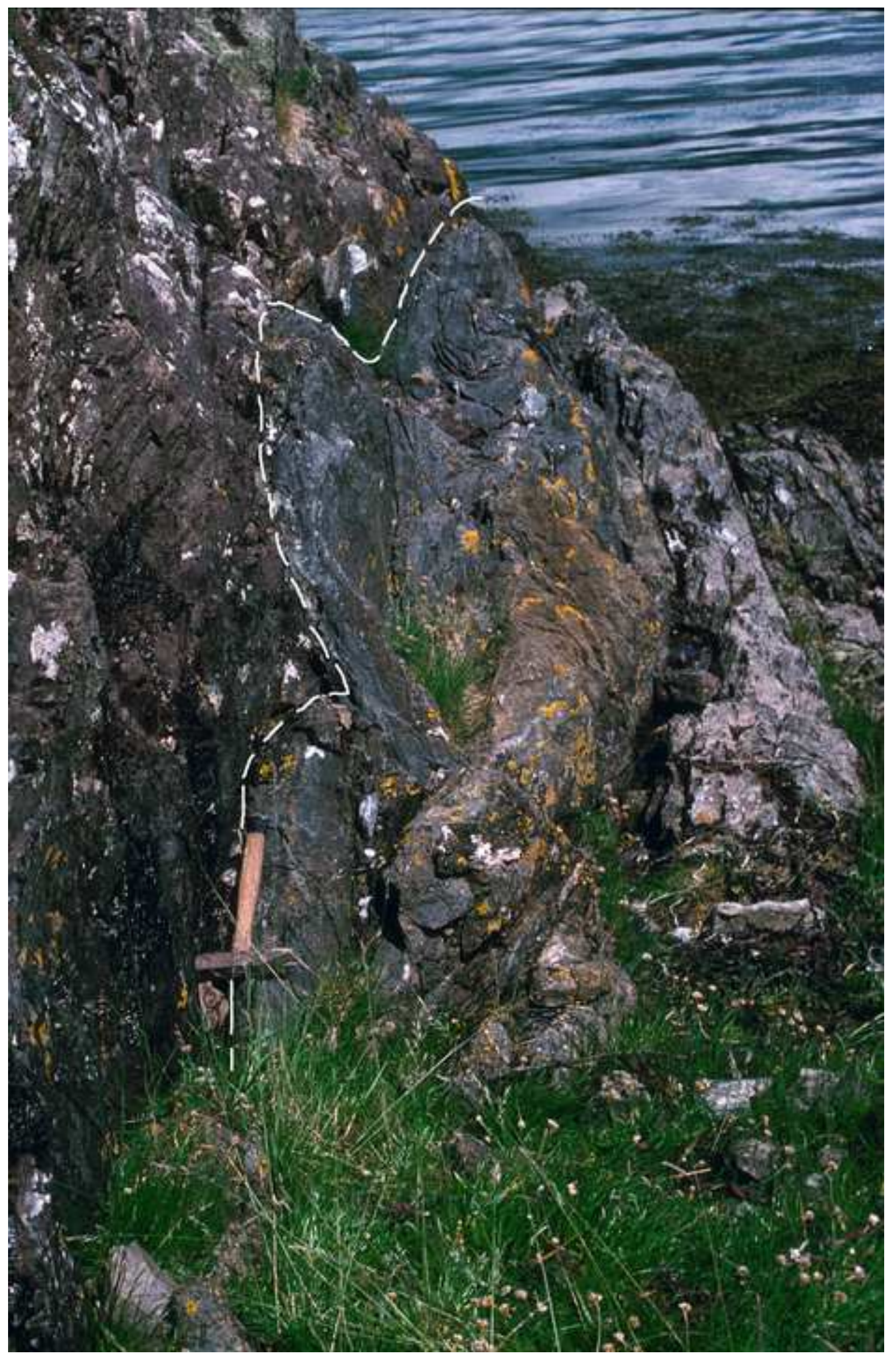




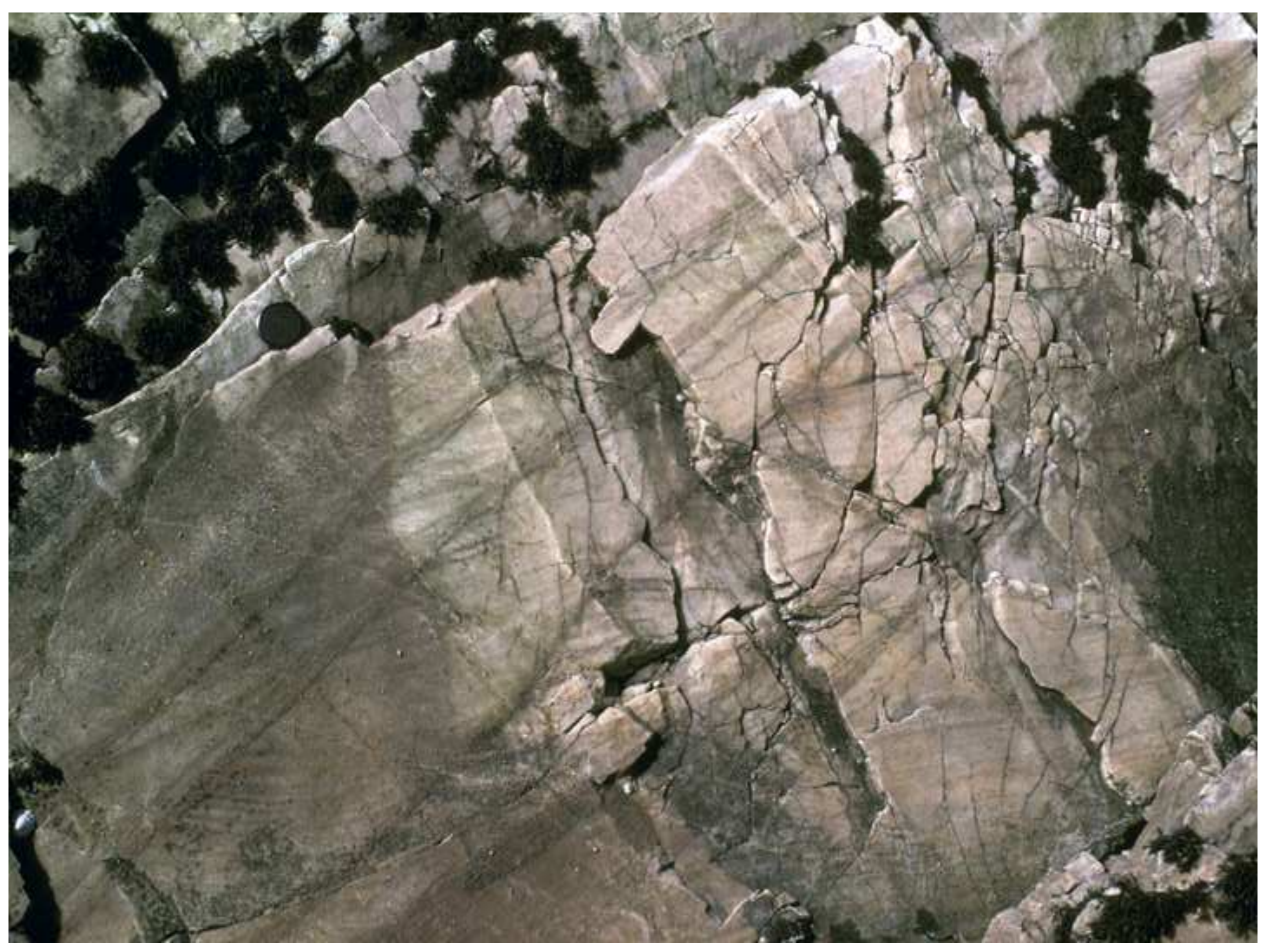

\section{Click here to download high resolution image}


Click here to download high resolution image

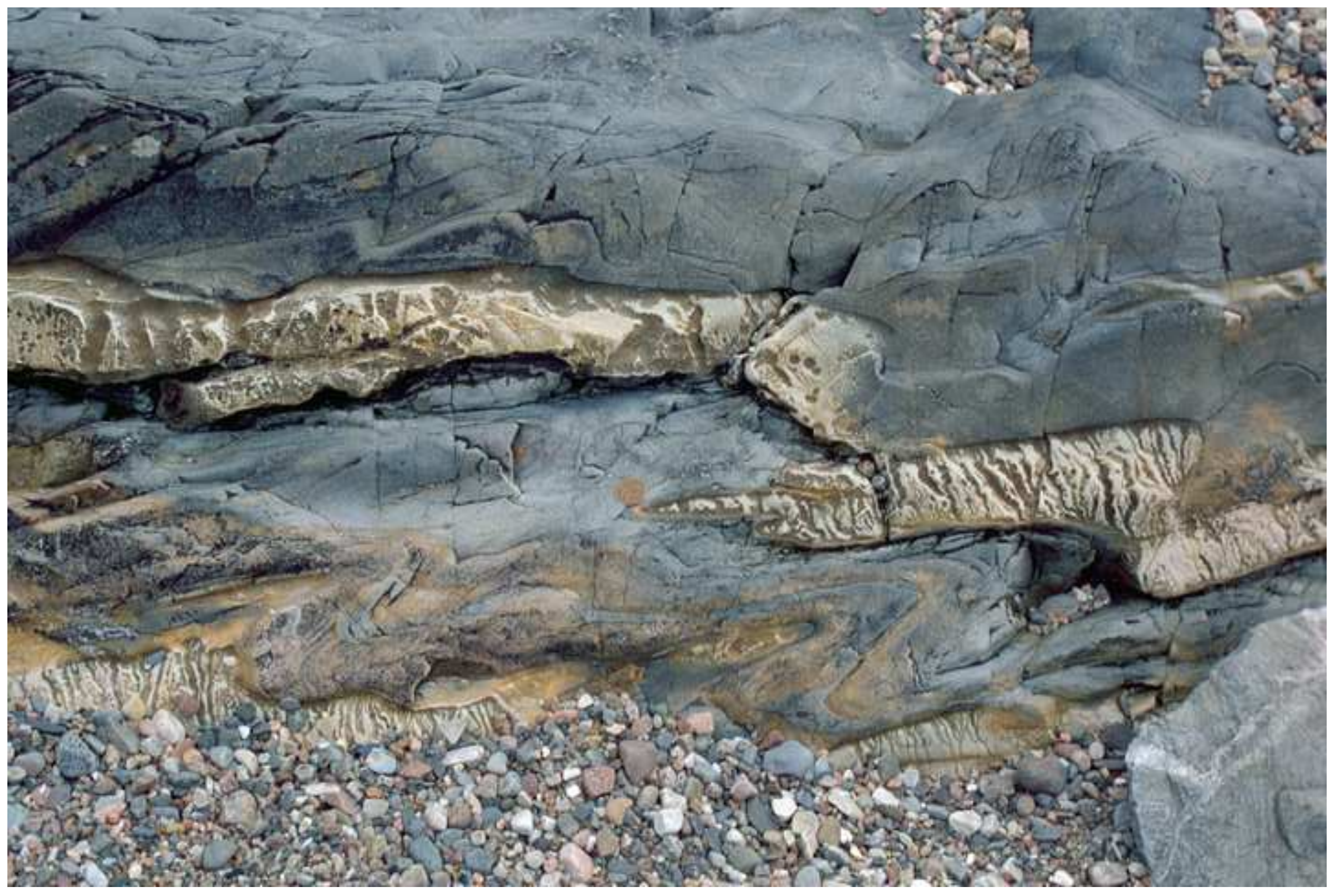


Figure 3.21a colour

Click here to download high resolution image

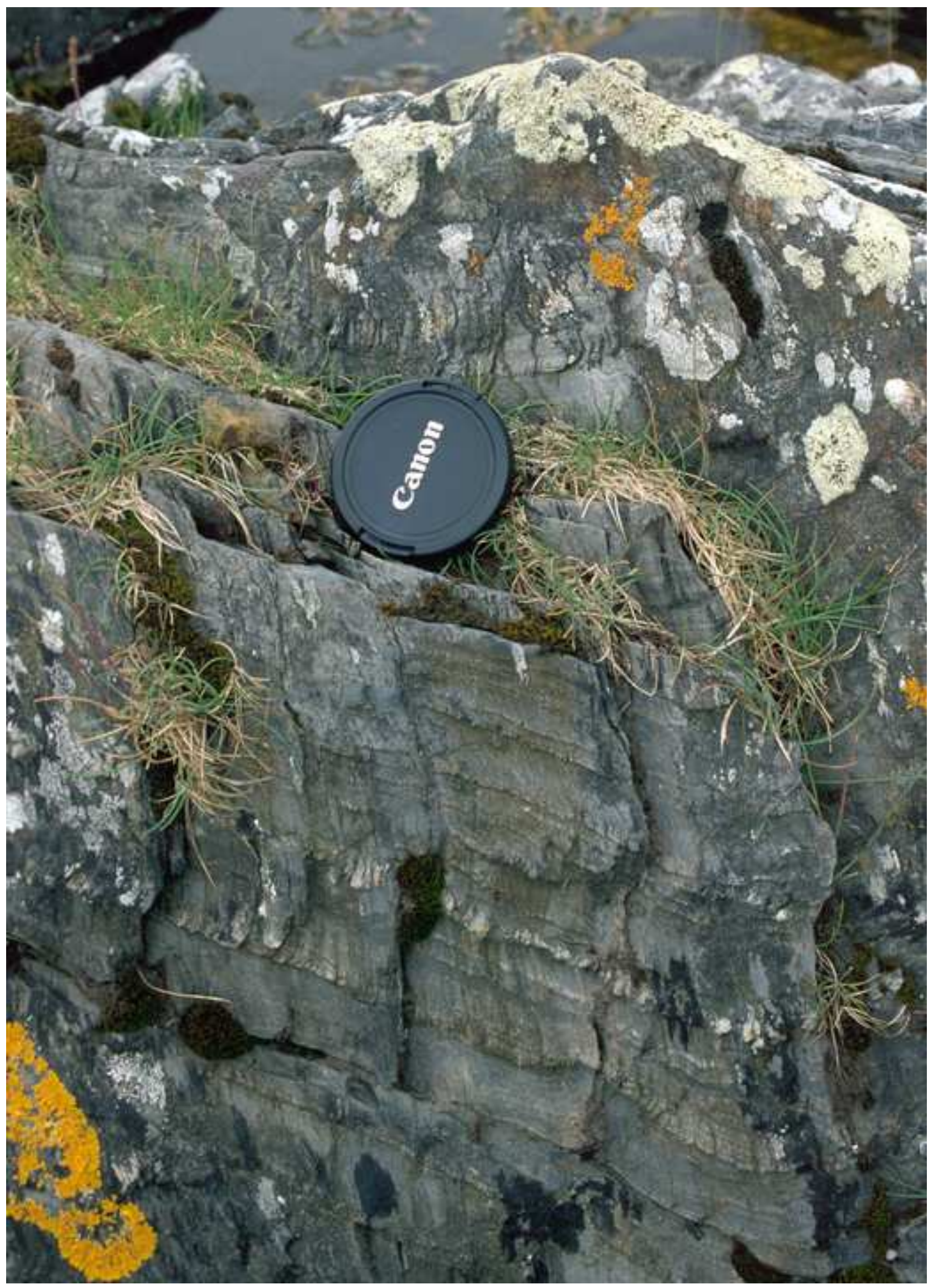


Click here to download high resolution image

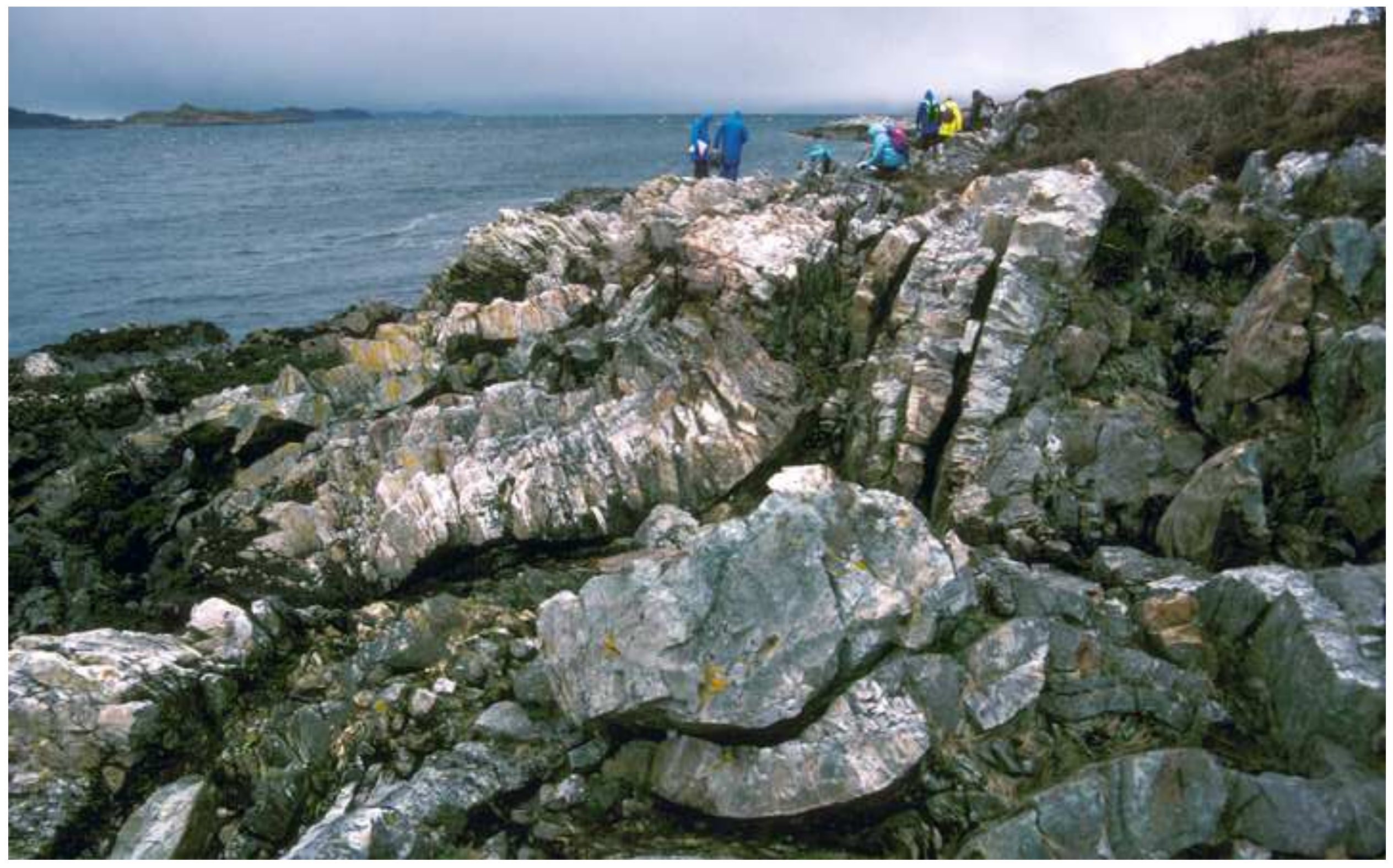


Click here to download high resolution image

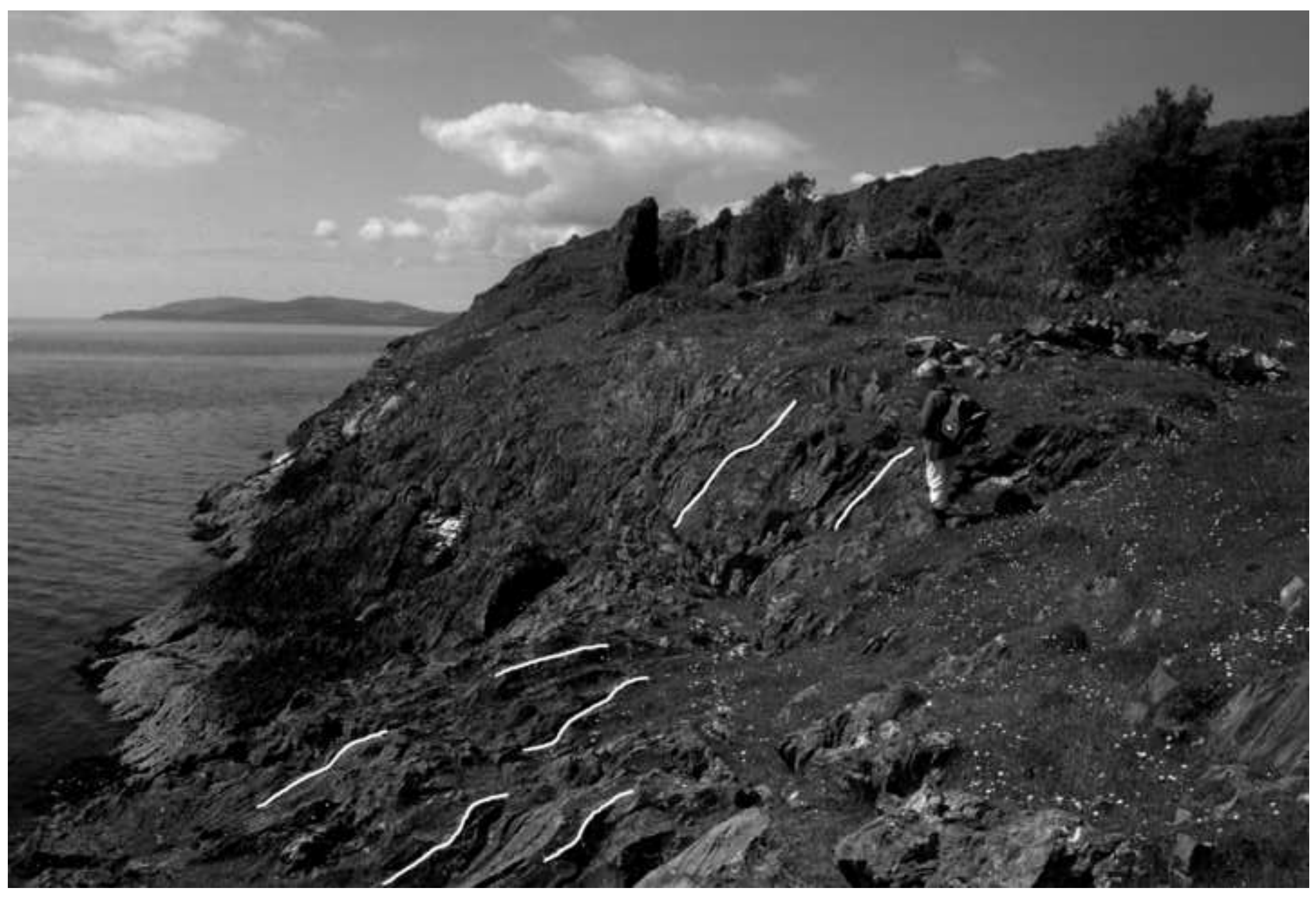


Click here to download high resolution image

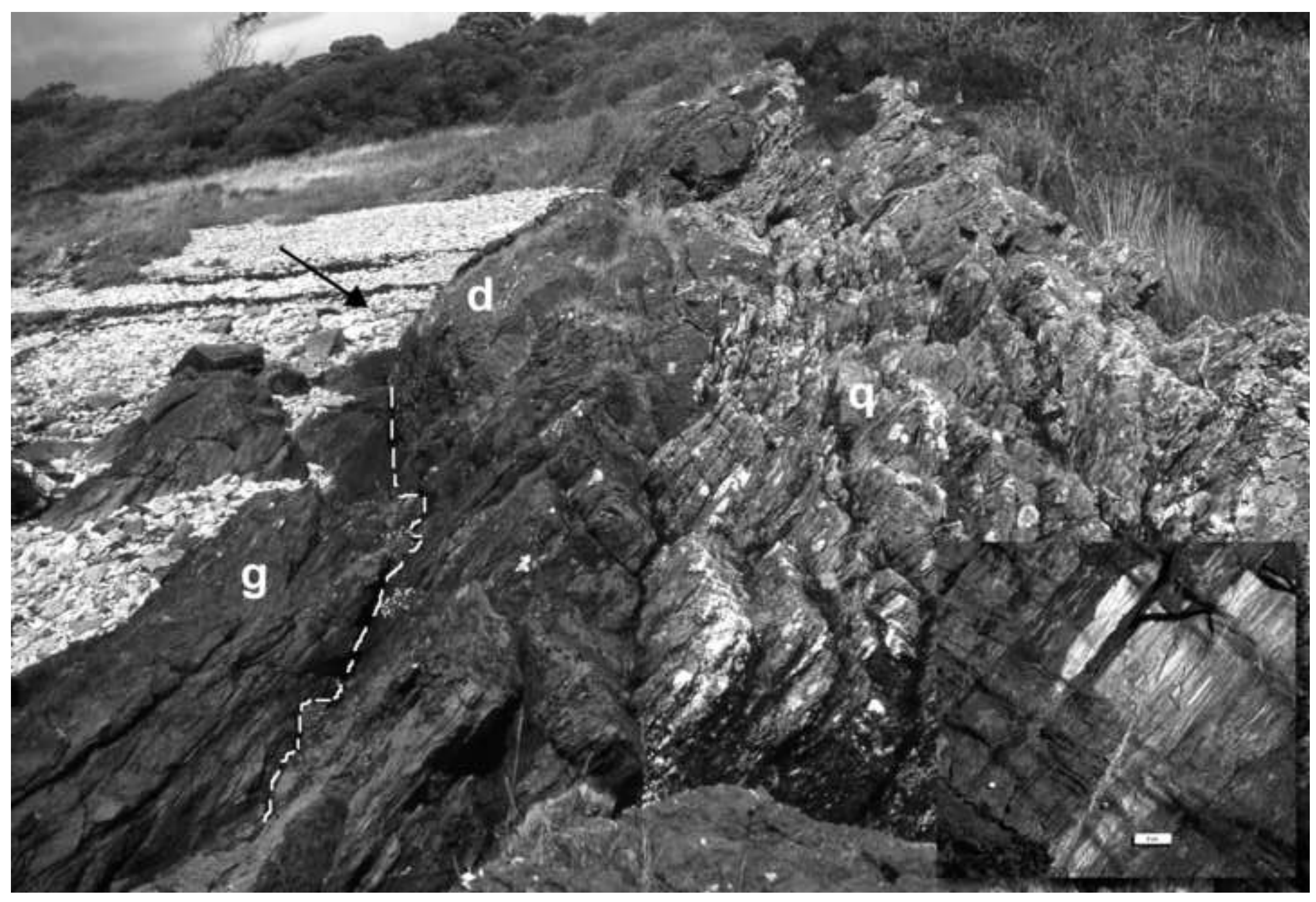




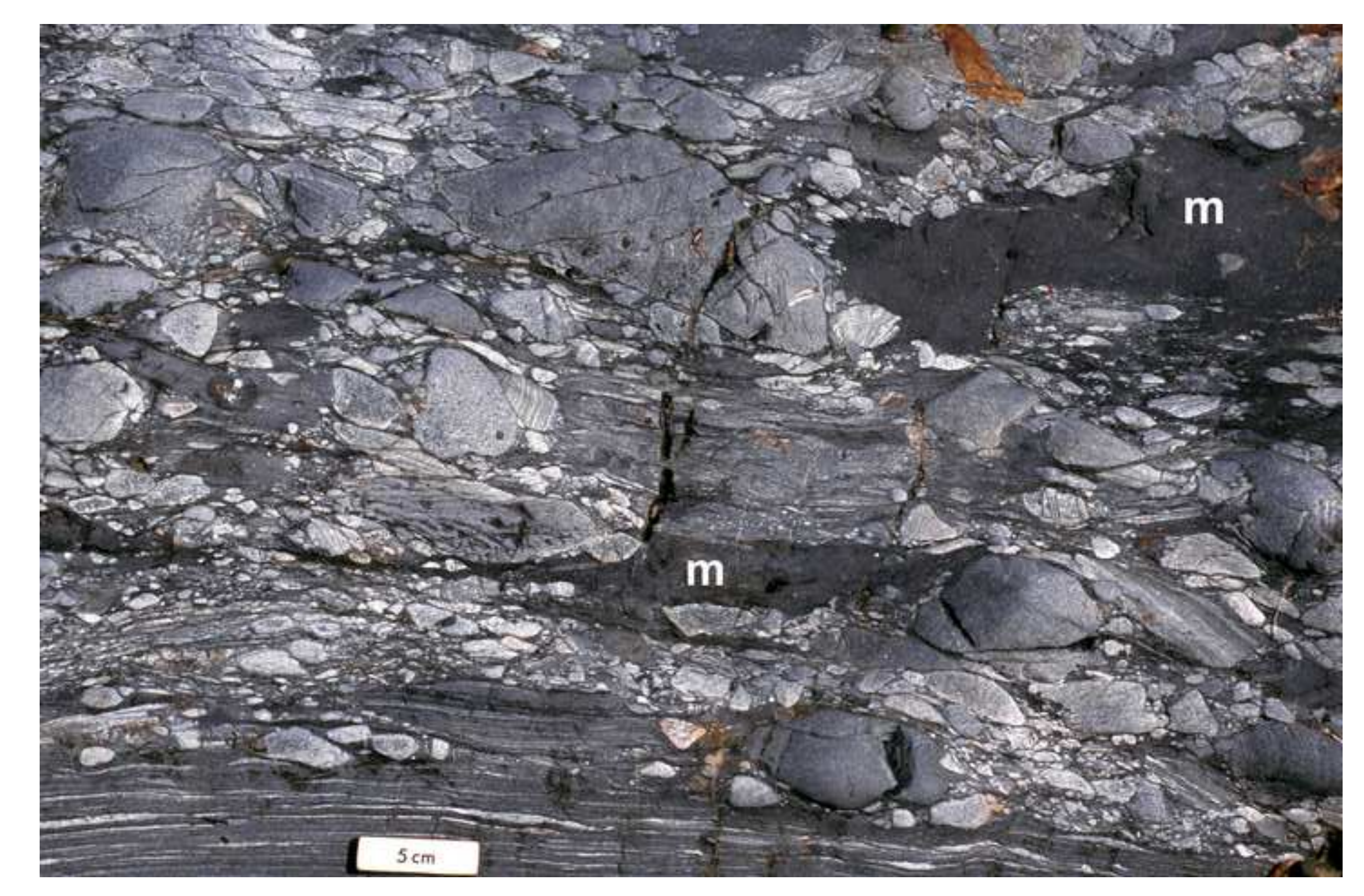




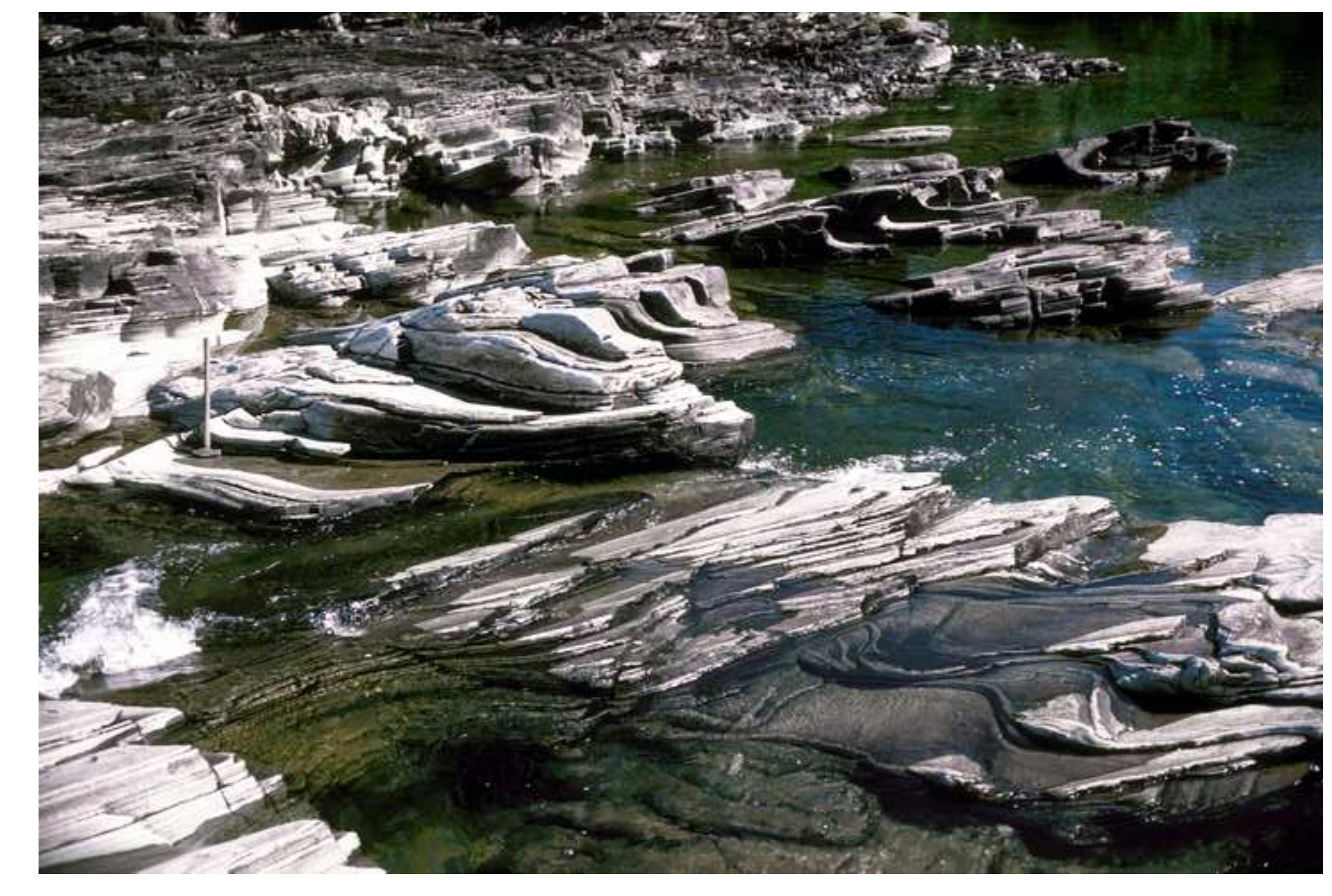




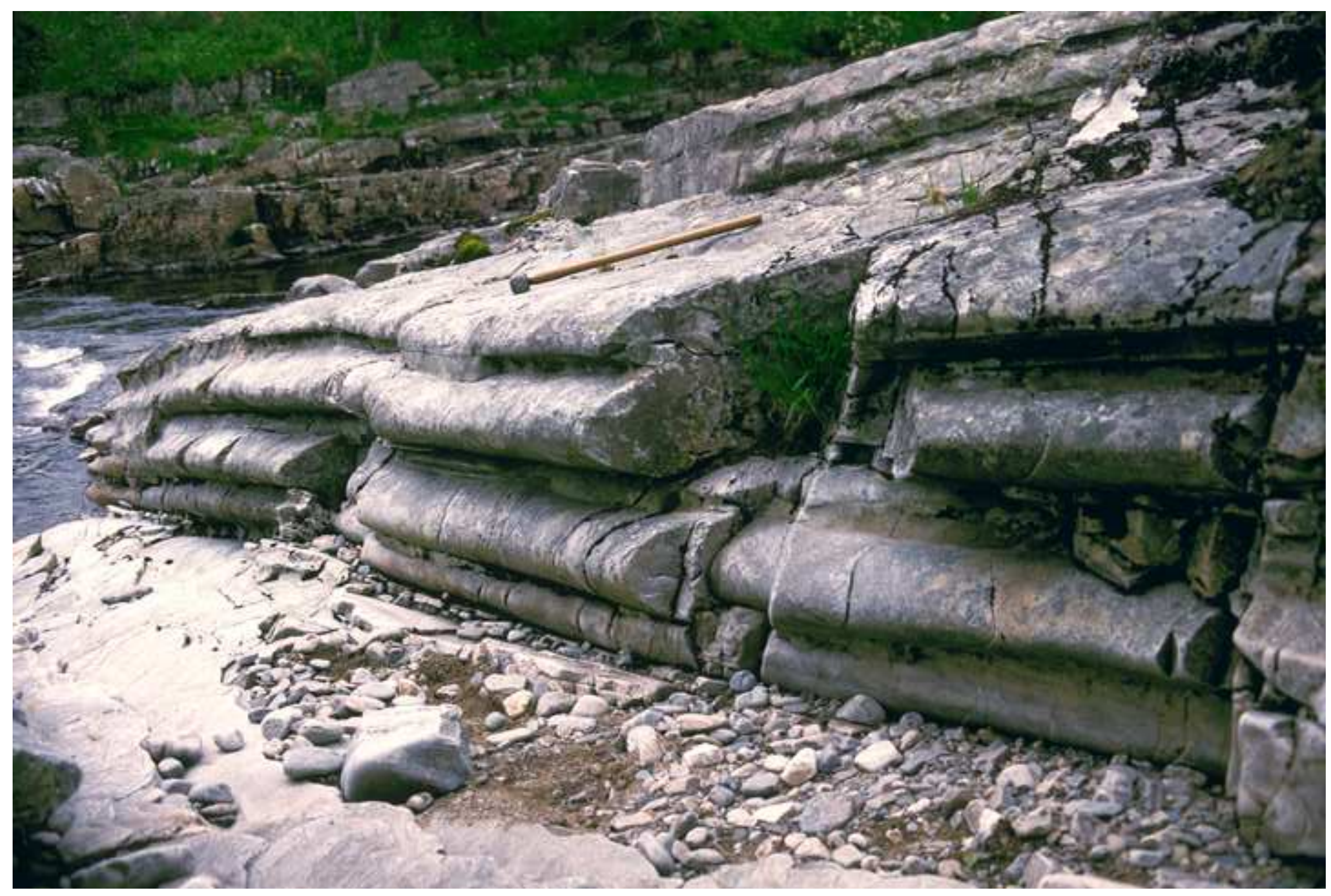


Click here to download high resolution image

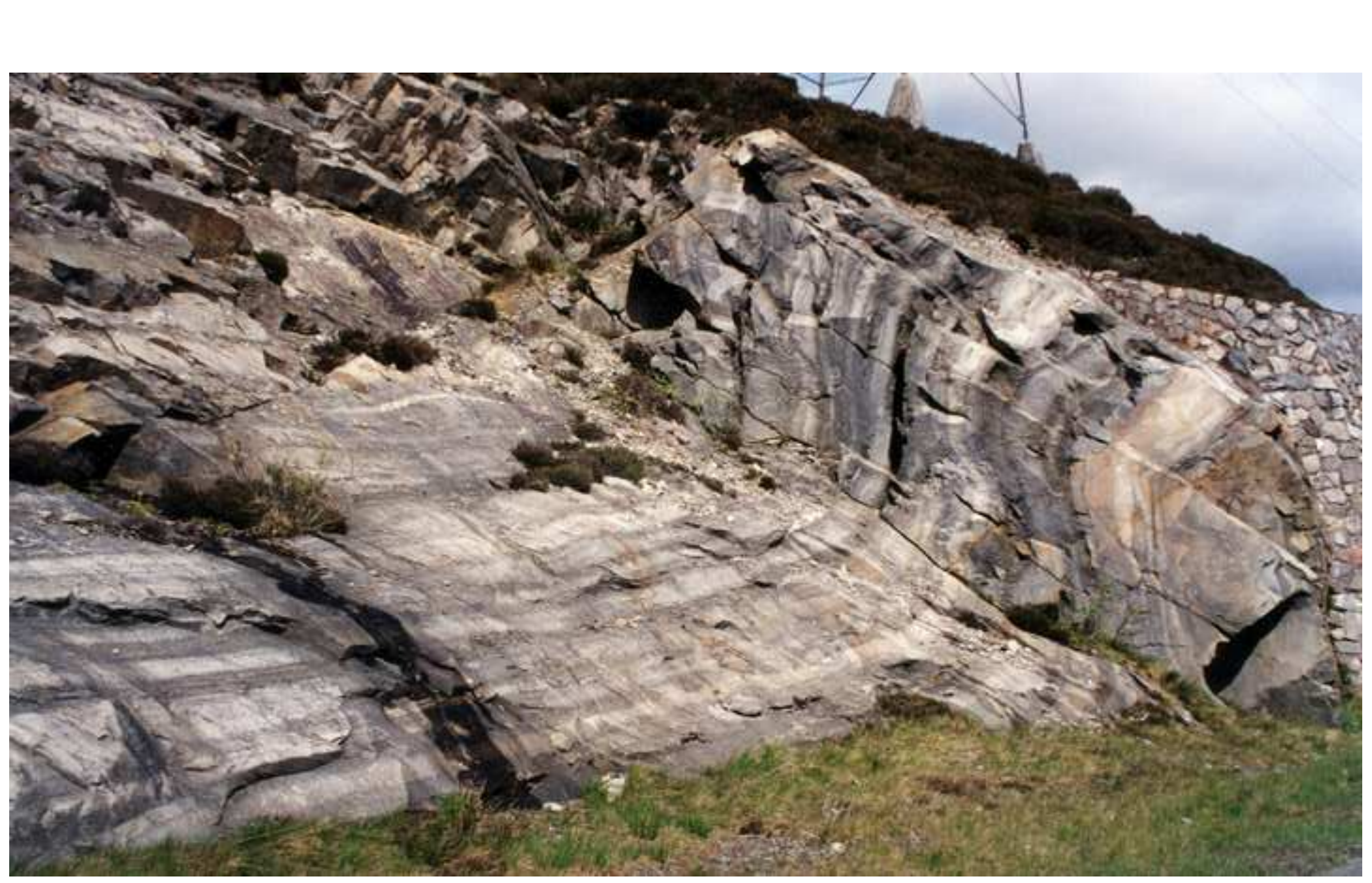

(1)

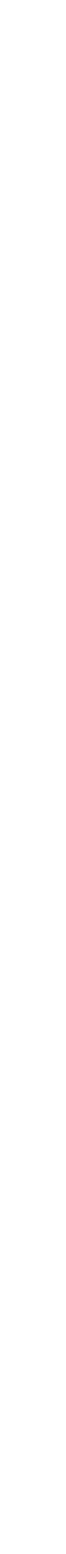


Click here to download high resolution image

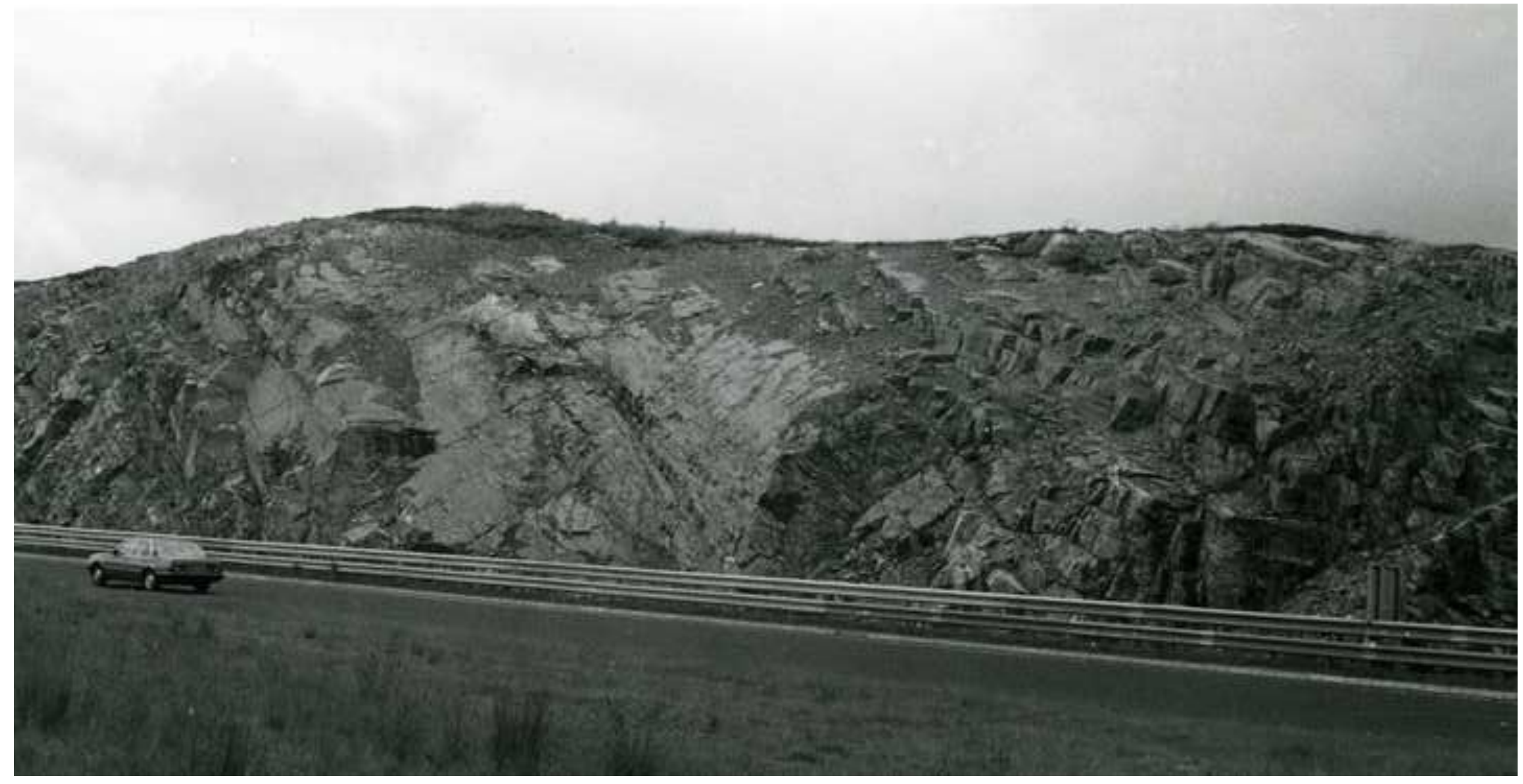


Click here to download high resolution image
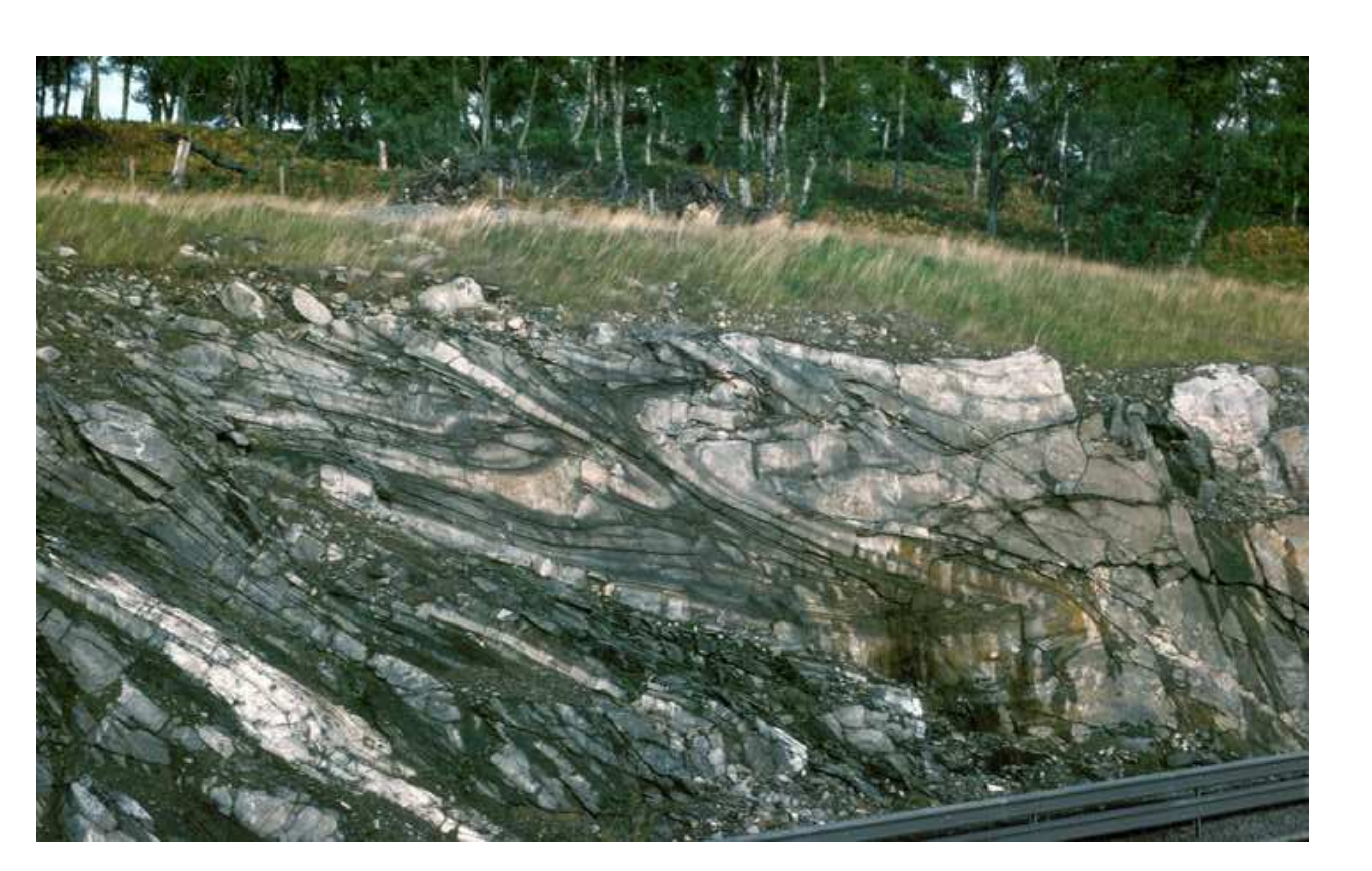

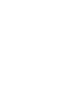

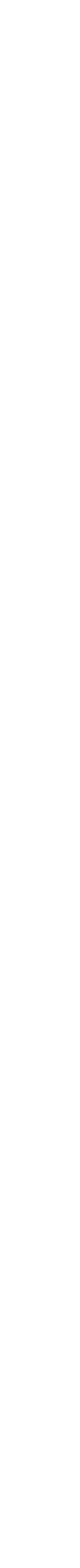

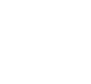

(

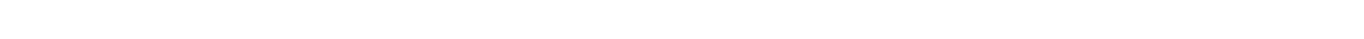




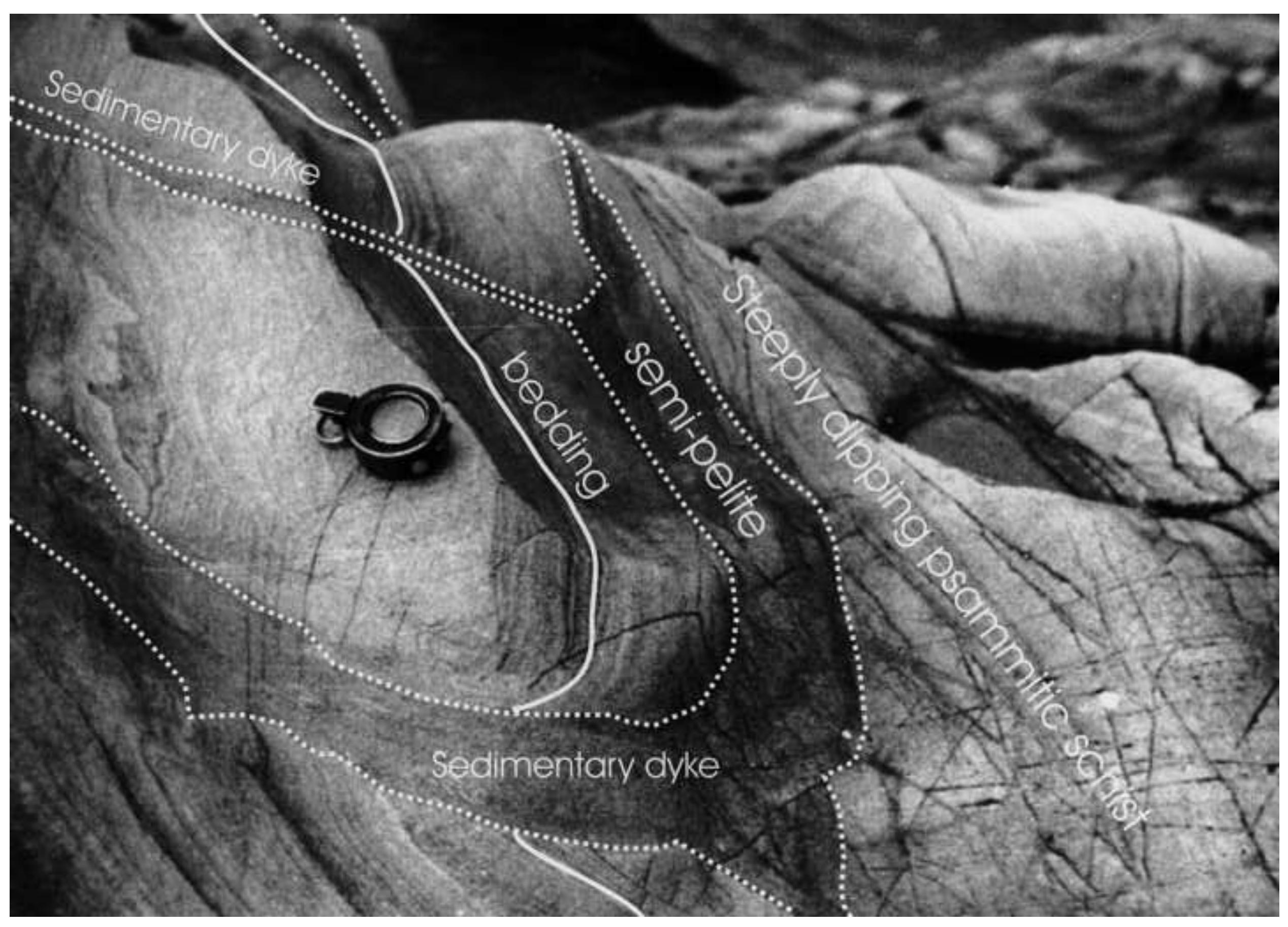


Click here to download high resolution image

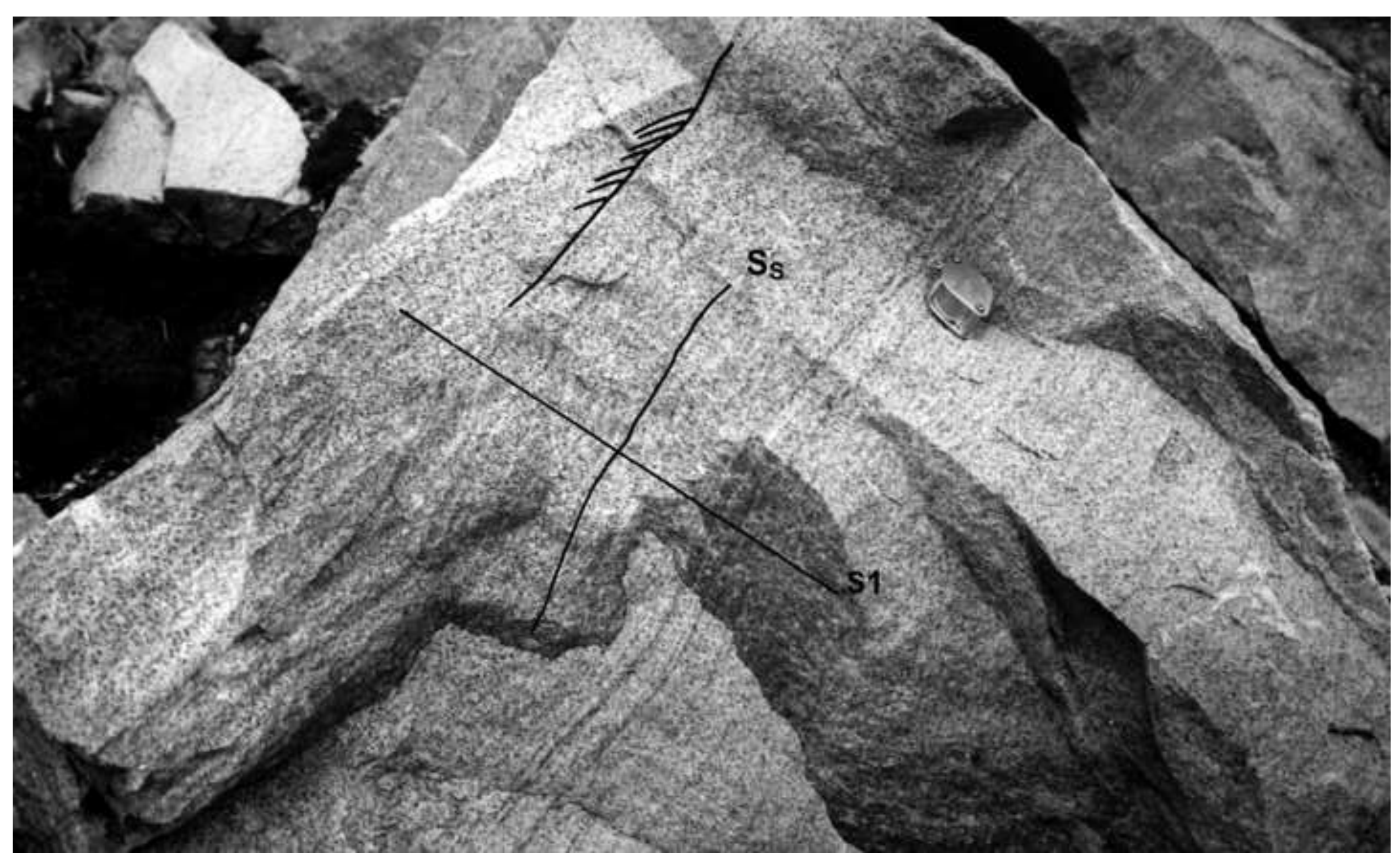




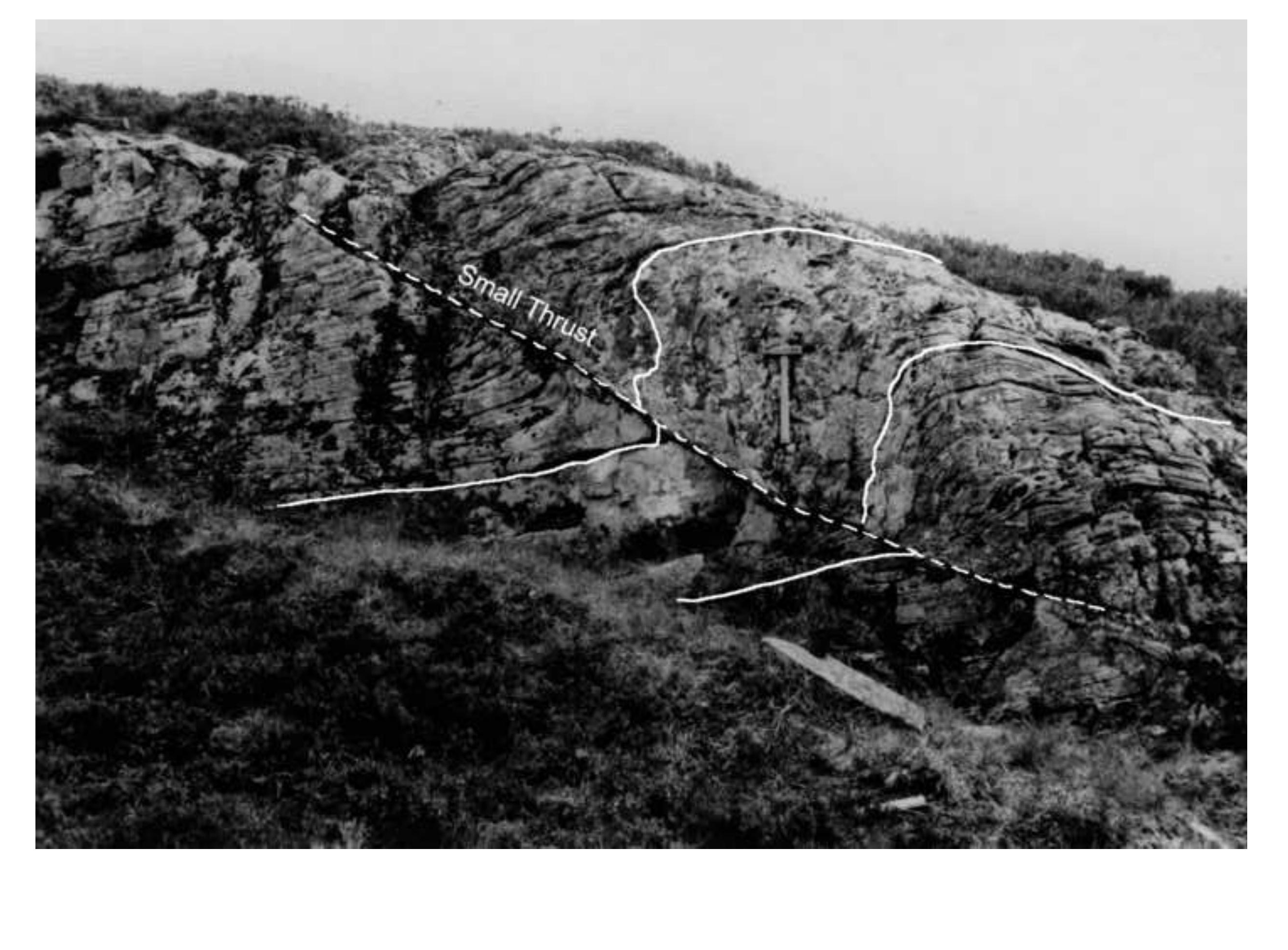

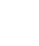

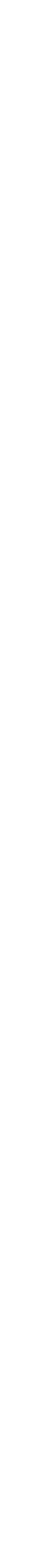


Click here to download high resolution image

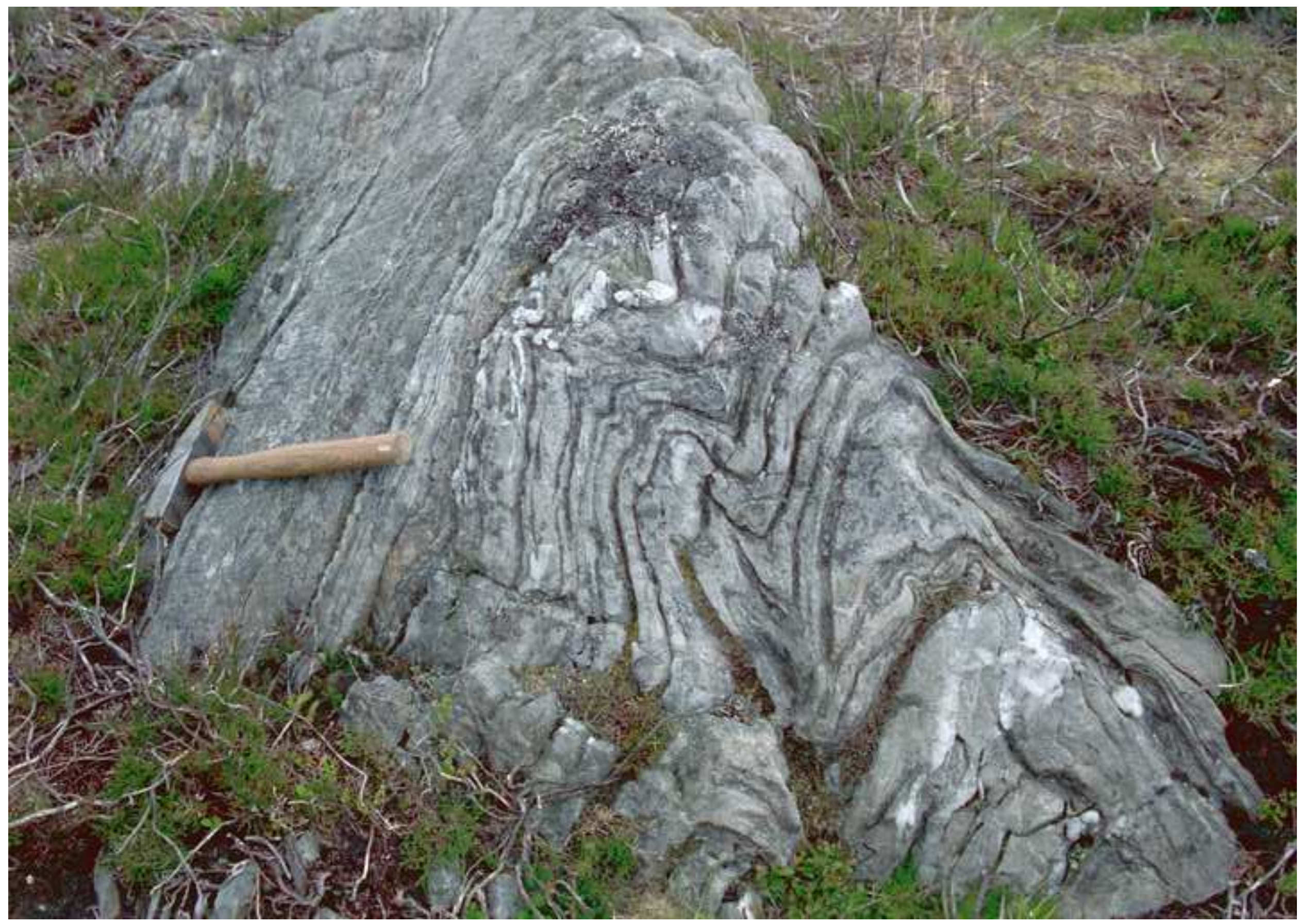


Figure 3.43 colour

Click here to download high resolution image

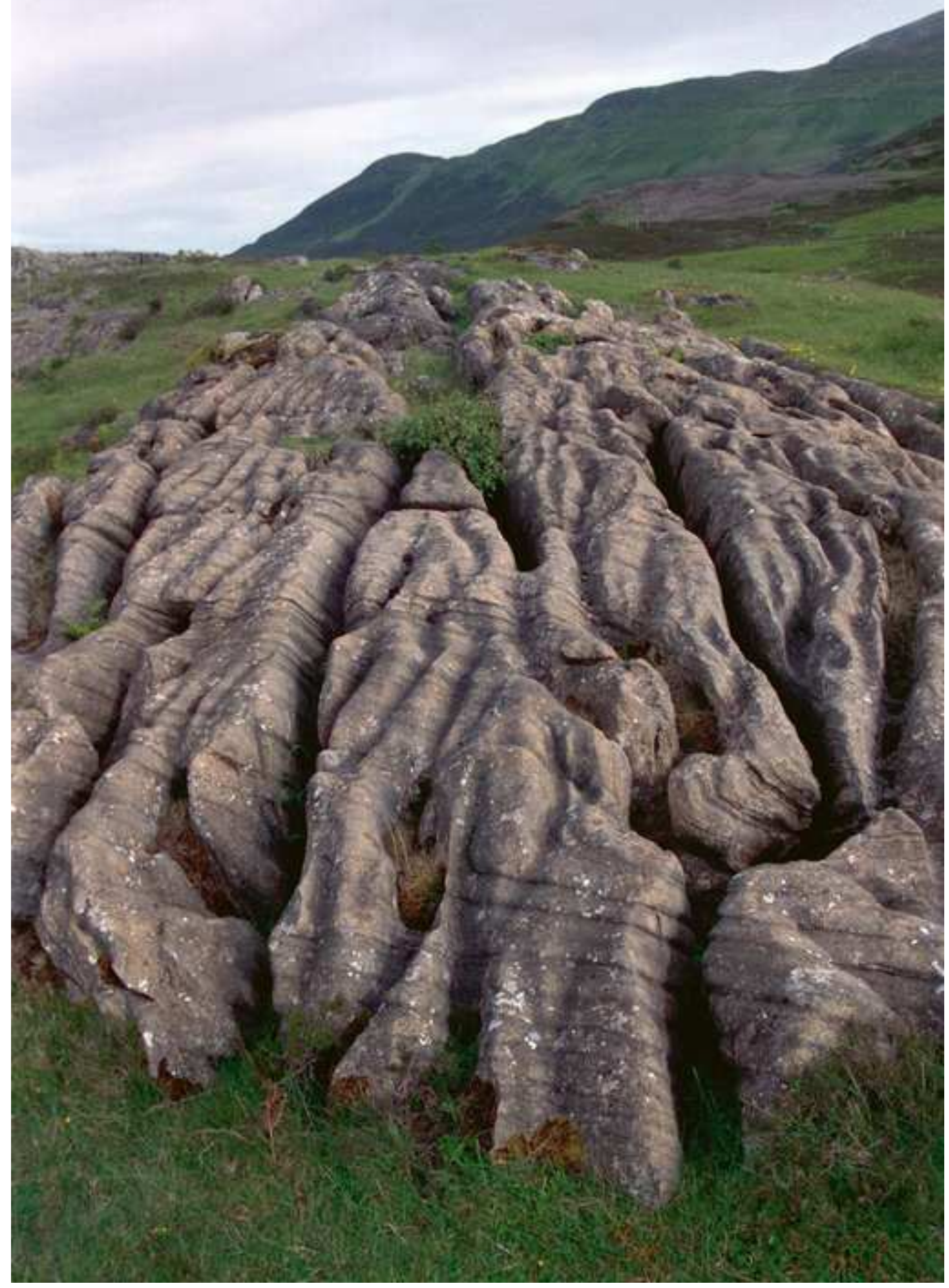


Figure 3.45 colour
Click here to download high resolution image

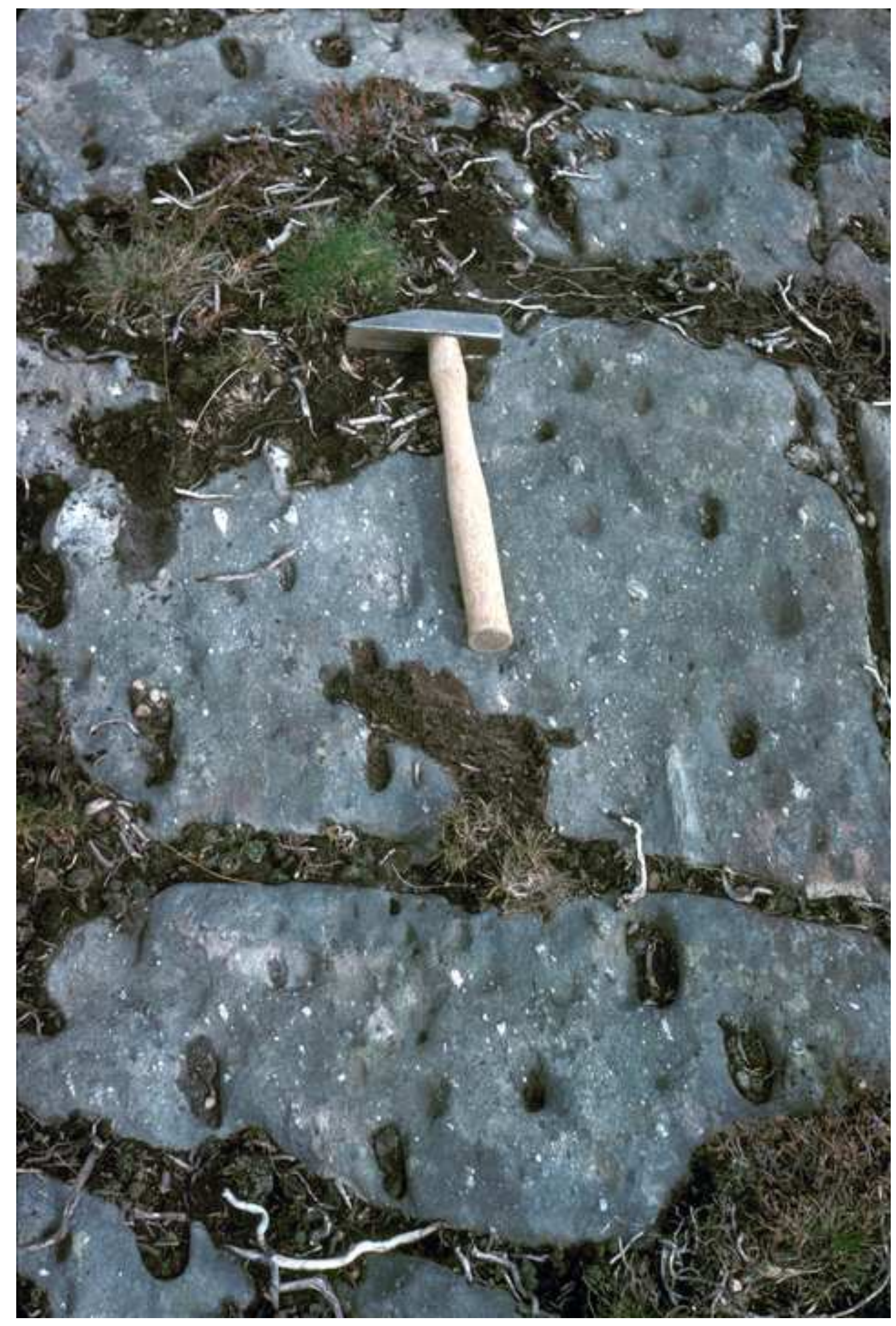


Click here to download high resolution image

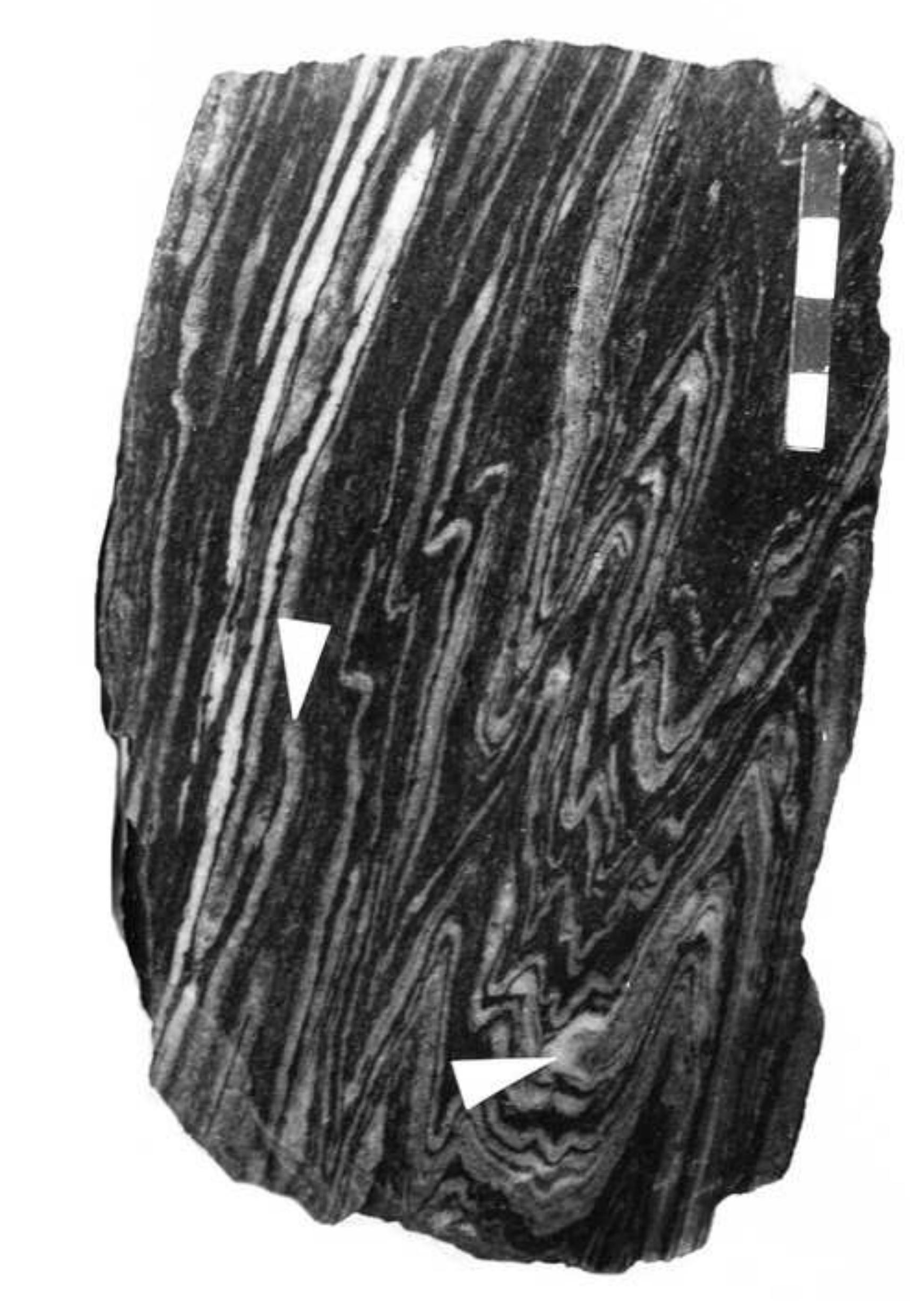

Figure 3.48

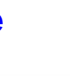
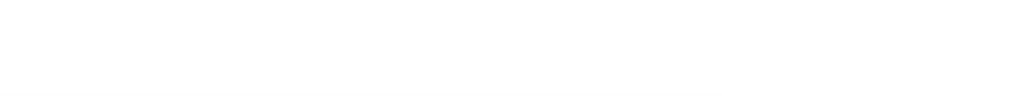
esolution image

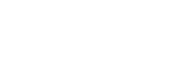




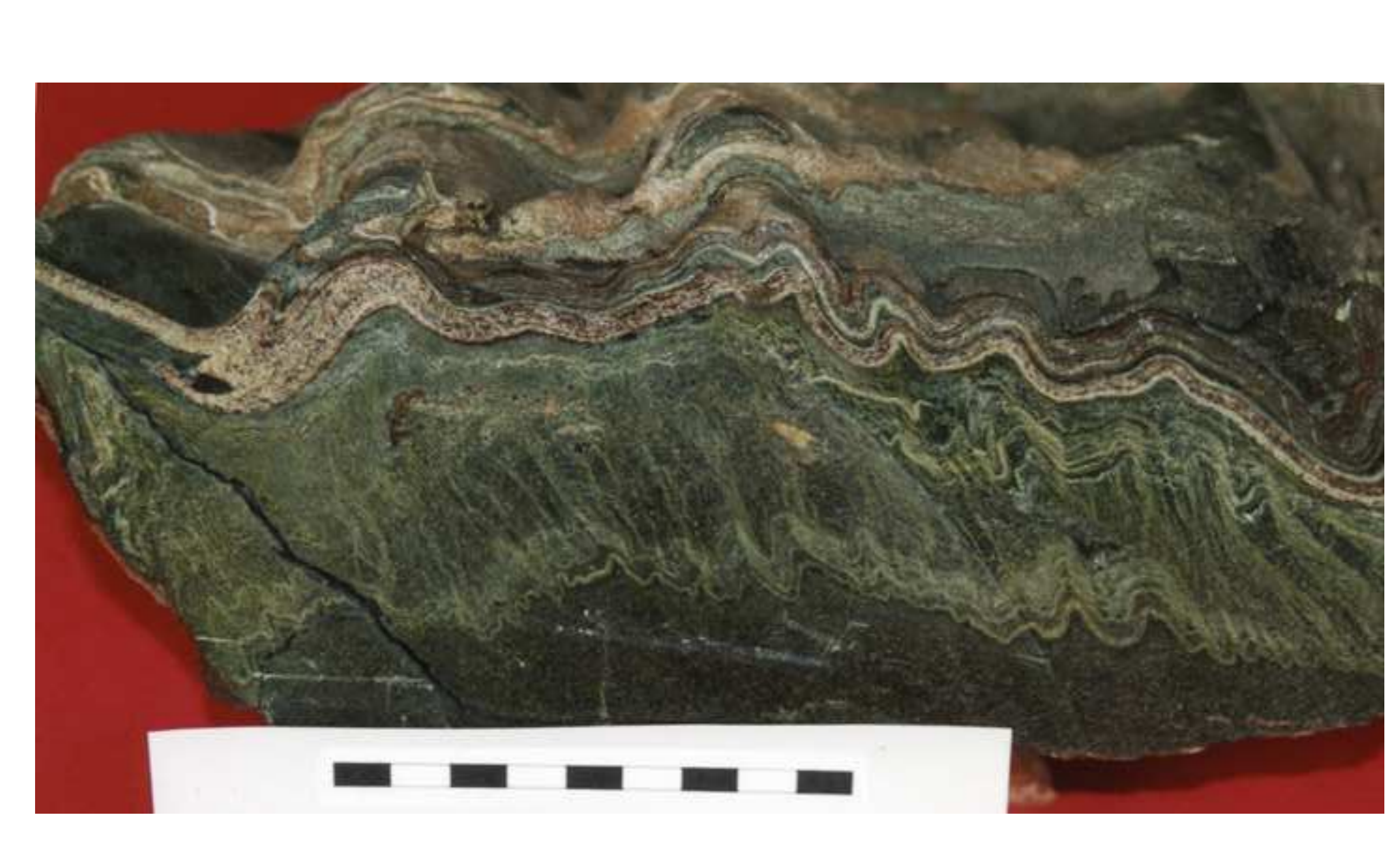

click here to do

列
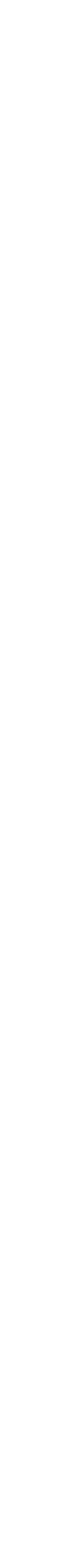

\author{
oad high resolution image
}


Click here to download high resolution image
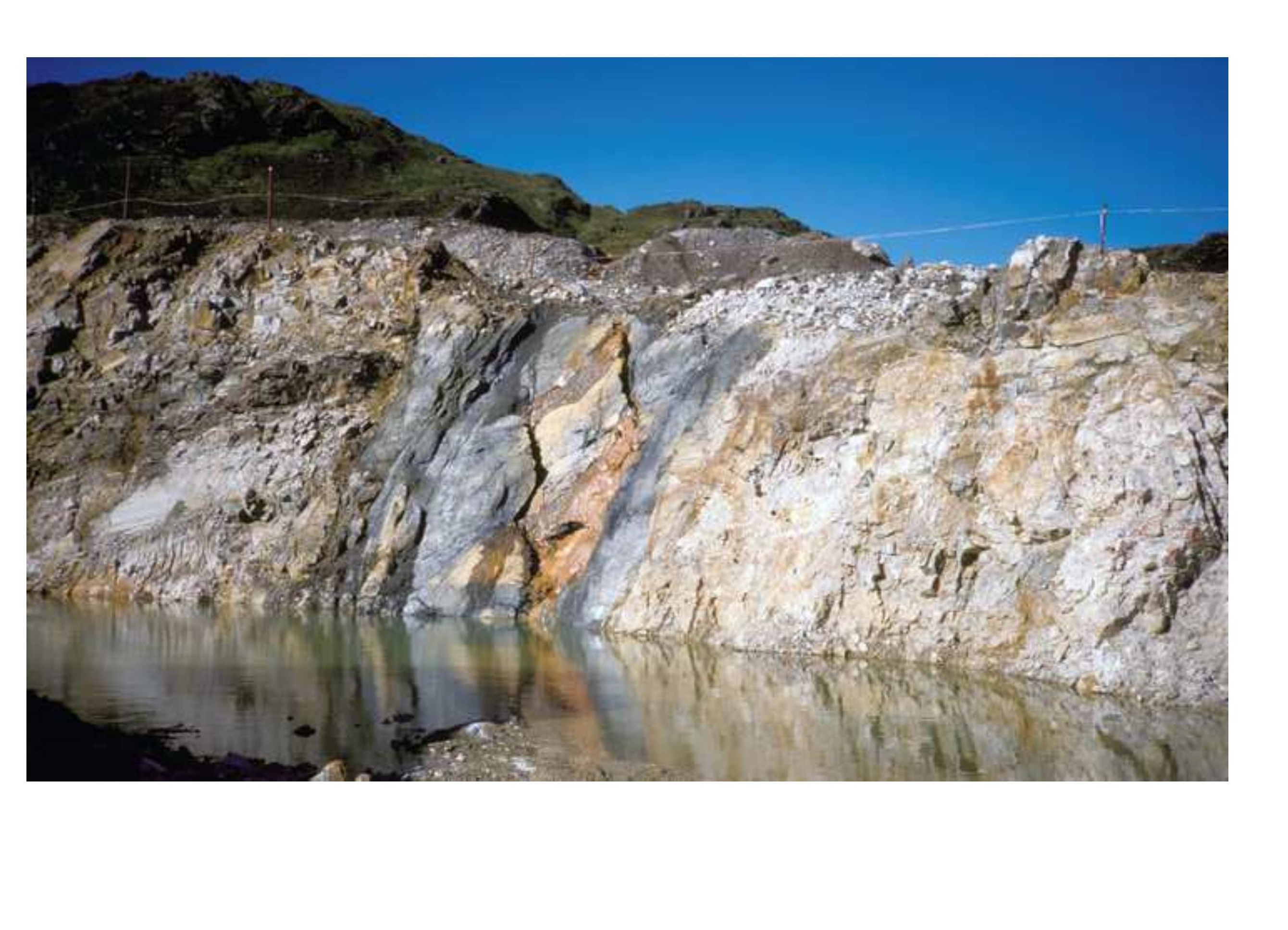


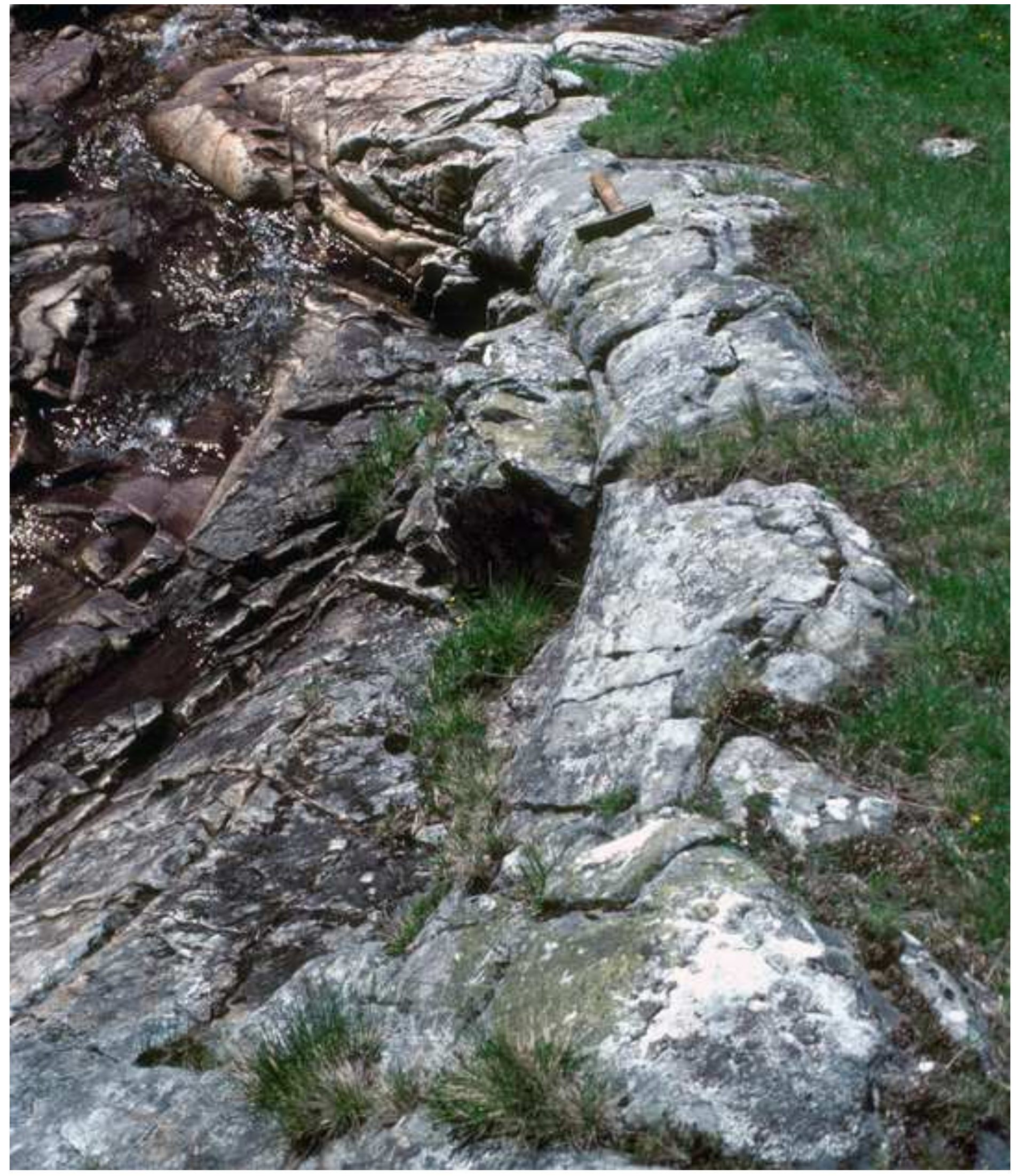




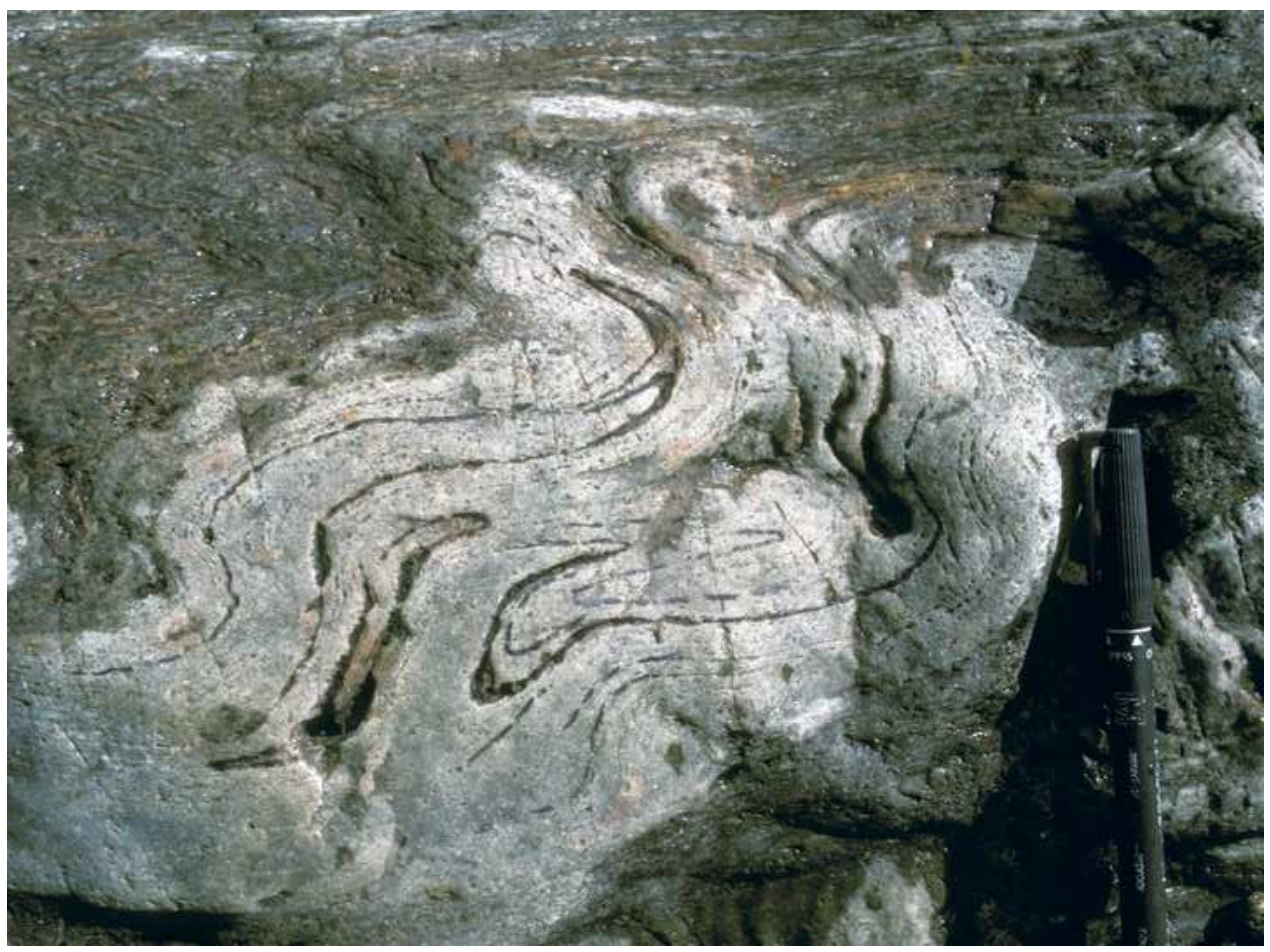

\section{Click here to download high resolution image}


Figure 3.58 colour
Click here to download high resolution image

Figure 3.58 colour
Click here to download high resolution image

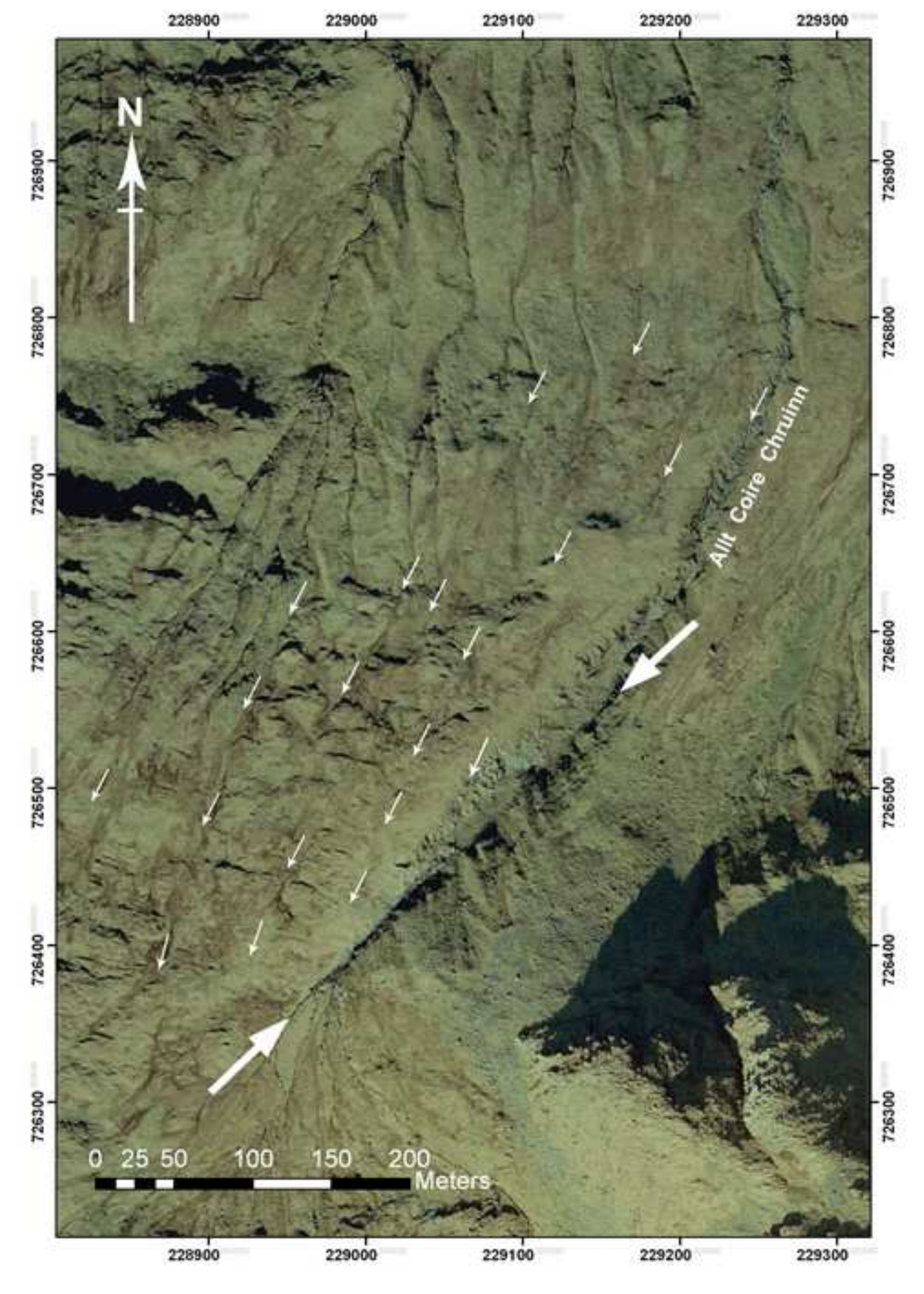

政

?




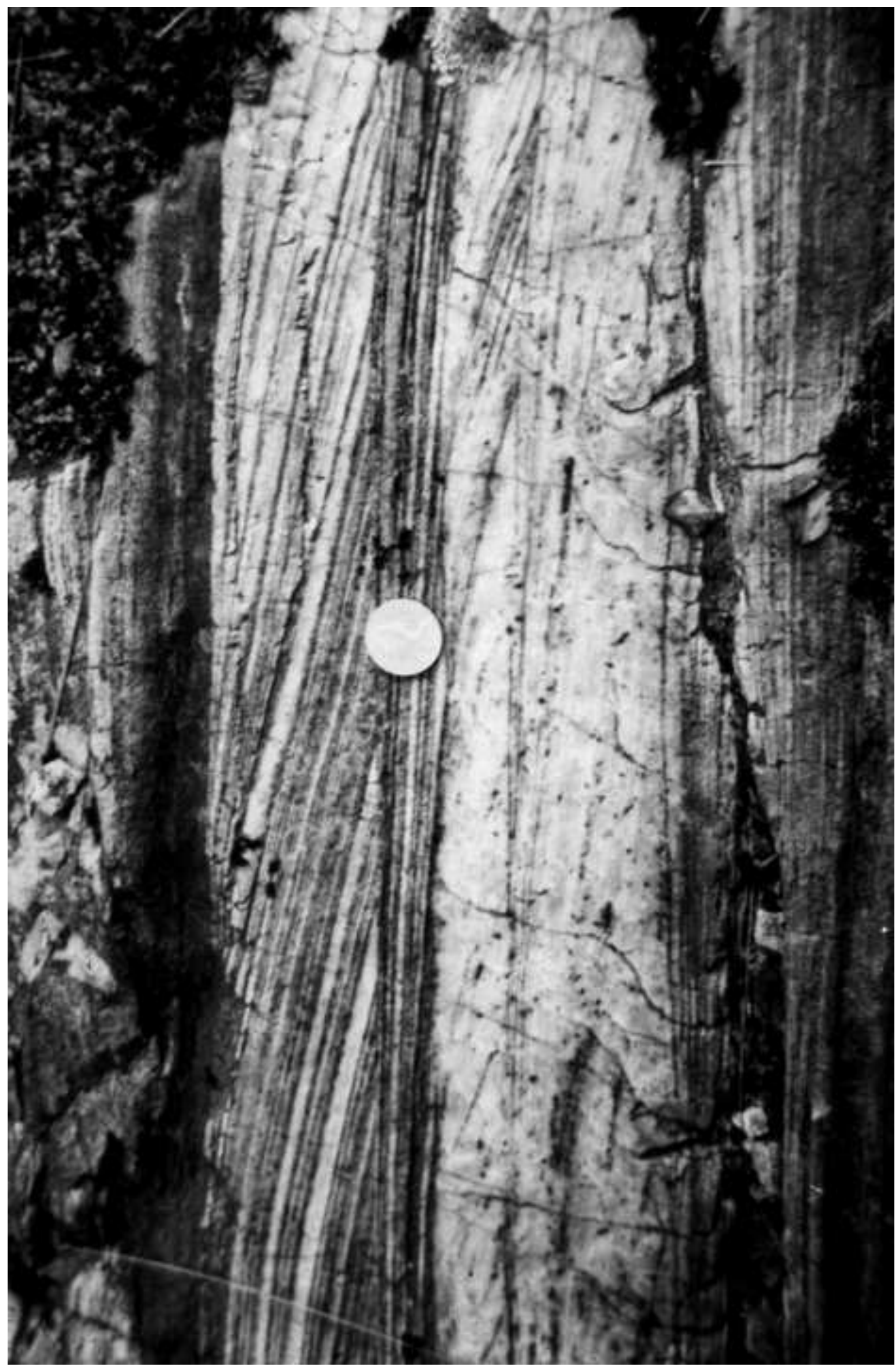




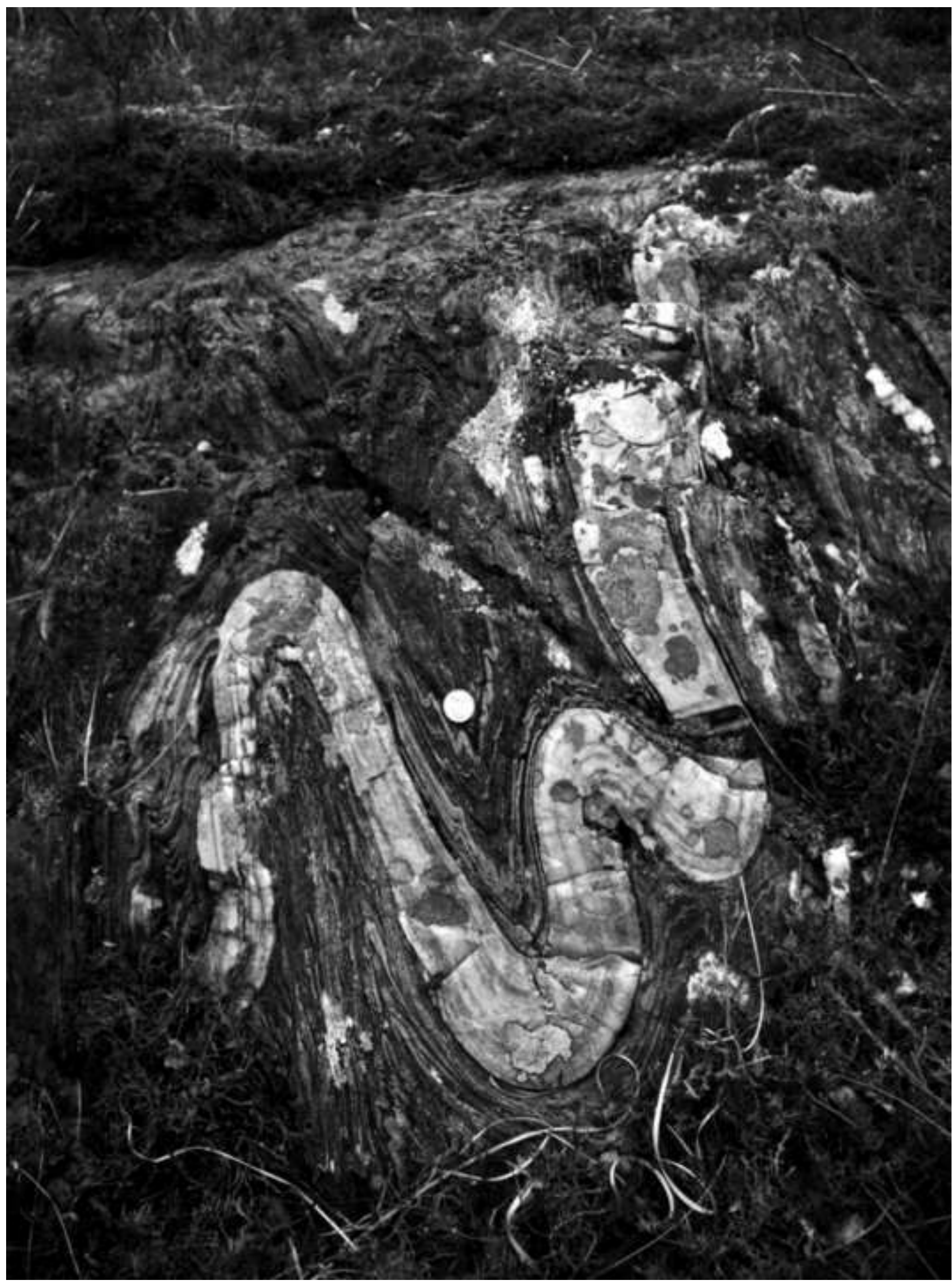




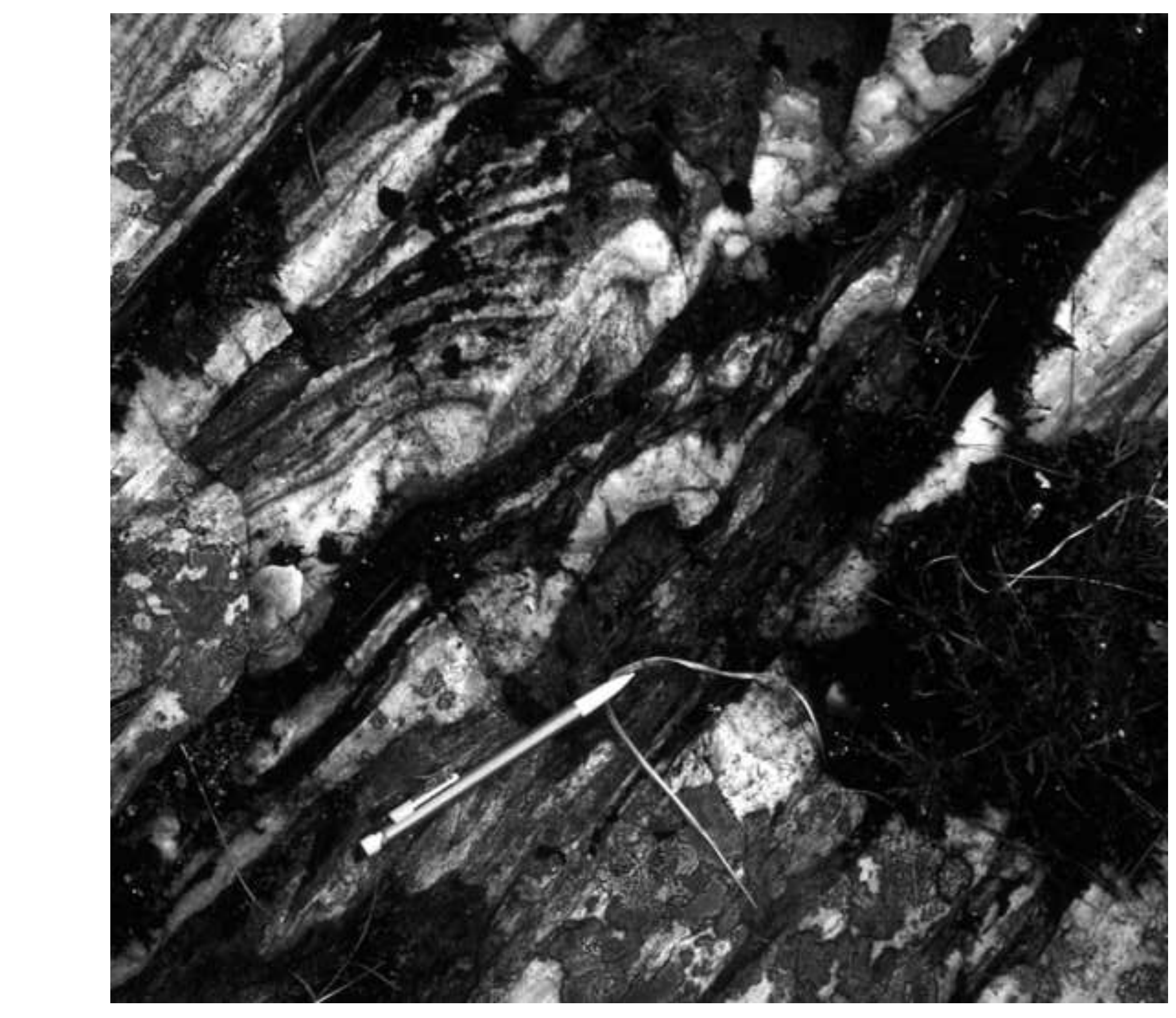

\section{Click here to download high resolution image


Click here to download high resolution image

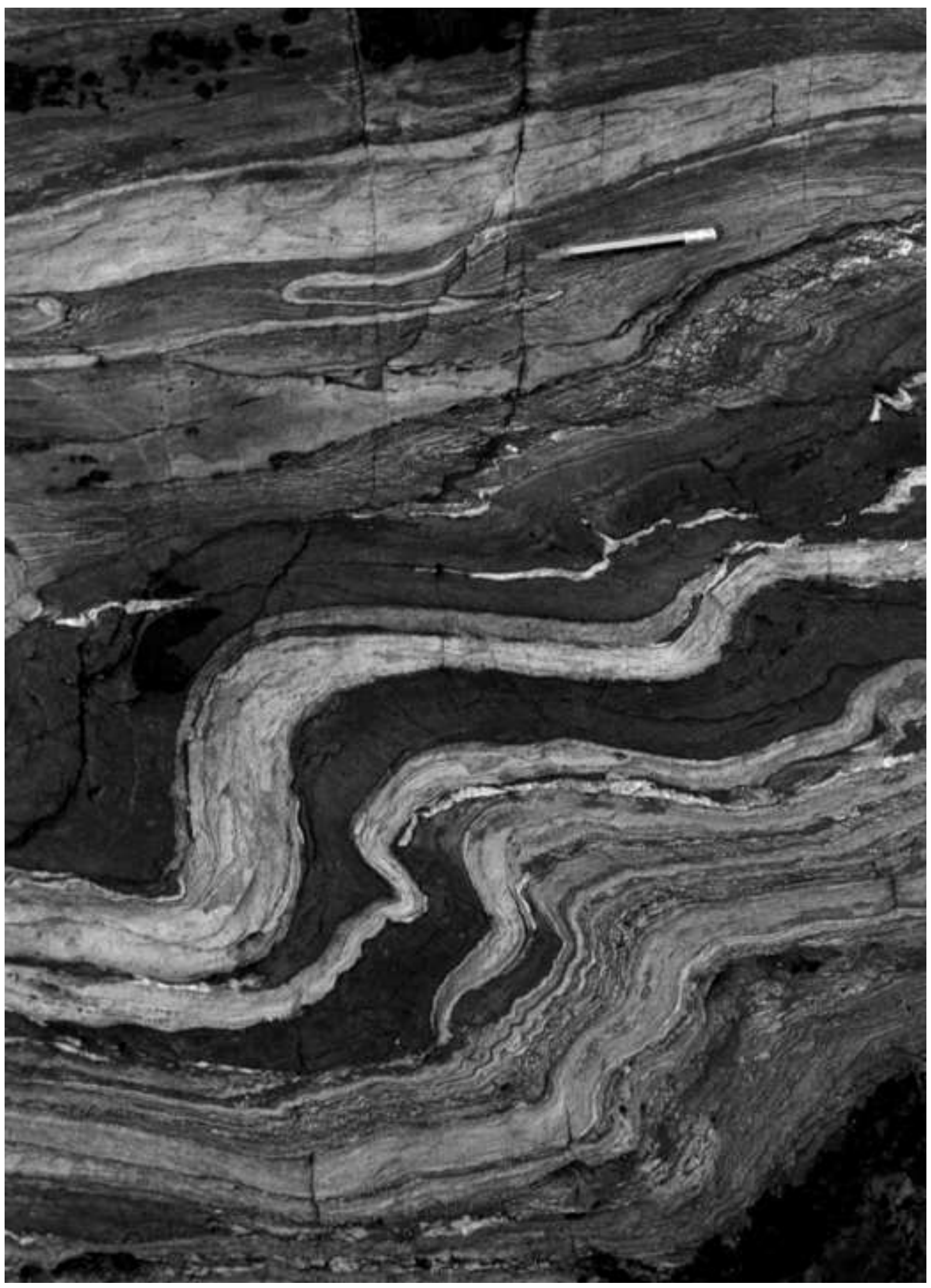




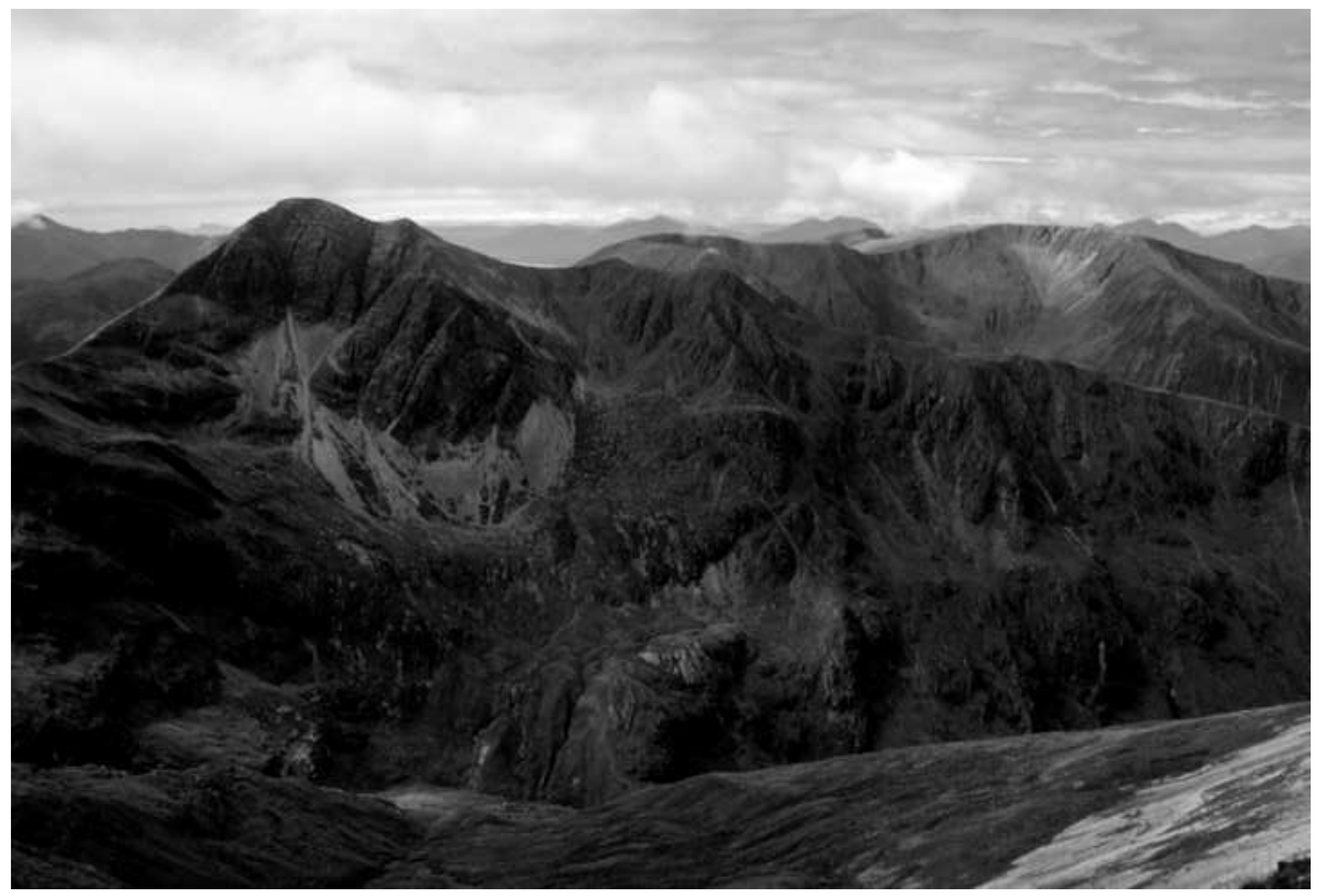


Figure $3.16 \mathrm{~B} \& \mathrm{~W}$
Click here to download high resolution image

Figure $3.16 \mathrm{~B} \& W$
Click here to download high resolution image

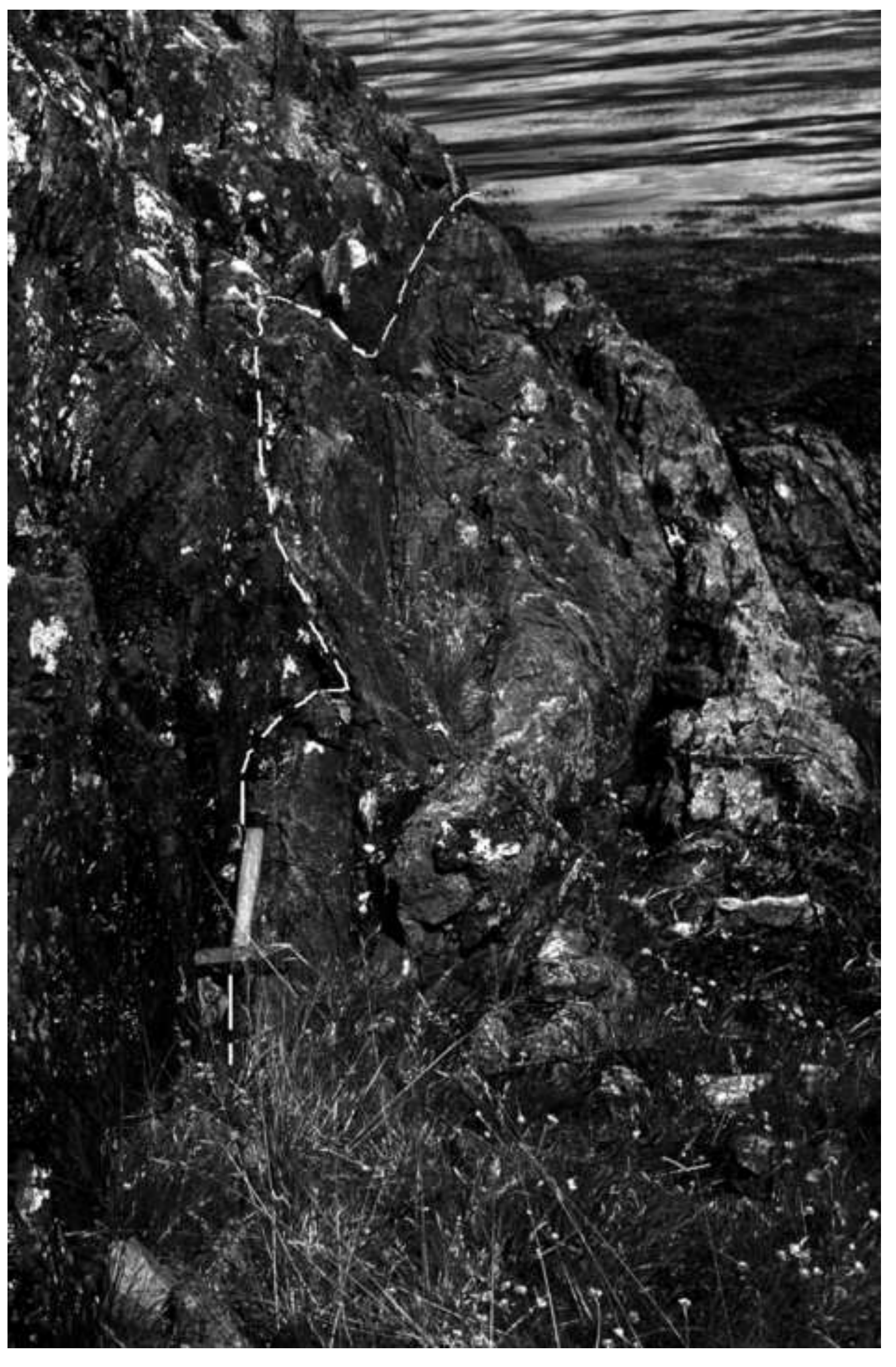


Figure $3.19 a \mathrm{~B} \& W$
Click here to download high resolution image

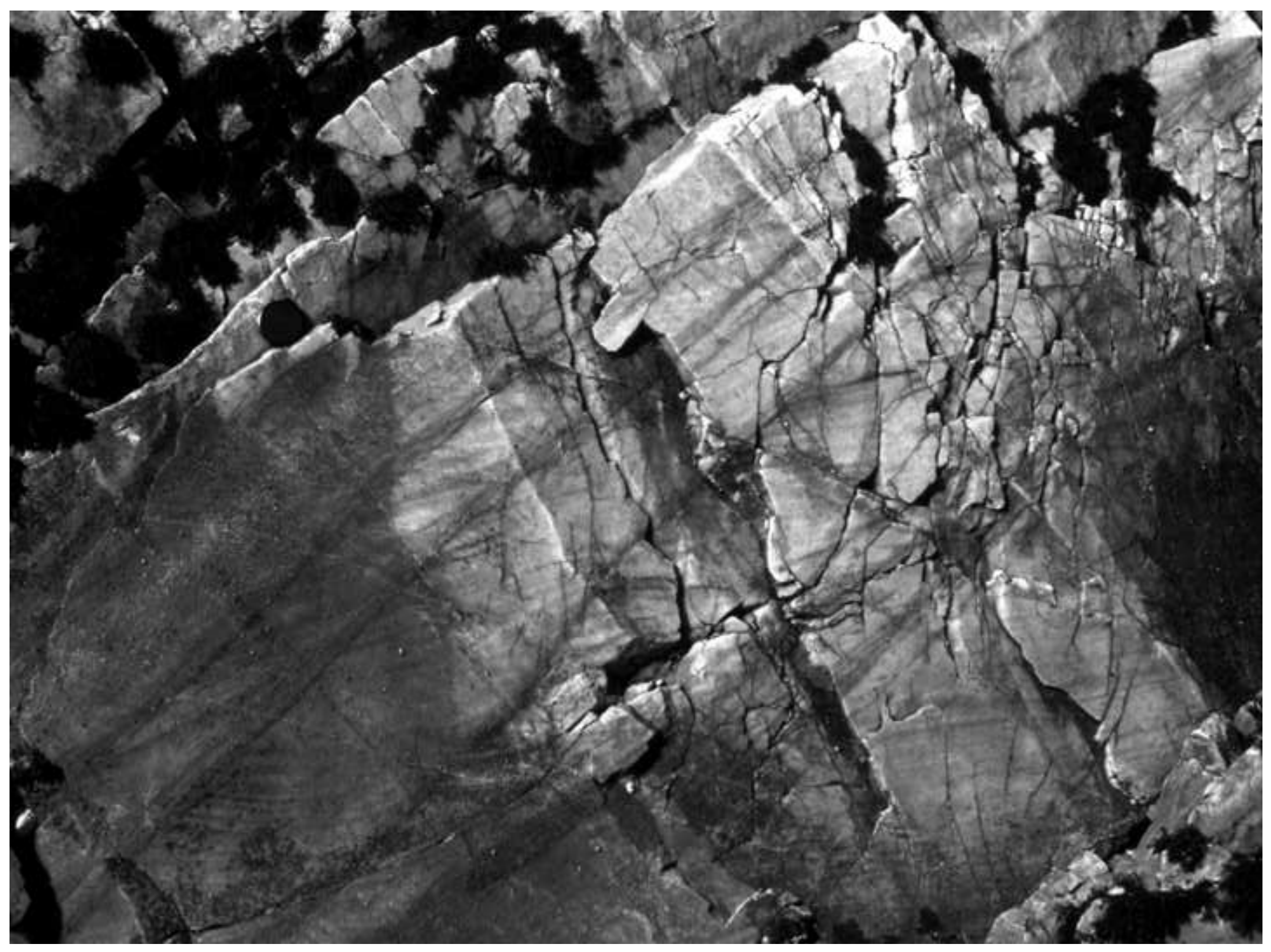


Click here to download high resolution image

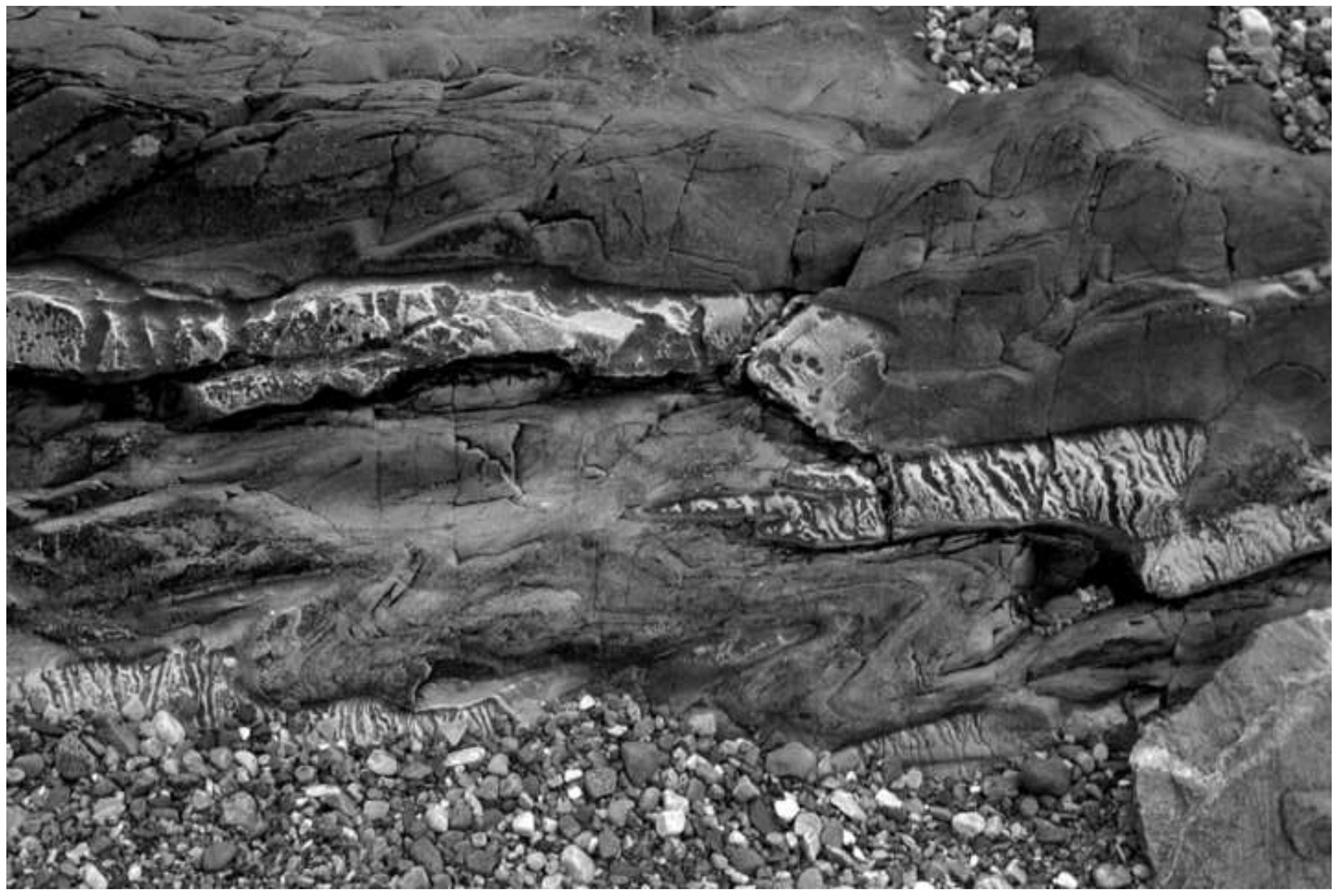


Figure 3.21a B\&W

Click here to download high resolution image

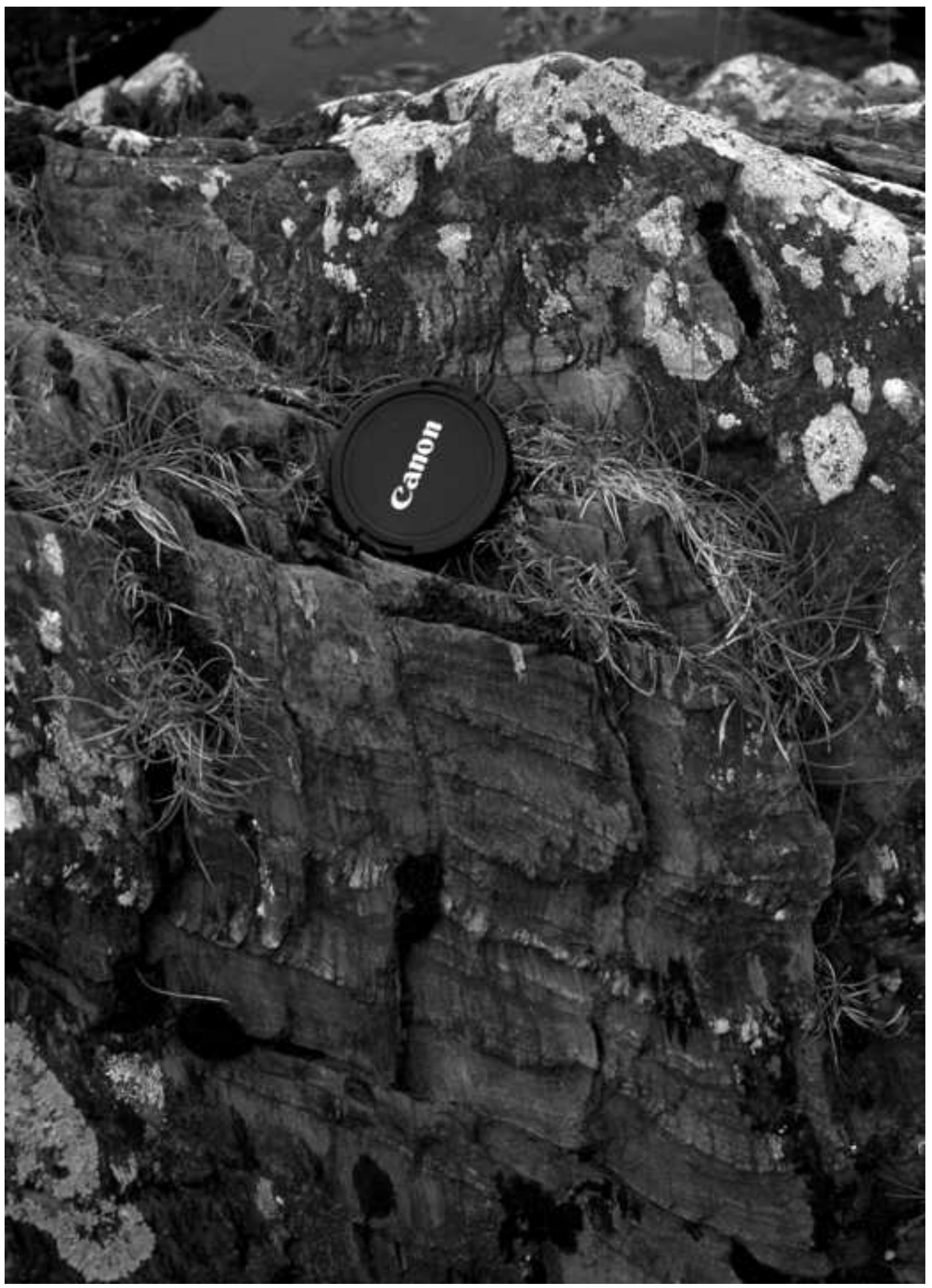




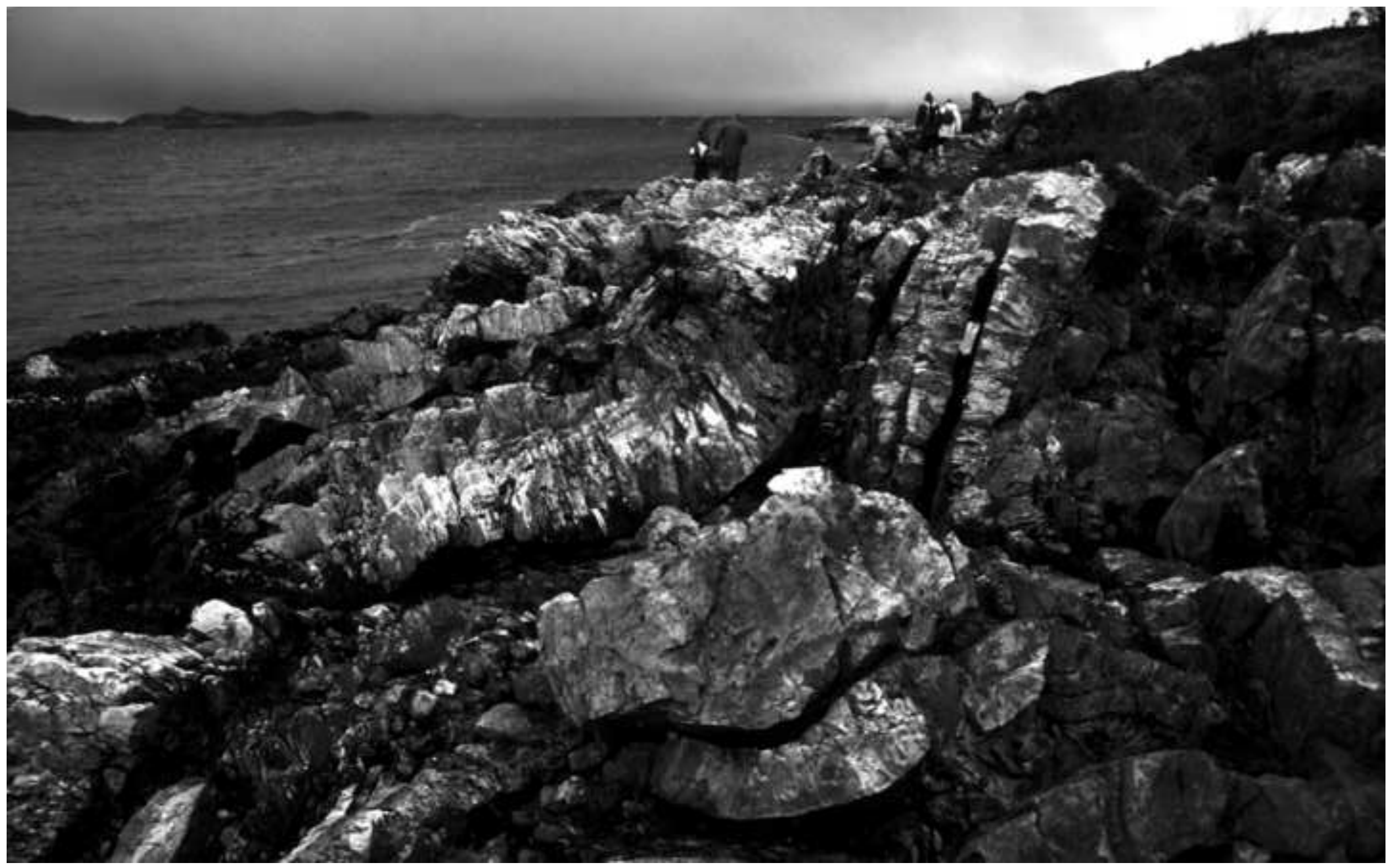




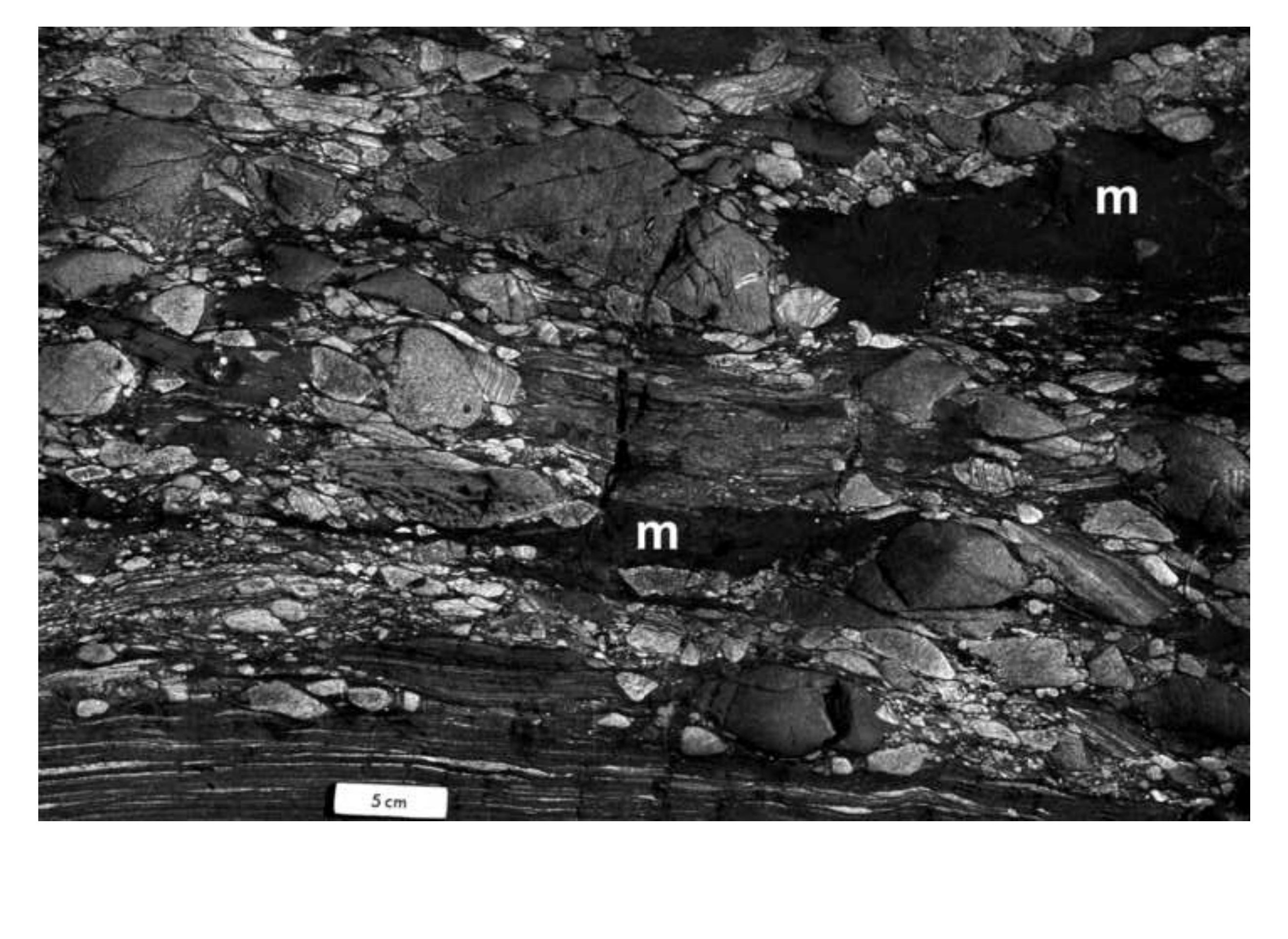




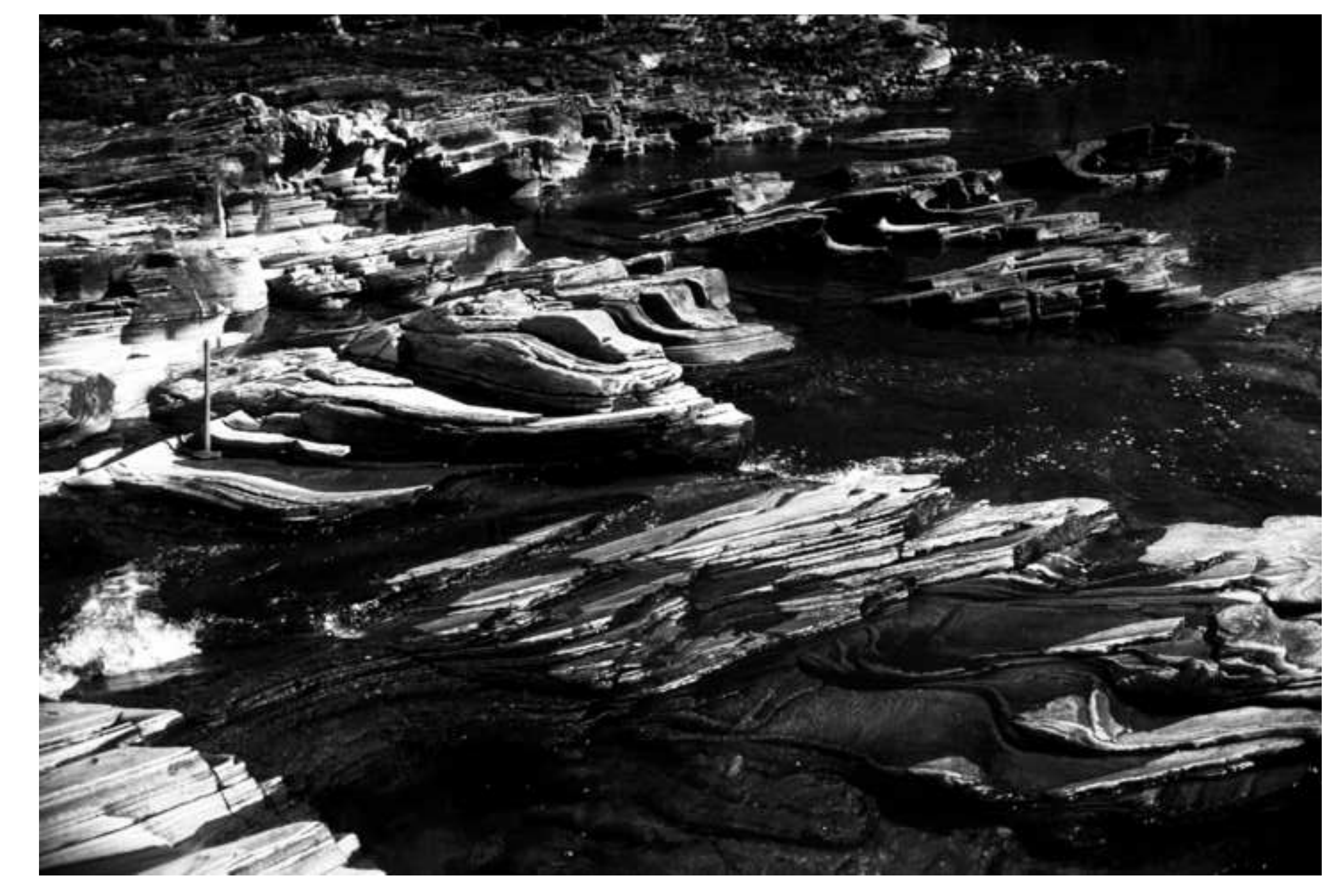



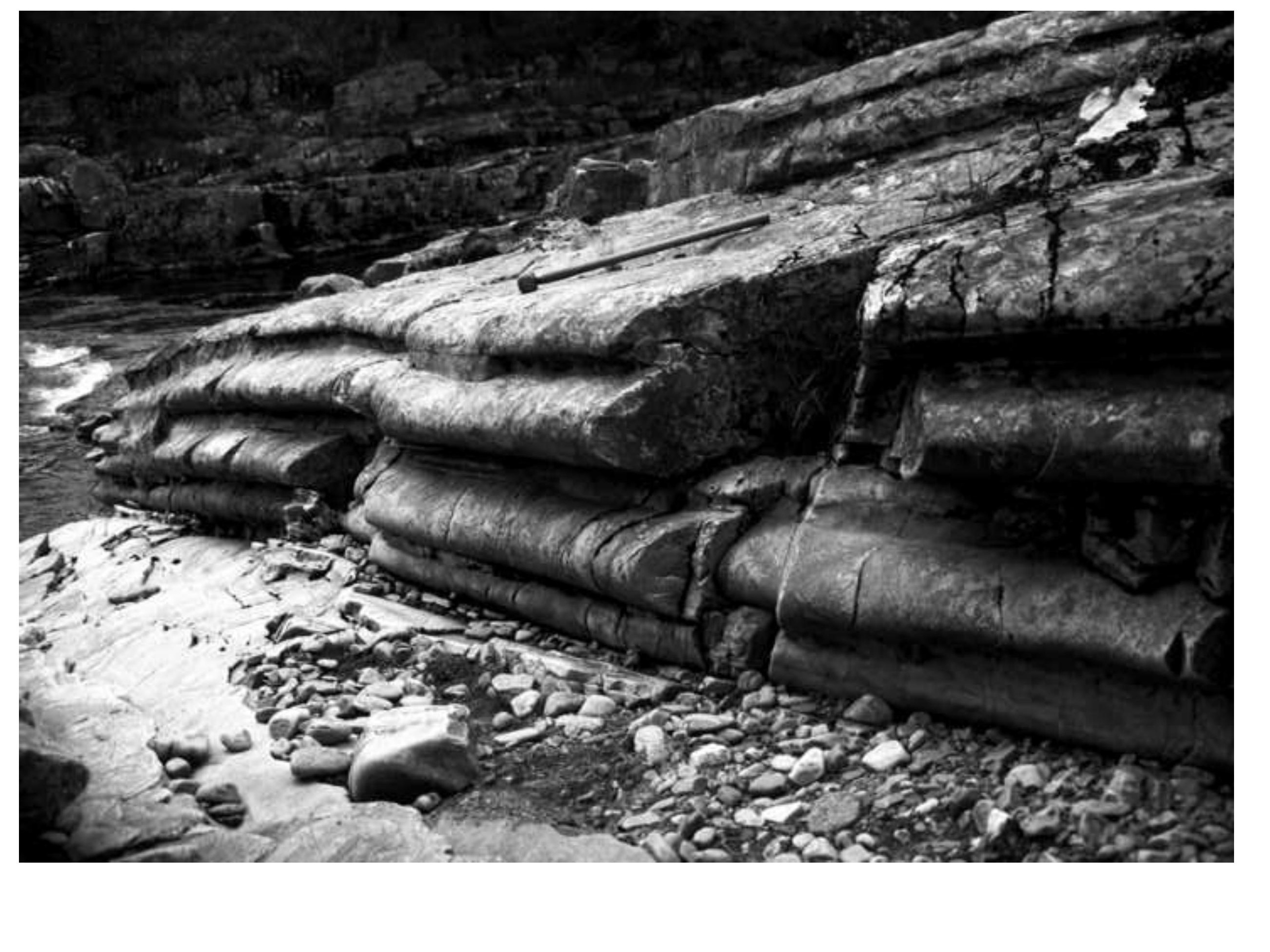


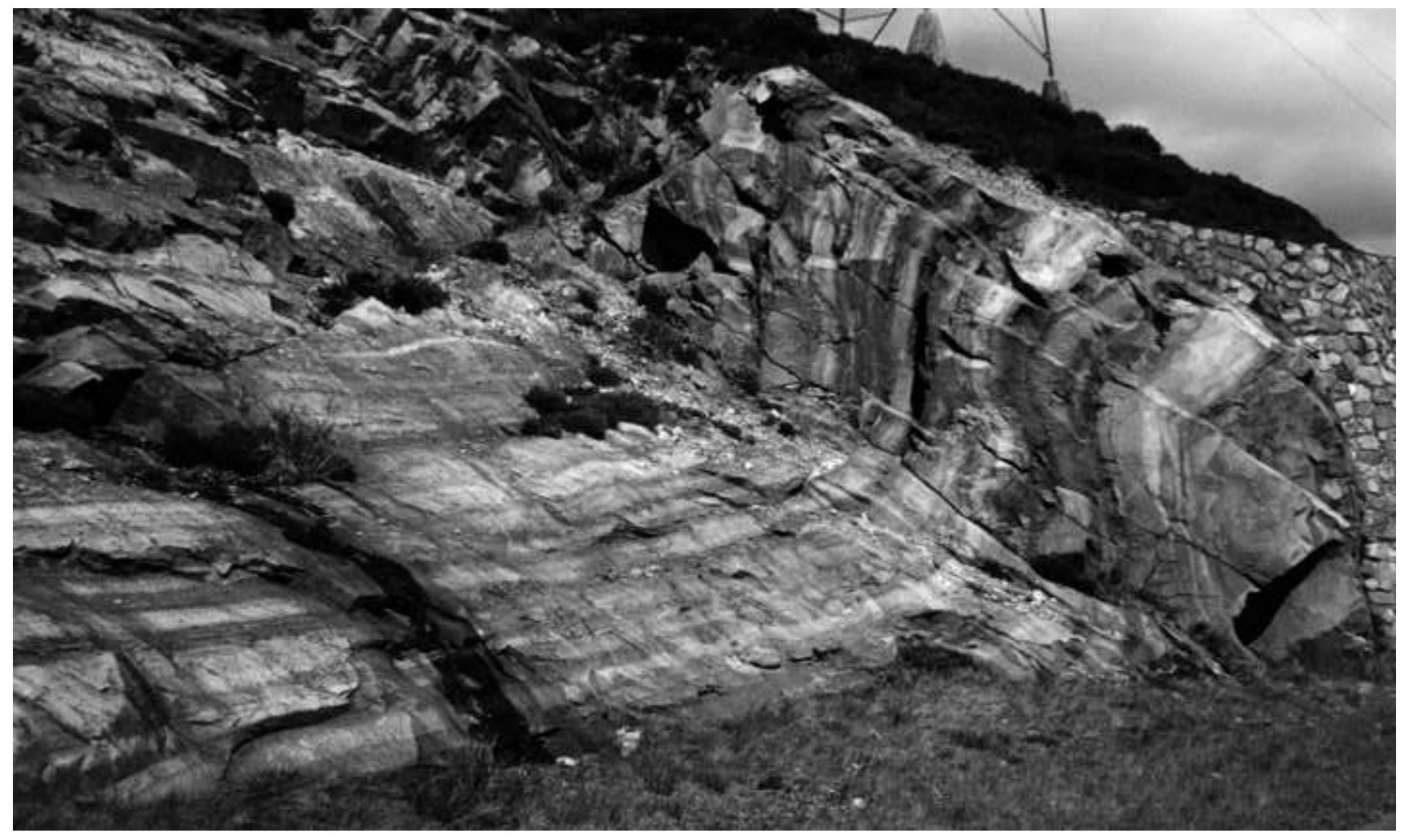




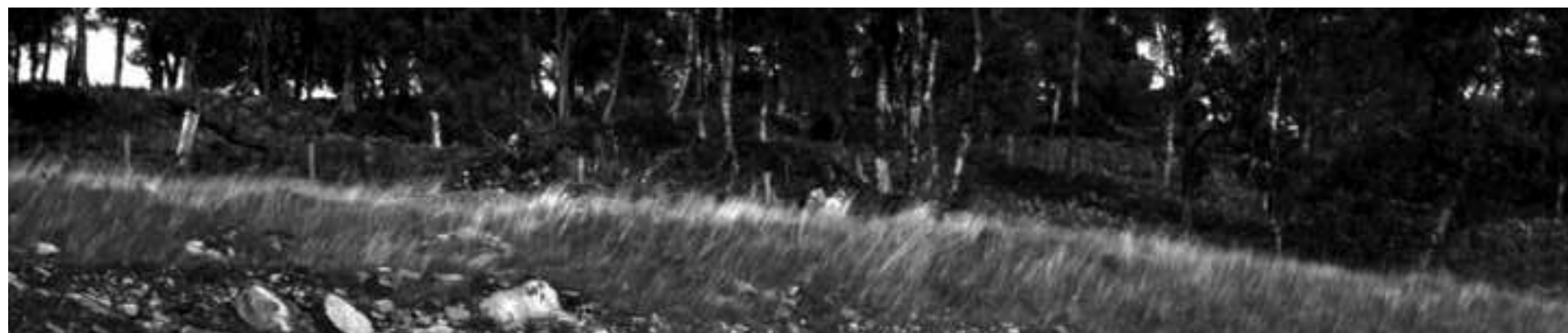

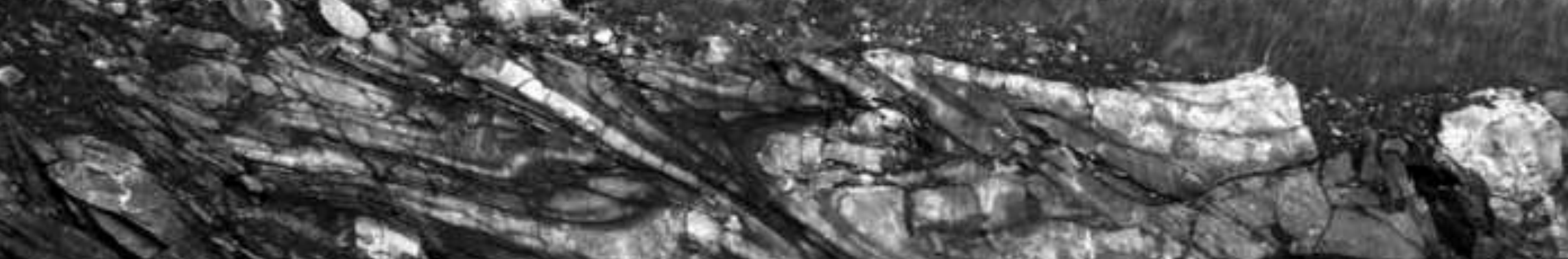

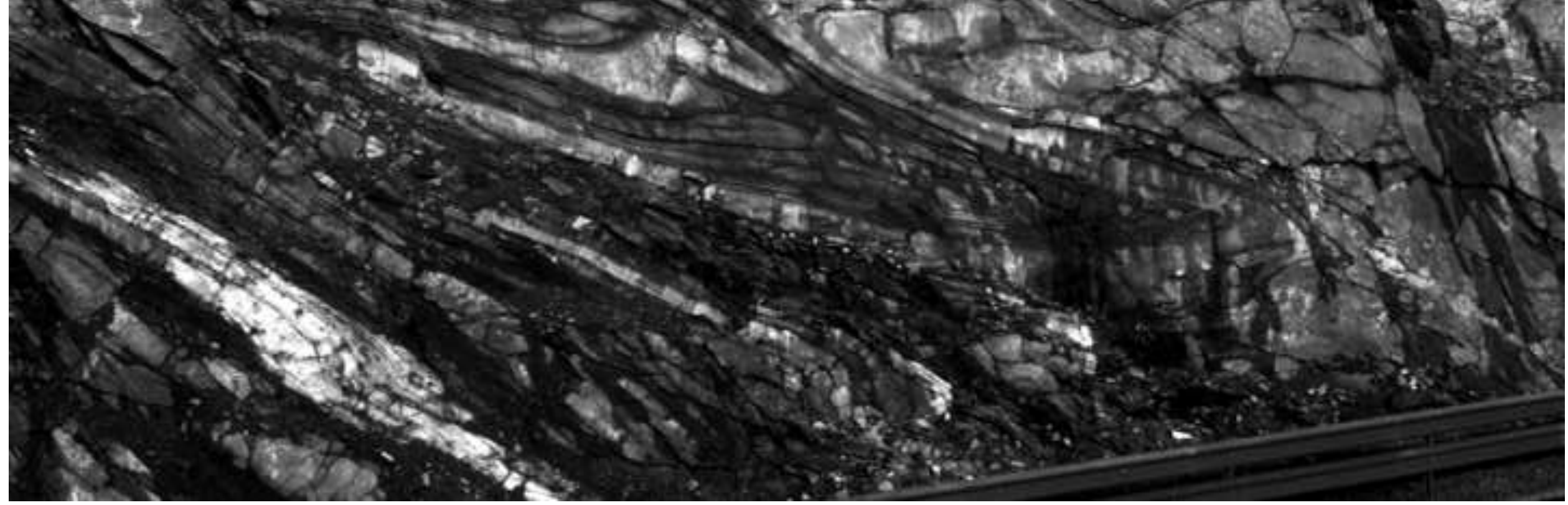


Click here to download high resolution image

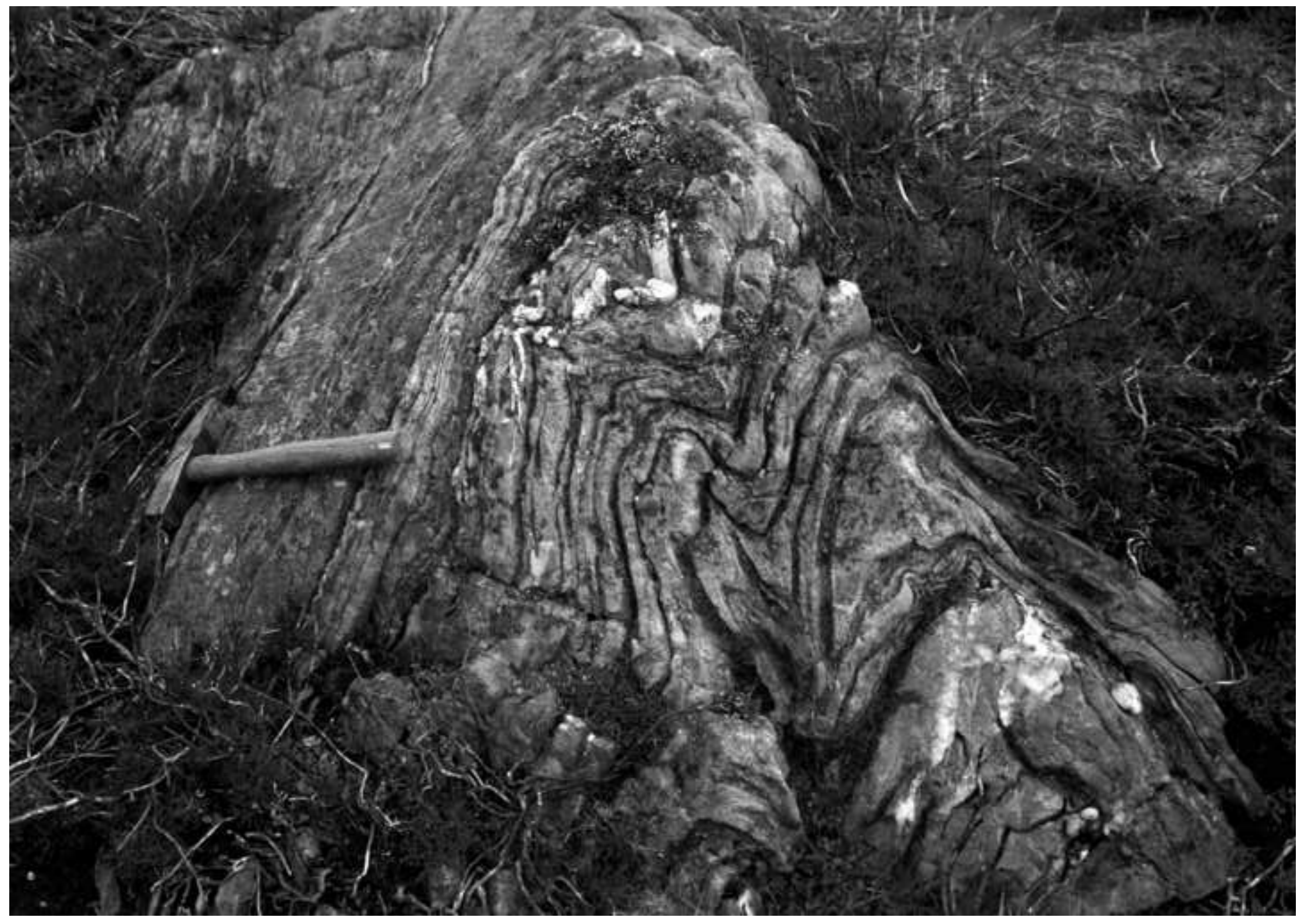




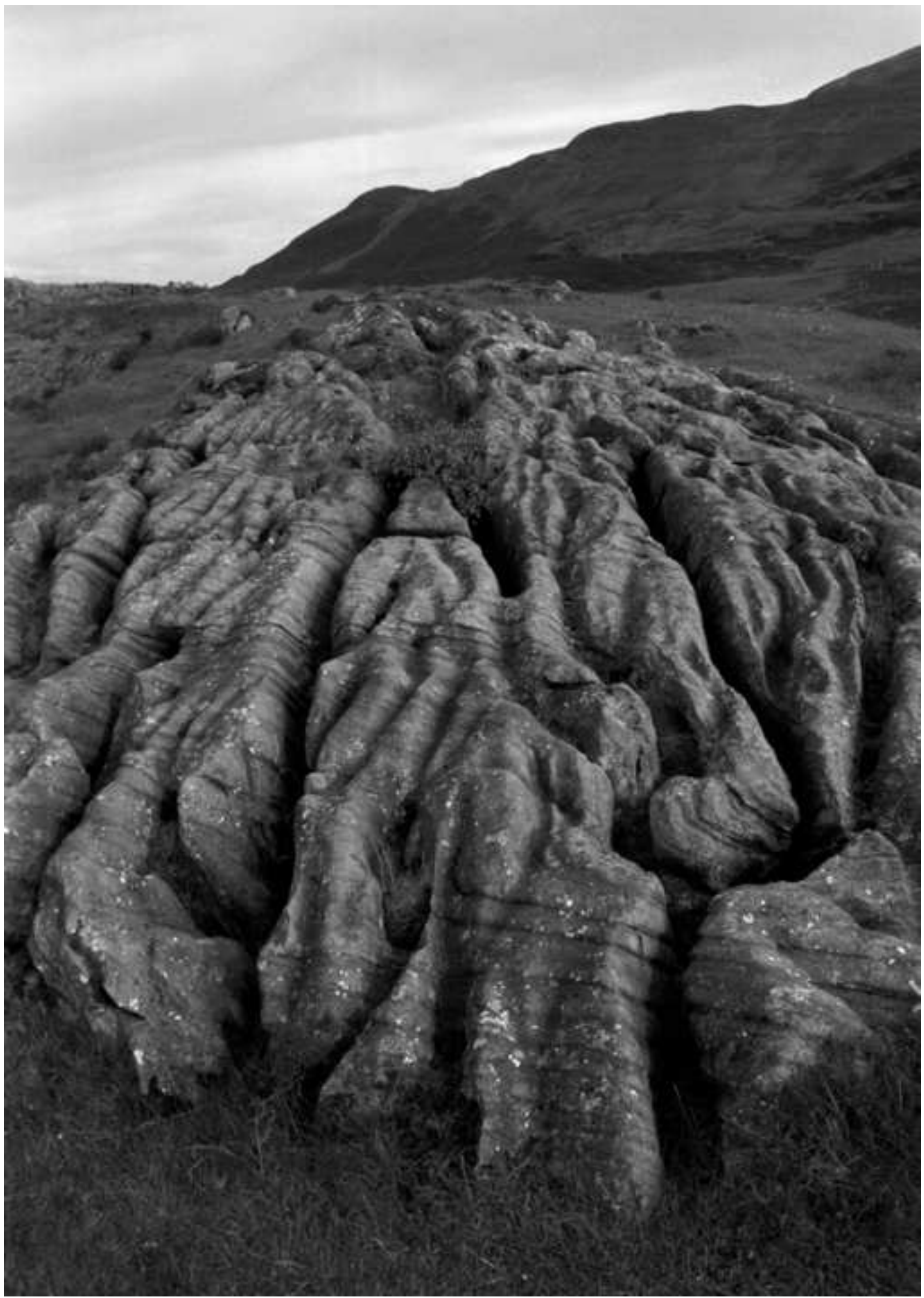




\section{Click here to download high resolution image}

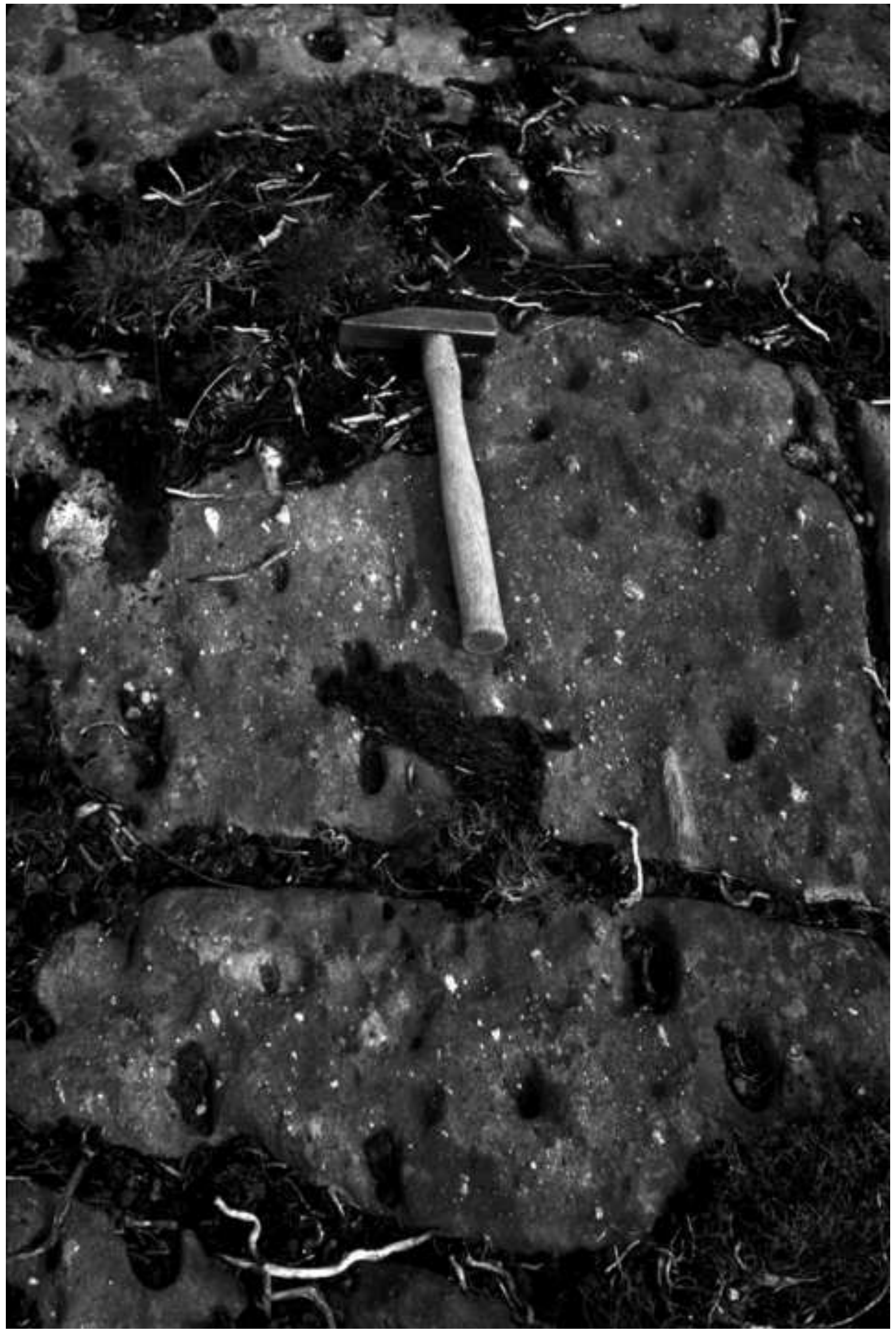




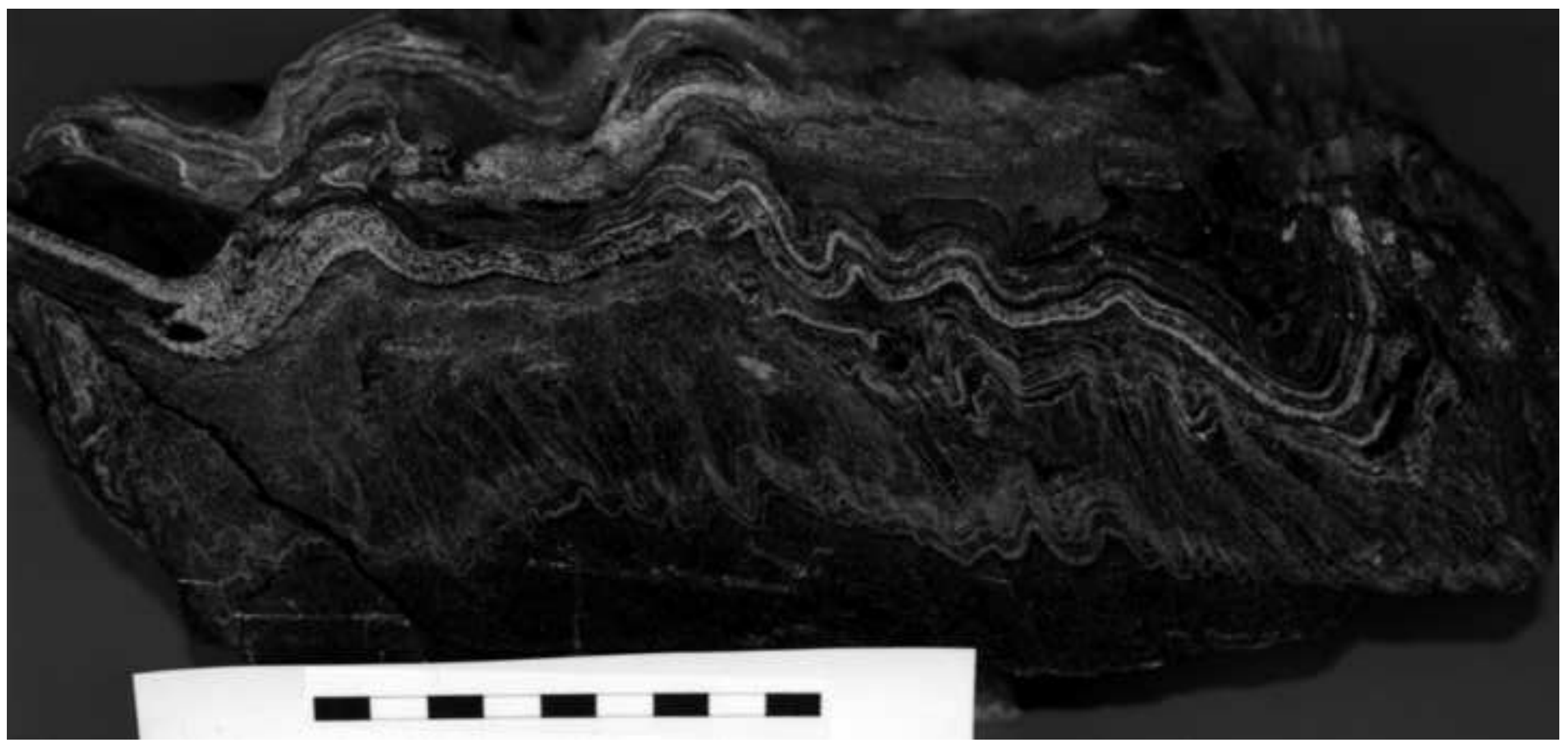


Click here to download high resolution image

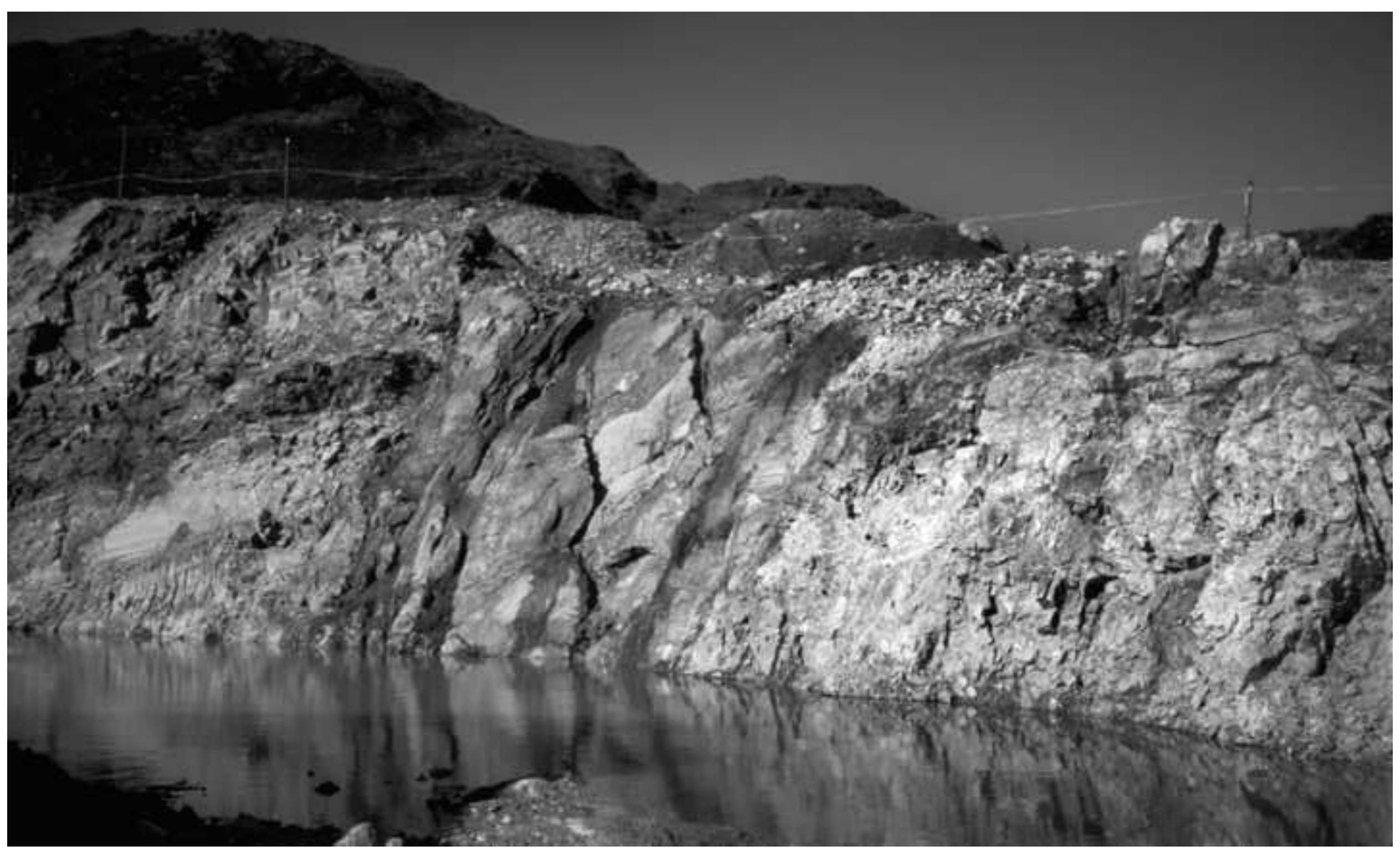




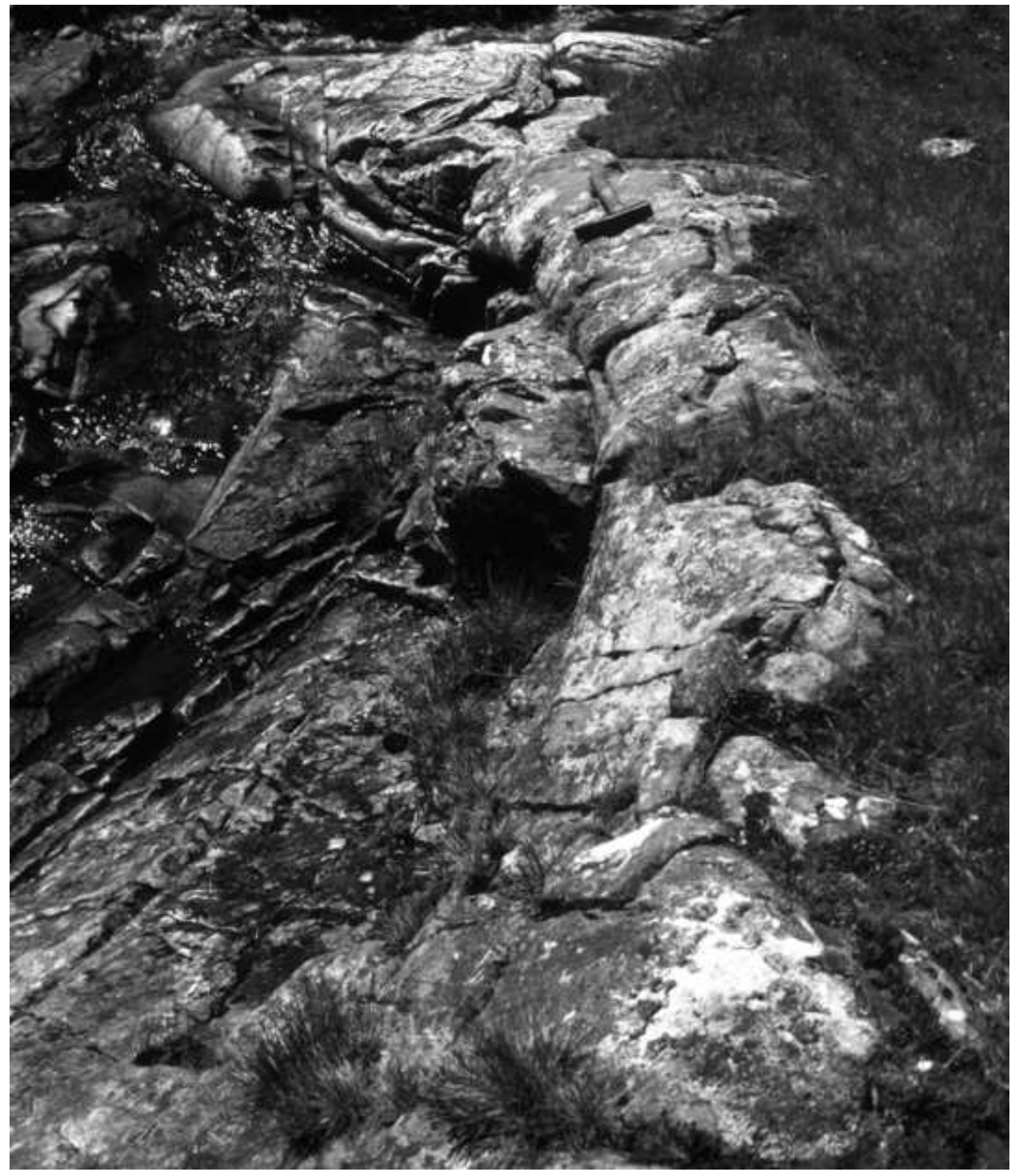




\section{$3.56 \mathrm{~B} \& \mathrm{~W}$}

Click here to download high resolution image

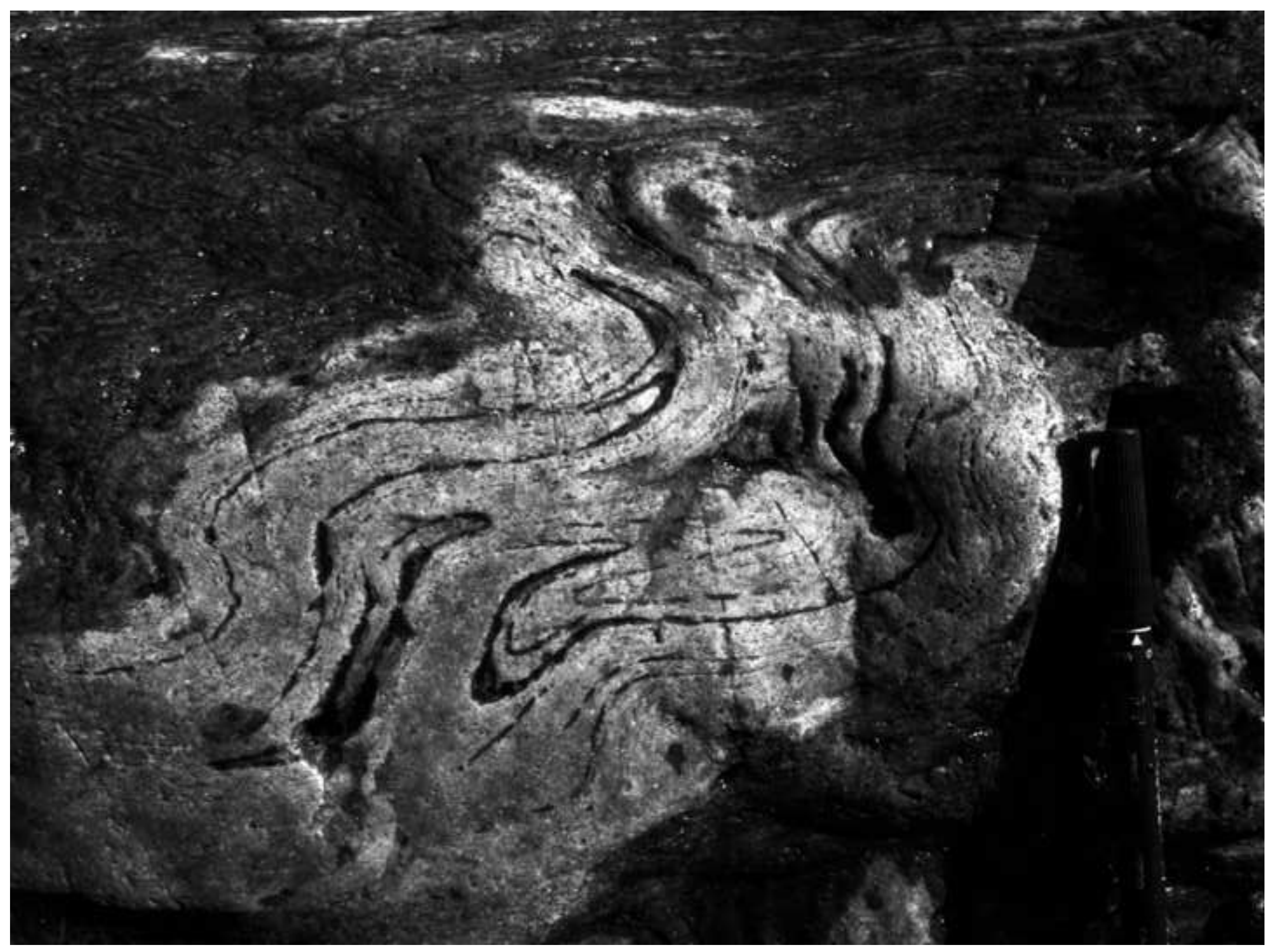




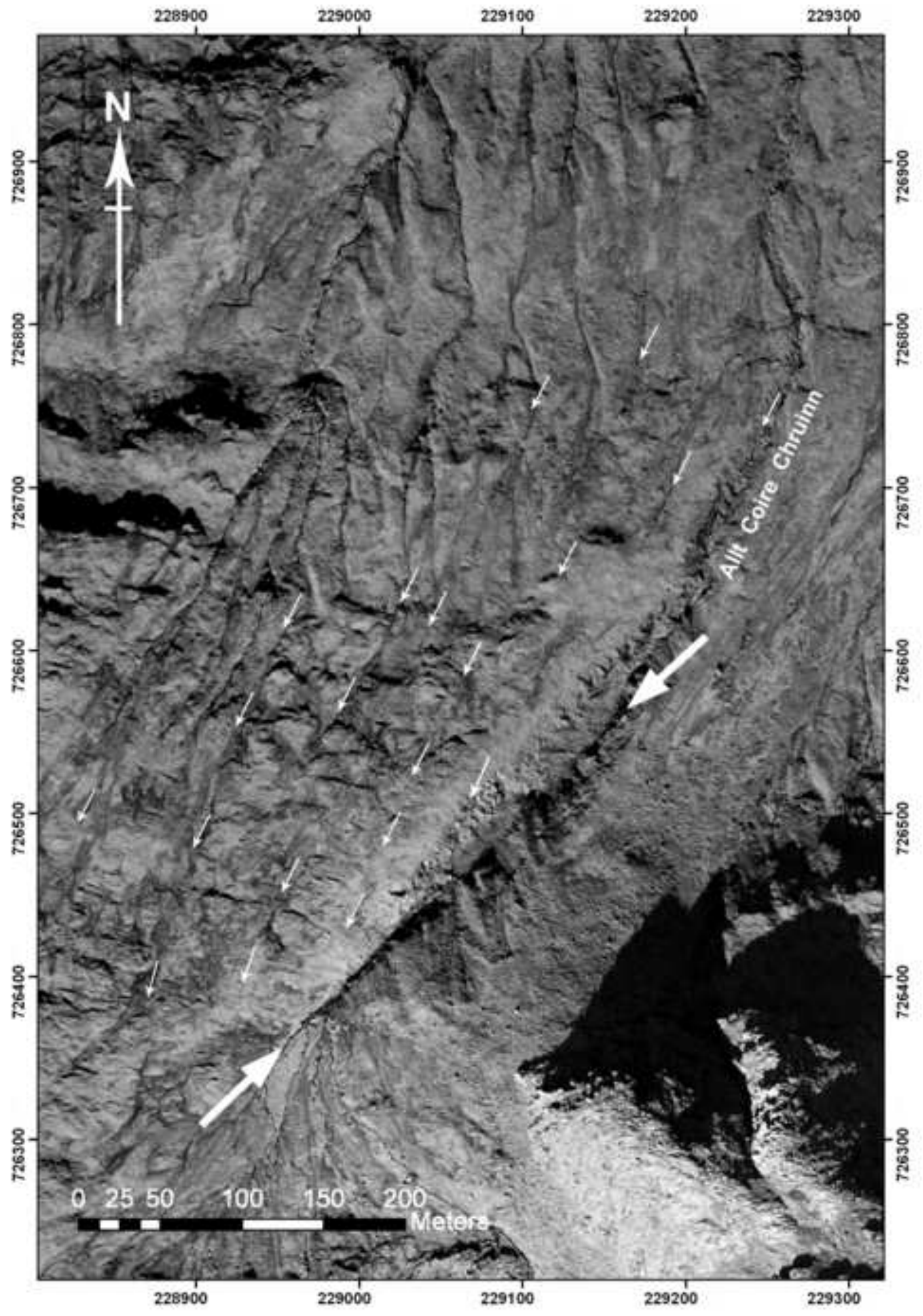

